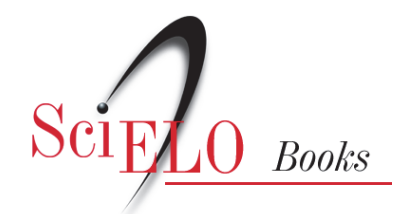

\title{
Estratégias de invenção do presente \\ a psicologia social no contemporâneo
}

Neuza Guareschi (org.)

GUARESCHI, N., org. Estratégias de invenção do presente: a psicologia social no contemporâneo [online]. Rio de Janeiro: Centro Edelstein de Pesquisas Sociais, 2008. 255 p. ISBN: 978-85-99662-908. Available from SciELO Books $<$ http://books.scielo.org $>$.

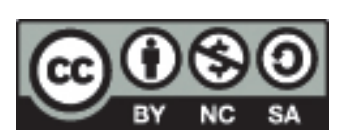

All the contents of this chapter, except where otherwise noted, is licensed under a Creative Commons Attribution-Non Commercial-ShareAlike 3.0 Unported.

Todo o conteúdo deste capítulo, exceto quando houver ressalva, é publicado sob a licença Creative Commons Atribuição Uso Não Comercial - Partilha nos Mesmos Termos 3.0 Não adaptada.

Todo el contenido de este capítulo, excepto donde se indique lo contrario, está bajo licencia de la licencia Creative Commons Reconocimento-NoComercial-CompartirIgual 3.0 Unported. 


\section{BIBLIOTECA VIRTUAL DE CIÊNCIAS HUMANAS}

\section{ESTRATÉGIAS DE INVENÇÃO}

\section{DO PRESENTE:}

a psicologia social no

\section{contemporâneo}

\section{Neuza Guareschi}

Organizadora

centro edelstein de pesquisas sociais 
Neuza Guareschi

Organizadora
Esta publicação é parte da Biblioteca Virtual de Ciências Humanas do Centro Edelstein de Pesquisas Sociais - www.bvce.org

Copyright (c) 2008, Neuza Guareschi

Copyright (c) 2008 desta edição on-line: Centro Edelstein de Pesquisas

Sociais

Ano da última edição: 2004

\section{Estratégias de invenção do presente: \\ a psicologia social no contemporâneo}

Nenhuma parte desta publicação pode ser reproduzida ou transmitida por qualquer meio de comunicação para uso comercial sem a permissão escrita dos proprietários dos direitos autorais. A publicação ou partes dela podem ser reproduzidas para propósito não-comercial na medida em que a origem da publicação, assim como seus autores, seja reconhecida.

ISBN 978-85-99662-90-8

Centro Edelstein de Pesquisas Sociais

www.centroedelstein.org.br

Rua Visconde de Pirajá, 330/1205

Ipanema - Rio de Janeiro - RJ

CEP: 22410-000. Brasi

Contato: bvce@centroedelstein.org.br
Rio de Janeiro

2008

Dintro edelstein de pesquisas sociais 


\section{SUMÁRIO}

Texto de abertura

Neuza Maria de Fátima Guareschi

\section{Conferência de abertura}

Coordenador: Jefferson Bernardes (UNISINOS)

La psicología social en la encrucijada postconstruccionista: historicidad, subjetividad, performatividad, acción.

Lupicinio Iñiguez (UAB - Espanha)

\section{Simpósio 1 - Tecnologias da Informação e da Comunicação e Modos} de Subjetivação .

Debatedor: Pedrinho A. Guareschi (PUCRS)

Coordenadora: Cleci Maraschin (UFRGS)

A comunicação como nova dimensão da produção de subjetividade.... 43 André Parente (UFRJ)

CIVITAS, a Cidade Viva: ou do espaço de invenção do educador na escola .................................................................................... 54 Margarete Axt (UFRGS)

Ser humano versus máquina: quem produz quem? Pedrinho A. Guareschi (PUCRS)

Simpósio 2 - Redes Solidárias, Autogestão e Solidariedade

Debatedora: Maria da Graça Jacques (UFRGS)

Coordenadora: Jaqueline Tittoni (UFRGS)

Redes solidárias, autogestão e solidariedade..... Peter Spink (PUCSP/FGVSP)

Um outro olhar sobre a inclusão social e o trabalho do educador .........93 Paulo Peixoto de Albuquerque (UNISINOS)

Redes solidárias, autogestão e solidariedade: o desafio da mudança social...... ... 103
Simpósio 3 - Estratégias de Resistência e Criação

Debatedor: Tânia Galli Fonseca (UFRGS)

Coordenador: Rosemarie Tschiedel (UNISINOS)

Estratégias de resistência e criação: ontem, hoje.. Cecília $M^{a}$ B. Coimbra (UFF)

Competência ética e estratégias de resistência Virgínia Kastrup (UFRJ)

Simpósio 4 - Cultura, Individualismo e Sociabilidade

Contemporânea.

Debatedor: Bader Sawaia (PUCSP)

Coordenador: Henrique Nardi (UFRGS)

Os devires da cidade-pandemônio..........

Carmen S. de Oliveira (UNISINOS)

O irredutível humano: Uma antologia da liberdade Bader Sawaia (PUCSP)

Simpósio 5 - A Cidade como Território de Criação.

Debatedor: Maria Regina Paradeda (PUCRS)

Coordenador: Nelson Rivero (UNISINOS)

Imagem e cidade: trilhas juvenis ..... Glória Diógenes (UFC)

Combates urbanos: a cidade como território de criação. Luis Antônio Baptista (UERJ)

Simpósio 6 - Violência e Direitos Humanos: Adolescentes em Conflito com a Lei

Debatedor: Carmen S. de Oliveira (UNISINOS)

Coordenador: Sinara P. Farjado (Com. DH A.L./RS)

A FEBEM e suas propostas socioeducativas baseadas na "Tropa de

Choque" e no "Choquinho".

Rosalina Carvalho da Silva (USP)

Maria da Graça Corrêa Jacques (UFRGS) 


\section{Simpósio 7 - Psicologia e Políticas Públicas: A Função Social do}

\section{Estado.} 197

Debatedor: Mary Jane Spink (PUCSP)

Coordenador: Helena Scarparo (PUCRS)

O drama da invisibilidade

Luiz Eduardo Soares (Secretário Nacional de Segurança)

\section{Palestras.}

Emergencia de las concepciones sociales en el movimiento cultural argentino de principios del siglo XX. Cristina Di Doménico

"Ter" ou "fazer" o gênero: O dilema das opções epistemológicas em Psicologia Social.

Maria da Conceição Nogueira

Sobre os Autores

\section{APRESENTAÇÃO}

Ao longo de sua trajetória, a ABRAPSO sempre se constituiu como um espaço de crítica e de invenção de estratégias de resistência às formas de assujeitamento que permeiam a sociedade contemporânea, assumindo um posicionamento ético, político e científico que ultrapassa as fronteiras disciplinares da Psicologia. É a luta pela afirmação da vida, pela legitimidade de diferença, pela responsabilidade ética das escolhas que têm marcado o compromisso da Psicologia Social com o seu tempo.

A temática deste congresso - Estratégias de invenção do presente: a Psicologia Social no contemporâneo - exprime essa trajetória na qual as múltiplas estratégias de resistência e criação encontram, na ABRAPSO, um território de interlocução e de interface entre saberes e fazeres.

A experiência do sujeito contemporâneo é a inspiração necessária tanto para a produção de conhecimento como para as propostas de intervenção em Psicologia Social. Resistir à cristalização das instituições, implicar-se nos rumos da história e inventar novos territórios existenciais são desafios aos quais temos sido convocados em nosso cotidiano.

As temáticas do XII Congresso Nacional da ABRAPSO estratégias de resistência e criação; redes solidárias, autogestão e sustentabilidade; psicologia e políticas públicas; a função social do Estado; tecnologias da informação e da comunicação e modos de subjetivação; cultura, individualismo e sociabilidade contemporânea; direitos humanos e a cidade como território de criação - visibilizam esses desafios e nos colocam como protagonistas do nosso tempo.

Direção Nacional da ABRAPSO Gestão 2001-2003 


\section{TEXTO DE ABERTURA}

\section{Encontro Nacional da ABRAPSO}

Neuza Maria de Fátima Guareschi

Desde sua fundação em 1980 a ABRAPSO promove a cada dois anos, um encontro nacional de Psicologia Social. O evento congrega a comunidade científica e profissionais que fazem da interface entre a Psicologia e a Sociedade seu campo de trabalho e de reflexão.

Ao longo de sua trajetória, a ABRAPSO sempre se constituiu como um espaço de crítica e de invenção de estratégias de resistência aos modos de assujeitamento que atravessam as formas de dominação características da sociedade contemporânea, assumindo um posicionamento político e científico que ultrapassa as fronteiras disciplinares da Psicologia. É a luta pela afirmação da vida, pela legitimidade da diferença, pela responsabilidade ética das escolhas que têm marcado o compromisso da Psicologia Social brasileira com o seu tempo.

Resistindo à cristalização de discursos hegemônicos, este encontro pretende implicar-se no cotidiano da história de modo a não somente refleti-la, mas inventá-la. Estamos iniciando um século marcado pela velocidade, pelo desenvolvimento tecnológico, pelo poder midiático, pelas violentas desigualdades sociais, pela exploração do medo e manutenção de relações de opressão em um mundo globalizado cada vez mais caracterizado pelo individualismo.

Diante desse contexto, a ABRAPSO assume o compromisso ético de ir além de uma mera exposição científica e acadêmica de trabalhos, pesquisas e ações realizadas no país, fazendo jus à própria trajetória crítica que caracteriza a sua história. Há de se desejar mais! Produzir um espaço e um tempo de resistência à volatilidade dos modos de viver deste tempo; lutar contra a ditadura da imagem descartável e instantânea e permitir que o corpo experimente seus movimentos de criação e desconstrução; confrontar-se com uma sociedade marcada pela mercantilização e privatização da subjetividade provocando experiências solidárias participativas.
A temática deste Congresso - Estratégias de invenção do presente: a Psicologia Social no contemporâneo - exprime essa trajetória da ABRAPSO e atualiza assim as múltiplas estratégias de resistência e criação, que encontram neste espaço um território de interlocução e de interface entre saberes e fazeres, que tem na experiência do sujeito de hoje a inspiração reflexiva necessária tanto à produção de conhecimento, como às propostas de intervenção que caracterizam a Psicologia Social no presente.

Buscamos movimentos de construção da Psicologia como uma ação política e social, como um conhecimento que produz diferenças e não somente as acomoda, que pretende experimentar a potência do múltiplo. Como forma de abordar a complexidade deste momento, temos que buscar ações positivas e afirmativas que possam inventar novos modos de existência.

Enfatizamos o processo de constituição de redes e iniciativas de diferentes segmentos da sociedade que objetivem organizações substitutivas às hegemonias que configuram o regime neoliberal, apagador de diferenças e padronizador da subjetividade. Para tanto, precisamos contemplar iniciativas que compreendam o intersubjetivo, a discussão e a problematização de novas tecnologias e modelos alternativos de sustentabilidade, nas diversas instâncias e extratos da coletividade.

Uma das premissas para a construção da cidadania é o debate sobre a efetivação dos direitos sociais e o acesso de todos aos mesmos. A proteção da vida humana é responsabilidade social sendo que as políticas sociais públicas delineiam os limites para minimizar a precarização da existência e da desigualdade, avançando na conquista de direitos universais, evidenciando a priorização da vida e da ampliação de sua qualidade.

Para isso é preciso transformar a própria ecologia social no contemporâneo, já que os modos de subjetivação atuais tendem a produzir formas perversas de individualismo. A Psicologia Social, a partir de uma perspectiva ética e estética, visa promover transformações socioeconômicas e culturais que se situam ao lado dos sujeitos na sua potencialidade no que se refere a outras formas de trabalho, de sexualidade, de posições de poder dos homens, das mulheres, das etnias, do lugar das crianças, dos jovens e dos velhos na sociedade. 
A cidade enquanto território de produção do viver e de sentir é o palco de subjetividades forjadas na relação dos corpos com seu espaço arquitetônico, suas vias de acesso e suas inacessibilidades, seus visíveis e invisíveis roteiros de passagem.

O grande número de inscrições e de trabalhos para este Encontro denota a riqueza e a pluralidade das práticas sociais experimentadas na contemporaneidade. $\mathrm{O}$ exame dos temas abordados pelos participantes evidencia o engendramento da diferença e a necessidade de criação em um movimento de crítica permanente do contexto social e político brasileiro. Um volume tão grande de trabalhos confere maior visibilidade à necessidade de estabelecimento de redes de comunicações que partilhem a riqueza e a diversidade de intervenções e reflexões possíveis em Psicologia Social.

Deste modo, as ideias e discussões apresentadas no Encontro, muitas das quais neste livro reproduzidas, nos dão a oportunidade de conhecer invenções advindas das práticas do cotidiano, dos desafios presentes na adversidade, das alegrias e do inusitado com o qual o viver nos brinda, tecendo sentidos, modos de ser e de estar no mundo. Como disse Nietzsche (1997) somos condenados a inventar e, quem sabe, talvez mesmo a descobrir. Este Encontro nos oportunizou momentos privilegiados para isto. Que estes espaços conquistados ao longo de toda a história da ABRAPSO representem a ampliação dos territórios emancipatórios da Psicologia Social Brasileira no que se refere à produção de conhecimento, à reflexão crítica sobre as práticas da psicologia e à participação efetiva na construção da história do país.

Texto proferido por Neuza Maria de Fátima Guareschi Presidente Nacional da ABRAPSO

\section{CONFERÊNCIA DE ABERTURA}

Coordenador: Jefferson Bernardes (UNISINOS)

\section{La psicología social en la encrucijada post-construccionista: historicidad, subjetividad, performatividad, acción}

Lupicinio Iñiguez

El construccionismo disuelve la dicotomía sujeto-objeto afirmando que ninguna de estas dos entidades existe propiamente con independencia de la otra, y que no da lugar a pensarlas como entidades separadas, cuestionando así el propio concepto de objetividad. De hecho, el construccionismo se presenta como una postura fuertemente des-reificante, des-naturalizante, y desesencializante, que radicaliza al máximo tanto la naturaleza social de nuestro mundo, como la historicidad de nuestras prácticas y de nuestra existencia. Desde esta perspectiva, el sujeto, el objeto y el conocimiento, se agotan plenamente en su existencia sin remitir a ninguna esencia de la que dicha existencia constituiría una manifestación particular, como tampoco remiten a ninguna estabilidad subyacente de la que constituirían una simple expresión particular. En definitiva, el carácter literalmente construido del sujeto, del objeto y del conocimiento arranca estas entidades fuera de un supuesto mundo de objetos naturales que vendrían dados de una vez por todas (Ibáñez. 1994. p.250).

He aquí las bases del programa socio-construccionista. En los ochenta, este tipo de perspectiva penetra en el conjunto de las Ciencias sociales y, específicamente, en la Psicología social y se convierte en revulsivo en un contexto disciplinar marcado por una ortodoxia heredera del positivismo. Encuentra una fuerte oposición y las voces en contra se alzan potentes y descalificadoras, llegando a la amenaza de exclusión, cuando no a la exclusión misma, de todas aquellas personas que se sentían atraídas por este programa.

La cuestión ahora es, después de más de veinte años, ¿aún mantiene el construccionismo la misma carga de rebeldía? O por el contrario ¿estamos delante de una nueva forma de ortodoxia? Y si éste fuera el caso, 
¿comportará la ejecución de similares políticas de exclusión con los disidentes?

Aquello de lo que quiero hablarles es precisamente del construccionismo mismo para aventurar algunas de las claves que, a mi juicio, se encuentran en el paisaje post-construccionista una vez sentidos algunos desasosiegos, algunos malestares, algunos problemas incluso que pueden derivarse de la "época dorada" construccionista.

Mantendré, sin embargo, algunos puntos de anclaje relacionados con la voluntad de mantener en permanencia una perspectiva crítica en Psicología social. Perspectiva crítica en lo teórico, pero también el estudio específico de procesos sociales y, por qué no también, en la intervención. Lo que me gustaría es perfilar un panorama dónde aún tengan cabida aportaciones que subviertan el carácter instituido y objetivo de las ciencias sociales partiendo del posicionamiento de que la autoridad científica es, en estos momentos, la autoridad con mayor poder a la hora de justificar el mantenimiento de un orden social, de legitimar órdenes sociales con efectos de sujeción y dominación de las personas.

\section{El punto de vista socio-construccionista}

Creo honestamente que nunca ha estado demasiado claro, sobretodo entre sus críticos, qué es o en qué consiste eso que se llama "construccionismo", La crítica fácil, que ha dominado desde el inicio, lo ridiculiza desde la estrambótica idea de que su esencia misma no es sólo que afirme que todo es una construcción social, sino, sobretodo, que es una construcción linguiística. Tal ridiculización utiliza como tropo retórico la celebrada idea de que los/as construccionistas desatienden las limitaciones y constricciones que impone la realidad material.

Pero el construccionismo, o mejor - para no reificar - la perspectiva construccionista no es exactamente eso. Lo que quiero decir es que al decir esto, el sufijo "ismo" tiene el efecto discursivo de reificar un proceso, haciendo aparecer algo como una "escuela" de pensamiento, o una "nueva teoría". Esta perspectiva es algo más complejo, con bastantes más matices que convendría señalar y tener en cuenta. A pesar de ello, es bien cierto que no se puede ofrecer una definición única de "construccionismo social". Mas bien, se pueden detallar ciertos elementos y supuestos que, vistos en conjunto, podrían representar esa "perspectiva", o como ha dicho Tomás Ibáñez (1994) ese "movimiento".

Los elementos y supuestos de esta "perspectiva" o "movimiento" constituyen una amplia y abierta lista. Y, además, contra 1o que se puede suponer a partir de las críticas "desde fuera", nada homogénea pues como dice Vivian Burr (1997), no se puede afirmar que haya ningún elemento sine qua non que determine la adscripción de un autor o autora al "construccionismo social".

Sin embargo, están bastante claros los antecedentes donde enraizar esta perspectiva. Por parte de la Sociología, las influencias más notables han sido el Interaccionismo Simbólico (Mead, 1934). La Etnometodología (Garfinkel, 1967; Heritage, 1984) y, sin duda, el impactante trabajo de Peter Berger y Thomas Luckmann (1967) "La construcción social de la realidad". Por parte de la Psicología, el trabajo originario principal ha sido sin duda el de Kenneth Gergen (1973) "La Psicología Social como Historia" al que se suman otras obras producidas en el contexto de la "crisis de la psicología social" como la de Nigel Armistead (1974), Y algunas posteriores como la de Jerome Bruner (1990), entre otras.

El conjunto de obras y autores/as es, al día de hoy, amplísima. Sólo por citar algunas obras más significativas, habría que aludir a: Kenneth Gergen (1991, 1994), Rom Harré (1986), Julian Henriques, Wendy Holway, Cathy Urwine, Couze Venn y Valerie Walkerdine (1984), Celia Kitzinger (1987), Tomás Ibáñez (1989, 1990, 1994, 1996), Ian Parker (1998), Ian Parker y John Shoter (1990), Nikolas Rose (1989, 1996), John Shotter (1993). En el caso de desarrollos específicos no se pueden olvidar las obras producidas en el marco de los estudios sociales de la ciencia: Bruno Latour (1987), Bruno Latour y Steve Woolgar (1986), Karen Knorr-Cetina (1996). Ni lo que podemos llamar el "construccionismo práctico" y su posterior desarrollo conocido como "psicología discursiva": Michael Billig (1987), Derek Edwards (1997), Derek Edwards y Jonathan Potter (1992), Jonathan Potter (1996), Jonathan Potter y Margaret Wetherell (1987).

Si hay algo que se pueda identificar como característica principal, ésta sin duda es su posición crítica, su posición de continuo cuestionamiento de aquello que venimos considerando como obvio, correcto, natural o evidente. En palabras de Edward E. Sampson (1986, 
p.37) “todo es sospechoso mientras no haya más información”. Lo que, como dice Tomás Ibáñez (1994, p.276) “(...) obliga a vivir peligrosamente, bajo la constante tensión de tener que revisar sin tregua las seguridades que se alcanzan".

\section{Elementos para una posición construccionista}

Es ya un lugar común decir que el mundo es una "construcción social", o que las personas son "construcciones sociales". En definitiva, que todo es una "construcción social”. Para no caer en esta simplificación en la que confortablemente han concluido muchas lecturas del "construccionismo social", veamos algunos elementos que marcan y definen un talante construccionista.

\section{a) Antiesencialismo}

Las personas y el mundo social somos el resultado, el producto, de procesos sociales específicos. Esto implica que ni las personas ni el mundo "tienen" una naturaleza determinada. La consecuencia de ello es, por tanto, la de mantener un marcado antiesencialismo. No existen objetos naturales, los objetos son lo que son porque los hacemos, y nosotros somos tan dependientes de ellos, como ellos de nosotros. La noción de objeto es una convención social y por consiguiente, dependiente de la definición que hacemos de él. No hay pues objetos "naturales" que existan 'en la realidad' de forma independiente, más bien son objetivaciones resultantes de prácticas sociales que los han cinstituido como tales (Ibáñez, 1994). La misma idea se aplica a los objetos psicológicos en el sentido de que no provienen de una supuesta 'naturaleza humana', sino que son también resultado de prácticas de objetivación.

\section{b) Relativismo/Antirrealismo}

Un punto de vista construccionista Implica la negación de la relación entre el conocimiento y la percepción directa de la realidad, en el sentido de que la "Realidad" es sólo un conjunto de versiones construidas colectivamente en el seno de las distintas sociedades y culturas a lo largo de la historia como comunidad. La "Realidad" no existe con independencia del conocimiento que producimos sobre ella o con independencia de cualquier descripción que hagamos de ella (Rorty, 1979). En consecuencia, es en ese sentido en el decimos que construimos la realidad y que lo que decimos acerca de ella es una cuestión de convenciones. No hay entonces separación entre la realidad y el conocimiento producido sobre ella. El objeto no genera su representación sino que resulta construido por nuestras prácticas (Ibáñez, 1994).

Esta perspectiva es, por tanto, relativista, aunque al decir esto se estimule la mayor de las desconfianzas y los recelos. Pero el relativismo también ha sufrido una potente estereotipación y desvirtualización, por lo que se ha de afirmar que adoptar una postura relativista no supone ubicarse del lado de la indiferencia hacia los otros o del idealismo más ramplón (Ibáñez, 2001). Como dice Tomás Ibáñez,

el relativista no suele tener problemas en su vida cotidiana con la realidad, no le molesta considerar que hay cosas que son reales, tampoco suele tener problemas con la verdad, no duda en afirmar qué es verdad y que si atraviesa la calle justo cuando pasa un coche puede ocurrirle algo. El relativista no tiene problemas con las conceptualizaciones pragmáticas de la realidad y de la verdad. La realidad y la verdad son creencias indispensables para la vida cotidiana, pero no quieren un estatus transcendente, objetivo y absoluto, les basta un estatus de "ir por casa", es decir simplemente humano (Ibáñez, 1996, p.87).

\section{c) Cuestionamiento de las verdades generalmente aceptadas}

La perspectiva construccionista se caracteriza también por el continuo cuestionamiento de la "verdad", poniendo en duda sistemáticamente el modo cómo hemos aprendido a mirar el mundo y a mirarnos a nosotros mismos. Esta perspectiva cuestiona a idea de que el conocimiento se base en la observación objetiva e imparcial de la realidad. Como sostiene Kenneth Gergen (1999) el construccionismo social deposita en las relaciones conjuntas el sentido que los seres humanos damos a la verdad, a lo que está bien o mal, a lo que es bueno o mal, a lo que se puede afirmar que,

lo que es "obviamente verdad y bueno" para una comunidad es frecuentemente fraudulento o moralmente repugnante para otra. En 
este sentido el construccionismo invita a una continua postura de autorreflexión - incluso de mirar hacia uno mismo. Cada palabra, proposición o propuesta debe ser provisional, abierta a la deconstrucción y a la evaluación político-moral (Gergen, 1999, p.221).

\section{d) Determinación cultural e historicidad del conocimiento}

Toda concepción del mundo o de lo social, es social y culturalmente dependiente. Las formas de categorización y conceptualización son específicas de cada cultura y cada momento histórico concreto. Y esta es una afirmación que se aplica no sólo al conocimiento 'común', sino también al 'conocimiento científico'.

Afirmar que "lo social" es histórico significa que las prácticas sociales producen conocimiento y construyen la realidad social. Al tiempo, ver la producción de conocimiento como práctica social implica que el conocimiento científico posee un carácter histórico, esto es, que se constituye mediante prácticas sociales como cualquier otra forma de saber. De ello se puede extraer la consecuencia de que los fenómenos sociales poseen un carácter procesual, lo que deja fuera la dicotomía 'producto' el fenómeno considerado como producto en el momento de analizarlo'proceso' - que sustentaría el producto.

El tijeretazo que se da al tiempo permite tratar un fenómeno social como si fuera un "objeto" estable, un "producto" o una "cosa" con lo cual se satisface obviamente a las exigencias del ideal e inteligibilidad positivista, pero al mismo tiempo se cambia irremediablemente la naturaleza, o la identidad del fenómeno investigado (Ibáñez, 1994, p.230).

Así pues, desde un punto de vista histórico y cultural, no hay nada absoluto, ningún saber es verdadero ni definitivo. Las distintas concepciones del mundo son dependientes de su contexto cultural e histórico, es decir, que toda forma de conocimiento en una cultura concreta y en una época histórica dada, es peculiar y particular.

\section{e) El lenguaje, condición de posibilidad}

La realidad se construye socialmente y los instrumentos con los que se construye son discursivos. Esto se puede afirmar porque el lenguaje no sólo es referencial, si no que es, fundamentalmente, de naturaleza formativa (Shotter, 1987, 1993a y b). El lenguaje no es únicamente expresivo o referencial sino una forma de acción mediante la cual construimos el mundo.

La capacidad preformativa del lenguaje implica, entre otras cosas, que nuestras concepciones del mundo no tienen su origen en la "realidad objetiva" sino en las variadas interacciones que las personas realizamos cada día, así como en las que mantuvieron quienes nos antecedieron en el tiempo. Cuando "llegamos al mundo", el entramado, las estructuras y las categorías conceptuales propios de nuestra cultura ya existen, y es precisamente durante el desarrollo de nuestra capacidad lingüística, y por medio de ella, cuando adquirimos estos conceptos socialmente elaborados.

De modo gráfico, todas las personas que forman parte de una comunidad lingüística, o que han formado parte de ella, contribuyen con cada acción e interacción desplegada en su vida cotidiana a elaborar y reproducir la estructura conceptual y los significados de susconcepciones sobre el mundo. El lenguaje es una condición previa de lo que llamamos pensamiento, ya sea individual o social (Gergen, 1994, 1999; Edwards y Potter, 1992).

\section{f) El conocimiento es una producción social}

El conocimiento, incluido el conocimiento científico, es el resultado de una construcción colectiva. Las prácticas cotidianas fabrican nuestro saber y nuestra concepción del mundo y de nosotras/os mismas/os. De entre las prácticas sociales, las más importantes son las discursivas.

En definitiva, el conocimiento científico tiene en común con el conocimiento sin otras adjetivaciones el hecho de nacer en el seno de la interacción social y de constituirse en el espacio de la intersubjetividad con base en las convenciones lingüísticas, a los presupuestos compartidos y a los diversos procedimientos para establecer un consenso que sólo es posible gracias a la existencia de 
un mundo de significados comunes. En consonancia con las aportaciones de la teoría crítica, el construccionismo destaca los diferentes intereses que guían las diversas racionalidades científicas y concluye a la inevítabilidad de que los conocimientos conlleven operaciones normativas y repercutan sobre la propia realidad social (Ibáñez, 1994, p.107).

La relación entre conocimiento y práctica social es una relación de influencia recíproca. Efectivamente, los saberes y el conocimiento sobre el mundo son resultado de la acción conjunta (Shotter, 1993a y b) Y dan lugar a formas diferentes histórica y culturalmente. Al mismo tiempo, cada conocimiento construido conjuntamente abre el campo de nuevas y diferentes formas de acción social. Cada saber, cada conocimiento social posibilita ciertos modos de acción social al tiempo que excluye otros.

\section{g) "Construcción social"}

Todo lo anterior delimita el campo de la "construcción social", no es pues una mera afirmación trivial o sin sentido.

Uno de los peligros de la perspectiva construccionista es convertir la noción de "construcción social" en algo de carácter estático y reificante, es decir, algo permanente y produciendo el mismo tipo de efecto que producen las cosas. Esta es una concepción estrecha y limitante de construcción social. Creo que aquí viene bien la contundente afirmación de Tomás Ibáñez:

(...) una construcción social no participa de la metáfora arquitectónica de un edificio que, una vez construido, se mantiene por sí solo. Lo socialmente construido no sólo ha sido construido por determinadas prácticas sociales, sino que esas prácticas lo mantienen de forma dinámica, incesantemente. Si cesan las prácticas, la construcción se esfuma (Ibáñez, 1996, p.67).

Las prácticas sociales crean estructuras, incluso instituciones, sociales pero igualmente las estructuras sociales inciden y ejercen una fuerte influencia sobre las prácticas. Toda práctica social entonces, aunque pequeña o insignificante, trivial o cotidiana, contribuye de manera directa a la construcción de lo social. Las estructuras e instituciones sociales constituidas constriñen, condicionan y enmarcan también dichas acciones e interacciones. Si no fuera así, basta pensar sólo un momento qué pasaría con nuestro mundo y nuestra vida si, por un instante, se paralizaran todas las acciones sociales, completamente. No hay pues mundo ni vida social sin la existencia de las prácticas que los constituyen de donde se muestra el enorme valor de su capacidad constitutiva.

\section{Mantener una perspectiva crítica}

Después de algún tiempo hemos podido caer en una cierta complacencia con el "ideario construccionista" convirtiéndolo en una especie de "nueva ortodoxia". Entiendo que un talante crítico debe huir de esta clase de complacencia. Ahora bien, antes de pasar a dibujar algunos elementos del nuevo paisaje "post-construccionista" me gustaría señalar algunas características que han sido útiles en la empresa construccionista y que creo pueden ser todavía útiles en el futuro. Son características que relacionadas con una forma de entender al ser humano que merecen ser tenidas en cuenta: la historicidad de nuestro conocimiento y el carácter interpretativo del ser humano.

\section{Extraer consecuencias del carácter histórico del conocimiento}

Ya he dicho, y esto puede relacionarse con el descalabro de la "fe positivista" y con la emergencia de nuevas perspectivas de tipo crítico, que las disciplinas científicas no son "productos naturales", sino mas bien el resultado de prácticas sociales, históricamente situadas y propias de una sociedad determinada. En este sentido tanto los fenómenos y procesos psicosociales como las elaboraciones acerca de ellos, son vistos como marcados ineludiblemente por la historicidad: "Interpretar un fenómeno social" implica explicar sus condiciones de constitución. Todo fenómeno social es depositario de memoria ya que está conformado en virtud de las relaciones sociales que lo han posibilitado, no sólo en cuanto a su correspondencia con un determinado periodo histórico o por as alteraciones producidas por el tiempo (...) Aceptar este planteamiento implica cuestionar la objetividad de los saberes psicosociales al restituirles su dimensión social (Gergen, 1982; Ibáñez, 1989) y no abandonarlos a la hipotética certidumbre de los hechos, que se presuponen como invariables, estables y no sometidos a ninguna contingencia” (Vázquez, 1998, p.68). 
La emergencia del interés por la historia es una de las huellas dejadas por la crisis de los paradigmas positivistas en las ciencias sociales y creo que es una herencia que convendría conservar. En el caso específico de la Psicología social, el artículo La psicología social como historia de Kenneth Gergen (1973) marcó un punto de inflexión en la comprensión de los procesos psicosociales. Este planteamiento vale para cualquier proceso social o psicosociales, pero señalaré específicamente la identidad como un caso ejemplar cuando se ha visto como un producto históricamente constituido: el individuo es un invento moderno, las ciencias que lo estudian también tienen su aparición en contextos socio-históricos concretos, y su inteligibilidad se hace imposible sin el recuerdo de esa historicidad (Foucault, 1975, 1990; Cabruja, 1994, 1996).

Asumir plenamente el sentido de la historicidad y que el papel de las ciencias y de sus objetos no se reduce a una propuesta de explicación lineal de la constitución del presente, abre la posibilidad de pensar el presente pero también la de construir futuros distintos:

En cada momento existen varios futuros posibles, de los que tan sólo uno se realizará. En esta medida se puede decir que, al igual que ocurre con el futuro, tampoco el pasado está "ya escrito" puesto que sus características se van actualizando en función de unos desarrollos posteriores concretos que no agotan, por definición, el conjunto de todos los desarrollos posibles. No es ya que el futuro dependa en parte del pasado, sino que el propio pasado adquiere algunas de sus características en función del futuro que efectivamente se realiza. De todos los "no acontecimientos" que están presentes en una situación dada, sólo se concretizarán aquellos que se puedan ver desde el futuro que efectivamente se ha realizado (Ibáñez, 1994, p.219).

De lo que se trata en definitiva es de admitir que la realidad posee un carácter procesual (Ibáñez 1989, Gergen 1973). Por tanto, no basta con decir "la realidad social" es histórica. Lo que hay que decir es que los fenómenos sociales no sólo son históricos porque cambian con el tiempo y porque son relativos al periodo en el que se manifiestan, sino porque son intrínsecamente históricos, es decir, que tienen memoria, y que lo que son resulta de la historia de su producción, de las peculiaridades de la cultura donde se producen, de sus tradiciones y del modo de vida de la sociedad (Ibáñez, 1994). El presente de cualquier fenómeno, personal, social, político, científico, no es independiente de su genealogía, o lo que es lo mismo, su forma actual resulta de las prácticas sociales y de las relaciones sociales que lo fueron constituyendo. El potencial de este punto de partida se ve en el trabajo de, entre otras, las corrientes post-estructuralistas, que vieron con claridad y asumieron en toda su magnitud, que no se puede dar cuenta satisfactoriamente de un fenómeno si no se dilucida también el proceso de su constitución. Los desarrollos de investigaciones genealógicas han demostrado también una gran capacidad de innovación y reflexión creativa respecto a lo que nos pasa, a nuestro presente.

Para el caso de la psicología social, la aceptación del carácter histórico del conocimiento implica que "el conocimiento que elabora la psicología social sobre sus objetos de estudio no es un conocimiento que cambia únicamente porque sea más preciso, más rico o más acertado, sino que es un conocimiento que también cambia porque cambian las características de los objetos sobre los que versa" (Ibáñez, 1989, p.110). Por ello, enfocar genealógicamente el estudio de un objeto de conocimiento nos permite comprender nuestro presente, resaltando al mismo tiempo que su repetición no es obligatoria en el futuro.

Es la historia, la tradición de una ciencia, la que fundamenta su andadura, la que orienta sus preguntas y la que confiere interés a sus elecciones y problemas. La idea de tradición que mantiene Hans-Georg Gadamer (1960), nos permite pensar que la tradición no sólo es la que encuadra nuestro pensamiento e interpretación de lo que ocurre, si no que es precisamente esa tradición la que posibilita cualquier lectura del mundo o de nosotros mismos.

\section{Subrayar el carácter interpretativo del ser humano}

Cualquier saber formulable, incluido el de las ciencias naturales, descansa sobre presupuestos hermenéuticos y sobre las preinterpretaciones inherentes al lenguaje (Gadamer, 1960; Ibáñez, 1990). La orientación hermenéutica ha revitalizado en el ámbito de la producción científica, la relevancia que poseen el lenguaje y los significados, teniendo en cuenta el contexto sociohistórico de su producción. La hermenéutica ha enfatizado la importancia de la comprensión y ha señalado, además, que el modo mismo de participación del ser humano en el mundo pasa irremediablemente por 
la comprensión (Gadamer, 1960). Ningún proceso social, y específicamente ni la Ciencia ni el sujeto pueden darse sin interpretación, pues nuestro conocimiento del mundo y de nosotros/as mismos/as está vinculado a la interpretación que realizamos desde el marco linguístico y cultural en el que nos desenvolvemos. No es posible entonces delimitar la objetividad del sujeto sin la interpretación y sin que medie el juego hermenéutico.

De entre las orientaciones hermenéuticas, la que siempre me ha atraído, y en la que me apoyaré, es la de Hans-Georg Gadamer (1960). Gadamer sostiene que toda interpretación es dependiente de sus condiciones socio-históricas de producción y de los anclajes culturales y lingüísticos del sistema de significados que la articulan. Una interpretación adquiere su significado en un contexto determinado, en un marco interpretativo al que ese significado se incorpora y que, para Gadamer (1960), está condicionado por nuestras preconcepciones. Estas "preconcepciones" son colectivas, históricas y culturales, porque dependen de la posición que el sujeto ocupa dentro de una tradición histórica y cultural específica. Esto las convierte en condiciones de posibilidad para interpretar y también el propio límite de la comprensión misma. Justamente esta idea de que no podemos sino interpretar a partir de una tradición histórica concreta en la que nos enclavamos, es la que resulta imprescindible desde mi punto de vista en el marco de una perspectiva crítica.

Para Gadamer la hermenéutica es la ontología del ser humano, es decir, como personas no tenemos otra forma de vivir que la de procesar y producir sentido, por lo que a partir de aquí es importante tener en cuenta cuáles nuestra producción de sentido sobre un objeto, en qué preconcepciones se apoya, cuáles son sus tradiciones y sus condiciones de producción.

Otros pensadores, con posterioridad al Gadamer, tales como Paul Ricoeur (1981) o Charles Taylor (1985), o sociólogos como Anthony Giddens $(1982,1984)$ han desarrollado diferentes líneas de la orientación hermenéutica. Específicamente, Charles Taylor (1985) ejerce una notable influencia por haber desarrollado una conceptualización del ser humano, no sólo como ‘animal hermenéutico' sino como ‘animal autointerpretativo'. Es decir, como un ser cuya naturaleza está constituida por las propias interpretaciones de sí mismo. Como sugiere Tomás Ibáñez (1994), la conceptualización de Taylor se presenta como ineludible para toda ciencia social que tome en cuenta la dimensión "irreductiblemente subjetiva" que presenta la experiencia humana, y que a su vez no desatienda las condiciones sociales de su emergencia en un contexto que va más allá de los significados compartidos y que se adentra en los significados comunes dentro de una comunidad.

\section{¿En qué se ha equivocado el construccionismo?}

Así dice Steve Brown en un artículo reciente (2002), refiriéndose a la Psicología social crítica que él coloca en su totalidad en la galaxia construccionista.

Posibles respuestas a esta pregunta se encuentran en los recientes debates sobre el construccionismo y las innumerables críticas publicadas en los últimos anos. Dejaré de lado aquellos debates centrados en la discusión sobre las implicaciones epistemológicas y ontológicas del construccionismo que se hayan generado desde posiciones que, en sentido corto, podemos llamar convencionales cuando no conservadoras (Greenwood. 1994; Hacking. 1998; Hibberd. 2001a, 2001b; Jenkins, 2001). También dejaré por el momento aquellas críticas surgidas desde una posición menos hostil (Liebrucks. 2001; Maze, 2001; Nightingale y Cromby. 1999; Velody y Williams. 1998), para centrarme a título ilustrativo, en la formulada por Steve Brown.

Él es considerablemente más duro que yo. Por un lado la acusa de haber asumido una especie de "retórica de la guerra", entre buenos y malos, donde los buenos serían los/as construccionistas y los malos/as la psicología social mainstream, y también de asumir, tomando una idea de Michel Serres (1990), una 'filosofía de la denuncia'. Ésta se caracteriza por el propósito de acusar y denunciar. Aquí la acusación y la denuncia sería la de ver a la Psicología social dominante como batallando contra la asimilación de las ciencias sociales con las ciencias naturales. Y le atribuye también el ser una especie de imagen especular de la Psicología social dominante, es decir, siguiendo la máxima de formular hipótesis que luego se han de contrastar empíricamente, por mas que en el tipo de contrastación y el tipo de instrumentación utilizada para ello, fueran diferentes. 
Finalmente cree que el construccionismo es una especie de teología, pues cuando quiere defenderse de la acusación de irresponsabilidad política o social, se sitúa en una posición maximalista al pretender que puede realizarse un juicio neutro a partir de una especie de "creencias puras".

No puede decirse que sean críticas sin sentido. Pero en buena medida surgen de una homogenización de posiciones construccionistas que ignora las diferencias y los matices que pueden identificarse dentro del movimiento. No es lo mismo el construccionismo realista de un Ian Parker o de un Rom Harré, que el construccionismo práctico de una Derek Edwards o un Jonathan Potter, por poner algún ejemplo. Lo que Brown ve como retórica belicista o filosofía de denuncia, podría ser alternativamente visto como práctica de resistencia ante la dominación; la presunta emulación del programa empiricista hipotético-deductivo, un ansia de mantener un anclaje en la vida cotidiana. La "teología construccionista" que Brown denucia, podría ser mas bien una nueva agenda política donde la desestabilización, sería una práctica de acción directa contra aquello dado por sentado.

¿Qué está entonces equivocado desde mi punto de vista? Probablemente la acritica acomodación a la paulatina institucionalización del construccionismo social. En efecto, de lo que no cabe la menor duda es que en tan solo dos décadas este movimiento ha pasado de ser un marginal en las ciencias sociales y en la Psicología social, para pasar a ser una perspectiva reconocible y reconocida, con sus propios medios de comunicación y difusión, recursos públicos para investigación, etc. Y a este proceso no se ha posicionado siempre de forma crítica y contundente sino, frecuentemente con un talante conformista y acomodaticio. Si hace 20 anos defender una tesis doctoral en este tipo de perspectiva era un acto heroico, hoy es, en algunos ámbitos, una marca de distinción y una garantía de promoción profesional y académica.

En el caso específico de la Psicología social, una equivocación también ha sido un excesivo ánimo y práctica proselitistas. En efecto, la “colonización”, el enrolamiento de personas, grupos, ámbitos y temas de investigación, posiciones académicas y de medios de difusión, se ha hecho con un ánimo casi misionero que ha conseguido expandir efectivamente al movimiento, pero al precio de hacer incluir en su seno cualquier clase de cosa, planteamiento o perspectiva sólo por el hecho de ser "marginal", atípica o, incluso, estrambótica. Ello ha contribuido innegablemente a perder atención por el detalle, a los matices y, con frecuencia también, al necesario tempo de la reflexión seria, al debate constante, a la acción contra la dominación entendida como homogeneización. Así mismo la amalgama de orientaciones y posiciones que hoy en día se engloba en el movimiento está creando una situación de conflicto de no fácil resolución.

¿Qué hacer? Una posibilidad sería abandonar y como se dice en España "echarse otra vez al monte", volverse en contra suya y trabajar por nuevas formas de pensamiento y acción críticas y emancipadoras que permitan de nuevo gestar un revulsivo y una alternativa al conocimiento instituido. En este tipo de salida, Tomás Ibáñez ve un peligro, a saber, que muchos/as de los que no pudieron soportar la emergencia de los plateamientos construccionistas se conviertan en aliados ahora:

estos son los aliados junto a los cuales nunca habría que caminar, porque si se trata de emprender en algún momento el desmantelamiento del socio-construccionismo, será para construir con nuevas propuestas y con algunos de sus restos un nuevo movimiento que extreme los impulsos iniciales que le animaros y consiga proyectarlos más lejos de lo que él mismo supo hacer (Ibáñez, 2003).

Mientras se decide qué hacer, pueden lanzarse algunas propuestas. Desde mi punto de vista, algunos supuestos constitutivos del construccionismo pueden mantenerse. Otros deben atender a las críticas que se le han hecho en los últimos anos. Pueden asumirse perspectivas nuevas. Y, finalmente, puede re-hacerse la agenda política para adaptarla a los nuevos desafíos que plantea las nuevas formas de estructuración y organización social y contribuir a la construcción de un mundo mas justo y mas igualitario.

\section{Aperturas y efervescencias. Elementos de tránsito hacia un paisaje post-construccionista}

No debemos asumir una posición complaciente sólo con la contextualización histórico-cultural de la producción del conocimiento, la asunción el carácter interpretativo de los seres humanos, o los principios que sustentan una perspectiva construccionista. Asumirlos, pero también 
eventualmente criticarlos, es lo que nos permitirá sustentar en permanencia una perspectiva crítica en Ciencias sociales y, específicamente, en Psicología social. En los últimos anos, cuestionamientos, ideas nuevas, propuestas distintas, así como nuevas prácticas están ejerciendo una influencia enorme en las nuevas formas de pensar. Nos referiremos aquí a la reflexividad, cuyo desarrollo conceptual más importante se lo debemos a la sociología del conocimiento científico, a la Actor Network Theory (ANT), que traduciré como "teoría de la actriz-red, a la epistemología feminista y a la noción de performatividad.

\section{La reflexividad como característica de la producción de conocimiento}

"Reflexividad" es un concepto crucial en toda práctica de producción de conocimiento científico. Jonathan Potter la define así: "la reflexividad se refiere a un conjunto de cuestiones que se plantean cuando consideramos la relación existente entre contenido de una investigación y los escritos y las acciones de los investigadores" (Potter, 1996, p.286) Ahora bien, la reflexividad se ha entendido, dentro de este significado compartido, con matices diversos. Para la Etnometodología, por ejemplo, la reflexividad tiene que ver con las descripciones de una situación y con su construcción, en el sentido de que describir una situación es construirla, algo que tiene que ver simultáneamente con la comprensión de aquello que acontece y con la explicitación de esa comprensión. En palabras de Harold Garfinkel (1967, p.1), significa "que las actividades realizadas por los miembros para producir y manejar las situaciones de su vida organizada de todos los días son idénticas a los procedimientos utilizados para hacer descriptibles dichas situaciones".

La Sociología del Conocimiento Científico ha señalado las consecuencias que comporta considerar que no son sólo los hechos quienes están construidos socialmente, sino que la descripción de los modos en que se produce la factualidad, así como sus descripciones, son ellos mismos construcciones sociales (Ashmore, 1989).

Desde un talante construccionista, la reflexividad es vista como la capacidad de los seres humanos de "romper la disyunción objeto/sujeto" (Ibáñez, 1994). Esta capacidad hace posible que las personas sean capaces de verse a sí mismas como objeto de análisis, lo que ha abierto la posibilidad de construir el mundo de los significados compartidos y la intersubjetividad, condiciones necesarias para la constitución de "lo social".

El sentido que le daría aquí, no obstante, parte de la constatación de que la reflexividad o práctica reflexiva consiste en hacer "objetivable" el conocimiento (dimensión racional-epistemológica), y a la vez es una forma de resistencia a discursos dominantes en el conocimiento psico-social (dimensión ético-política). En efecto, durante mucho tiempo se ha mantenido en la ciencia y el conocimiento científico la creencia de que el/a científico/a era claramente diferenciado de su objeto de investigación (y lo mismo vale para el/a persona que interviene y la intervención). Ello permitía garantías de objetividad y validez a su producción ya que, de alguna manera, no se producía la "contaminación" entre la subjetividad humana y los fenómenos del mundo. Sin embargo, con una mirada con talante construccionista y crítico, la realidad no puede ser "representada" sino tan sólo aprehendida a través de descripciones sobre ella que hacemos tanto los/as científicos/ as como cualquier persona en su actividad cotidiana. Así pues, si abogamos por el rigor y la honestidad de nuestro trabajo como productores/as de conocimiento, es decir, como científicos/as, nos vemos obligados a volver la mirada hacia nuestras propias prácticas como científicos o investigadores. Son esas prácticas las que construyen y configuran no una realidad, sino una aproximación, versiones a las que llamamos "realidades", pero sabiendo que son formas ficcionadas, construidas por nosotras/os en nuestro ejercicio de investigar o intervenir sobre los fenómenos sociales.

Así pues, como investigadoras/es nos convertimos además en objeto de nuestra investigación, o lo que sería lo mismo, "nos objetivamos" frente al mundo y frente a determinados auditorios al tomar conciencia de las determinaciones socio-históricas en la construcción de categorías sociales, pensamientos y percepción de los principios con que representamos el mundo.

En el proceso reflexivo emergen otra consideración: el/a investigador/a lo es en la medida en que se relaciona con objetos y sujetos en su actividad, y lo que surge en esa relación es un producto que si en parte está predeterminado por la naturaleza de los objetos y sujetos sociales 
(construcciones socio-históricas), tiene un componente impredictible y creativo, producto de elementos contingentes, indexicales y circunstanciales del contexto donde acontece la acción. Esto permite modificar el conocimiento de los objetos (en el transcurso que va desde su presentación hasta después de mantener una relación con ellos) y permite que como investigadores podamos modificarnos e ir cambiando, es decir, tengamos una capacidad de agencia, o lo que es lo mismo, el poder de utilizar otras posiciones y elementos intersubjetivos de definición y acción que movilicen otros discursos y que anulen ciertas categorías socialmente predominantes. Ibáñez:

Las implicaciones políticas resultan obvias. Como dice Tomás

El psicólogo social se encuentra en la necesidad de interrogar permanentemente los conocimientos que produce para saber cuáles son las formas sociales que contribuye a reforzar o a subvertir y para saber en definitiva cuáles son los intereses a que está sirviendo (Ibáñez. 1989. p.115).

Pero puede decirse que la reflexividad así entendida, asume otra vez un dualismo esencial y esencialista entre la acción humana y el mundo natural, entre lo humano y lo no humano. Pero la agencia puede ser vista de otro modo, no solo desnaturalizando la acción del sujeto (tarea que el socio-construccionismo desarrolló muy competentemente) sino desocializando la agencia misma sin naturalizarla. Aquí los planteamientos de la teoría de la actriz-red (ANT) nos ayudarán en esa de-re-construcción.

\section{La teoría de la actriz-red (Actor network theory)}

La teoría de la actriz-red ha reconocido el valor positivo de las aportaciones del socio-construccionismo pero argumenta que ha comportando como efecto un "esencialismo social" que ha asumido de forma acrítica la dicotomía natural/social, humano/no-humano y la separación de lo natural por un lado y lo social por otro (Doménech, 1998). Atribuye también al socio-construccionismo desatención a cuestiones como las relativas a en qué consiste exactamente lo social, cuál es le papel de las ciencias en su constitución y por qué ha devenido objeto de estudio y conocimiento. Es precisamente la teoría de la actriz-red, gestada en el seno de los estudios sociales de la ciencia y la tecnología, de la mano de Bruno Latour, Michel Callon, John Law, entre otros (Callon, 1992; Callon y Law, 1982; Latour,199la, 1991b, 1991c; Law, 1987; LawyHassard, 1999). De la amplia gama de propuestas de la ANT, señalaré tres, las más pertinentes para el argumento: el principio de simetría generalizado, el recurso a la semiótica y la noción de cuasi-objeto.

El principio de simetría establece que se han de explicar en los mismos términos naturaleza y sociedad (Latour, 1991a). La propuesta es, por un lado, convertir en objeto de investigación empírica, por ejemplo mirando en las prácticas de los propios científicos, cuestiones que hasta ahora eran tratadas epistemológicamente, y por otro, abstenerse de dar por sentado aquello que los actores estudian y someten a escrutinio.

Es decir, como primera exigencia, entrar en los contenidos. Pero no para presentar la ciencia como producto, sino para mostrar cómo ésta se elabora y, por tanto, centrándose en la práctica de los científicos mientras éstos las llevan a cabo. Como segunda exigencia, prevenirse de utilizar explicaciones que se basen en dualismos que se toman como dados, sin cuestionarse, como la distinción verdadero-falso o la distinción naturaleza-sociedad(...) Una vez que se asume el modelo de explicación simétrica, lo que antes aparecían como cuasas (la sociedad, la naturaleza) son ahora las consecuencias, el efecto de complejas negociaciones, alianzas y contra-alianzas que forman parte de la actividad de los científicos, vista ésta, ahora, bajo el prisma de una concepción estratégica (Domenech, 1998, p.36).

El recurso a la semiótica. La ANT ve el discurso como un mediador entre la naturaleza y la sociedad. En ese sentido, la esfera del sentido es relativamente autónoma, concepción que le permite escapar de toda naturalización o sociologización abriendo un campo para situar entidades híbridas. Desta concepción semiótica se deriva la noción de actante. Actantes son seres o cosas que participan en un proceso de cualquier modo. La semiótica es en la ANT una caja de herramientas para rastrear las huellas del lenguaje e indagar sobre el modo en que se construye el significado, considerando que esa construcción deviene de la del orden y la construcción de caminos y que en ella pueden intervenir dispositivos, máquinas, cuerpos, textos, etc. 
Cuasi-objetos y cuasi-sujetos. El principio de la simetría generalizada implica que ya no se pueden considerar a la naturaleza o a la sociedad como principios últimos que den sentido a la realidad. Por ello, apela a objetos híbridos que no ajustan a conceptos clásicos como objeto, texto, sujeto y otros equivalentes, se trata de los cuasi-objetos y cuasisujetos. La idea fue extraída por Bruno Latour del trabajo de Michel Serres (1980). Estas entidades son a la vez naturales, sociales y discursivas. No son objetos ni sujetos pero su acción tiene efectos, marcan, determinan, configuran entramados de conexiones:

Radicalizar el principio de simetría significa para Callon y Latour hablar de entidades que toman su forma, significado y atributos como resultado de sus relaciones con otras entidades. En este razonamiento, las entidades, sean éstas las que sean, actores humanos o agentes no humanos, no tienen cualidades inherentes, no poseen esencias. Dualismos como los arriba mencionados, pasan de ejes articuladores de cualquier razonamiento sobre el mundo que nos rodea a meros efectos o productos, y pierden su papel de parámetros inmutables e indiscutibles en el orden de las cosas. Radicalizar el principio de simetría sobre el telón de fondeo de la semiótica, implica conceptuar las entidades sociales y naturales que pueblan nuestra vieja realidad como construcciones, como producciones o emergencias de redes heterogéneas, de entramados compuestos por materiales diversos cuya principal característica es precisamente esta heterogeneidad que se da entre ellos (Domenech y Tirado, 1998, pp.24-25).

La noción de cuasi-objeto y cuasi-sujeto definen a su vez la de actorred. Un actor-red es un cuasi-objeto que interconecta elementos heterogéneos $\mathrm{o}$, incluso, una red capaz de transformar y redefinir los constituyentes mismos de la red. Es un conjunto de interacciones heterogéneas con la propiedad de transformar tanto las interacciones como a quienes participan en ellas.

En el nuevo panorama post-construccionista la ANT nos descubre las implicaciones que el dualismo natural-social tiene y nos abre un campo nuevo de posibilidades de conceptualización de agentes, sujetos u objetos. Entre otras, nos permite equilibrar el balance entre lo natural-social recolocando lo material y creando una nueva hibridación conceptual alejada de esencialismos culturalistas o materialistas. Por otra parte, nos permite re-definir la agencia.

En efecto, la agencia que, como he señalado, ha sido vista como la propiedad definitoria de los seres humanos, pasa a ser vista como una acción no teleológica ni contingente a la intencionalidad interna de los sujetos, sean estos sociales o individuales, sino emergente en el entramado de interacciones entre actantes híbridos en el sentido de los actores-redes.

En esta misma línea de reivindicación de una semiología de lo material, también se ha señalado la importancia de tener en cuenta los objetos y las cosas como elementos participantes en la construcción de lo simbólico, que está dando lugar a lo que podríamos llamar una 'psicología social de los objetos'. No voy a entretenerme ahora en ello, pero una presentación de esta propuesta puede encontrarse en Miquel Doménech, Lupicinio Iñiguez y Francisco Tirado (2003).

\section{Posicionamientos: las consecuencias de la epistemología feminista}

El escenario atual de las Ciencias sociales y humanas no sería lo que es sin las aportaciones de la epistemología feminista. Ha cuestionado y puesto de manifiesto la relación íntima e inextricable existente entre un sujeto que percibe y aborda la comprensión de un objeto, y el objeto concreto sobre el que enfoca su mirada.

La epistemología feminista ha enfatizado que toda mirada, es una parte productora del objeto que se ve, y la ciencia no escapa a ello. De este modo, las epistemólogas feminista han documentado "fallos" en diseños de investigación y han probado la operatividad de determinados prejuicios en la selección y definición de los problemas de estudio científico, así como en la interpretación de los datos que arroja, esta perspectiva ha evidenciado que el sujeto, la comprensión que pone en marcha y el objeto, tanto en su percepción inicial como en su resultante tras el utillaje comprensivo, no son ni pueden ser neutros. Específicamente, la epistemología feminista se ha centrado en poner de manifiesto los sesgos de tipo patriarcal y sexista de la "mirada" científica, dirigiéndose a hacernos notar tanto su reflejo en las diversas epistemologías utilizadas para abordar el conocimiento de un objeto, como también esforzándose en que podamos evidenciar que la presencia de esos sesgos atraviesa el propio objeto de estudio de tales 
saberes, es decir, que el género atraviesa todo el conocimiento científico y sus nociones anexas (Perona, 2000). Como dice Margot Pujal:

La perspectiva crítica feminista se propone examinar la forma en que esta ideología particular está presente en el discurso científico moderno. Partiendo de un análisis contextualizado de la forma en que operan las dicotomías jerárquicas modernas, estas pensadoras feministas ponen de manifiesto que las dicotomías, presentes en el discurso científico, en su retórica de la verdad se sirven de disimetrías tales como: público-privado, impersonal-personal, razón-emoción, abstracción-concreción, instrumental-afectivo y masculino-femenino, que identifica el primero de sus términos con a subjetividad construida como universal y marcada por el género masculino (...) (Pujal, 1994, p.135).

Ningún objeto es neutro, está teñido y atravesado por significados e implícitos, y la mirada con que se aborda, la epistemología y metodologías que la "desentrañan", es una mirada de género. Todo ello no es sino una prueba más de que el modelo de conocimiento de las sociedades occidentales es ideológico, y que procede y se contrasta fundamentalmente a partir de las experiencias masculinas.

Las implicaciones de esta posición son múltiples. La primera de ellas, propiamente epistemológica (considerando la estrecha relación existente entre ciencia, ontología y filosofía práctica) y ya mencionada como prioritaria, es precisamente la que atañe a la definición de las nociones de sujeto y objeto. En efecto, permite desenmascarar sus definiciones tradicionales al desvelar la relación incontestable que existe entre los aspectos lógicos y metodológicos con que las epistemologías abordan el conocimiento, y los aspectos sociológicos y psicosociales que definen tanto al sujeto y al objeto como a la propia institución en que se ubican. El sujeto de conocimiento es una subjetividad que, lejos de ser abstracta, está claramente situada. Tal como sostiene Evelyn Fax Keller (1985), la presunta neutralidad y objetividad de la ciencia, en sus aspectos psicológico y cognitivo, es una construcción masculina. Un sujeto de conocimiento es un sujeto con una preconcepción del mundo, no un individuo abstracto, ahistórico e incorpóreo. Por tanto, la subjetividad está situada y se encuentra tanto en el sujeto como en el objeto, así como en la relación que se establece entre ellas.
Otra de sus implicaciones tiene que ver con el método. Tal y como consideran sus teóricas, el método empleado por la física no puede ser el modelo a seguir por cualquier método de conocimiento científico que no sería sino un método atípico, una excepción (Harding, 1986, 1993). Dicho método no tiene en cuenta los elementos y determinaciones sociales que afectan al sujeto y al objeto de conocimiento, y tampoco considera o cuestiona las conductas intencionales basadas en prejuicios de producción utilizados de forma consciente en base a una finalidad y objetivo definidos.

Además de estas consideraciones, una parte de la perspectiva epistemológica feminista critica toda teoría que se pretenda universal. Para ello, se basa en la subjetividad y la concepción fragmentada de las subjetividades (Haraway, 1991), lo que en el ámbito de la epistemología significa tener en cuenta las particularidades de los sujetos de conocimiento y del propio objeto del mismo. Así pues, utilizar las producciones y formulaciones de la epistemología feminista implica considerar que cualquier teoría de la ciencia no puede establecer de manera estándar la comprensión de su objeto de estudio sin reflexionar acerca de quién es el sujeto de conocimiento, qué posición ocupa, cómo está influyendo el género en los métodos utilizados y, una cuestión central, qué podemos entender por ciencia.

La riqueza de la epistemología feminista radica en su claro posicionamiento de crítica social. Los principios orientadores de las teorías y prácticas feministas se han materializado en duras críticas hacia los procesos sociales, políticos, históricos de desigualdad y dominación. El concepto de transformación de las relaciones sociales sigue teniendo su vigencia desde las primeras formulaciones y sigue siendo el motor de orientación de todos sus desarrollos teórico-conceptuales. Pero el pensamiento feminista no ha conseguido únicamente cambios en los planos vistos hasta el momento. Para una agenda post-construccionista otras aportaciones son también extraordinariamente importantes. En particular, me referiré a continuación a la performatividad.

\section{Performatividad}

Como sabemos, una de las críticas mas crudas al construccionismo ha consistido en atribuirle un cierto idealismo linguístico. No hay problema 
en reconocer que al enfatizar la importancia del lenguaje y la naturaleza discursiva de las prácticas sociales, el socio-construccionismo ha contribuido a desencializar, denaturalizar y des-psicologizar al individuo y a los procesos psico-sociales. Pero seguramente eso también le ha llevado a desatender lo que podría ser llamado "prácticas no lingüísticas", No es el caso de todo el construccionismo, pues como vimos anteriormente, una lectura foucaultiana del discurso y la práctica discursiva no anula ni desprecia la materialidad, sino que más bien la recoloca en otro lugar del escenario. No obstante, siempre se puede decir que quizás se ha ignorado en demasía el efecto de objetos y materialidades que generan sus efectos utilizando medios no estrictamente lingüísticos.

La emergencia del llamado "pensamiento queer" o "teoría queer" (Fernández, 2000; Llamas, 1998; Mérida Jiménez, 2002; Preciado, 2002) y específicamente el enfoque de la performatividad de Judith Butler, ayuda a subsanar este problema y a abrir un campo nuevo de interés, cual es la subjetivación y las prácticas de subjetivación y a ofrecer nuevos elementos en una agenda política radical.

Confieso, aunque a algunas personas le pueda parece exagerado, que nunca desde Foucault recibí una bofetada tan grande con la lectura de un texto, como cuando leí la obra de Judith Butler.

Judith Butler ha perfilado la noción de performatividad. Máxima representante de la "teoría queer", su planteamiento viene a revolucionar las nociones de identidad, subjetividad y prácticas de subjetivación en su análisis-propuesta en torno a la producción preformativa de la identidad sexual. Se trata de una posición antiesencialista que niega tanto el carácter natural de la identidad como su carácter fijo y estable. La identidad es una construcción social, efectivamente, pero una construcción que debe entender se como un proceso abierto a constantes transformaciones y redefiniciones.

Para Judith Butler $(1990,1993)$ la identidad no es algo expresivo, algo en lo que el género responda a una esencia íntima que se exprese en la forma de rol característico, es decir, alguna cosa donde el sexo sea el núcleo natural que se atualice en las prácticas de género. Esa concepción sería sólo una matriz específica de inteligibilidad de corte heterosexual, un marco normativo dentro del cual se producen las identidades sexuales. Para
Butler, por el contrario, el género no es una expresión de una esencia natural, el sexo, sino mas bien un efecto de la división social entre los géneros (Córdoba, 2002; Gil, 2002). Pero, además, hace una propuesta mucho más radical: propone un giro en la relación entre sexualidad y género, puesto que la versión convencional implica una naturalización de las identidades de género a través de su anclaje en el sexo que no es sino el efecto de un dispositivo político de reproducción de la heterosexualidad. El sexo como lo natural y el género su expresión socio-cultural no son sino efectos de la sexualidad como régimen normativo:

Si el género es algo construido, no lo es necesariamente por un "yo" o un "nosotros" que existan antes que la construcción, en ningún sentido espacial o temporal del término "antes". En realidad, no está muy claro que pueda haber un "y" o un "nosotros" que no haya sido sometido, que no esté sujeto al género, si por "generización" se entiende, entre otras cosas, las relaciones diferenciadoras mediante las cuales los sujetos hablantes cobran vida. Sujeto al género, pero subjetivado por el género, el "yo" no está ni antes ni después del proceso de esa generización, sino que sólo emerge dentro (y como la matriz de) las relaciones de género mismas. (...) Afirmar que el sujeto es producido dentro de una matriz - y como una matriz generizada de relaciones no significa suprimir al sujeto, sino sólo interesarse por las condiciones de su formación y su operación. La "actividad" de esta generización no puede ser, estrictamente hablando, un acto o una expresión humanos, una apropiación voluntaria y, cuertamente no se trata de adoptar una máscara; es la matriz la que hace posible toda disposición previa, su condición cultural capacitadora. En este sentido, la matriz de relaciones de género es anterior a la aparición de "lo humano" (Butler, 1993, p.25).

Así pues, en este sentido la identidad sexual no es la expresión o manifestación externa de un núcleo natural o esencial sino por el contrario que la idea misma de ese núcleo es un efecto de una identidad que no es otra cosa que su propia manifestación. El género es una puesta en escena detrás de la cual no hay un núcleo que le dé consistencia. El sujeto es constituido en este proceso, no es anterior a él.

Uno se convierte en lo que es en la medida en que reconoce en ese ser 10 que ya-desde siempre ha sido, pero eso no es posible sin un acto previa de interpelación/socialización. Para Butler el sexo es un efecto del 
proceso de naturalización de la estructura social del género y la matriz heterosexual. El sujeto es llamado a identificarse con una determinada identidad sexual y de género sobre la base de una ilusión de que esa identidad responde a una interioridad que siempre estuvo allí incluso antes del acto de interpelación. Este es el centro de la concepción performativa del género. No hay una esencia detrás de las performances o actuaciones del género del que estas sean expresiones o externalizaciones. Al contrario, son las propias actuaciones (performances) en su repetición compulsiva las que producen el efecto-ilusión de una esencia natural:

no hay una identidad de género detrás de las expresiones de género; esa identidad se constituye performativamente por las mismas expresiones que, según se dice, son resultado de ésta (Butler, 1990, p.58).

Este concepto de performatividad tiene su anclaje en la idea del acto de habla performativo (o realizativo), aquél que, según John Austin (1962) el decir algo equivale a hacer algo. Austin (1962) los distingue de los actos de habla constatativos, en los que simplemente el enunciado hace referencia a un hecho externo por la vía de la descripción y por lo tanto pueden ser juzgados en términos de verdaderos o falsos en función de que se ajusten en tanto que enunciados descriptivos a los hechos a los que se refieren. El acto performativo al contrario habrá de ser considerado en términos de su eficacia, de su éxito o fracaso y de los efectos que produzca. La interpelación del acto performativo no se dirige, como pretende, a un sujeto que ya existe antes de este acto, sino que, en sentido estricto, lo produce.

La voluntad política, emnacipadora de Butler le lleva a cambiar la pretensión de Austin de desarrollar un análisis de esos actos y de las condiciones que los posibilitan y que determinan su eficacia por considerar las condiciones que posibilitan el fracaso del performativo, y por lo tanto el fracaso de la interpelación del género. Incluso, más allá de las condiciones de posibilidad/imposibilidad del éxito del performativo, Butler se interesa en discernir qué procesos y qué actos de hecho ponen a la luz estas condiciones y efectúan una subversión de su sentido. El análisis de la performance "drag" es el ejemplo prototípico que Butler utiliza pues pone de manifiesto el alcance y el poder de subversión contra el éxito de la subjetivización heterosexual. En este sentido, sin negar la carga de autoridad que se transmite en la enunciación performativa, lo que Butler explora es la posibilidad de fracaso, la posibilidad de re-apropiarse de la fuerza performativa, de la autoridad que transmite y por tanto la subversión de sus efectos, es decir, la posibilidad de resistencia.

Para mi argumento, el planteamiento de Judith Butler viene a ofrecer una alternativa tanto a la noción de construcción social como a los límites de la discursividad. En efecto, siguiendo a Butler, la cuestión no es si todo es una construcción social o si todo se construye discursivamente, porque cuando se plantean las cosas así, se está negando la fuerza constitutiva de la performance. Lo que Butler está proponiendo es una noción de construcción que implica una especie de "vuelta" a la materia. Pero una materia que no es sitio o superficie como ella misma dice, sino materia como "proceso de materialización que se estabiliza a través del tiempo para producir el efecto frontera, de permanencia y de superficie que llamamos materia" (Butler, 1993, p.28). Paralelamente, la construcción no es vista como un acto único o como un proceso de tipo causal iniciado por un sujeto del cual se deriven efectos. Mas bien, la construcción "no sólo se realiza en el tiempo, sino que es en sí mismo un proceso temporal que opera a través de la reiteración de normas" (Butler, 1993, p.29).

Sobre la cuestión de la discursividad, la posición de Butler es aún, si cabe, más radical. La apelación anti-construccionista de que siempre hay "algo" externo al discurso, distinto y anterior a él, es respondida por Butler de forma contundente. Referirse a algo extradiscursivo implica que se ha de delimitar previamente cuál es ese ámbito de lo extradiscursivo, y caso de poder delimitarse, entonces, y paradójicamente, será lo discursivo lo que estará delimitado por el discurso mismo del que pretendía liberarse.

Así pues, la performatividad no es sólo una acción lingüística, un acto de habla intencional del sujeto, sino una forma de poder. En efecto,

para poder materializar una serie de efectos, el discurso debe entenderse como un conjunto de cadenas complejas y convergentes cuyos 'efectos' son vectores de poder. En este sentido, lo que se constituye en el discurso no es algo fijo, determinado por el discurso, sino que llega a ser la condición y la oportunidad de una acción adicional. Esto no equivale a decir que puede darse cualquier acción sobre la base de un efecto discursivo. Por el contrario, ciertas cadenas reiterativas de producción discursiva apenas son legibles 
como reiteraciones, pues los efectos que han materializado son tales que sin ellos no es posible seguir ninguna orientación en el discurso. El poder que tiene un discurso para materializar sus efectos es pues consonante con el poder que tiene para circunscribir la esfera de inteligibilidad. Es por ello que interpretar la 'performatividad' como una decisión voluntaria y arbitraria implica pasar por alto que la historicidad del discurso y, en particular, la historicidad de las normas (las 'cadenas' de iteración invocadas y disimuladas en la enunciación imperativa) constituyen el poder que tiene el discurso de hacer realidad lo que nombra (Butler 1993, pp.267-268).

\section{Psicología social crítica: hacia la acción social}

En los apartados anteriores hemos descrito algunos elementos característicos del construccionismo social, algunos de los problemas que se le plantean, así como el esbozo de nuevas tendencias y orientaciones que se han ido gestando en los últimos años, a veces en paralelo y otras al lado del construccionismo. Todo ello permite, creo, rediseñar la caja de herramientas para una "refundación" de una perspectiva crítica. En este sentido, pretende ser una contribución más a una perspectiva que ha sido etiquetada unas veces como "Psicología Social Crítica" (Hepburn, 2002; Ibáñez e Iñiguez, 1997), otras, "Nueva Psicología Social” (Ibáñez, 1989), "Corriente Alternativa" (Ibáñez, 1990), o "Psicología Social como Crítica" (Domenech e Ibáñez, 1998).

Estas denominaciones diferentes no borran, sin embargo, una sintonía de base que es común, unas características que siempre están en su interior, una perspectiva similar, una mirada propia e identificable, una comprometida práctica de problematización. Algunas de estas características han sido resumidas por Tomás Ibáñez:

A un nivel muy general, esta psicología social "diferente" asume un "giro construccionista" (en a esfera ontológica), un "giro interpertativo/lingüístico" (en el nivel de la metodología) y un "giro "no-fundamentalista" (en el plano epistemológico, incluso aunque la más radical de las críticas cuestione el propio concepto de epistemología) (Ibáñez, 1997, p.29).
Una "Psicología Social Crítica" es entonces la consecuencia de un continuo cuestionamiento y problematización de las prácticas de producción de conocimiento y por tanto tiende a recoger la mayor parte de las características que he enunciado, es decir, la historicidad del conocimiento, el carácter interpretativo del ser humano, lo que hemos llamado el talante construccionista, la reflexividad del conocimiento, las aportaciones de la epistemología feminista y del conocimiento situado, la eclosión de los estudios sociales de la ciencia y la tecnología, la performatividad, etc. Sin embargo, si hasta hace poco decíamos (Garay, Iñiguez, Martínez, 2001) que, tanto en lo que se refiere a las asunciones ontológicas, como epistemológicas, metodológicas, políticas, etc. Esta perspectiva se integraba en ese movimiento de tipo general que podemos denominar "construccionista", hoy diré que se expande en la eclosión de perspectivas del nuevo paisaje post-construccionista y que se enrola en el proyecto/intento de permeabilización de las disciplinas científico-sociales, convirtiéndose en un magma informe que impregna lugares y recovecos en el ámbito genérico de las humanidades y las ciencias sociales.

Si hace poco dije en otro lugar que

en los últimos anos, las concepciones epistemológicas, teóricas y metodológicas subyacentes en las prácticas de la psicología social estándar han cambiado profundamente, se han dejado penetrar ideas y planteamientos de otras disciplinas distintas de la psicología social y de la psicología, de la epistemología feminista y de los estudios gay y lésbicos, ha habido un giro lingüístico y discursivo notorio, una oposición radical al positivismo, una severa crítica al individualismo, un compromiso con los procesos de cambio políticos y sociales, una difuminación de las fronteras de lo teórico y

${ }^{1}$ He distinguido en otro lugar (Iñiguez, 2003) entre "Psicología Social Crítica" y "Psicología Social Radical". Ambas estarían implicadas en un tipo de mirada crítica y problematizadora, aunque la "Psicología Social Radical" estaría poniendo mayor énfasis en los aspectos políticos que en los epistemológicos o metodológicos: "La Psicología social radical enfatiza la transformación del orden social, es una psicología implicada en las procesos de emancipación y de cambio social. La Psicología social radical puede ser, por tanto, crítica o no. La Psicología social radical tiene que ver con el cambio social, pero no únicamente en el sentido de la introducción de cambios, sino como sostiene Tajfel, también en el sentido de la propia transformación como práctica social. (...) El mejor ejemplo de esta clase de psicología social es probablemente el libro de Wexler (1977)" (Iñiguez, 2003). 
lo metodológico, etc. En definitiva, hay una "nueva psicología social". (...) Sus ejes, dicho en breve, se estructuran en torno a la intersubjetividad y el imaginario social, a las perspectivas postestructuralistas y construccionistas, a los planteamiento postmodernos, al abandono de las grandes narrativas, al análisis del discurso, el análisis conversacional y la psicología discursiva como alternativa seria al cognitivismo dominante y, cómo no, al relativismo (Iñiguez, 2000, p.155)

Hoy diría, además de todo eso, que los ejes ya no son tales, sino una malla donde los nudos son acontecimientos y posicionamientos inestables y sus hilos, conceptos híbridos de difícil si no imposible etiquetación. En consecuencia, la acción de producir conocimiento, ya se enmarque en el espacio de las ciencias sociales en general o bajo el título específico de psicología social crítica, no podrá ignorar las nuevas condiciones que la posibilitan así como las consecuencias que desencadenan.

La agenda entonces es más política que científica, cualquier cosa que quiera significar científica en este contexto. Debo decir entonces que convengo con Alejandro Moreno (1993) en que lanzarse a investigar hoy después del cuestionamiento crítico de todas las bases epistemológicas de los métodos y de la ciencia misma, hace ineludible una reflexión en torno a las bases que fundamentan todo el trabajo de investigación que nos propongamos efectuar. En sus palabras: "en la actualidad, seguramente, ya no es el problema de la verdad el que se plantea (...), sino el de la responsabilidad" (Moreno, 1993, p.21). Y también convengo con Judith Butler (2001) en la idea de que

la teoría es en sí misma transformadora (...), no pienso que la teoría sea suficiente para la transformación social y política. Además de la teoría debe haber algo más, intervenciones a nivel social y político que implican acciones, trabajo sostenido, práctica institucionalizada que no son exactamente lo mismo que el ejercicio de la teoría, aunque yo también añadiría que en todas estas prácticas se presupone la teoría. En el mismo acto de transformación social todas las personas somos filósofas no expertas, presuponiendo una visión del mundo, de lo que está bien, de lo que es justo, de lo que es detestable, de lo que la acción humana es o puede ser, de lo que constituyen las condiciones de vida necesarias y suficientes (Butler. 2001, p.7).
Vivimos en un mundo globalizado y complejo, por utilizar las expresiones al uso. Pero, ¿vivimos? Mejor aún, ¿vivimos todos? Creo que la respuesta es no, y algo habrá que hacer. Se criticó al construccion1smo su escaso interés por las cuestiones "reales", lo que verdaderamente importa. No creo que fuera una crítica justa para el construccionismo ni creo que sea invitable para el nuevo escenario post-construccionista.

Global, complejidad, liquidez, flujo o red son conceptos que recurrentemente se utilizan para describir metafóricamente las sociedades contemporáneas, a las que acompañan, y que con frecuencia empiezan a sustituir progresivamente, a las expresiones más comunes de sociedad postindustrial, sociedad de la información, sociedad del conocimiento y otras similares (Bauman, 2000; Urry, 2000).

¿Podrían esta caja de herramientas que se va elaborando en la era post-construccionista, y que yo he tratado de reflejar en esta conferencia, ser un nuevo arsenal conceptual ser útil para replantear una acción social comprometida políticamente? ¿Ofrecería, nuevas perspectivas para la acción? En rigor, no hay una respuesta a estas preguntas, pero sí que existe un campo de nuevas posibilidades para explorar. Permítanme entonces acabar apropiándome de las palabras de una de mis heroínas, Judith Butler:

Lo que me mueve políticamente es el momento en que un Sujeto una persona, un colectivo - afirma su derecho o autoridad para una "vida vivible" cuando no existe una autorización previa, cuando no hay una convención clara que le capacite. (...) Vivir es vivir una vida políticamente, con relación al poder, con relación a las otras personas, en el acto de asumir responsabilidad para un futuro colectivo. Sin embargo, asumir responsabilidad para un futuro no es saber su dirección exacta de antemano, ya que el futuro, especialmente el futuro con y por las otras personas, requiere cierta apertura y desconocimiento y eso también implica que cierto antagonismo y enfrentamiento entrará en juego. (...) No es un proceso predecible, debe ser experimentado, igual que debe serlo una pasión. También puede ser que la vida misma se cierre de antemano cuando el camino correcto sea decidido de antemano, cuando impongamos lo que está bien para todo el mundo sin encontrar un modo de entrar en la comunidad y descubrir en ella "lo correcto" en el núcleo de una traducción cultural. Puede ser que lo que está "bien" y es "bueno" consista en estar abiertas a las tensiones que acosan a las categorías básicas que requerimos, en 
saber nuestro esencial desconocimiento de lo que conocemos y necesitamos, y en reconocer la señal de la vida - y sus perspectivas - en nuestras respuestas para convivir unas personas con otras (Butler, 2001, pp.29-30).

\section{Referências}

Armistead, N. (Ed.). (1974). La reconstrucción de la Psicología Social. Barcelona: Hora, 1983.

Ashmore, M. (1989). The reflexive thesis: wrighting sociology of scientific knowledge. Chicago: Chicago University Press.

Austin, J. (1962). Cómo hacer cosas con palabras. Barcelona: Paidós, 1982.

Bauman, Z. (2000). Liquid modernity. Cambridge: Polity Press.

Berger, P. \& Luckmann, T. (1967). La construcción social de la realidad. Madrid: Amorrortu-Murguía, 1986.

Billig, M. (1987). Arguing and thinking. Cambridge: Cambridge University Press.

Brown, S. (2002). Psychology without foundations. History and Philosophy of Psychology, 4, 1, 69-83

Bruner, J. (1990). Actos de significado. Más allá de la revolución cognitiva. Madrid: Alianza Editorial, 1991.

Burr, V. (1997). Una introducción al construccionisme social. Barcelona: EDIUOC.

Butler, J. (1990). El género en disputa. El feminismo y la subversión de la identidad. México: Paidós. 1999.

Butler, J. (1993). Cuerpos que importan. Sobre los límites materiales y discursivos del "sexo". Buenos Aires: Paidós, 2002.

Butler, J. (2001). La cuestión de la transformación social. In E. BeckGernsheim, J. Butler \& L. Puigvert. Mujeres y transformaciones sociales (pp.7-30). Barcelona: El Roure.
Callon, M. (1992). El proceso de construcción de la sociedad. El estudio de la tecnología como herramienta de análisis sociológico. In $\mathrm{M}$. Doménech \& F. J. Tirado (Eds.). (1998). Sociología simétrica. Ensayos sobre ciencia, tecnología y sociedad (pp.143-170). Barcelona: Gedisa.

Callon, M. \& Law, J. (1982). De los intereses y su transformación. Enrolamiento y contraenrolamiento. In M. Doménech \& F. J. Tirado (Eds.). (1998). Sociología simétrica. Ensayos sobre ciencia, tecnología y sociedad (pp.51-61). Barcelona: Gedisa.

Córdoba, D. (2002). Teoría Queer. Reflexiones sobre sexo, sexualidad e identidad. Trabajo de investigación. Programa de Doctorat en Sociología. Departament de Sociología. Universitat Autónoma de Barcelona.

Doménech, M. (1998). El problema de "lo social” en la Psicología Social. Anthropos, 177,34-39.

Doménech, M. \& Ibáñez, T. (1998). La Psicología Social como crítica. Anthropos, 177, 12-21.

Doménech, M. \& Tirado, F. J. (Eds.). (1998). Sociología simétrica. Ensayos sobre ciencia, tecnología y sociedad. Barcelona: Gedisa.

Doménech, M., Iñiguez, L. \& Tirado, F. J. (2003). George Herbert Mead y la Psicología Social de los objetos. Revista Psicología \& Sociedade, 15,1 .

Edwards, D. (1997). Discourse and cognition. London: Sage.

Edwards, D. \& Potter, J. (1992). Discoursive psychology. London: Sage.

Fernández, J-A. (Ed.). (2000). El gai saber. Introducción als estudis gais $i$ lèsbics. Barcelona: Llibres de l'Index.

Gadamer. H. G. (1960/1991). Verdad y método. Salamanca: Sígueme.

Garay. A. Iñiguez. L. \& Martínez. L. M. (2001. Sept.). Perspectivas críticas en Psicología Social. Herramientas para la construcción de nuevas psicologías sociales. Boletín de Psicología. 72.57-78.

Garfinkel. H. (1967). Studies in Etnomethodology. Englewood Cliffs. NJ: Prentice Hall. 
Gergen. K. (1998). La Psicología Social como historia. Anthropos. 177. 3948.

Gergen. K. (1982). Toward transformation in social knowledge. London: Sage. 1994.

Gergen. K. (1991). El yo saturado. Dilemas de identidad en el mundo contemporáneo. Barcelona: Paidós. 1992.

Gergen. K. (199411995). Realidades y relaciones. Aproximaciones a la construcción social. Barcelona: Paidós.

Gergen. K. (1999). An invitation to social construction. London: Sage.

Giddens. A. (1982). Profiles and critiques in social theory. London: MacMillan.

Giddens. A. (1984). The construction of society. Outline of a theory of structuration. Cambridge: Cambridge University Press.

Gil. E. P. (2002) — ¿Por qué le llaman género cuando quieren decir sexo? Una aproximación a la teoría de la performatividad de Judith Butler. Atenea Digital, n. 2. Retirado em 30 ago. 2003. <http:// antalya. uab.es/athenea/num2/gil.pdf>.

Greenwood. J. D. (1994). Realism, identity and emotion. Reclaiming social psychology. London: Sage.

Hacking. L. (1998) ¿La construcción social de qué? Barcelona: Paidós. 2001.

Haraway. D. J. (1991). Ciencia, cyborgs y mujeres. La reinvención de la naturaleza. Madrid: Cátedra. 1995.

Harding. S. (1986). The science question in feminism. Ithaca: Cornell University Press.

Harding. S. (1993). Ciencia y feminismo. Madrid: Morata. 1996.

Harré. R. (Ed.). (1986). The social constructions of emotion. Oxford: Basil Blackwell.

Henriques. J. et al. (1984). Changing the subject. Psycholohy, social regulation and subjectivity. London: Methuen Reisued 1998. London: Routledgel.
Heritage. J. (1984). Garfinkel and ethnomethodology. Cambridge: Cambridge University Press.

Hepburn. A. (2002). Critical Social Psychology. London: Sage.

Hibberd, F. J. (2001a). Gergen's social constructionism, logical positivism and the continuity of error. Part 1: Conventionalism. Theory and Psychology, II , 3, 297-321.

Hibberd, F. J. (2001 b). Gergen's social constructionism, logical positivism and the continuity of error. Part 2: Meaning-as-use. Theory and Psychology, II, 3, 323-346.

Ibáñez, T. (Comp.) (1989). El conocimiento de la realidad social. Barcelona: Sendai.

Ibáñez, T. (1990). Aproximaciones a la psicología social. Barcelona: Sendai.

Ibáñez, T. (1994). Psicología social construccionista. Guadalajara (México): Universidad de Guadalajara.

Ibáñez, T. (1996). Fluctuaciones conceptuales en torno a la postmodernidad y la psicología. Caracas: Universidad Central de Venezuela.

Ibáñez, T. (1997). Why a Critical Social Psychology? In T. Ibáñez \& L. Iñiguez (Eds.). Critical Social Psychology (pp.27-41). London: Sage.

Ibáñez, T. (2001). Municiones para disidentes. Realidad-Verdad-Política. Barcelona: Gedisa.

Ibáñez, T. (en prensa). La construcción social del socio-construccionismo: retrospectiva y perspectivas. Política y Sociedad.

Ibáñez, T. \& Iñiguez, L. (Eds.) (1997). Critical Social Psychology. London: Sage.

Ibáñez, T. \& Iñiguez, L. (2000). Psicología social como crítica Emergencias de y confrontaciones con la Psicología Social, académicamente definida en 2000. In A. Ovejero (Ed.). La psicología social en España al filo del ano 2000: balance $y$ perspectivas (pp.139-157). Madrid: Biblioteca Nueva. 
Ibáñez, T. \& Iñiguez, L. (en prensa). La Psicología social como crítica: continuismo, estabilidad y efervescencias tres décadas después de "la crisis". Revista Interamericana de Psicología, 37, 2.

Jenkins, A. H. (2001). Individuality in cultural context. The case for psychological agency. Theory and Psychology, 11, 3, 347-362

Keller, E. F. (1985). Reflexiones sobre género y ciencia. Valencia: Alfons el Magnànim. 1989.

Kitzinger, C. (1987). The social construction of lesbianism. London: Sage Publications.

Knorr-Cetina, K. (1996). Epistemic cultures: how scientists make sense. Cambridge, Mass: Harvard University Press.

Latour, B. (1991a). Nous n'avons Jamais été modernes. Essai d'anthropologie symétrique. Paris: La Découverte.

Latour, B. (1991b). La tecnología es la sociedad hecha para que dure. In M. Doménech \& F. J. Tirado (Eds.). (1998). Sociología simétrica. Ensayos sobre ciencia, tecnología y sociedad (pp. 109-142). Barcelona: Gedisa.

Latour, B. (1991c). One more turn after the social turn. Easing science studies into the non-modern world. In E. McMullin (Ed.). The social dimensions of science. Notre Dame: Notre Dame University Press.

Latour, B. \& Woolgar, S. (1986/1995). La vida en el laboratorio. La construcción de los hechos científicos. Madrid: Alizanza. [1a ed. 1979].

Law, J. (1987). Technology and heterogeneous engineering: the case of portuguese expansion. In W. E. Bijker, T. H. Hughes \& T. J. Pinch (Eds.). The social construction of technological systems. New directions in the sociology and history of technology (pp.111-134). Cambridge: The MIT Press.

Law, J. \& Hassard, J. (Eds.). (1999). Actor network theory and after. Oxford: Blackwell.

Liebrucks, A. (2001). The concept of social construction. Theory and Psychology, 11, 3, 363-391.
Llamas, R. (1998). Teoría torcida. Prejuicios y discursos en torno a 'la homosexualidad'. Madrid: Siglo XXI.

Maze, J. R. (2001). Social constructionism, deconstruction and some requirements of discourse, Theory and Psychology, 11, 3, 393-417.

Mead, G. H. (1934). Espíritu, persona y sociedad. México: Paidós. 1993.

Mérida Jiménez, R. M. (Ed.). (2002). Sexualidades transgresoras. Una antología de estudios queer. Barcelona: Icaria.

Moreno, A. (1993). El aro y la trama. Episteme, modernidad y pueblo. Caracas: Centro de Investigaciones Populares.

Nightingale, D. J. \& Cromby, J. (Eds.). (1999). Social constructionist psychology: a critical analysis of theory and practice. Buckingham: Open University Press.

Parker, I. (Ed.). (1998). Social constructionism, discourse and realism London Sage.

Parker, I. \& Shotter, J. (1990). Deconstructing social psychology. London: Routledge.

Perona, A. (2000). Epistemología feminista. In J. Munoz \& J. Velarde (Eds.). Compendio de epistemología. Madrid: Trotta.

Potter, J. \& Wetherell, M. (1987). Discourse and Social Psychology. Beyond Attitudes and Behaviour. Londres: Sage.

Potter, J. (1996/1998). La representación de la realidad. Discurso, retórica y construcción social. Barcelona: Paidós.

Preciado, B. (2002). Manifiesto contra-sexual. Madrid: Opera Prima.

Pujal. M. (1994). La marca del género en la encrucijada entre subjetividad e intersubjetividad. Iztapalapa. Revista de Ciencias Sociales y Humanidades, ano XIV, 35, 131-142.

Ricoeur, P. (1981). Hermeneutics and the human science. Cambridge: Cambridge University Press.

Rorty, R. (1979). La filosofía y el espejo de la naturaleza. Madrid: Cátedra, 1983. 
Rose, N. (1989). Gouverning the Soul. The Shaping of the Private Self. London: Routlege.

Rose, N. (1996). Inventing our selves. Cambridge: Cambridge University Press.

Sampson, E.E. (1986). What has been inadvertenly rediscovered? A comentary. Journal for the Theory of Social Behaviour, 16, 33-39.

Serres, M. (1990). El contrato natural. Valencia: Pre-textos. 1991.

Serres, M. (1980). Le Parasite. Paris: Gasset.

Shotter, J. (1987). The rhetoric of theory in psychology. In Current issues in theoretical psychology (pp.283-296).

Shotter, J. (1993a). Cultural politics of everyday life. Buckingham: Open University Press.

Shotter, J. (1993b). Conversational realities. Londres: Sage.

TayIor, C. (1985). Human agency and language. Philosophical papers (v. 1). Cambridge: Cambridge University Press.

Urry, J. (2000). Sociology beyond societies. Mobilities for the twenty-first century. London: Routledge.

Varela, J. (1996). Introducción: psicología política y resistencia (PPR). In A. J. Gordo \& J. L. Linaza (Comps.). Psicologías, discursos y poder $(P D P)$ (pp.319-323). Madrid: Visor.

Velody, R. \& Williams, R. (Eds.). (1998). The politics of constructionism. London: Sage.

Vázquez, F. (1998). Vivir con el tiempo en suspenso: notas de trabajo sobre transiciones políticas, memorias e historia. Anthropos, 177, 67-72.

\section{SIMPÓSIO 1 - TECNOLOGIAS DA INFORMAÇÃO E DA COMUNICAÇÃO E MODOS DE SUBJETIVAÇÃOO}

\section{A comunicação como nova dimensão da produção de subjetividade}

André Parente

"A memória é uma ilha de edição" (Wally Salomão)

Félix Guattari (1992) chamou a atenção para o fato de que o inconsciente, seja ele freudiano ou lacaniano, nada mais era do que um modo de produção de subjetividade entre outros. Longe de ser apenas algo como uma "faculdade da alma", ele é inseparável da produção de signos e das instituições. Para ele o inconsciente é um verdadeiro equipamento coletivo de subjetivação, uma nova maneira de fazer sentir e mesmo de produzir a histeria, a neurose e a psicose, comparável aos sentimentos do amor cortês do cavaleiro medieval, do sentimento de classe do bolchevique, do sentimento de guerra religiosa do fundamentalista.

A sociedade e a cultura produzem equipamentos ou máquinas de modelização da subjetividade: máquinas iniciáticas, sociais, retóricas, afetivas embutidas nas instituições (religiosas, militares, corporativas, financeiras), nas tecnologias (língua, escrita, livro, computador) e nos dispositivos (câmera escura, panóptico, televisão, realidade virtual).

Se Michel Foucault, Gilles Deleuze e Félix Guattari foram acusados de anti-humanismo é porque eles sustentavam que a subjetividade dependia cada vez mais de uma infinidade de sistemas maquínicos, entre eles as tecnologias de informação e comunicação. Podemos dizer que as diversas tecnologias info-comunicacionais formam uma espécie de inconsciente maquínico que rivaliza, hoje, com o inconsciente econômico e psicológico. Lembremos que na passagem do século XIX ao século XX várias formas de inconscientes surgiram como tanto vetores de produção de subjetividade: inconsciente econômico com Marx, inconsciente psicológico com Freud, inconsciente corporal com Nietzsche, inconsciente linguístico com Saussure, inconsciente imagético com Bergson. 
Para todos estes pensadores, o inconsciente condiciona nossos pensamentos, discursos, desejos, sentimentos, comportamentos, etc. Por exemplo. para a linguística de origem saussuriana, não podemos sequer pensar uma realidade exterior que não seja, desde sempre, prélinguisticamente formada. Isto equivale a dizer que quando pensamos, é a língua que pensa; quando falamos, é a língua que fala, etc. Língua e realidade se confundem: o referente exterior sendo pura miragem. Aliás foi exatamente esta ideia que, mais tarde levou Jean Baudrillard (1991) a formular sua estética da desaparição, em que o real é uma miragem criada pela imagem-simulacro.

O campo conceitual de subjetivação surge nos trabalhos de Foucault. Deleuze e Guattari (1995) associado a dois movimentos. Por um lado, o sujeito é processual e não uma essência ou uma natureza: não há sujeito, mas processo de subjetivação. Por outro lado, a subjetivação é o processo por meio do qual os indivíduos e coletividades se constituem como sujeitos, ou seja, só valem na medida em que resistem e escapam tanto aos poderes e saberes constituídos. Os poderes e saberes suscitam resistências. O que resiste é uma força que ao invés de afetar e ser afetada por outras forças vai se autoafetar. Esta autoafecção é a dobra, a autopoiesis (Varela e Maturana).

Por um lado, portanto, há a ideia da produção de sujeito, por outro a ideia de que a produção de subjetividade é, desde sempre a da questão da produção do novo, ou melhor, daquilo que escapa aos poderes e aos saberes. Como extrair dos esquemas sensórios-motores que a sociedade produz como condicionamentos, uma força que nos faça acreditar no mundo em que vivemos. Acreditar no mundo significa suscitar acontecimentos.

\section{Em Da produção de subjetividade, Guattari põe a questão':}

Como falar da subjetividade hoje? Uma primeira constatação nos leva a reconhecer que os conteúdos da subjetividade dependem, cada vez mais, de uma infinidade de sistemas maquínicos. Nenhum campo de opinião, de pensamento, de imagem, de afeto, de

${ }^{1}$ Texto publicado no livro: Parente. André (Org.). (1993). A imagem-máquina. Rio de Janeiro: Ed. 34. narratividade pode, daqui para a frente, escapar à influência invasiva da assistência por computador, dos bancos de dados, da telemática.

$\mathrm{Na}$ verdade, muitos dos grandes filósofos franceses contemporâneos estão de acordo que uma infraestrutura info-comunicacional estaria engendrando profundas transformações no sistema capitalista. Uma série de autores pensa a subjetividade em suas múltiplas relações com a história do pensamento (Michel Foucault, Michel De Certeau, Gilles Deleuze, Félix Guattari), a história do homem e das tecnologias cognitivas (Gilbert Simondon, André Lehoi-Gourhan, Pierre Lévy) a história da ciência e das tecnologias de comunicação (Jean-François Lyotard, Michel Serres, Bruno Latour, Paul Virilio, Jean Baudrillard, Régis Debray).

Muito já se discutiu sobre os impactos e efeitos das tecnologias de informação e comunicação. Há toda uma gradação de posições entre uma rejeição crispada de um Baudrillard até uma aceitação quase sem reservas de um Pierre Lévy. Todos concordam que vivemos em um tempo de mudanças. Os termos empregados para qualificar o nosso tempo - "era da informação", "era do simulacro", "era do virtual", "sociedade de controle" — já é uma admissão de que as mudanças são causadas em grande parte pelas novas tecnologias.

Concordamos inteiramente com a posição de Guattari (1992) sobre o fato de que, até agora, as novas tecnologias resultaram em um processo de estranha mistura de enriquecimento e empobrecimento, singularização e massificação, desterritorialização e reterritorialização, potencialização e despotencialização da subjetividade em sua dimensão autorreferencial (singularizante, processual, dissensual).

Ao invés de fazer como Baudrillard e Virilio cuja estética da desaparição nada mais é do que a atualização da metáfora da caverna em algo muito próximo da visão desiludida do filme Matrix, Guattari (1992) discute as condições de possibilidade do processo de subjetivação. Em primeiro lugar, ele afirma que a constituição maquínica da subjetividade deveria nos livrar dos temores de que uma pretensa essência humana da subjetividade estaria sendo ameaçada pelas máquinas. Em segundo lugar, ele nos aponta algumas condições para que as novas tecnologias desemboquem em uma era pós-mídia, na qual a massificação cederia lugar à singularização da inteligência e à valorização dos afetos. Entre as principais condições, citamos: a criação de territorialidades existenciais; a 
superação dos valores segregativos e disciplinares do capitalismo; a tomada de consciência de que a massificação leva ao enfraquecimento das vozes da autopoiesis.

Examinemos rapidamente as ideias de alguns autores para os quais as tecnologias avançadas estariam levando a um processo de regressão da subjetividade e das relações sociais.

É curioso que depois de ter se tornado o filósofo da velocidade, Virilio $(1993 ; 1994)$ condene o veículo do ciberespaço sob o pretexto de que ele levaria a uma anulação do espaço e a uma inércia polar. Se cada veículo produz uma nova relação com o espaço — o espaço que se estende diante de nós não é o mesmo se dispomos de um cavalo, um carro ou um avião - por que não aceitar as diferenças produzidas pelo novo veículo do ciberespaço? Além do mais, as redes, velhas ou novas, não se estendem apenas no espaço, o espaço são as redes.

Baudrillard (1991) teme que processo de virtualização leve a uma estética da desaparição do real, uma vez que na era do simulacro as imagens se tornam autorreferentes (sem referente social exterior) e o real se torna apenas uma miragem produzida pelo simulacro.

Lyotard (1990) teme que a informação, cujas mensagens devem ser todas codificadas em linguagem de máquina, transforme o saber em pura mercadoria para circular em suas redes de reprodução do capital. Lyotard problematiza ainda o destino da arte e do nosso corpo num mundo dominado pelo cálculo digital, que anulam o aqui e agora, suporte de todo sentimento estético.

Do ponto de vista conceitual, o que há de comum entre estes três pensamentos é que eles temem que a experiência do real através do virtual venha a ameaçar a experiência do possível. É preciso lembrar que ou o virtual é uma categoria estética que se apresenta como uma recriação do real recalcado ou é uma categoria tecnológica sem qualquer interesse.

O problema destas colocações é antes de tudo estratégico: Lyotard (1990), Virilio (1993; 1994) e Baudrillard (1991) não perceberam que as tecnologias de informação e comunicação constituem um novo espaço de lutas entre outros. Um espaço ainda mais importante porque se tornou uma nova dimensão do sistema produtivo e a este respeito não tem outro limite senão a finitude de nossos desejos.

Para outros autores, como veremos a seguir, as tecnologias não importam em si mesmo, mas em função dos agenciamentos coletivos que nelas se exprimem e produzem novas formas de subjetivação.

Em primeiro lugar, é preciso evocar Guattari, para quem a informática e a tecnociência não são nada mais do que formas hiperdesenvolvidas da própria subjetividade. Guattari (1992) observa que não são apenas as atuais máquinas informacionais e comunicativas que nos permite falar de uma produção maquínica da subjetividade, uma vez que as subjetividades pré-capitalistas e arcaicas eram engendradas por diversos equipamentos coletivos de modelização das formas de existência. Se a máquina resulta de um complexo processo de subjetivação e se a subjetividade é fruto de um agenciamento social múltiplo, não há porque separar a máquina e o homem sob a base da oposição natural/artificial, Todo corpo tem suas artificialidades, toda máquina tem suas virtualidades: são os agenciamentos sociais nos corpos e nas máquinas. Não há teoria da prótese que resista ao pensamento da hybris que desorganiciza o corpo ao colocá-lo em relação com o fora (corpo sem órgãos).

Devemos considerar também a tecnologia como fato cultural multitemporal, ou seja, acontecimentos singulares que remetem ao passado, ao presente ou ao futuro, formando um mapa dobrável e desdobrável como uma geometria variável. A cada dobra mudamos as conexões de seus componentes e extratos se refazem. O desenvolvimento da história da tecnologia se parece muito com as descrições das teorias do caos do tempo topológico: acontecimentos que parecem afastados estão muito próximos, ou o contrário. $\mathrm{Na}$ verdade, seria mais exato dizer que a multitemporalidade nos leva a uma outra concepção e imagem do tempo. $\mathrm{O}$ tempo multitemporal passa e não passa, ele escoa, mas não de modo uniforme e continuamente. Segundo Michel Serres (1998; 2000), ele funciona como um filtro, que ora faz passar e ora impede a passagem. É desta forma que as tecnologias remetem ao duplo movimento de aceleração e desaceleração, inovação e tradição. Se tomarmos um carro como exemplo, vemos que seus componentes remetem a épocas distintas: a roda remonta ao neolítico, a mecânica ao século XVIII, o motor e a termodinâmica ao século XIX e a eletrônica à contemporaneidade. Além 
disto, a forma como estes componentes se articulam no carro se modifica sem cessar. Diríamos mesmo que o que caracteriza o carro de hoje não é apenas o que nele é contemporâneo. É que a contemporaneidade se caracteriza cada vez mais pela edição ou a forma como as partes do sistema são montadas e articuladas. Se vivemos a época do homem dividido, do homem sem qualidades, ou sem essência, é porque operamos cada vez mais como um editor ou montador e nossa memória é cada vez mais como uma ilha de edição não-linear.

A ciência e a tecnologia são, para Bruno Latour, uma mega rede heterogênea que mobiliza homens e coisas e criam um campo de tensão e forças disparatadas. É impossível compreender a dinâmica da ciência, ou de qualquer outra rede, sem conhecermos as instituições — bibliotecas, museus, centros de informação, centros de pesquisa, centros de formação - os veículos materiais e os atores que intermediam a relação entre a periferia e centro das redes. O conjunto desta galáxia emaranhada, das redes e seus centros, funciona como um verdadeiro banco, dotando os capitalisadores de uma vantagem considerável, na medida em que eles estão ao mesmo tempo afastados dos lugares e interligados aos fenômenos por uma série reversível de transformações.

Se quisermos compreender como certas visões de mundo se impõem e se tornam dominantes, não podemos dispensar o processo de transformação do mundo em informação nas redes, sejam elas quais forem. A verdade sobre Deus, a verdade sobre a natureza e uma certa tendência na arte não existem fora das redes em que circulam, como se fossem fenômenos que falariam por si só.

A ciência não se aplica a partir das ideias de seus gênios. A ciência se replica, como o social, mas para que isto ocorra é preciso investimentos enormes. É verdade que as tecnologias apenas tornam mais visível a infraestrutura da rede da ciência.

Quando medimos as informações em bits e bauds, quando somos assinantes de um banco de dados, quando, para agir e pensar, nos conectamos a uma rede de comunicação, é mais difícil continuar vendo o pensamento científico como um espírito flutuando sobre as águas. Hoje a razão, que nada tem de natural, se assemelha muito mais a uma rede de comunicação, uma rede de telemática do que às ideias platônicas. ${ }^{2}$

Por fim, o trabalho de Latour nos leva a perceber que as tecnologias de informação e comunicação podem ser entendidas como tecnologias cognitivas menos por projetar ou exteriorizar a riqueza e complexidade dos processos cognitivos do pensamento do que por revelar o quanto sua complexidade deriva não apenas das capacidades naturais do homem, sejam elas biológicas ou psicológicas, mas também dos objetos, suportes e dispositivos técnicos que nos circundam e compõem as redes de informação. O que está em jogo é menos uma extensão de habilidades cognitivas dadas, uma prótese que prolonga e potencializa nosso pensamento e seus processos de produção, tratamento e transmissão de informações, que um processo contínuo de delegação, partilha e distribuição das atividades cognitivas que formam uma rede com os diversos dispositivos não-humanos.

O conceito de rizoma criado Deleuze a partir da concepção que Barthes é utilizado por Pierre Lévy (1993) como um novo paradigma para entender as redes hipertextuais e telemáticas. Resumindo, ao modo de Barthes, a rede não tem unidade orgânica (ex. início, meio e fim); na rede abundam muitas redes que atuam sem que nenhuma delas se imponha às demais; ela é uma espécie de galáxia mutante, com diversas vias de acesso, sem que nenhuma delas possa ser qualificada como principal; os códigos que mobiliza se estendem até onde a vista alcança, são indetermináveis. Estas características das redes podem ser aplicadas aos organismos, as tecnologias, aos dispositivos, mas também à subjetividade. Pois o pensamento rizomático é o pensamento que faz da conectividade seu único princípio. Somos uma rede de redes (multiplicidade), cada rede remete a outras redes de natureza diversa (heterogênese).

A grande maioria das observações apressadas que fazemos sobre as diferenças entre o hipertexto impresso e o hipertexto eletrônico só se coloca na medida as pessoas não se dão ao trabalho de pensar o livro como uma rede que supõe a biblioteca, por um lado, mas também ao ato de leitura, por outro, que pode ser encarado como pensamento rizomático. A

\footnotetext{
${ }^{2}$ Cf. Latour, Bruno (1994). Jamais fomos modernos. Rio de Janeiro: Ed.34.
} 
única grande mudança entre o livro impresso e o livro eletrônico é a velocidade de acesso de seus nós. Não é a toa que muitas das imagens utilizadas por Borges para falar dos livros, da biblioteca e da literatura se tornaram conceitos ou algoritmos que podemos utilizar para entender as mudanças que emergem com a hipertextualidade telemática.

Como mostra muito bem o filósofo Michel Serres (1998; 2000), existem apenas dois tipos de ciência, que se distinguem ponto a ponto, e cujos modelos são a geometria e a geografia. A primeira é a ciência do geral, a segunda a do particular. Uma privilegia o esquema, sempre virtual, a outra a cópia, reprodução do real. Enfim, uma cria, por meio de modelos, explicação e previsão, enquanto a outra cria, por meio de imagens, descrição e providência.

Para a ciência exata, dos modelos, o que caracteriza o real são as leis regulares, a ordem por detrás das aparências. Para a outra ciência, das imagens, o que caracteriza o real é a proliferação singular de detalhes, sua desordem. Enfim, o modelo faz desaparecer o particular, o detalhe, para ressaltar o mesmo, aqui e lá. A imagem, ao contrário, valoriza as multiplicidades que os modelos fazem desaparecer. De um lado, o esquema, a lei, o modelo, o inteligível, a arte da geometria. Do outro, a imagem, a reprodução, a cópia, o sensível, a arte da cartografia.

Ora, hoje, uma imagem fractal não pode se reduzir completamente a nenhuma das duas ciências apresentadas, por uma razão muito simples: a imagem fractal é fruto de uma nova ciência, onde o modelo e a imagem, o inteligível e o sensível, se dão as mãos para fabricar uma nova fenomenologia científica. Não geométrica, diz Serres (2000), certo,

porque reproduz as folhas das árvores e as crateras dos montes até os últimos detalhes; muito pouco geográfica, entretanto, porque não pode se fazer passar por quadro, retrato, mapa ou estampa e não representa nenhum lugar da terra em particular: ninguém nunca jamais viu, de fato, em lugar ou tempo algum, estas nuvens, estas montanhas, estas árvores... Saída toda armada de um computador e gerada por um algoritmo, uma verdadeira matemática a produziu.

De fato, a visualização computacional inaugurou uma era póskantiana, transformando as condições, práticas e teóricas, da experiência. Que nome dar a esta nova imagem, a esta nova representação, se ela abandona sua antiga função fenomenológica, uma vez que não é mais determinada pelos horizontes espaço-temporais de nossa experiência sensível? Que cor atribuir a um sinal recebido em faixas de ondas exteriores àquelas do espectro visível? Como qualificar o olhar quando ele faz face a uma imagem fractal, que se situa em uma zona intermediária entre o sensível e o inteligível? Quem vê, um outro órgão que o olho? Quem calcula, um outro órgão que o cérebro? Como chamar de imagem esta dimensão flutuante, entre o sensível e o inteligível? Sim, sem dúvida, entramos no campo da experiência do possível e do virtual.

É verdade que a simulação é um novo instrumento do pensamento científico, completamente diferente da lógica e das narrativas. Os sistemas dinâmicos de visualização científicos são uma poderosa ferramenta técnico-científica da atualidade. Sem ela, muitas das novas descobertas no campo da biotecnologia, da nanotecnologia, da astrofísica não poderiam ser realizadas, assim como as teorias não poderiam jamais se desenvolver sem a escrita e a lógica.

Ao mesmo tempo em que os indivíduos humanos são inteligentes, por possuírem estas capacidades (de perceber, de lembrar, de aprender, de imaginar e de raciocinar), não podemos esquecer que a inteligência possui uma dimensão coletiva ou social e técnica ou tecnológica, que em geral não são levadas em consideração. É impossível exercermos nossa inteligência independentemente dos sistemas semiológicos-línguas, linguagens e sistemas de signos e notações — bem como dos meios fala, escrita, livro, fotografia, cinema, multimídia, redes telemáticas - que herdamos através da cultura.

Desde sempre e por meio das tecnologias mais diversas, transformamos o mundo em informação: textos, desenhos, plantas, mapas, estampas, listas, gráficos, fotografias... Mas o que é informação? Segundo Bruno Latour, ${ }^{3}$ a informação não é um signo, mas uma relação estabelecida entre dois lugares, uma periferia e um centro, sob a condição que entre eles circule um veículo, uma inscrição. Por que transformar o mundo em informação? Por que a informação permite resolver de forma prática — por

\footnotetext{
${ }^{3}$ Ver o excelente texto de Bruno Latour (1996). Ces réseaux que la raison ignore: laboratoires, bibliothèques, collections. In M. Baratin \& C. Jacob (Orgs.). Le pouvoir des bibliothèques. Paris: Albin Michel.
} 
meio de operações de seleção, de extração, de redução e de inscrição - a contradição entre a presença e a ausência em um lugar. A informação não é uma forma no sentido aristotélico, mas uma relação prática e material entre dois lugares: o centro negocia com a periferia o que deve ser produzido para que a ação à distância sobre ela seja mais eficaz.

Desde que uma informação goza das vantagens do inscrito, do cálculo, da classificação, do superposto, disto que se pode inspecionar com o olhar, ela se torna comensurável com todas as outras inscrições pertencentes às realidades até então estranhas umas às outras. Compreendemos melhor, hoje, este fenômeno, porque utilizamos todos computadores e redes hipertextuais que nos permitem combinar, traduzir, integrar desenhos, textos, fotografias e gráficos, até então separados no espaço e no tempo.

A rede é a imobilidade necessária para recolher o que deve nela transitar. Consideremos a topologia especial destas redes. Redes de transformação fazem chegar aos centros de cálculos, por uma série de deslocamentos, um número exponencial de inscrições (informações). Estas informações circulam, mobilizando toda a rede sociotécnica disponível entre o centro e a periferia: esta é a única maneira de garantir a fidelidade e a precisão dos dados. Quando seguimos os seus traços, nós atravessamos a distinção usual entre as palavras e as coisas: não navegamos apenas no mundo, mas também através de diversas matérias de expressão.

Enfim, acreditamos que o atual sistema de produção de riquezas é assegurado por uma comunidade biopolítica (Negri, 2001). Todos, trabalhadores e não trabalhadores, participam do momento em que participam da produção de afeto e subjetividade. Essa riqueza é hoje, em grande parte, produzida pela atividade comunicacional na medida em que a comunicação é a dimensão essencial para a reprodução social geral. Por um lado hoje é cada vez mais importante preparar para o consumo, não esqueçamos que produção é imediatamente consumo e vice-versa. Por outro lado, o trabalho foi separado de sua potência política desde o momento em que o vínculo entre produção de riqueza e trabalho assalariado foi rompido. Em parte porque o trabalhador não precisa mais de capital fixo ou de ferramentas, pois a sua principal ferramenta é o cérebro ou a subjetividade (Negri, 2001). Eis porque não podemos pura e simplesmente abandonar o campo de lutas que é a comunicação sob o pretexto que comunicação é domínio do monstro da mídia sobre os zumbis prisioneiros.

\section{Referências}

Baudrillard, J. (1991). Simulacros e simulação. Lisboa: Relógio D’Água.

Deleuze, G. \& Guattari, F. (1995). Mil platôs (v. 1). Rio de Janeiro: Ed.34.

Guattari, F. (1992). Caosmose. Rio de Janeiro: Ed. 34.

Latour, B. (1996). Ces réseaux que la raison ignore: laboratoires, bibliotheques, collections. In M. Baratin \& C. Jacob (Orgs.). Le pouvoir des bibliothèques. Paris: Albin Michel.

Lévy, Pierre (1993). As tecnologias da inteligência. Rio de Janeiro: Ed.34.

Lyotard, J. F. (1990). A condição pós-moderna. Rio de Janeiro: José Olympio.

. (1989). O inumano. Lisboa: Editorial Estampa.

Negri, T. (2001). Exílio. São Paulo: Iluminuras.

Parente, A. (1993). Imagem-máquina. Rio de Janeiro: Ed. 34.

. (1999). O virtual e o hipertextual. Rio de Janeiro: Pazulin.

Serres, M. (1998). Atlas. Paris: Albin Michel.

. (Org.). (2000). Paysage das sciences. Paris: Le PommierFayard.

Virilio, P. (1994). A máquina de visão. Rio de Janeiro: José Olympio.

. (1993). A inércia polar. Lisboa: Dom Quixote. 


\section{CIVITAS, ${ }^{1}$ a Cidade Viva: ou do espaço de invenção do educador na escola}

Margarete Axt

\section{Um pouco sobre um certo desconforto...}

Ao agradecer o convite para participar dessa mesa que se propõe a pensar os modos de subjetivação operados pelas tecnologias no nosso contemporâneo, confesso uma pequena hesitação ao sentar para escrever o texto, até que parei para me perguntar o que era mesmo este desconforto para apenas narrar um projeto em andamento, refletindo sobre ele?

Ocorreu-me, então, que talvez independente de como eu viesse a narrar esta experimentação, a narrativa sofreria, de imediato, interpretações: interpretações que remeteriam a lugares outros que não os que eu imaginava. Termos como tecnologias digitais, formação continuada, comunicação a distância, criatividade, participação coletiva, eventualmente suscitariam interpretações remetendo a proposta, por exemplo, a ações de governo, ${ }^{2}$ não mais, apenas, a serviço de regimes

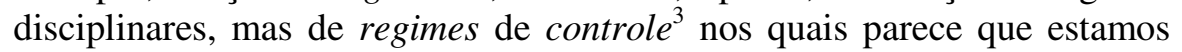
cada vez mais imersos desde o advento dos vários processos de

${ }^{1}$ Projeto CIVITAS - Cidades Virtuais: Tecnologias para Aprendizagem e Simulação, apoiado pelo CNPq, processo $\mathrm{n}^{\circ}$ 55.1639/01-6. A equipe de pesquisadores responsável pelo projeto, sob minha coordenação, é composta por Dra. Rosa Maria Vicari, Dra. Carime R. Elias; Mestres Magali Longhi, Marcio Martins; doutorandos Leandro M. Andrade. Evandro Alves; os bolsistas atuais Marcelo Laserra, Michelle Freimuller, Felipe Drago, Helena Xavier, José Francisco Annonni. Leandro Gallina, Diego Gonçalves; o colaborador Andrei Thomaz.

${ }^{2}$ Governo, no sentido amplo de técnicas e procedimentos destinados a dirigir a conduta dos homens (Foucault, 1997).

3 Para Edson Passetti (2002) é a "participação contínua que dá sentido ao controle contínuo". Para ele, "vivemos numa sociedade de controle que se afirma, antes de tudo, como sociedade de difusão de direitos e que encontrou no multiculturalismo a sua forma mais atroz. Veio dar direitos a todos num momento em que o corpo deixou de ser parte conjugada da máquina energética. $O$ direito não é mais acesso, mas condição para a continuidade dos súditos reinventores de soberanias desterretorializantes. São convocados pelos fluxos produtivos eletrônicos que não requerem mais o corpo inteiro, mas apenas a inteligência". (p.136). globalização em curso... Nesta luta entre uma decantada, mas principalmente desgastada noção de autonomia ${ }^{4}$ do sujeito e um regime do controle que aparenta confiscar a seu serviço a inteligência ativa e participante, a capacidade de integração social e a própria educação/ formação continuada e permanente, a pergunta ficaria, então, sendo "qual o espaço de invenção que ainda resta para o ser humano?" e, mais especificamente, "qual o espaço de invenção para o educador na escola”?

Ao mesmo tempo, a própria preocupação com as possíveis interpretações se esvai, fazendo furo nos dispositivos de controle, uma vez que não há como imputar um controle total sobre o trabalho de interpretação, ou por outra, não há como estancar a produção de sentido, além do que o sentido é sempre "duplo sentido"; nos diz Deleuze:

Não é nem ao mesmo tempo nem relativamente à mesma coisa que eu sou mais jovem e mais velho, mas é ao mesmo tempo que me torno um e outro e pela mesma relação (1998, p.36).

Conectado ao pensamento de Foucault, Deleuze considera que sempre pertencemos a dispositivos e nele agimos; que, porém, há coexistência concomitante entre diferentes linhas de um dispositivo, compondo pelo menos dois grupos, as linhas de estratificação ou de sedimentação - as linhas duras reguladoras, normatizadoras das opiniões, das crenças do senso comum - e as linhas de ruptura ou de fissura, as linhas da criatividade, brotando qual rizoma na instância micropolítica, sem que se possa precisar como nem quando nem por que,

linhas de subjetivação [que] parecem particularmente capazes de traçar caminhos de criação, que não cessam de fracassar, mas que também, na mesma medida, são retomados, modificados, até a ruptura do antigo dispositivo (Deleuze, 1996, p.92).

Não por acaso, Michel Pêcheux, que também tem em Foucault ${ }^{5}$ (mais Althusser) uma das bases de sustentação para a sua Análise do Discurso, considera que Estado e Instituições funcionam o mais frequentem ente como polos privilegiados de resposta a uma necessidade

\footnotetext{
${ }^{4}$ V. Piaget, 1973; Freire, 1997.

${ }^{5}$ V. Foucault, 2000.
} 
imperiosa, que temos enquanto sujeitos pragmáticos, de universos discursivos logicamente estabilizados. Diz Pêcheux:

o sujeito pragmático - isto é, cada um de nós, os "simples particulares" face às diversas urgências de sua vida - tem por si mesmo uma imperiosa necessidade de homogeneidade lógica. [...] De nada serve negar essa necessidade (desejo) [...] de um mundo "semanticamente normal", isto é normatizado [que] começa com a relação de cada um com seu próprio corpo e seus arredores imediatos (e antes de tudo com a distribuição de bons e maus objetos) [...] (1997, pp.36-37).

Ao mesmo tempo, o autor irá considerar que esta homogeneidade lógica discursiva é, no entanto, sempre atravessada por equívocos, podendo os mesmos derivarem da ambiguidade contida em determinadas formulações - termos, expressões, como por exemplo as que referimos acima - ainda não estabilizadas, na medida em que circulam por diferentes domínios discursivos... O próprio da língua, pondera o autor, é a equivocidade, o que produz, de saída, uma divisão discursiva entre dois espaços: o da manipulação de significações estabilizadas, normatizadas e o das transformações do sentido, escapando a qualquer norma estabelecida $a$ priori, sendo que é na fronteira entre ambos espaços que existe toda uma zona intermediária de processos discursivos oscilantes, nos quais objetos podem, ou não, ter esta ou aquela propriedade, os acontecimentos podem ter, ou não, lugar segundo as construções discursivas nas quais se encontram inscritos os enunciados que sustentam esses objetos e acontecimentos. Estes espaços são considerados pelo autor como estando constituídos de uma pluralidade contraditória de filiações históricas (através das palavras, das imagens, das narrativas, dos discursos, dos textos etc.), gerando sentidos diferentes, de modo que ninguém nunca pode estar muito seguro a propósito do que se fala. De qualquer maneira, para Pêcheux, todo discurso marca a possibilidade de uma desestruturaçãoreestruturação das redes e trajetos discursivos: todo discurso é um índice potencial de uma agitação nas filiações sócio-históricas de identificação, na medida em que ele constitui ao mesmo tempo um efeito dessas filiações e um trabalho (mais ou menos consciente) de deslocamento no seu espaço não há nunca identificação plenamente bem sucedida, isto é, ligação sóciohistórica que não seja afetada de uma maneira ou outra por uma "infelicidade" de interpretação, interpretação definida aqui como tomada de posição que surge, sendo reconhecida como tal e assumida, não negada.

Portanto, já despojada da ilusão de um controle sobre as interpretações dos sujeitos particulares a respeito do projeto e as decorrentes experimentações, mas, por isso mesmo, também confortada pela ideia de que todo dispositivo não é homogêneo, sendo sempre, de algum modo, desequilibrado pelo heterogêneo, atravessado pela ambiguidade do equívoco, logo sujeito a rupturas e a transformações, aproveito o tempo e o espaço disponibilizado para narrar o CIVITAS.

\section{Um pouco sobre as experimentações...}

O CIVITAS é um projeto na forma de experimentações em sala de aula envolvendo professoras e alunos do Ensino fundamental ( $3^{\mathrm{a}}$ série), equipe de pesquisadores e bolsistas, além de estudantes da pós-graduação meus orientandos e de estudantes da graduação em pedagogia, em uma disciplina optativa... Um projeto que tem uma expectativa de poder pensar, em conjunto com professoras e crianças, a Cidade Viva; e que pretende constituir, ao lado de outros, um espaço alternativo de invenção na escola... Um projeto que integra as instâncias de Pesquisa, Docência no Ensino Superior, e Extensão, e que se desenvolve, simultaneamente, em três tempos:

1. Primeiro tempo, o tempo da Pesquisa voltada à programação, e comportando dois momentos:

a) $\mathrm{O}$ da modelização de um editor de simulação, ${ }^{6}$ em que pesquisadores e bolsistas estão programando módulos para compor um sistema - frame - que permita que grupos de participantes (crianças) construam juntos uma cidade virtual, desde a conformação do terreno, a definição de áreas urbanas e rurais, até o planejamento e a urbanização de uma área, a construção de moradias e outros prédios. O projeto está sendo concebido segundo uma ótica sistêmica complexa e deverá incorporar

${ }^{6}$ Encontra-se em desenvolvimento, os seguintes módulos: MAPPA (editor de terrenos); EDITTORE (editor de objetos); CITTA (gerenciador da Cidade); MAGA VITTA (agente inteligente de interface). 
apenas regras que digam respeito às leis de preservação ambiental e à constituição de uma ecologia de convivência relacional homem-sociedadenatureza-ambiente urbano; uma ecologia de cuidado com a vida, implicando questionamento e posicionamento (est)ético. Esta programação, enquanto são elaboradas as interfaces de interação, sofre os efeitos das concepções das crianças de Ensino Fundamental, recolhidas através da discussão com as mesmas sobre como imaginam a vida na cidade. Mas reciprocamente, as professoras também já estão modificando a sua prática docente, com vistas a futuramente incorporarem o editor de simulação na dinâmica de sala de aula. Nesse sentido, as decisões em cadeia, do prefeito, da secretaria de Educação, das direções das escolas, mas principalmente das professoras, de participarem e de se comprometerem com o projeto criaram um vazio de espaço — um espaço liso ${ }^{7}$ - que precisa ser preenchido, preenchido com percursos, percursos que precisam ser inventados.

b) O outro momento da programação é de uma biblioteca virtual, em que pesquisadores e bolsistas, a partir das investigações sobre quais demandas as crianças do Ensino Fundamental têm (e terão) para suas incursões no mundo das cidades, estão construindo interfaces lúdicas de acesso à biblioteca, incitando à exploração do material didático em forma de texto ou multimídia e de links para sites educacionais interessantes a essa faixa etária. Também as produções das crianças e de suas professoras serão (e já estão sendo) armazenadas nesta biblioteca, com o cuidado devido à preservação das respectivas autorias, ficando disponível para consultas na web por todos os interessados. Esta proposta prevê ainda um ambiente de introdução à língua inglesa para crianças, tendo em vista possibilitar a sua navegação por sites educacionais em inglês. $\mathrm{O}$ projeto da biblioteca nasceu como complementação ao projeto CIVITAS, quando a equipe verificou in loco uma certa condição de precariedade das bibliotecas escolares.

2. O segundo tempo é o tempo das atividades de Docência na graduação em Pedagogia, na forma de uma disciplina opcional — Estudos em Linguagem Interação e Cognição — que criamos para favorecer a

\footnotetext{
${ }^{7}$ Deleuze e Guattari (1997).
}

participação dos estudantes em projetos específicos, coordenados pelo LELIC/UFRGS $^{8}$ (projetos dos pesquisadores do laboratório, ou orientandos ou docentes). Neste semestre e, provavelmente nos próximos, os estudantes entram em contato com crianças — as do projeto, pela via do forchat, uma ferramenta de comunicação e interação desenvolvida por nós e que procura favorecer reuniões virtuais de discussão não hierárquica de tópicos; mas entram em contato também com outras crianças, na forma de entrevistas individuais presenciais para identificar-lhes concepções, linguagem, dinâmica de comunicação, saberes e conhecimentos, interesses, curiosidades... Enfim, compreendêlas na dinâmica da vida e do aprender. Este material é avaliado pelos estudantes à luz de estudos teóricos; os estudantes também analisam livros didáticos em relação aos conteúdos do currículo e, a partir de uma concepção de currículo com eixo sobre a aprendizagem, propõem textos provocativos a respeito de tópicos relacionados ao currículo, para serem postados na biblioteca. Por enquanto os textos são ainda verbais escritos. Mais adiante, há uma ideia de desenvolver com os estudantes a possibilidade de textos multimidiáticos (talvez em dois semestres).

3. O terceiro tempo é então o tempo das atividades de Extensão, que prevê o suporte teórico-metodológico às professoras de Ensino Fundamental envolvidas no projeto, em consonância com a ideia de formação continuada, em serviço. A equipe de pesquisadores e bolsistas do projeto não trabalha diretamente com as crianças em sala de aula, a não ser pela comunicação no ambiente virtual, quando então acompanham as professoras no suporte à interação. O grupo (professoras e sempre pelo menos um membro da equipe do projeto) se reúne semanalmente para realizar estudos de caráter teórico-metodológico, a partir do que, analisam e avaliam conjuntamente os próprios relatos sobre suas atividades em sala de aula e as relações professor-aluno; concomitantemente aprendem a utilizar as ferramentas disponibilizadas

${ }^{8}$ Laboratório de Estudos em Linguagem Interação e Cognição, sob minha coordenação, está situado na Faculdade de Educação. Programa de Pós-Graduação em Educação, onde desenvolve suas pesquisas. O LELIC também está integrado ao Centro Interdisciplinar De Tecnologias na Educação, Programa de Pós-Graduação em Informática na Educação. www.lelic.ufrgs.br (em construção). Atualmente, a prof ${ }^{a}$. responsável por esta disciplina é a $\operatorname{Dr}^{\mathrm{a}}$ Carime Rossi Elias. 
também às crianças - o objetivo é que as professoras possam cooperativamente propor e amparar mudanças e inovações na dinâmica das práticas pedagógicas, de modo que, em sala de aula, invistam na disponibilização de múltiplas tecnologias e de sua exploração inventiva por parte das crianças, colocando a grade curricular a serviço da metodologia ativa com eixo sobre a aprendizagem. Neste escopo, as tecnologias do virtual e o próprio editor de simulação serão apenas parte do conjunto de opções a serem colocadas à disposição de uma metodologia ativa e criativa de aprendizagem na sala de aula.

\section{Um pouco sobre a Cidade Viva como espaço de invenção...}

As cidades virtuais - estando propostas no âmbito das tecnologias digitais (mas não excluindo cidades com materiais e suportes convencionais concretos) - supõem uma construção cooperativa, em tempo real, tanto síncrono quanto assíncrono, pelos vários grupos de crianças. É, portanto, de se esperar que precisem discutir regras de construção, desde a definição do terreno, a aprovação de um plano diretor em função do próprio terreno, a distribuição de lotes para a construção de casas e prédios, até a definição de uma legislação de preservação ambiental, envolvendo a organização social, política e jurídica da cidade, a memória cultural-histórica, a posição econômico-geográfica relativa (na região, no país e no plano mundial) e o estabelecimento de contratos sociais coordenando as relações de sociabilidade entre os cidadãos, ou seja, entre elas as crianças.

Essas combinações, definições e determinações conjuntas requerem uma organização cooperativa que pode se realizar em dois níveis: (i) na sala de aula, presencialmente, entre os alunos de uma mesma turma, o que já vem sendo feito; (ii) no ambiente virtual, pela via da interação no forchat usando a plataforma AVENCCA, entre as turmas, o que começa a ser implementado. As discussões e combinações podem contar (e contam sempre) com a participação das professoras, como mais uma voz a contribuir para os acertos de conjunto.

A busca de informações e de outros elementos para subsidiar as construções nos variados níveis de interesse das crianças (da infraestrutura urbana, da estrutura organizacional propriamente dita e suas relações com o ambiente natural-social, urbano-rural, histórico-cultural...) já vem sendo dinamizada nas mais diversas modalidades, embora ainda com algum vagar. De qualquer maneira, e em que pese as limitações, as crianças já começam a participar ativamente, junto com as professoras, na definição das diferentes possibilidades de busca - visitas, saídas a campo, entrevistas com pessoas da família, do bairro e da vida pública na cidade, pesquisa em fontes documentais, vídeos, filmes, músicas, biblioteca virtual...

Os registros seguem ao sabor da criatividade das crianças, especialmente na forma de apontamentos em blocos de notas, fotografias e coleção de fragmentos de materiais, ou exposição de objetos e relíquias.

Abrindo um parêntese, cabe lembrar que este é um projeto-piloto em que pesquisadores, professoras e crianças encontram-se envolvidos na invenção de caminhos possíveis, precisando também conquistar a confiança e a anuência de pais, direção de escola e secretaria municipal de educação, o que pode não se dar, sempre, com a presteza esperada. De outro lado, uma mudança paradigmática deslocando abruptamente o foco de uma perspectiva sobre o ensino para uma perspectiva sobre a aprendizagem, não deixa de enfrentar alguns sérios desafios, na medida em que tal mudança precisa se fazer inserida no interior dos já considerados dispositivos de regulação e normatização, em meio a opiniões e crenças do senso comum - e isso, tanto no que se refere ao âmbito da ação institucional, quanto no que concerne ao uso discursivo da linguagem; de modo que todo o movimento de mudança está sujeito, o tempo todo, às armadilhas dos processos parafrásticos-identificatórios característicos dos dispositivos institucionais e discursivos em funcionamento. $\mathrm{O}$ processo de mudança é, por isso mesmo, lento, exigindo consistência teórica e vigilância metodológica, da parte do grupo de professoras, o que só pode ser obtido à custa de dedicação e de estudo compartilhado, fazendo trabalhar, pelos processos de dispersão (mais ou menos conscientes) os deslocamentos de perspectiva, uma vez que concordamos de que não há, no interior de qualquer dispositivo, institucional ou discursivo, uma identificação plenamente bem sucedida. ${ }^{9}$ ${ }^{9}$ Trago a título de exemplo, excertos de um texto escrito por uma das professoras, Marlise
Antoni, e que foi ao ar como parte de seu relatório, cujo título é "Tudo começou assim..." 
Fechando o parêntese e voltando à narrativa, falta colocar que a produção das crianças com base nos resultados das buscas pode se expressar pela via das diferentes tecnologias convencionais e/ou digitais disponíveis, através de inúmeros e variados modos de composição, ${ }^{10}$ num plano de expressão artística; ou mediante descrições e narrativas erigidas sobre um plano de referência determinado, nos moldes dos relatórios técnico-científicos, implicando discussão de resultados; ou ainda, num plano de imanência do pensamento, pelo exercício de construção conceitual com desdobramentos sobre os modos de existência enquanto balizados por uma est(ética) de cuidado com a vida, sem maiores incentivos e apelos a uma ordem transcendente superior ou a outros vínculos de natureza heteronômica.

O objetivo é favorecer, de um lado, a produção de textos, não apenas verbais escritos, mas multimidiáticos, através da produção de páginas-web suportadas pela plataforma AVENCCA e postadas na biblioteca virtual que, assim alimentada, deverá crescer como um organismo vivo em função da contribuição dos seus associados. Mas, para além do suporte eletrônico, e mais que isso, a produção pode e deve se expressar simultaneamente pela via também de outros suportes - maquetes com miscelânea de materiais trazidos pelas próprias crianças, blocos de construção, mapas, desenhos, pinturas, esculturas, jornal escrito ou falado, apresentações expositivas ao

[...] Iniciaram-se as reuniões coordenadas pelo professor Márcio que foi a ponte entre a UFRGS e nós professores. Estudos, questionamentos, forças foram surgindo e eu juntamente com a minha turma procurando alternativas, caminhos, tentando criar situações de aprendizagem. O projeto foi avançando, fomos aprendendo e juntos fomos descobrindo que tinha alternativas e a indisciplina começou a deixar lugar para o interesse, a pesquisa, a alegria, a cumplicidade entre os alunos, ninguém queria faltar às quartas-feiras dia da informática. O desafio gera expectativas e angústias em relação ao resultado final, mas ao mesmo tempo é muito agradável e gratificante. Durante este período me senti muito desafiada e consequentemente insegura, mas no momento em que as dificuldades iam sendo superadas me sentia aliviada e mais segura. [...] este projeto abriu caminhos para a construção e produção de conhecimentos, tendo o professor um papel muito importante a desempenhar nesse processo, repensando sobre a sua teoria, e sua postura [...] Diante disso, penso que devemos ter um bom embasamento teórico, propiciando uma prática pedagógica crítica, para que o aluno consiga adquirir a sua autonomia. [...].

${ }^{10}$ Deleuze e Guattari (1997) propõem três modos de pensamento - o da arte, o da filosofia e o da ciência - que se erigem respectivamente sobre planos de composição estética, planos de imanência do pensamento e planos de referência do conhecimento. vivo, demonstrações de experimentos, sons musicais, poemas, dramatizações... Enfim, o que a imaginação sugerir... E tudo isso, mesmo quando já estiver disponível o sistema de programação modular para editar por simulação a cidade digital (o que ainda não é o caso), uma vez que tal cidade irá exigir, para a sua construção, a construção correspondente de conhecimento específico, bem como a potencialização de outros saberes.

\section{Um pouco das nossas motivações teóricas...}

O projeto, na confecção, teve Sua referência articulada às teorias da complexidade, em especial Piaget; à filosofia da linguagem tal como proposta por Bakhtin; e à filosofia da diferença como exposta em Deleuze e Guattari. Em especial, esta apresentação, de hoje, busca nos últimos autores a inspiração maior para caracterizar as experimentações em andamento, no que é ajudada, em alguns momentos, pela Análise do Discurso francesa, fase $3-$ AD3 de Pêcheux.

Concentrando o foco sobre a ideia de cidade, vemo-la, de um lado (e na esteira de Deleuze e Guattari ${ }^{11}$ ), como uma mistura de corpos e vividos, encharcados de afecções e percepções, e, ao mesmo tempo, refém do senso comum - crenças, opiniões e clichês - que naturaliza o vivido; e refém de informações encapsuladas genéricas, fragmentadas e descontextualizadas, abrindo caminho para fazer funcionar, pela via do hábito e dos modelos de recognição, os inúmeros dispositivos de reprodução: palavras de ordem geradas a partir dos conteúdos da grade curricular, e também os demais dispositivos escolares e socioculturais ativados... ${ }^{12}$

\footnotetext{
${ }_{11}^{11}$ A partir de Deleuze e Guattari (1997a; 1997b); e Deleuze (1996; 1998).

12 Como um de muitos exemplos que nos atravessam o tempo todo em nosso cotidiano (escolar, mas também familiar), trago um pequeno texto de um aluno, sobre o "MEIO AMBIENTE", no qual podemos nos reconhecer com facilidade, e que traz claramente as marcas dos dispositivos de regulação e de normatização: "NAO DEIXAR ÁGUA PARADA, PARA NAO CRIAR MOSQUITO DA DENGUE". Vejamos outro texto com as mesmas marcas de impessoalidade (uso do infinitivo), palavras de ordem, normativas e com um típico sentido de interdição, tão comum em nosso cotidiano: "O trânsito. Não pode ter briga no recreio. Não pode empurrar na fila. Não pode jogar lixo no chão". A comparação
} 
Mas de outro lado, esta mesma característica de mistura de corpos e vividos aponta para a cidade como um catalisador em potencial dos modos de ser-sentir, de conhecer, de conceber-fabricar, abrindo para as possibilidades do pensamento como heterogênese; nesse sentido, viversentir-conhecer-fabricar a cidade estaria produzindo linhas de subjetividade abertas à hibridação fazendo deslizar de sensações, para relações e variações conceituais, ou vice-versa. ${ }^{13}$

A cidade como uma espécie de ponto intensivo, momentâneo e fugaz, abriria à captura, sempre provisória, de forças e fluxos, durações e velocidades, formas e limites - corporais, em movimento, misturados potencializando efeitos de sentido - incorporais - que aí encontrariam, obrigatoriamente, pela via do compartilhamento no coletivo, condições de passagem para o nível da expressão. Supõe-se, neste caso, uma emergência de processos de subjetivação muito particulares, incitando a um transbordamento do sentido-pensamento constituído no encontro com a cidade, verdadeiro acontecimento em busca de expressão, mas instigando

desses escritos com o texto que segue na próxima nota nos dá bem a dimensão do quanto a desses escritos com o texto que segue na próxima nota nos dá bem
interdição é capaz de sufocar qualquer possibilidade de invenção.

${ }^{13}$ A título de comparação com o exemplo anterior, e de ilustração desses processos de expressão que acabam por se atualizar sobre mais de um plano de suporte ao pensamento, simultaneamente, a partir de sucessivos deslocamentos, trazemos parte do projeto do aluno Douglas Luiz Weber, da Escola Benno Breunig, quando ao relatar um "Trabalho sobre a Água", colocou no ar o seguinte texto, com visível marca de estilo autoral: "A minha maquete foi elaborada através da água. Porque eu escutei muitas histórias dos meus avós, que era muito difícil mover máquinas naquele tempo. Eles sempre me contavam que tudo ele faziam através da água. Por isso resolvi mostrar minha maquete mais ou menos no tempo dos meus avós. Eu fiz um moinho que se movimentava através da água, que gerava energia elétrica para as pequenas propriedades e movia moinhos na fabricação de farinhas, e tocava algumas mais cerrarias que beneficiavam tabuas para a construção de casas" (o texto permanece fiel ao original, sem correções). A sua maquete, pode-se dizer que é uma verdadeira invenção, sobre um plano de composição, mas recortado, também por um plano de referência, produzindo, dentre outras, variáveis importantes para construção de conhecimento em física. Já o texto apresenta um interessante trabalho de interpretação, que se compõe com a explicação do invento. Ainda no texto, pode-se dizer que estão presentes marcas de afectos e perceptos compondo sensações que, como leitores, podemos capturar nos sentidos de amor às histórias de vida da família; mas também marcas do estabelecimento de relações objetivas dando conta de um pequeno ecosistema, além construção de uma concepção que introduz o tempo no conceito de cidade. também à interpretação pelo retorno sobre si com tomada de posição, e à explicação adensada por processos de objetivação do pensamento.

A cidade pode ser definida como coexistência: coexiste com a casa, o corpo, o micro e o macrocosmo. E se é feita de afecções e percepções, mesmo que um tanto desordenadas, ela também é tentativamente regulada, disciplinada, normatizada, controlada pelas opiniões, pelas palavras de ordem, pelos dispositivos reguladores, normativos. É preciso que a cidade seja problematizada, problematizada na instância do coletivo, desafiando o grupo ao traçado de planos, planos que então, de um lado, constituiriam a condição de passagem de percepções e afecções subjetivas e indiscerníveis ao nível de expressão do pensamento; mas também, de outro lado, planos produzindo, a um só e mesmo tempo, linhas de fuga com novas possibilidades de territorialização, desafiando as linhas duras e sedimentadas no interior dos dispositivos em jogo. Planos múltiplos, que tendo a cidade como suporte, dariam sustentação a experimentações desdobradas em, pelo menos, três aspectos, dando vazão (embora de maneira ainda muito tímida e incipiente) a sensações, relações, coordenações e distinções, enquanto efeitos de sentido objetivados: são experimentações, que pudemos identificar como sendo de ordem estéticosensível, características da arte, incitando o sentir naquilo que vibra e ressoa; experimentações de ordem funcional, próprias ao conhecer científico, exercitando limites, relações e coordenações; experimentações de ordem conceptual, catalisando a construção do conceito complexo, enquanto um conjunto de variações de sentido, não separáveis umas das outras: sentido como efeito das variações de contexto (e este por sua vez mistura, sempre outra, de corpos e vividos), abrindo fendas no conceito cristalizado e fechado, refém do senso comum, das crenças, das opiniões, da informação encapsulada, das normatizações homogeneizantes.

Na continuidade, a cidade traçada em múltiplos planos insinua-se crescentemente polissêmica e multivocal, abrigando uma multiplicidade de universos de sentidos: no entremeio dialógico desses universos em movimento, sentidos descolam-se dos corpos e vividos, deslizando de seus universos de origem e fecundando-se mutuamente, engendrando os próprios planos sobre os quais se organizam as experimentações. 
É então, de cada vez, em cada "pequeno lugar de encontro"14 entre universos de sentido, em que sentidos se confrontam ou se entrelaçam... que a mim parece que emerge um mínimo espaço intervalar entre um sentido, e outro, e mais outro: um mínimo espaço abrindo uma espera no tempo, diminuta bifurcação em forma de rizoma, que produz uma escolha! É com estes frágeis hiatos bifurcantes - esperas no tempo produzindo escolhas, delicadas criações, erigidas sobre planos de conhecimento referencial, construção conceitual e composição estética - que podemos contar para fender o círculo fechado das opiniões e das palavras de ordem, dos dispositivos a serviço da recognição, da regulação, do controle, em que pese sabermos que, mesmo então, nesses hiatos, uma bifurcação pode escolher justamente o sentido do senso comum.

De maneira que não há trégua nem para pesquisadores, nem para professores, nem mesmo para as crianças, quando se trata, nestas diminutas, mas múltiplas esperas no tempo, de explorar a produção de escolhas, estendendo-as o quanto possível, numa dimensão est(ética) de cuidado com o sentido, de cuidado com a vida!

\section{Referências}

Axt, M. (1998). Linguagem e telemática: tecnologias para inventarconstruir conhecimento. Educação, Subjetividade \& Poder, Porto Alegre, 5, 5, 20-30. [Republicado in Pellanda, N. \& Pellanda, E. C. (Orgs.). (2000). Ciberespaço: um hipertexto com Pierre Lévy. Porto Alegre: Artes e Ofícios.]

Bakhtin, M. (1997). Estética da criação verbal. São Paulo: Martins Fontes.

Deleuze, G. (1998). Lógica do sentido. São Paulo: Perspectiva.

Deleuze, G. (1996). O mistério de Ariana. Lisboa: Veja.

Deleuze, G. \& Guattari, F. (1997). Mil Platôs; capitalismo e esquizofrenia (v. 5). São Paulo: Ed. 34.

Deleuze, G. \& Guattari, F. (1997). O que é Filosofia? São Paulo: Ed.34.
Foucault, M. (2000). A ordem do discurso. São Paulo: Loyola.

Freire, P. (1997). Pedagogia da autonomia; saberes necessários à prática educativa. Rio de Janeiro: Paz e Terra.

Passeti, E. (2002). Anarquismos e Sociedade de Controle. In M. Rago, L. L. Orlandi \& A. Veiga-Neto (Orgs.). Imagens de Foucault $e$ Deleuze; ressonâncias nietzschianas. Rio de Janeiro: DP\&A.

Pêcheux, M. (1997). O discurso, estrutura ou acontecimento. Campinas: Pontes.

Piaget, J. (1997). Estudos sociológicos. Rio de Janeiro: Forense.

${ }^{14}$ Cf. Axt (1998). 


\section{Ser humano versus máquina: quem produz quem?}

\section{Pedrinho A. Guareschi}

O sinal dos tempos hoje, é que vivemos um tempo de sinais! Sábio o que consegue se deter, nos dias de hoje, para admirar esse fantástico e formidável fenômeno de um mundo cada vez mais simbólico, cuja realidade passa a ser quase que um "segundo andar", rarefeita, fluida, escorregadia, em uma mutação constante.

O mais instigador e provocante de tudo isso, contudo, é que o ser humano não passa imune e incólume diante desse fenômeno: ele é personagem central nesse drama-tragédia, um protagonista que age e reage, sofre e tenta intervir, caminha e luta na trajetória do tempo. Admirável mistério o ser humano. Sempre em construção, interminável, infinito, um microcosmos sobre quem somos, como é o mundo que nos rodeia. E hoje nos perguntamos até mesmo se podemos fazer a pergunta sobre essa relação. Milhares de respostas já foram dadas e muitas outras continuam a surgir. Há algo de inevitável e ao mesmo tempo misterioso no que diz respeito à presença do ser humano nesse mundo: novas facetas da realidade vão se revelando e desdobrando diante de nós, com a diferença que hoje essas mudanças são precipitadas e estonteantes.

É sobre essa relação ser humano e mundo, na sua relaçãoincorporação, que desejo refletir, com cuidado e humildade, a partir do tema acima e de considerações feitas por Margareth Axt e André Parente. Pretendo me fixar em três pontos interligados. Primeiramente, uma rápida discussão, básica, sociológico-econômica, sobre o fenômeno da Informação/Comunicação hoje. A seguir, procuro recuperar alguns apartes já oferecidos sobre o tema, mas que passaram desapercebidos e que mereceriam uma nova atenção. Finalmente, pretendo oferecer um jeito de poder, hoje, lidar com essa problemática, ao menos para conseguirmos falar e discutir sobre ela: a questão da "relação".
1. A informação como modo de desenvolvimento: uma chave de entendimento da economia moderna

Em cada formação social, em cada modo de produção, isto é, na maneira como conseguimos as coisas para viver e nos reproduzirmos, há também um modo de desenvolvimento principal. Esse modo desenvolvimento é definido pelo elemento fundamental à promoção da produtividade no modo de produção específico. No modo agrário, a fonte de incremento de excedente resulta dos aumentos quantitativos de mão-deobra e dos recursos naturais, em particular a terra. No modo desenvolvimento industrial, a principal fonte de produtividade reside na introdução de novas formas de energia e na capacidade de descentralização do uso de energia ao longo do processo produtivo e de circulação. Hoje, no modo informacional, a fonte de produtividade encontra-se na tecnologia de geração de conhecimentos, de processamento da informação e da comunicação de símbolos. Apesar de conhecimentos e informação serem elementos cruciais em todos os modos de desenvolvimento, o que é específico ao modo informacional é a ação de conhecimentos sobre os próprios conhecimentos como principal fonte de produtividade; é a melhoria da tecnologia do processamento de informação como fonte de produtividade (Castells, 1999, pp.33-34).

Pode-se constatar com facilidade que quem detém a informação hoje, detém também a chave de desenvolvimento. Tudo hoje passa pela informação. Se quero comprar um computador, já faço meu pedido através da Internet. O pedido é registrado praticamente em tempo real. A partir do pedido, o computador começa a ser fabricado. Todas as peças, mesmo a embalagem e o suporte material, são construídos através de máquinas que são por sua vez controladas por outros computadores baseados na informação. Em doze horas todo o computador é construído e montado, da maneira específica e singular como eu pedi. A única demora é a entrega, mas mesmo ali as distancias estão sendo supressas, na medida do possível, novamente através da informação/comunicação. Os jornais que eram antes impressos num determinado espaço geográfico e podiam levar horas para chegar aos leitores, são agora enviados, eletronicamente, a determinados locais para serem impressos ali e mais rapidamente distribuídos, pois as distâncias se reduziram. Isso se eu quiser um exemplar impresso, caso 
contrário, posso ler na Europa os jornais de Porto Alegre antes de eles serem aqui mesmo impressos, através dos correios eletrônicos.

Ampliando o quadro, podemos afirmar que vivemos hoje uma sociedade midiada, uma cultura midiada (Thompson, 1995, 1998). Todas as instâncias de uma sociedade, a partir da economia, passando pela educação. pela religião, pela política (Thompson. 2002) etc., são incompreensíveis hoje fora da informação/comunicação.

Mas o ponto que quero enfrentar, a partir dessas constatações básicas, é mais desafiante e sério: e o ser humano? Como entra ele nesse jogo de forças e relações? Como nos compreendemos e como nos situamos diante de tais desafios quase paradoxais?

Essa sobre essa questão que continuo esta elaboração.

\section{Informação/comunicação e ser humano}

Diante de uma realidade cada vez mais definida e formatada pela informação/comunicação, permaneceria o ser humano imune a tal situação? Certamente não, e já de há muito, inúmeros pensadores se preocuparam com esse tema.

Gostaria de retomar e, até certo ponto, recuperar aqui as contribuições de McLuhan sobre essa questão, apresentadas já na década de 1960. Tais aportes sofreram uma espécie de eclipse ao redor da década de 1980, mas são agora retomadas, de maneira surpreendente, a partir de meados da década de 1990. Tem-se a impressão que aquilo que McLuhan dizia, de maneira quase profética, estão agora se constituindo em um instigante e eficaz referencial teórico de compreensão da informação e da comunicação nos dias atuais.

A tese central dos livros de McLuhan $(1962,1964,1969)$ é a de que o tipo de comunicação conforma (institui, dá os contornos) a um determinado tipo de ser humano. Analisa três estágios principais, onde se constata o predomínio de um determinado tipo de comunicação e como tal prática comunicativa influencia na constituição do ser humano.

O primeiro estágio dessa comunicação é denominado por McLuhan como sendo o mundo tribal. O estilo principal de comunicação era fundamentalmente o acústico, baseado no falar e no ouvir. Evidentemente, tal tipo de comunicação (e isso é importante) exigia a presença física das pessoas e a existência de comunidades humanas. O espaço da comunicação era até onde se podia ouvir a fala de alguém. $O$ autor mostra que tal comunicação se prestava à construção e existência de um ser humano pluridimensional, abrangente, pois o acústico nos propicia falar e ouvir a partir de múltiplas direções. Um ser humano capaz de fazer várias coisas ao mesmo tempo, no dizer do autor, "de rir e chorar ao mesmo tempo".

O segundo estágio é denominado como o mundo destribalizado. Em tal estágio predomina o tipo de comunicação baseado na escrita e na leitura. E ao ser alfabetizado, o ser humano introjeta as ideias de ordem, sucessão, linearidade, construindo um ser humano unidirecional, à semelhança das linhas de montagem, um ser humano incapaz de fazer mais que uma coisa simultaneamente. Em tal tipo de comunicação a comunidade é dispensada e são incentivadas e reforçadas práticas individualistas e isoladas: alguém sozinho, fechado em um quarto, pode-se comunicar através da escrita e da leitura. McLuhan mostra também que é nessa época, na história, que predominam os absolutismos de estado, por um lado, com a supressão da organização e mobilização populares; o ser humano se vê sozinho, sem defesa, diante dos estados Leviatã.

Interessante constatar que tais afirmações de McLuhan se vêem, até certo ponto, confirmadas por psicólogos que se preocupam em ajudar as pessoas a ler com mais rapidez. As causas principais de as pessoas lerem com vagar deve-se ao fato de estarmos acostumados, devido à alfabetização, a ver apenas uma coisa depois da outra, uma letra depois da outra, uma palavra após outra. No momento em que tentamos ver várias palavras ao mesmo tempo, uma frase inteira, ou uma coluna toda do texto, podemos progredir com muito maior rapidez na apropriação do texto. Por que podemos ver uma imagem num lance de olhos e gravar tal imagem e não podemos fazer o mesmo com uma frase, um parágrafo, ou até mesmo com parte de uma página? A tudo isso se agrega o costume de soletrarmos mentalmente as palavras, o que torna a leitura ainda mais demorada. No momento em que tentarmos, então, vermos várias coisas ao mesmo tempo e não nos preocuparmos em soletrar mentalmente as palavras, poderemos ler com muito mais rapidez. Alguns analistas, baseados em McLuhan, tentam explicar também o fenômeno instigante, constatado nas guerras 
napoleônicas, de que os alfabetizados aprendiam a marchar em pelotões, regimentos, etc, com apenas algumas horas de treinamento, ao passo que os analfabetos demoravam dias e semanas para incorporar a "ordem unida". A explicação dada por esses analistas é que os alfabetizados introjetaram, com a alfabetização, as ideias de regularidade, ordem, sucessão, equidistância. Se tal explicação não é definitiva, é ao menos provocante e nos instiga a aprofundar fenômenos tão singulares.

Finalmente, na análise de McLuhan, chegamos a um terceiro estágio na história da comunicação, denominado por ele como o mundo retribalizado. É o tipo de comunicação que se faz presente com a criação dos meios de comunicação eletrônicos e a junção da imagem, texto e som. O mundo se transforma, na sua expressão original, em uma aldeia global e o ser humano passa a receber diariamente milhares de bombardeios comunicativos eletrônicos, provindos de todas as direções.

A primeira e importante constatação desse tipo de comunicação é a de que a comunicação assume um direcionamento vertical e de mão única, por um lado e massiva e profundamente envolvente, por outro. As pessoas se transformam em receptores quase inertes e passivos, com sérias possibilidades de serem manipuladas, sem tempo, às vezes, e sem possibilidades de retroagirem. É a isso que Thompson (1998) chama de quase-interação midiada. Os atores da mídia se transformam em novos indivíduos dentro de nossas casas e passamos, em muitas situações, a nos relacionarmos mais com eles do que com os próprios membros da família. Não é difícil constatar que muitas crianças e adolescentes, hoje, passam mais tempo em contato com personagens midiáticos do que com os próprios pais e irmãos. Mas é importante darmo-nos conta, como veremos no ponto a seguir, que consequências tal tipo de "comunicação" acarreta. E isso terá a ver diretamente com o tema que nos estamos propondo a discutir nessa apresentação, isto é, os novos modos de subjetivação.

Há, contudo, uma outra consideração importante que se torna necessário discutir para podermos compreender melhor o último ponto: é a mudança que está se dando, a partir da informação/comunicação, nos dias de hoje, em três dimensões fundamentais que se apresentam à consciência do ser humano e que nos marcam profundamente: a dimensão da distância do espaço e do tempo. Tais dimensões, em nosso mundo marcado pelo avanço profundo das novas tecnologias, modificam seu sentido, ou melhor, passam a ser percebidas diferentemente pelas pessoas, influenciando, de maneiras diferenciadas, a construção de sua subjetividade, sua subjetivação.

No que se refere à distância, ela passa hoje a ser encurtada, o mundo se torna uma aldeia. Tomamos café em um continente, almoçamos em um segundo e jantamos em um terceiro. Vencemos a velocidade da terra e chegamos antes da hora de partida. A terra se sente comprimida. As informações saem e chegam, aos turbilhões, sem intervalos, num tempo que se esvaece e se restaura em segundos. Tudo hoje é "penúltimo" — o último está para chegar a qualquer momento. Normal, pois, que os equilíbrios estremeçam. Dados, sons, imagens: tudo se propaga ininterruptamente.

O espaço se transforma profundamente. Cria-se um novo espaço, o ciberespaço, praticamente infinito e, paradoxalmente, sem ocupar um lugar. É a grande invenção das novas tecnologias da informação e da comunicação. Bibliotecas inteiras são armazenadas em trilhões de bits que cabem em pequenos discos.

Mas é na dimensão do tempo que se notam as mais profundas transformações. Ninguém jamais conseguiu definir o tempo. Perguntado sobre ele, Santo Agostinho responde: "Se não me perguntarem o que seja o tempo, eu sei o que é; mas se me perguntarem, já não sei”. É que o tempo é a percepção que temos do tempo. E o percebemos hoje como um tempo precipitado, acelerado (Gurvitch, 1964) presentificado. Mas o mais preocupante disso tudo é que o "aqui" e o "agora" passam a assumir valores de "realidade" e de "verdade": o que existe é apenas o aqui e agora, o que é verdade é apenas o aqui e agora. Os assessores de comunicação dos governantes não estão mais interessados em desmentir fatos: o segredo é substituir os fatos. Devido à força e importância dessa presentificação do tempo, se algo é noticiado, se está na mídia, essa é a realidade e essa é a verdade.

Mas há algo ainda mais provocador nessa percepção do tempo hoje: inúmeros filósofos, pesquisadores, analistas e psicólogos que se debruçam sobre essa realidade do tempo hoje, estão se dando conta da existência de determinados fatores, bem sutis e delicados, mas nem por isso menos centrais e importantes, presentes na comunicação em nossos dias. 
Misteriosa nossa vida em sociedade em hoje! Eles estão se dando conta da importância e das consequências da intensidade comunicacional em que vivemos. Chegaram até a criar novos termos, para designar essa nova realidade. Um autor belga, Joel de Rosnay (1997) diz que vivemos hoje uma época de "cronofagia", isto é, uma época em que temos necessidade de nos alimentar do "tempo", do "novo", uma época em que muitos se transformam em devoradores de coisas novas. Na mesma linha de ideias, fala-se hoje de um novo tipo de adição, a "dataholics", que consiste em nos viciarmos em notícias, em coisas novas. Não conseguimos mais viver sem buscar incessantemente as últimas novidades. Podemos verificar isso em nós mesmos, quando, por exemplo, ligamos a televisão e vemos uma notícia que já tínhamos visto ontem. Nossa reação imediata é: "Isso eu já vi ontem! Será que não há nada de novo hoje?" Que significa isso? Tal estado de ânimo sugere, no entender dos analistas, que muitos sofrem de uma ansiedade e necessidade de buscar continuamente um novo manjar. Antigamente as notícias de uma semana eram ainda "novas". Hoje, o de ontem é antigo e ultrapassado. Isso pode levar a criar ansiedades nas pessoas, dentro de um tempo acelerado, um tempo precipitado.

Não é fora de propósito trazer ainda aqui algumas reflexões questionadoras de Donna Haraway, em seu Manifesto ciborgue: ciência, tecnologia e feminismo-socialista no final do século XX (apud Kunzru e Haraway, 2000). Dentro desse amplo contexto, ela sugere que estamos diante de "quebras de fronteiras" (p.44) e discute três delas: a fronteira entre o humano e o animal, entre o animal-humano (organismo) e a máquina e entre o físico e o não físico (para ela um subconjunto da segunda fronteira). Desenvolve seu pensamento mostrando que em nossa época as máquinas tornaram ambígua a diferença entre o natural e o artificial, entre a mente e o corpo, entre aquilo que se autocria e aquilo que é externamente criado. $\mathrm{Na}$ sua expressão, "as máquinas são perturbadoramente vivas e nós mesmos assustadoramente inertes" (2000, p.46). Ao discutir as dominações, mostra que elas não funcionam mais por meio da medicalização e da normalização, mas através de redes, do redesenho da comunicação, da administração do estresse. "A normalização cede lugar à automação, à absoluta redundância” (2000, p.112).

Há ainda outros psicólogos que discutem essa relação entre ser humano e as tecnologias da informação/comunicação e como isso influencia os modos de subjetivação, como por exemplo Carvalho (2000). O próprio Guattari (1992), ao discutir a produção de subjetividade, apontava que "as produções semióticas da mídia, da informática, da telemática, da robótica, etc.” não podem ser tomadas fora da subjetividade psicológica, pois

as máquinas tecnológicas da informação e a comunicação operam no núcleo da subjetividade humana, não apenas no seio das suas memórias, da sua inteligência, mas também da sua sensibilidade, dos seus afetos, dos seus fantasmas inconscientes (1992, p.14).

\section{Como, então, nos aproximarmos do ser humano?}

Entendo e assumo o ser humano como construído historicamente através de milhões de relações. Seleciono dois conceitos para melhor compreender o processo de contínua construção e subjetivação do ser humano: o de singularidade, com o qual procuro mostrar que somos seres absolutamente únicos, irrepetíveis; e o de subjetividade, com o qual designo o conteúdo desse ser humano, o estofo com que somos construídos. Nas peripécias da vida, nos milhões de relações que estabelecemos, recortamos singularmente partes diferentes do tecido social, com o qual vamos tecendo e construindo a colcha de retalhos de nossa subjetividade, nesse processo infinito de subjetivação, cujas maneiras e estratégias vão se transformando sem cessar e hoje, através das novas tecnologias de informação e comunicação, assumem facetas novas e desafiadoras.

Como tentar compreender e ser solidário com o ser humano em tal situação? Não vejo, na medida em que reflito e medito, a partir tanto da tradição ocidental como a oriental, outra alternativa que não seja a da reflexão crítica sobre quem somos, por que somos o que somos, por que o que nos rodeia é assim. E é a partir disso que defino a consciência, baseado nas considerações de Lane (1981), numa época de recuperação de uma psicologia social crítica: "Somente quando formos capazes de, a partir de um questionamento desse tipo, descobrirmos as razões de por que somos o que somos e do contexto... é que podemos desenvolver uma autêntica consciência crítica". O que constitui a consciência é a resposta que consigo a esses questionamentos. É importante dar-se conta de que consciência não é nenhum epifenômeno, que não existe consciência em si, corporificada. Ela é sempre consciência $d e$, por isso sempre relacional e social. Fazemos 
parte, construímos e somos construídos por inúmeras práticas relacionais, numa dialética constante e infinita.

Num passo adiante, a partir da reflexão acima, pode-se arriscar dizer que é essa dinâmica relacional de "prendermos" e "sermos presas", de mútua compreensão (cum - prehendere= segurar junto), que podemos nos aproximar desse algo misterioso a que chamamos liberdade e arriscar dizer que é esse processo da consciência que nos leva à liberdade, que só é livre quem tem consciência. E que é ainda a partir dessa reflexão, sobre o processo de construção da consciência que nos leva à liberdade, que é possível podermos chegar a falar de uma verdadeira responsabilidade, que vem de dentro, do que há de mais profundo e misterioso no ser humano: sua consciência e liberdade. A responsabilidade não é entendida e posta em prática, então, a partir de fora, das normas, das pressões e coações externas, mas é fruto de um processo de consciência que nos liberta. É a partir daí que podemos também dar conta das inúmeras "práticas", de todo tipo, que continuamente tentam nos formar e conformar; é essa reflexão crítica que nos garante a liberdade, a singularidade, a possibilidade de criação e de transformação.

São as novas práticas informacionais e comunicacionais que devem se tornar, hoje, tema de nossa contínua reflexão. Em um momento histórico em que as dimensões mais próximas de nós, como a distância, o espaço e o tempo, os a priori kantianos, se modificam e tomam novos sentidos, é urgente que nos deixemos admirar por tais práticas e façamos a pergunta corajosa, libertadora e responsável: Quem somos nós? Quem continuamos a ser? Como estamos sendo construídos e reconstruídos incessantemente por fluxos e fenômenos cambiantes, misteriosos, que, como todo mistério, são impossíveis de serem vistos, tocados, falados?

\section{Referências}

Castells, M. (1999). A Era da Informação: economia, sociedade e cultura (v.1: A sociedade em rede). Rio de Janeiro: Paz e Terra.

Carvalho, P. S. (2000). Humanos x computadores: o que a Psicologia tem a ver com isso? In E. Sayeg (Org.). Psicologia e Informática (pp.1529). São Paulo: Casa do Psicólogo.
Guattari, F. (1992). Caosmose: um novo paradigma estético. Rio de Janeiro: Ed. 34.

Gurvitch, G. (1964). The spectrum of social time. London: Dordrecht.

Kunzru, H., Haraway, D. \& Silva, T. T. t2000). Antropologia do ciborgue - As vertigens do pós-humano. Belo Horizonte: Autêntica.

Lane, S. (1981). Que é Psicologia Social? S.Paulo: Brasiliense.

McLuhan, M. (1962). The Gutemberg Galaxy: the making of topographic man. Toronto: Universidade de Toronto.

McLuhan, M. (1964). Os meios de comunicação como extensões do homem. São Paulo: Cultrix.

McLuhan, M. (1969). O meio são as massa-gens. Rio de Janeiro: Record.

Rosnay, J. (1997). La France et le cybermonde. In Le Monde Diplomatique, 521, 28.

Thompson, J. (1995). Ideologia e cultura moderna - Teoria social crítica na Era dos Meios de Comunicação de Massa. Petrópolis: Vozes.

Thompson, J. (1998). Mídia e modernidade - Uma teoria social da mídia. Petrópolis: Vozes.

Thompson, J. (2002). O escândalo político — Poder e visibilidade na Era da Mídia. Petrópolis: Vozes. 


\section{SIMPÓSIO 2 - REDES SOLIDÁRIAS, AUTOGESTÃO E SOLIDARIEDADE}

\section{Redes solidárias, autogestão e solidariedade}

Peter Spink

Quando recebi o convite dos organizadores de nosso encontro para participar desta mesa sobre a temática de redes solidárias, autogestão e solidariedade, tenho que ser honesto e sincero e dizer que foi um momento de prazer e preocupação ao mesmo tempo. Prazer porque foi um estímulo para organizar uma série de reflexões sobre estes temas e de ouvir e ler muitas pessoas a respeito; desde já quero agradecer os membros do núcleo de organização e ação social da PUC-SP que muito participaram destas discussões com suas ideias, dissertações e teses. Mas também foi um momento de preocupação, porque a discussão sobre as redes solidárias, a autogestão e a solidariedade faz parte da busca de alternativas em torno de uma economia mais solidária num lugar sócio e economicamente confuso e contraditório chamado "Brasil". País este cujo perfil atual é bem resumido na seguinte frase de um relatório internacional': "a América Latina é talvez o continente mais desigual no mundo e o Brasil é o país mais desigual deste continente". A preocupação vem do tamanho do desafio que esta frase representa e com a nossa capa cidade coletiva de resposta,

Será que a psicologia social concebida como um ramo da psicologia, tem a capacidade e competência de contribuir efetivamente para modificar e transformar esta situação? Quero levantar a possibilidade que a psicologia é cada vez mais irrelevante para os nossos trabalhos, seja nas suas vertentes ortodoxas ou críticas. Precisamos, talvez, concentrar nossos esforços na construção de uma outra psicologia social, esta vez entendida como disciplina acadêmica; posição também compartilhada por outros e reforçada por ninguém menos do que Serge Moscovici poucas semanas atrás em São Paulo.

\footnotetext{
${ }^{1}$ Desigualdades na América Latina: rompendo com a história. Banco Mundial, 2003.
}

\section{Desigualdade, exclusão social e pobreza}

Espero, honestamente, que ninguém aqui precisa ser informado sobre a situação no país, mas também penso que é sempre bom lembrar algumas das características das múltiplas desigualdades e pobrezas dentro de um pano de fundo geral de exclusão social. Em outras palavras, o tamanho do desafio. As informações a seguir são de fonte do IBGE, Fundação Seade, Dieese, OPAS e Banco mundial.

Em termos de distribuição de renda, os $10 \%$ mais ricos da população Brasileira concentram quase $50 \%$ de toda a renda do país; ficando o noventa por cento restante com a outra metade. Na outra extremidade, os $10 \%$ mais pobres são donos de somente $1 \%$ da renda. Há entre nós, pelo menos 50 milhões de pessoas vivendo com renda familiar per capita de menos de 80 reais por mês; isto quer dizer pelo menos $30 \%$ da população. São somente $15 \%$ das famílias brasileiras que tem uma renda familiar de mais de quatro mil reais - suficiente para entrar no mercado de bens de consumo e interessar o capitalismo internacional.

A taxa de desemprego nas grandes cidades brasileiras está atualmente variando entre 15 e $20 \%$ em cidades como Porto Alegre, São Paulo, Belo horizonte, chegando até quase 30\% em Salvador. Entretanto estas porcentagens são médias. Se as abrimos em relação a gênero, descobrimos que a taxa de desemprego das mulheres é maior do que dos homens e se abrimos em termos de etnia, descobrimos que os níveis de desemprego entre a população negra são maiores do que entre a população branca.

Aliás, é necessário - até obrigatório - num país com tal grau de desigualdade como o Brasil, olhar com bastante suspeita qualquer estatística apresentada em termos de uma média populacional geral. Por exemplo, não há duvida que a mortalidade infantil para menores de cinco anos tem diminuído no país. Mas não podemos esquecer, que as crianças que nascem nos $20 \%$ das famílias mais ricas, têm entre três a cinco vezes mais possibilidade de sobrevivência nos seus primeiros cinco anos, do que as crianças que nascem nos $20 \%$ de famílias mais pobres.

Alfabetização é um outro grande jogo de esconde-esconde, culpado por tudo e constantemente refém do jogo dos indicadores. Pergunto: o que 
adianta dizer que a taxa de analfabetismo tanto para homens quanto para mulheres já baixou para $13 \%$ quando a variação entre a zona urbana e a zona rural é de três vezes e a variação geral entre as regiões e de quatro vezes; ou seja, de $7 \%$ até $26 \%$ na média geral? Igualmente pergunto, o que adianta falar em alfabetização sem lembrar os argumentos de Paulo Freire (2001) que aprender a ler e escrever era somente necessário porque o acesso ao poder, às oportunidades e aos processos de transformação no nosso tipo de sociedade tornou tais competências essenciais? A habilidade de por em prática a leitura e a escrita para melhorar suas condições de vida é chamado pela UNESCO de analfabetismo funcional.

Não poder agir efetivamente num mundo de formulários e documentos é o dia a dia de $30 \%$ de brasileiros; $24 \%$ na zona urbana e $54 \%$ na zona rural. Em termos regionais estas porcentagens chegam até quase 90\% em algumas áreas rurais; condições perfeitas para a atuação dos gatos do trabalho escravo.

Podemos continuar com mais e mais estatísticas, sobre a segurança pública, sobre a habitação, mas prefiro terminar com somente duas. $\mathrm{O}$ primeiro vem de um excelente estudo recente da FASE (2003) no Rio de Janeiro sobre Novos Marcos para Relações Raciais. Utilizando os dados do censo e outras fontes, buscaram recalcular o IDH para três Brasis. O primeiro é o Brasil geral, o Brasil da média, que ocupa o septuagésimo nono lugar no mundo. O segundo é o Brasil branco, que ocupa o quadragésimo nono lugar e o terceiro é o Brasil negro que ocupa o centésimo oitavo lugar (quase sessenta lugares mais para baixo).

O segundo vem de nosso trabalho no programa Gestão Pública e Cidadania na Fundação Getúlio Vargas de São Paulo onde desde 1996 estamos trabalhando na identificação e disseminação de iniciativas de governos subnacionais brasileiros (estados, municípios e os governos próprios dos povos indígenas), que não somente melhoram os serviços públicos mas geram um impacto positivo na construção da cidadania. Até hoje temos mais de seis mil experiências registradas oriundas de quase 800 municípios, além de estados e muitos dos povos originários. Ao olhar estas experiências, vemos que são provenientes de municípios de todos os tamanhos, de todas as partes do País; de partidos políticos os mais variados e sobre tópicos e questões que se colocam no dia a dia da vida local. Podemos falar de municípios onde entre $75 \%$ a $90 \%$ da população está sendo atendida nos seus domicílios pelas equipes de saúde local; onde questões complicadas como violência contra a mulher, geração de emprego e renda, recuperação ambiental e muitas outras estão sendo trabalhadas com bastante criatividade. Há trabalhos que interconectam gerações; outros que interconectam saberes e muitos que simplesmente conectam pessoas e começam a resolver os problemas do dia a dia. ${ }^{2}$

\section{A psicologia social e os psicólogos sociais}

Sem dúvida há psicólogos e psicólogos sociais que entendem as implicações destes dados e há também psicólogos e psicólogos sociais participando numa parte das mais de 6.000 experiências diferentes. $\mathrm{O}$ problema do desafio não é falta de ativismo, como as presenças em dois eventos bem demonstram. O primeiro foi o I Congresso Brasileiro de Psicologia: Ciência e Profissão organizado em São Paulo pelo Fórum das Entidades Nacionais da Psicologia Brasileira, que contou com dez mil pessoas entre psicólogos atuantes, professores e estudantes e mais de 2.00 trabalhos apresentados e discutidos. O segundo é este nosso encontro da ABRAPSO, que não para de crescer com mais de 2.000 trabalhos diretamente relacionados às questões sociais da atualidade.

Então, por que eu devo ficar preocupado? Estou preocupado porque tenho dúvida se as ações estão sendo elaboradas como reação ao desafio que as estatísticas delineiam, estão acontecendo porque os psicólogos e psicólogas sociais estão desenvolvendo conceitos, ideias e práticas que aumentam coletivamente a sua capacidade contributiva; ou porque eles e elas são pessoas - como qualquer outra - que são capazes de se envolver nos problemas do cotidiano, utilizando para isso nada mais do que os saberes do dia a dia e um senso forte de "solidariedade".

A segunda possibilidade não é, a priori, um problema. Milhares de pessoas fazem isso todos os dias ao redor do mundo sem nenhuma preparação ou titulação acadêmica. A prática de solidariedade é uma consequência da vida em comunidade. Entretanto esperamos, imagino, que

${ }^{2}$ http://inovando.fgvsp.br ou escreve para o Programa Gestão Pública e Cidadania na FGVEAESP. 
os campos de conhecimento acadêmico sirvam para uma contribuição adicional, agregando mais saberes aos saberes existentes, ajudando a ampliar as possibilidades de uma vida digna. Se não, o que estamos fazendo aqui? No caso de um campo de conhecimento, podemos até escolher agir propositadamente a partir da prática porque assumimos uma postura específica de pesquisa-ação participativa em relação à construção de saberes e conhecimentos. Mas mesmo assim, haverá momentos de debate, de consolidação de ideias sobre ação com um retorno para as múltiplas comunidades envolvidas.

Temo, entretanto, que os "psicólogos enquanto pessoas" estão utilizando suas habilidades práticas mundanas, fazendo "o que bem entendem de maneira sincera" porque a psicologia e a psicologia social são incapazes de fazer uma contribuição efetiva.

Sem dúvida, alguém pode arguir que, tanto faz, tudo acaba sendo útil de alguma maneira. Entretanto não estamos tratando dos processos aleatórios de partículas subatômicas ou do caos criativo do universo, mas de pessoas. Parece-me que, enquanto grupo acadêmico-profissional, temos uma obrigação moral de sermos muito claros sobre o que fazemos e como fazemos diante do desafio que eu delineei no início, porque se não tomamos muito cuidado, há uma grande probabilidade de acabarmos por reproduzir as próprias práticas de desigualdade e de exclusão. O mundo não se divide facilmente entre o bem e o mal e se somos parte da solução podemos facilmente virar parte do problema também.

\section{A mais valia da pobreza}

Gostaria de aprofundar este ponto, voltando no tempo para o ano 1965 quando Saul Alinsky foi convidado a escrever um artigo na revista Norte Americana Social Issues da Society for the Psychological Study of Social Issues - a ABRAPSO de lá. Alinsky (1965) foi um ativista que iniciou seu trabalho em Chicago durante a década de 1930 e criou a expressão "organizações de base popular" (peoples organizations) para se referir às organizações autóctones e independentes cuja capacidade de pressão era essencial para tornar a democracia mais substantiva. Mestre das táticas de pressão, Alinsky foi mentor, entre outras, de pessoas como Cesar Chaves — o líder dos trabalhadores migrantes na Califórnia (Horwitt,
1989). O convite foi para comentar sobre o principal programa de política social da época nos Estados Unidos: a guerra contra pobreza do partido democrata. Cito parte da introdução (Alinksy, 1965, pp.41-47) que não é nada gentil:

Ouvi uma voz alta que proclamava da Casa Branca. 'Enfim a Grande Sociedade chegou aos homens. Eles passarão a viver decentemente e com dignidade. A Grande Sociedade apagará a pobreza; haverá um fim à guerra, e à discriminação e falta de cuidado médico e desemprego; pois a velha ordem chegou ao fim' [...] O programa de combate à pobreza foi lançado publicamente embrulhado com uma nobreza de propósito embora com uma certa dedicação que cheirava a falsa piedade. A não ser que ocorram mudanças drásticas quanto à direção, razão e administração, o programa de combate à pobreza pode muito bem vir a ser o pior erro político e bumerangue da presente administração. Se alguma vez existiu um programa que demandasse uma administração agressiva, partidária e sem medo de controvérsias, este programa é o da pobreza. É necessário que um programa do tipo tenha como argumento que pobreza inclui pobreza de poder, além de pobreza econômica. Já vimos isto na luta por direitos cívicos, além da luta por empregos. [...]

[.... Hoje, o programa de combate à pobreza emerge como uma enorme oportunidade de enriquecimento político [....] Em cidade após cidade, encontramos a Prefeitura sentada em cima da pilha de fundos destinados à pobreza. Seus Comitês para a Oportunidade Econômica têm uma maioria de funcionários pagos ou fiéis ao partido. Estes seguem uma política de identificação para definir programas positivos e negativos, e líderes comunitários positivos e negativos. A distinção é simples. Positivo significa fazer o que a Prefeitura manda, manter-se na linha, ser "responsável" (à Prefeitura, é claro). Negativo significa ter um comportamento nãoortodoxo; ser tão subversivo a ponto de pensar por conta própria, colocar como prioridade primária os moradores de sua comunidade, ser independente e irreverente em relação à Prefeitura.[...]

[...] Estes fundos para a pobreza são usados então para sufocar lideranças militantes independentes e organizações de ação que têm surgido para dar aos pobres a sua cota de poder. Isto é, a organização dos próprios pobres para que possam tomar o seu lugar correto e legítimo na cena pública... 
Espero que ninguém aqui seja tão antiamericano ou igualmente tão ufanista para imaginar que isso não pode acontecer aqui. Pode e acontece.

\section{A reprodução da desigualdade}

O problema para o qual Alinsky aponta não pare somente no lado político, mas continua em relação aos gastos em si, é o que alguns de nós temos chamado a "mais valia" da pobreza; o equivalente no campo social da indústria da seca. Se você ainda tem dúvida se pode acontecer aqui, é só lembrar os muitos artigos que saem nos cadernos de emprego e nas revistas semanais sobre as grandes oportunidades de emprego no terceiro setor; ou refletir sobre as somas de dinheiro gastos em programas de capacitação. "Gastos", quer dizer, pagas para os professores e agentes profissionais de desenvolvimento.

Nem a boa vontade e muita menos a cultura acadêmica, são garantias de uma ação moralmente coerente; não há um ISO 9000 de contribuições sociais. Precisamos perguntar, de maneira simples e honesta, se estamos usando ao máximo a potencialidade deste "matrix social" que é uma disciplina acadêmica, na busca das ideias, práticas, conceitos e quem sabe, até de teorias que aumentam a nossa capacidade de ajuda; que ampliam as possibilidades de transformação.

\section{A centralidade da comunidade}

Podemos olhar isso a partir de uma das questões subjacente ao tema desta mesa - a discussão sobre comunidade feita na filosofia moral. Presente entre os gregos, a temática volta com força no final do período medieval onde aparece na discussão sobre liberdade, governo e estado quando, como argumenta o historiador de ideais Quentin Skinner (1998), liberdade vai perder terreno para o liberalismo e a discussão sobre autogoverno vai perder lugar para o Estado-Nação.

Ainda hoje é uma asserção fundamental do liberalismo que a comunidade é o produto da associação de indivíduos independentes e que o valor dessa comunidade deve ser estimado pela justiça dos termos segundo os quais esses indivíduos se associam (esta, por exemplo, é a posição de John Rawls (1997) no livro intitulado Uma Teoria de Justiça). Em contra argumento, a filosofia moral comunitária atual expressa por autores como Michael Sandel e Alasdair MacIntyre (1998) sustenta que não faz sentido pensar numa comunidade dessa forma, porque a própria existência de indivíduos capazes de estabelecer acordos para formarem associações, ou de concordarem quanto aos termos dos acordos, pressupõe a existência de uma comunidade. Portanto qualquer explicação da comunidade que tente mostrá-la como o produto do acordo de indivíduos pré-sociais acabará por ser incoerente, porque a tais pessoas acabará por faltar a capacidade para deliberar, refletir, escolher.

Mesmo este resumo bastante simples dos argumentos demonstra o problema da relação entre a psicologia e a psicologia social. Ora, se você acredita que a comunidade é produto da associação de indivíduos independentes, um número de consequências segue, entre estas: o próprio indivíduo independente com a sua subjetividade autônoma e distinta, a necessidade de pessoas aprenderem a viver em comunidade e de ter um Estado que garanta as regras e contratos.

Se é assim que você pensa, é também provável que você aceita a incapacidade das pessoas se retirarem da mundanidade do cotidiano, a não ser quando lideradas por um partido ou um agente externo que as "conscientiza". Portanto, torna-se natural, nesta perspectiva, que as pessoas devam receber aulas sobre a cidadania, que sejam informadas sobre o que é a "verdadeira" autogestão ou o cooperativismo "autentico" e que sejam ensinadas a se organizar. Esta é a perspectiva liberal, que pode ser também tanto na psicologia ortodoxa quanto numa boa parte da psicologia crítica. É uma consequência daquilo que Adorno (1967) apontou: a alienação mútua da psicologia e da sociologia cada um em relação à outra e em consequência, consigo mesmo. Pior ainda, se só há indivíduos, você vai precisar de um Estado ou pelo menos um governo suficientemente forte para manter a ordem.

Entretanto, esta perspectiva é incapaz de explicar porque no Brasil, há mais de 10 milhões de trabalhadores já identificados como sendo associados e auto-organizados de alguma maneira na informalidade e na autogestão, incluído aí: pescadores, catadores de papel, agricultores familiares, caminhoneiros, profissionais do sexo e muitos outros. Estes 10 milhões são a ponta do iceberg dos milhares de postos de trabalho que compõem o trabalho dito informal. 
Igualmente, esta perspectiva é incapaz de explicar processos sociais como o da ANTEAG aonde a discussão teórica sobre autogestão veio muito depois da ação; ou de muitos outros exemplos de processos autóctones em partes diferentes do país onde pessoas agem coletivamente na busca de soluções.

Para explicá-las é necessário reconhecer a validade do pressuposto que nascemos em comunidade, nas socialidades e materialidades do dia a dia cujas linguagens de ação são repletas de palavras organizativas de uso constante; formando uma referência contínua a nossa competência coletiva. Há inúmeras lutas pela hegemonia sobre estas noções organizativas, mas elas fazem parte da competência coletiva - não há dúvida. Nascer em comunidade é presumir uma capacidade coletiva de autogestão, que antecede e prescinde de um governo ou um Estado.

Mas não é esta a perspectiva que encontramos nos livros de texto da psicologia e da psicologia social. Ao contrário, desde que Floyd Allport, no seu famoso livro de texto de Psicologia Social de 1924, agradeceu à Sociologia por suas contribuições, mas avisou que a psicologia social já poderia ficar com os psicólogos, o que encontramos é um afunilamento cada vez maior na direção de uma psicologia de um indivíduo, que vive num contexto social cada vez mais amorfo. Os dois (o indivíduo e o contexto) tem muito pouco a ver um com outro, assim justificando os comentários foucaultianos de Nicholas Rose (1998) sobre as ciências "psi”, enquanto fenômenos sociais de governamentalidade; uma ciência que ao enfatizar o indivíduo que age calculativamente de acordo com seus interesses próprios, acaba por desassociar-nos de nós mesmos.

Espero que agora a minha preocupação comece a ficar mais claro. Redes solidárias, autogestão e solidariedade podem formar parte de uma frente libertária de pensamento transformador, mas podem igualmente formar parte de uma frente liberal de desublimação repressiva e reprodutiva que ao mesmo tempo em que aparentemente abre, reprime e aliena.

Por exemplo, por que as elites podem ter empresas e os pobres têm que ter cooperativas? Por que as elites podem ter contratos milionários de coleta de resíduos sólidos e o pobre tem que se contentar com o lixo seletivo e a reciclagem? Por que as elites têm acesso aos processos de licitação pública e os pobres têm que aceitar a sobrevivência marginal de costurar roupa para o bazar da esquina? Por que as elites têm acesso ao sistema de financiamento habitacional sem pegar na enxada, quando os pobres, para ter o mesmo privilégio, precisam trabalhar em mutirão?

Palavras duras — sim — mas não por acaso. Nos estudos que fizemos sobre um número significativo de experiências de ação local na redução da pobreza, foram poucos os governos encontrados que entenderam a necessidade de intervir nas cadeias produtivas, ou de criar mecanismos favoráveis às oportunidades de comercialização; de assumir uma ação afirmativa e de intervir nos processos de reprodução da desigualdade (Camarotti e Spink, 2003). Construir uma economia solidária não é constituir uma organização e deixá-la sozinha para tentar sobreviver num mercado hostil. Ao contrário, a economia solidária se refere a relações e ao fortalecimento de múltiplas interconexões entre organizações diferentes; interconexões de produção, de consumo, de escoamento, de crédito, de conhecimento. É a busca do adensamento gradativo de uma malha de possibilidades solidárias, forte o suficiente para impor seus interesses e defendê-los.

Muitas vezes encontramos investimentos substanciais na capacitação individual e na criação de novas organizações, diagnósticos e planos incluindo aulas expositivas sobre a "verdadeira autogestão" ou o "cooperativismo correto", sem que em nenhum momento, alguém pergunte — "quando vocês querem fazer algo, como vocês fazem? Como vocês se organizam por aqui?".

A questão do "cooperativismo autêntico" é um clássico exemplo do problema que estamos discutindo. Não há nada num mundo socialmente construído que seja "autêntico" ou "correto"; isso é simples manipulação ideológica na busca da hegemonia sobre o dia a dia.

A cidade têxtil de Rochdale, lugar dos pioneiros do cooperativismo, é hoje parte da área metropolitana de Manchester no norte da Inglaterra e foi um dos berços de vários movimentos de autoajuda provenientes do socialismo utópico. Para os trabalhadores de Rochdale o cooperativismo incluiu o consumo, a produção, o emprego e o crédito. Não havia nada de "mágico" na sua organização. Esta resultara de um processo já aprofundado no movimento trabalhista e seu modelo de associação foi copiado e ampliado a partir das Sociedades mútuas para apoio em casos de 
doença ou morte. Uma das primeiras descrições da Sociedade dos Pioneiros Equitativos de Rochdale (Rochdale Society of Equitable Pioneers) foi escrita em 1844, o ano da fundação da sociedade e da abertura da famosa Loja (Cooperative Provision Store), por George Holyoake. Seu título: “Autoajuda pelo povo" (Self help by the people ${ }^{3}$ ). Comentando os documentos produzidos pelos membros da associação, Holyoake anota que seus planos eram de não somente estabelecer uma loja, mas de construir casas, de abrir fábricas, de ter terras produtivas, de manter um hotel para as pessoas que não tomaram álcool e:

Tão cedo quanto é praticável, esta Sociedade deve proceder para organizar os poderes de produção, distribuição, educação e governo; ou, em outras palavras, de estabelecer uma colônia no país [uma comuna, como diríamos hoje] de interesses unidos, ou ajudar outras sociedades a estabelecer tais colônias.

Não é difícil ver que se tratou de um processo contra-hegemônico e emancipatório; de um confronto claro com os modelos existentes através da construção de novas materialidades e socialidades (Law e Mol. 1995). Um contraste considerável com os debates que assistimos sobre por que as cooperativas de consumo não são "verdadeiras cooperativas", ou por que "cooperativas de produção somente são válidas quando utilizam a autogestão".

Se olharmos cada uma das palavras do título de nossa mesa, encontramos os mesmos processos e conflitos. As redes solidárias, por exemplo, podem servir para transformar desigualdades, quebrar barreiras de escoamento comercial e garantir acesso às informações como também podem servir para reproduzir relações desiguais. Por exemplo, as redes de troca em Buenos Aires tiveram grande êxito até o momento em que atraíram a atenção da classe média, cujos bens de troca valiam mais do que os outros.

Agora se buscarmos entender a noção de rede na psicologia social, pouco encontraremos. Entretanto, o termo foi e continua sendo uma peça fundamental na construção de uma antropologia da ação que buscou explicar não como o mundo é e se reproduz a partir das instituições, mas como o mundo está e, portanto pode ser mudado, alterado e negociado.

\footnotetext{
${ }^{3}$ http://archive.co-op.ac.uk/holyoake.htm
}

Cooperativismo é muito mais "cooperativismos". Podemos encontrar o termo nos lugares mais variados e contraditórios, ora de maneira doutrinária, ora de maneira organizadora e, infelizmente, de maneira também corrupta (R. M., 2003). O mesmo acontece com a autogestão palavra que nasce na França para se referir à experiência na Iugoslávia após a Segunda Guerra Mundial, mas que tem ecos dos muitos acontecimentos e momentos libertários dos últimos dois séculos (Cedeno, 1999). O curioso, entretanto não são estes momentos - que são bem conhecidos na história coletiva operária (a Comuna de Paris, as Comissões de Fábrica em Torino, os Soviéticos nos primeiros dias da Revolução Russa, a organização da agricultura e da indústria pelas anarquistas na Catalunia durante a Guerra Civil) - o curioso é a maneira em que a psicologia social os transformou, via Le Bom, em exemplos da histeria das massas (Ginneken, 1992). Se você tem dúvida, basta olhar os livros de texto para ver que, em geral, a psicologia de grupos de mais de sete a dez pessoas se reduz à discussão sobre o que acontece quando o individuo perde sua autonomia e assume a personalidade selvagem da multidão, agindo fora de si. Nada sobre a capacidade de grupos grandes de se autogestionar, de criar mecanismos horizontais de consulta e de debate, de operar sem o Estado.

Solidariedade se refere ao ato de juntar-se aos outros de maneira "sólida". Quer dizer, lado ao lado, dividindo as mesmas responsabilidades e consequências. É uma referência a uma relação horizontal e não vertical; ou melhor, de horizontalização enquanto processo social. Não é, portanto, uma relação de ajuda ou de caridade; ao contrário, é uma relação de ação, de compartilhamento. Bem, sobre a solidariedade podemos ser um pouco mais otimista - afinal aqui temos algo que pelo menos aparece em um dos livros de texto que usamos na América Latina, a de Ignacio Martín-Baró (1983) que discute a solidariedade junto com a ação pró-social. Entretanto, de novo podemos perguntar quantas pessoas que utilizam o termo, se posicionam no sentido de ser efetivamente solidário, lado ao lado e de maneira indissociável.

Por que será que encontramos tão pouco na psicologia e na psicologia social a respeito destas palavras que parecem ser chaves para a compreensão de processos de mudança. Colocado de maneira simples, são conceitos que assumem como ponto de partida a interação, a 
intersubjetividade e a coletividade. Não são ideias que podem ser reduzidas ao nível individual e, consequentemente, não são ideias que podem ser construídas a partir do individual. Pertencem ao terreno de meio alcance da ação comunicativa (Habermas, 1989), da produção coletiva de sentidos, das materialidades e das socialidades. Pertencem a uma psicologia social não reducionista e distinta da psicologia.

\section{Uma psicologia social independente já existe}

Esta psicologia social autônoma e independente já me parece existe; o que é necessário é reconhecê-la. Existe em teses e dissertações produzidas em volta da temática de relações econômicas alternativas onde, de maneira tentativa, novas ideias estão sendo apresentadas para debate. Existe nas experiências comunitárias, onde pessoas estão reconhecendo que a atuação da psicologia social precisa ir muito além da formação de grupos de discussão e se engajar com os processos de luta para a melhoria e a dignidade. Existe no respeito para com as formas organizativas existentes e na capacidade de reconhecer a sua centralidade enquanto recursos de mobilização e ação. Existe no reconhecimento que os processos de ação social andam passo a passo porque não há um caminho pré-estabelecido, capaz de ser pré-planejado. Ao contrário, é um processo que busca compreender as possibilidades, identificar os bloqueios e discutir as alternativas.

Haverá muito a ser aprendido sobre poder enquanto ação, sobre como confrontar e pressionar, porque o terreno de médio alcance é onde as necessidades se transformam em interesses. Haverá muito a ser aprendido também sobre tempo, porque processos de mobilização e mudança raramente se encaixam dentro do semestre escolar. Uma psicologia social independente exigirá a recuperação de outros tipos de relação entre a universidade e a sociedade, entre as diversas comunidades de saberes; outros mecanismos democráticos e compartilhados de análise e de uma outra relação com o campo.

Eu sugiro que já demos à psicologia tempo suficiente de romper com suas raízes, e vimos que não é capaz de abrir mão de sua ontologia liberal e individual. Precisamos de uma psicologia social capaz de respeitar as capacidades coletivas expressas em saberes, práticas e ações organizativas, com a disposição e a competência de entrar na luta para as utopias, capaz de compreender as redes solidárias, a autogestão e a solidariedade... Talvez está na hora de acharmos o nosso próprio caminho.

\section{Referências}

Adorno, T. (1967). Sociology and Psychology. New Left Review, 46, 6780.

Alinksy, S. D. (1965). The war on poverty - political pornography. The Journal of Social Issues, 21, 1,41-47.

Cedeno, A. A. L. (1999). Guia múltiplo de ato gestão. Dissertação de Mestrado. PUC-SP.

FASE - Federação de Órgãos para Assistência Social e Educacional (2003). Estudo sobre indicadores de desenvolvimento humano no projeto Brasil 2000 - novos marcos para as relações raciais. Rio de Janeiro.

Freire, P. (2001). Ação cultural para a liberdade. São Paulo: Paz e Terra.

Ginneken, J. van. (1992). Crowds, Psychology and Politics, 1871-1899. Cambridge: Cambridge University Press.

Habermas, J. (1998). The inclusion of the other: studies in political theory. Cambridge, Mass: MIT Press.

Habermas, J. (1989). Consciência moral e agir comunicativo. Rio de Janeiro: Tempo Brasileiro.

Horwitt, S. D. (1989). Let them call me rebel: Saul Alinsky — his life and legacy. New York: Alfred Knopf.

Kukathas, C. \& Pettit, P. (1995). Uma teoria da justiça e os seus críticos. Lisboa: Gradiva.

Law, J. \& Mol. A. (1995). Notes on materiality and sociality. The Sociological Review, 43, 2, 274-294.

MacIntyre, A. (1984). After virtue. Indiana: University of Notre Dame Press. 
Martím-Baró, I. (1983). Acción e ideologia. Psicologia Social desde Centroamérica. San Salvador: UCA Editores.

Programa Gestão Pública e Cidadania na FGV-EAESP. Disponível em: $<$ http//inovando.fgvsp.br>.

Rawls, J. (1997). Uma teoria da justiça. São Paulo: Martins Fontes.

Sandel, M. J. (1998). Liberalism and the limits of justice. Cambridge: Cambridge University Press.

Skinner, Q. (1998). Liberty before liberalism. Cambridge: Cambridge University Press.

\section{Um outro olhar sobre a inclusão social e o trabalho do educador}

Paulo Peixoto de Albuquerque

É uma satisfação participar deste encontro e compartilhar com vocês algumas reflexões sobre o processo de trabalho do educador e sobre a inclusão social a partir da perspectiva sociológica.

Pensar a inclusão social, o trabalho e a educação, nos remete a ter presente o modo como os indivíduos, grupos e/ou organizações dão conta das situações problemas (o presente) e das decisões (escolhas a serem feitas aqui e agora), visto que o futuro é uma escolha intencional.

Para tanto vou apresentar o modo como percebo a questão da inclusão social.

Para mim, os processos de inclusão social precisam ser entendidos como um processo descontínuo fundado na pluralidade de práticas sociais datadas e localizadas historicamente (no Rio Grande do Sul temos o exemplo dos alemães, italianos e as experiências derivadas de diferentes grupos étnicos) que ao propor a autonomia do "nós", qualificou um tipo de relação social - a cooperação entre pessoas - porque o sentido destas práticas sociais tinha por base a reciprocidade, a confiança e o respeito ao outro.

Assim sendo, entendo inclusão social como um conjunto de ações intencionais de indivíduo e/ou grupo no sentido de superar uma situação problema/difícil e ao fazê-lo esta ação ganha um novo significado.

Dito isto, percebe-se que pensar ou discutir a inclusão social tem um atrativo porque até mesmo o maior egoísta tem um interesse em cooperar.

O egoísta coopera por três razões:

a) as normas de convivência entre as pessoas por serem fundadas na moral sinalizam que é bom que os outros percebam que estou aqui e sou solidário;

b) os indivíduos não são objetos, ao contrário, por serem capazes de construir-se como pessoa tem uma dinamicidade da qual não posso deixar de estar relacionado; e, 
c) principalmente, porque o outro é capaz de decisões que podem em última instância afetar meu modo de ser.

Estou trazendo à reflexão este exemplo para sinalizar que a questão do direito à inclusão implica e é uma "regra de ouro' que se apresentam em muitas culturas; a mais conhecida destas é aquela que diz: "não faça ao outro o que não quer que se faça a você" (novo testamento, Confúcio, literatura indiana, Islan, Gregos, etc.) entretanto é preciso resignificar o sentido proposto na regra de ouro, porque: "ama ao outro como a ti mesmo" é diferente de "ama a outra pessoa porque ela é como você".

Por isso que o título da minha fala precisa, nestes primeiros instantes, ser recolocado: não se trata de um novo olhar sobre direitos humanos e sim, um outro olhar sobre os processos de inclusão social, visto que as questões implicam em concepções de desenvolvimento e estes remetem aos direitos humanos.

Dito isso, abro minha reflexão apresentando os pressupostos do meu itinerário epistemológico (ou porque penso o que estou pensando, quando digo que se faz necessário um outro olhar sobre a inclusão social e o trabalho do educador).

\section{Paradoxo: "as coisas são do jeito que são e não são o que são"}

A fragilidade dos processos de educação é o seu aspecto paradoxal, porque a educação é um espaço de interpelação e convivência, mas é também e/ou ao mesmo tempo, instrumentalizante, pois permite que individualmente parceiros muito diferentes relacionem-se apenas por um interesse imediato (o cego e o paralítico podem se ajudar). Todavia, ao fazê-lo, este ato cujo interesse é imediato, tem como resultante uma ação coletiva que se diferencia na medida em que acaba por afetar a trajetória dos indivíduos que dela participam.

Modifica a intenção primeira, porque implica necessariamente em uma proposta de ação fundada na reciprocidade, na confiança e... na incerteza; por isso mesmo, necessita ser continuamente afirmada e nesta afirmação o consenso se apresenta não como verdade, mas como perspectiva, porque propõe e não tem por objetivo apenas momentos de emancipação dos interessados, mas a autonomia do coletivo.
Nesse sentido, pensar o trabalho de educação orientado para a inclusão social se apresenta como possibilidade diferenciada de organizar a vida, o trabalho e a produção. A educação enquanto processo intencional de ação coletiva emerge como contraponto necessário para fazer frente à pobreza, a marginalização e ao isolamento dos indivíduos na medida em que se habilita a resignificar os espaços de poder existentes na sociedade.

O paradoxo está no fato da educação ser pensada como uma saída coletiva fundada na responsabilidade privada - na intenção do indivíduo - ou seja, é a partir de interesses egoístas que eu pretendo colaborar com o outro, tendo por base fundamentos morais.

Esta perspectiva é o que torna equivalente uma proposta pedagógica com finalidades inclusivas e de resgate da dignidade com ação de cooperação ou filantropia: é bom ajudar aos outros.

Perspectiva muito diferente de Educação como construção coletiva de solidariedade(s), na qual o grupo é regido por mútua concordância de todos pelo seguimento de usos e costumes não imobilizados por leis, rotinas ou superstições, mas por um contínuo desenvolvimento para satisfazer as exigências sempre crescentes da vida livre (esta é a versão pensada por alguns teóricos da ação coletiva e de propostas pedagógicas voltadas para a autonomia como Joseph Proudhon, Sebastien Faure, Malatesta, Kroptkin, Bakunin e outros).

Solidariedade aqui é o diferencial proposto e tem a ver com solidariedade fundada em uma economia de trabalho, em identidade valorativa de grupo que é muito diferente de responsabilidade social fundada na filantropia e na responsabilidade individual.

É por isso que uma outra perspectiva de educação e Inclusão social como Direitos Humanos implica em pensá-la como a possibilidade de emancipações provisórias no sentido da autonomia, como o espaço plural e não instrumental de construção da justiça social.

O paradoxo dos processos de educação ou a ambiguidade do trabalho do educador não deriva da simples visão de coisas contraditórias, mas do choque da confrontação/posição de uma realidade percebida a níveis lógicos distintos, pois a liberdade de querer é o eixo da vida humana que não pode ser colonizada por uma razão utilitarista e instrumentalizante. 
Para nós, esta oposição coloca e expressa uma diferença que não pode ser pensada somente em termos de contradição, mas como um tipo de raciocínio que aponta fronteiras lógicas que hierarquiza e pontua a realidade.

Queremos dizer com isso que o paradoxo não se constitui num muro epistemológico intransponível, mas uma outra maneira de ver as coisas, de perceber o processo da cooperação que expressa também o paradoxo de uma cultura: o individualismo impede projetos coletivos, como ter o conhecimento como expressão da cultura de um grupo.

\section{Complexidade}

A sociedade moderna se afirmou a partir de pressupostos voluntariosos: liberdade, igualdade e fraternidade, mas nela fica evidente que o privilegiado nas relações sociais é o indivíduo. Indivíduo que, na maior parte das narrativas, só tem razão de ser na medida em que é protagonista, coordenador ou líder; protagonismo que se legitima na competição: é preciso sempre ser o melhor.

Mas ser o melhor implica em que outros sejam de menos, implica em conflito.

Este conflito em nossa sociedade se visualiza melhor quando se tem presente o mundo do trabalho e como se objetiva nele o conflito de interesses coletivo $\mathrm{X}$ indivíduo.

Segundo a lógica dominante este conflito pode ser neutralizado quando as energias dos indivíduos ou grupos são canalizadas para o mercado (ideal) ou para a busca de liberdade (entendida aqui na perspectiva de N. Bobbio de "liberdade negativa", porque narcisa e burguesa).

Para tanto, se faz necessário entender o mercado como lugar único e possível de se construir a vida. O grande problema é que pensar o mercado como único lugar possível de se construir a vida não se sustenta, principalmente porque a sua lógica tem por efeito a injustiça social e a violência.

É por isso que a vida precisa ser pensada a partir de outros lugares, de outras lógicas associativas.
Hoje a internacionalização/globalização financeira rompe os espaços nacionais e comunitários, as identidades coletivas derivadas do trabalho e acentua o processo de perda de identidade e marginalização e, isto ocorre, em função da incapacidade de crescimento do econômico ser possível para todos, daí o renascimento da experiência da cooperação e da solidariedade e... necessariamente, a questão da inclusão como um dos direitos humanos.

A discussão sobre Direitos Humanos deixa de ser um espaço privilegiado e de poucos - Direito a ter direito (Marshal) - e começa a ser construído através de iniciativas locais, ações baseadas na autogestão e nas necessidades do grupo, não nas necessidades do mercado.

Isto significa dizer que se evidencia uma outra ordem de direitos na medida em que os Direitos humanos se apresenta como sendo uma instância normativa e um espaço plural, ao mesmo tempo, com um sentido diferenciado: propor a partir de suas ações justiça social e um outro tipo de sociabilidade, diferente das trocas e da cooperação proposta pelo mercado.

A proposta de Inclusão Social é definida e proposta pela lógica do mercado, por isso mesmo precisam ser explicitadas, visto que os chamados "marginais" têm um papel e estão de certo modo "incluídos" nas políticas de voluntariado e serviços

Educar para a Inclusão Social enquanto intencionalidade precisa estar fundada na autogestão e só terá sentido quando marcadas por um conjunto de práticas que concorram não só para a emancipação dos grupos, mas para sua autonomia através de uma proposta pedagógica plural fundada na reciprocidade, na apropriação dos espaços públicos e no pensar o bem comum

\section{Não linearidade}

Terceiro elemento: a não linearidade como pressuposto. Não parece tão evidente, mas este pode ser identificado quando a gente tem presente a forma ou o processo de construção dos direitos no nosso país.

Convém salientar que a repertorização e a volta no tempo é muito mais que um artifício metodológico, pois traduz um movimento de resignificação do presente. 
Os fundamentos de uma sociedade solidária baseada no trabalho coletivo onde o bem-estar individual e da comunidade está acima do interesse econômico da produção não é resultado do acaso.

No Brasil este tipo de ação nunca ocorreu porque o processo de trabalho e a sua normatização sempre estiveram atrelados e tutelados, traduz-se, em um movimento de origem estatal, vinculados a uma política de governos que pode ser visualizada em três momentos.

\section{Primeiro momento: As bases-princípio do século $X X$}

Não se pode descolar a emergência dos direitos do e ao trabalho resulta das pressões da economia internacional, aliados aos processos de organização dos Estados-Nação na América, instaurando uma forma de atuar do Estado em que a questão social das áreas urbanas passam a ser elemento tangencial e secundário nas propostas e projetos de desenvolvimento.

Este cenário concorre para que no Brasil se desenhe uma configuração social fragmentada e imensamente diversificada, seja pela emergência de grupos demandantes de múltiplos interesses e de múltiplas identidades, seja pela diferenciação que se apresenta nas novas formas de organização do processo produtivo (pequena propriedade), no agir político e no comportamento da sociedade civil isolada e não participativa, porque estrangeira e/ou minoritária.

Evidentemente, que nestas primeiras três décadas do século XX os imigrantes tiveram um papel de destaque porque tiveram a capacidade de desenvolver suas próprias soluções para questões de fundo. Tal fato marca o sindicalismo de forma singular porque o associativismo se evidencia como alternativa concreta para evitar a dissociação crescente da vida cotidiana (universo instrumental da economia) dos valores e sentidos que pautavam o comportamento das pessoas (universo simbólico das culturas) e o vazio social e político das áreas/regiões de colonização.

Neste período o sindicalismo traduz ações estratégicas individuais e coletivas cuja meta não é criar uma outra ordem social, mas acelerar as mudanças, o movimento, a circulação de capitais, bens, serviços, informações.
O contexto de dissociação crescente dos valores dos grupos interioranos e o vazio social indicam que as dificuldades de constituição de sujeitos sociais foram a primeira realidade enfrentada no Brasil, principalmente porque no início do século 20 , no interior das áreas rurais, a questão do sujeito social (coletivo) só era entendida a partir do modelo institucional e representativo (que tinha nas associações políticas seu modelo mais significativo) e, por isso mesmo, as demandas eram elaboradas e delineadas institucionalmente de forma compartimentada a partir da divisão de temáticas que valorizavam as lutas na ótica da cidade.

Importante ressaltar que nos anos de emergência do sindicalismo, se caracterizaram na região sul principalmente pela existência de articulações plurais, nas quais os indivíduos buscam no coletivo construir estratégias de sobrevivência de um mundo estranho e em transformação.

Percebe-se que na afirmação dos princípios legais o "Sujeito Coletivo" construído pelos imigrantes adquiriu um sentido social mais amplo na medida em que transforma uma estratégia de sobrevivência em um movimento social de inclusão social; esse esforço por ser ator não deve ser confundido com um conjunto de experiências orientado por um princípio superior e sim, no desejo que todo indivíduo e/ou grupo social tem de resistir ao seu próprio desmembramento num universo em movimento, sem ordem ou equilíbrio.

Cada movimento de "inclusão", organizado seja pelos sindicalistas ou por outros grupos daquela época, deve ser entendido como um movimento de mudança, na medida em que o grupo tinha que inventar e diferenciar-se daquilo que já existia (carências e demandas não atendidas) para construir um outro futuro: o desenvolvimento daquilo que antes encontrava-se envolvido numa coexistência indiferenciada e de precariedade.

\section{Segundo momento: Anos da tutela e do controle 40/60/70/80}

Se de um lado, essa nova configuração do comportamento social consolida-se no Brasil, enraizando-se na ação social e no próprio processo social. Do surgimento dos sindicatos, cooperativas e grupos associativos variados percebe-se a complexificação do movimento de busca pela inclusão tão diversificada quanto complementar. Por outro lado, a nova 
configuração da economia marcada pelo cenário internacional de pósguerra concorre para uma política governamental de controle que desenha a partir do setor produtivo I (mais significativo economicamente) um sindicalismo e uma política associativa crescente, mas cada vez mais dependente das políticas do Estado.

Face às políticas do Governo Federal concedendo isenções tributárias e facilidades de crédito, há um crescimento significativo de um movimento sindicalista e cooperativista passivo que reage apenas aos estímulos de um modelo econômico determinado pelo Estado. É neste período que surgem os sindicatos pelegos (1964), ocorre o declínio do sindicalismo combativo. Neste período o sindicalismo e os espaços associativos deixam de ser um espaço plural e democrático para transformarem-se num instrumento das políticas governamentais e de apoio ao modelo econômico agroexportador.

\section{Terceiro momento: Reafirmação de um espaço plural anos 80/2000}

A nova configuração da economia marcada pelas transformações tecnológicas da informática e da microeletrônica concorre para que o contexto social deste período se caracterize por uma crescente e cada vez maior interdependência nas relações mundiais. Interdependência que, associada à valorização excessiva do liberalismo - configura, não só em nosso país, uma profunda crise social representada por índices crescentes de desemprego, miséria, desigualdades e exclusão social.

Nesse sentido, os anos 80/90 concorreram para um esforço de releitura do movimento sindicalista, cooperativista e dos direitos humanos, principalmente porque a realidade do associativismo se apresenta como uma combinação de movimento social e do sujeito aparentemente contraditórios e excludentes, mas que na verdade traduzem um processo social que articula atores diferenciados e introduz a noção mutação no agir associativo e no pensar os direitos humanos.

Não é a crise, mas as novas formas de organização econômica e da produção que estão dissolvendo os contornos da sociedade industrial. A mutabilidade das ações sociais se expressa e é sinalizada pela horizontabilidade das relações sociais, na formação de redes favorece ao modo diferenciado de pensar a economia a partir da cooperação.
No entanto, é preciso ter presente que, se até recentemente, o sindicalismo era o espaço que proporcionava a garantia dos direitos do indivíduo e uma forma de defender o trabalhador nos espaços produtivos, esta "resistência" designava apenas um estágio da modernidade e desenvolvimento, pois sua meta não era criar uma outra ordem social; a garantia dos direitos do trabalhador foi é vetor para a aceleração de mudanças no processo produtivo, mas não aparece como uma alternativa de pensar o econômico a partir de uma pluralidade.

Pluralidade necessária nas sociedades contemporâneas cujas bases se veem confrontadas com os limites do modelo proposto pela Sociedade industrial.

Modelo este que não têm capacidade ou condições internas para modificar suas políticas ou refletir sobre os efeitos perversos que modelaram o futuro que evidencia uma crise institucional profunda da própria sociedade industrial.

Nesse sentido, os Direitos humanos, como sistema, podem dar um salto qualitativo, porque a emergência de novas situações de trabalho (cooperativas educacionais, saúde, trabalho, turismo e lazer, infraestrutura, especial) de caráter essencialmente urbano, muito mais que uma estratégia de sobrevivência em uma sociedade de risco, apontam para a ruptura de uma política de continuidade e no pensar o econômico sob outras perspectivas.

$\mathrm{O}$ crescimento dos empreendimentos coletivos, articulados em rede dificilmente pode ser passível de compreensão sem a ideia de descoberta, de avanço das formas organizativas nas áreas urbanas que se dão de forma dispersa e longe dos processos de controle ou monitoramento promovidos pela CLT, é por isso que as causas do fenômeno associativo e cooperativo já não parecem encontrar-se na compreensão de uma legislação que está no passado, mas no futuro.

\section{Conclusão}

Nesse sentido, a educação ou práticas pedagógicas voltadas para o desenvolvimento, implica não só em pensar processos inclusivos, mas na determinação de Direitos humanos como sistema de forma a ir além da celebração de um contrato mútuo que estabelece obrigações visando 
objetivos comuns. A essência deste agenciamento da sociedade civil ao estar fundada em propostas educacionais que objetivem o estabelecimento de um outro tipo de agir coletivo pode possibilitar a implementação de um outro tipo de ação social.

O desafio está em construir uma proposta educacional que: negue a narrativa do mercado que esconde a existência de outras visões de mundo (porque aponta para a primazia do capital nas regulações societais) e recuse a lógica técnico-normativa que reduz o fazer humano na busca racional do interesse próprio.

O desafio esta na construção de uma política pedagógica ou de uma pedagogia política que não se deixe seduzir por discursos instrumentalizantes sobre direito a ter direitos, mas que possibilite pensar a construção de direitos humanos como um espaço social plural.

Parece-me que foi nesta perspectiva que se construiu este seminário e as discussões que até agora se fizeram.

\section{Referências}

Assmann, H. \& Mo Sung, J. (2003). Competência e sensibilidade solidária: educar para a esperança. Petrópolis: Vozes.

Bobbio, N. \& Mateucci, N. (1993). Dicionário de política. Conceitos de política, governos e sociedade civil. Brasília: Ed. UNB.

Freire, P. (2001). Medo e ousadia, (9 ${ }^{\mathrm{a}}$ ed.). São Paulo: Paz e Terra.

Kurz, R. (1992). O colapso da modernização: da derrocada do socialismo de caserna à crise da economia mundial, ( $2^{\mathrm{a}}$ ed.). São Paulo: Paz e Terra.

Luiz Filho, F. (1961). O cooperativismo no Brasil e sua evolução. São Paulo: Pongetti.

Schneider, J. (2003). A democracia, participação e autonomia cooperativa, ( $2^{\mathrm{a}}$ ed.). São Leopoldo: Ed. Unisinos.

\section{Redes solidárias, autogestão e solidariedade: o desafio da mudança social}

Maria da Graça Corrêa Jacques

Redes solidárias, autogestão, solidariedade são expressões que se incorporaram à linguagem cotidiana, com valoração positiva, mas com significados e interpretações diversas. Significados e interpretações que expressam modos diferentes de compreender o homem em sua inserção social e que fundamentam práticas variadas ancoradas em justificativas de controle social e de caráter moral.

É bom lembrar que muitas dessas justificativas foram arroladas quando da criação de asilos, hospícios, orfanatos, prisões e outras instituições totais, nas suas versões modernas, que se proliferaram no mundo ocidental nos últimos séculos. Hoje, as estatísticas mundiais sobre a pobreza, a desigualdade e a exclusão social (particularmente no caso brasileiro) são evocadas como argumentação para a implementação de práticas autodenominadas solidárias, envolvendo, inclusive psicólogos, como refere Spink em sua exposição.

A mesma argumentação tem sido usada como estratégia de marketing individual e/ou institucional. Redes solidárias, autogestão e solidariedade são expressões cuja materialidade confere ao seu portador um valor simbólico de reconhecimento social. São usadas, portanto, pelos diferentes segmentos muitas vezes como "mais um produto na vitrine" para consumo.

Daí se depreende a dificuldade e o desafio para os expositores dessa Mesa (e por certo para o papel de debatedora) em abordar a temática. Albuquerque em sua exposição se propõe a apresentar "um outro olhar" sobre os processos de inclusão social imbricado com as questões dos Direitos Humanos. Nessa perspectiva, o palestrante examina "o trabalho do educador orientado para a inclusão social e a educação como construção coletiva de solidariedade(s)" em oposição à perspectiva da educação como uma alternativa fundada na responsabilidade privada. Analisa e problematiza as propostas de inclusão social pautadas pela lógica do mercado, contrapondo com uma "proposta pedagógica plural fundada na reciprocidade, na apropriação dos espaços públicos e no pensar o bem com um". 
As reflexões de Arendt (1997) podem ser arroladas como sustentáculos para esse "outro olhar" ao conferir importância essencial ao espaço público na constituição da "condição humana", nas palavras da autora. Acrescenta:

Para o indivíduo, viver uma vida inteiramente privada significa acima de tudo, ser destituído de coisas essenciais à vida verdadeiramente humana: ser privado da realidade que advém do fato de ser visto e ouvido por outros, privado de uma relação "objetiva" com eles (...) o homem privado não se dá a conhecer e portanto, é como se não existisse. $\mathrm{O}$ que quer que faça permanece sem importância ou consequência para os outros e o que tem importância para ele é desprovido de interesse para os outros (p.68).

A mesma autora, ao eleger a ação como uma prerrogativa exclusiva do humano, preconiza sua dependência à presença constante de outros. Daí se depreende que a ação é composta de um começo desencadeado por alguém e de uma realização à qual muitos aderem para conduzir

(...) pelo fato de que se movimenta sempre entre e em relação a outros seres atuantes, o ator nunca é simples agente. Mas também e ao mesmo tempo, paciente (...) (p.203).

As proposições de Arendt ao discorrer sobre "a condição humana" sustentam uma outra ordem de "Direitos Humanos enquanto instância normativa e um espaço plural, ao mesmo tempo com um sentido diferenciado: propor a partir de suas ações justiça social e um outro tipo de solidariedade, diferente das trocas e das cooperações propostas pelo mercado", como defende Albuquerque em sua exposição.

A mesma crítica é formulada por Spink em sua apresentação ao assinalar que "redes solidárias, autogestão e solidariedade podem formar parte de uma frente libertária de pensamento transformadora, mas podem igualmente formar parte de uma frente liberal". Apoia-se na trajetória histórica e relembra a citação de Quentin Skinner (1998) de que "a liberdade vai perder terreno para o liberalismo e a discussão sobre autogoverno vai perder lugar para o Estado-Nação".

O expositor questiona a capacidade contributiva efetiva da psicologia e da psicologia social para a temática, quer na sua perspectiva ortodoxa, quer na sua perspectiva crítica. Vai além e pergunta se os saberes cotidianos, o senso da "solidariedade" e as boas intenções não são suficientes para fundamentar a proposição tanto de ações de redes solidárias como propostas de autogestão.

Tal asserção remete ao contexto em que a psicologia se apresentou como disciplina científica, no final do século XIX. É a partir da consolidação da categoria indivíduo, que se expressa, por exemplo, nas produções artísticas e literárias (como os retratos e as biografias) e no uso do pronome eu para se referir a si mesmo, que se abre espaço, na fragmentação das ciências humanas e sociais, para a introdução de um campo de conhecimento e de prática cujo objeto central é o indivíduo. Mesmo considerando que tal justificativa se torne um impeditivo à transformação que se processa nos campos disciplinares, é inegável a importância da exacerbação do individualismo como determinante na configuração do conhecimento científico.

Albuquerque em sua exposição apresenta a relação entre os interesses econômicos e os movimentos sociais pautados em ações solidárias e de autogestão. Examina, em especial, o movimento sindical e suas modificações no último século. Aponta que, as transformações do cenário mundial nas últimas décadas sustentam a proposição de práticas sociais visando a inclusão, a solidariedade e a autogestão e a criação de redes solidárias delineadas sobre a mesma lógica que pauta as relações sociais em que a centralidade do mercado se apresenta como parâmetro de avaliação.

Essas considerações remetem a uma reflexão contínua sobre esses movimentos. O parâmetro "desenvolvimentista" hegemônico adotado pelo mundo ocidental a partir do mercantilismo sustenta a proposição de políticas e práticas sociais consonantes com esse paradigma. Portanto, não basta boas intenções e reconhecimento social, pois expressões como redes solidárias, autogestão e solidariedade são empregadas para ações diversas pautadas em lógicas e parâmetros os mais diversos.

Spink na sua apresentação questiona a divisão e valoração diferenciada dos saberes que se expressa em "aulas sobre cidadania", "verdadeira autogestão" e "autêntico cooperativismo" como se essas respostas não fizessem parte da experiência cotidiana das comunidades envolvidas. Vai além e questiona o por quê que em nenhum momento 
alguém pergunta: "quando vocês querem fazer algo como vocês fazem? Como vocês se organizam por aqui?".

A questão que se coloca é o quanto as disciplinas científicas, entre elas a psicologia, podem efetivamente contribuir para sustentar teórica e metodologicamente a criação de redes solidárias e ações de autogestão e solidariedade. Explicitamente, Spink pergunta se a psicologia e a psicologia social em particular sustentam as inúmeras experiências positivas ora em curso e amplamente divulgadas em encontros científicos. Retoma, inclusive, para ilustrar, a maneira como a psicologia social compreendeu a Comuna de Paris, as Comissões de Fábrica em Torino, a Revolução Soviética "via Le Bon em exemplos de histeria de massas". Antes de centralizar a crítica tão somente na psicologia, a advertência de Codo (1985) de que não é privilégio da psicologia o compromisso com as classes dominantes, propõe a amplitude da questão. Acrescenta que a ciência como um todo ao produzir conhecimento que necessariamente implica poder, não escapa por algum exercício mágico de neutralidade, de ser apropriada pelas classes dominantes e utilizada em seu benefício.

O que os expositores apresentaram remetem a problematização contínua do que se tornou senso comum e intrinsecamente valorizado positivamente: redes solidárias, autogestão e solidariedade. Importante se faz examinar a lógica que fundamenta essas experiências. Portanto, não basta o engajamento em políticas e ações que, em nome da moral e da ordem social, proponham-se a alterar as estatísticas mundiais sobre desigualdade, exclusão social e pobreza, lembrando que essa mesma lógica pautou a exclusão de um grande número de pessoas, isolando-as em asilos, orfanatos, presídios e hospícios.

Encerro minha participação como debatedora dessa Mesa reforçando o ponto de vista dos expositores de que não basta compartilhar expressões "politicamente corretas", mas que necessário se faz construir através de redes solidárias, autogestão e solidariedade um outro saber e um outro fazer (emprestando a expressão de um dos apresentadores) sobre a temática. Para ensejar o debate, cito uma passagem de Giddens (1982) que aponta para a dialética da transformação social. Segundo o autor, a vida moderna empobrece a ação, mas favorece a apropriação de novas possibilidades; ela é alienante, mas ao mesmo tempo, de maneira característica, os homens reagem contra as circunstâncias sociais que consideram opressivas.

\section{Referências}

Arendt, H. (1997). A condição humana, ( $8^{\mathrm{a}}$ ed.). Rio de Janeiro: Forense Universitária.

Codo, W. (1985). O papel do psicólogo na organização industrial (notas sobre o 'lobo mau' em psicologia). In S. Lane \& W. Codo (Orgs.). Psicologia social, o homem em movimento, ( $3^{\mathrm{a}}$ ed.): (pp.195-202). São Paulo: Brasiliense.

Giddens, A. (1982). Class struturation and class consciousness. In A. Giddens \& D. Held (Orgs.). Classes, power and conflict (pp.157174). Berkeley: University of California Press.

Skinner, Q. (1998). Liberty before liberalism. Cambridge: Cambridge University Press. 


\section{SIMPÓSIO 3 - ESTRATÉGIAS DE RESISTÊNCIA E CRIAÇÃO}

\section{Estratégias de resistência e criação: ontem, hoje...}

Cecília $M^{a}$ B. Coimbra

Lembra daquele tempo que sentir era a forma mais sábia de saber e a gente nem sabia?

(Alice Ruiz)

\section{Introdução}

Serão aqui lembrados alguns movimentos de oposição à ditadura militar no Brasil, ocorridos nos anos 60 e 70 e os chamados hoje movimentos por uma outra globalização ou "movimento dos movimentos" (Cocco, 2002). Estes novos atores-resistentes vêm forjando movimentos múltiplos (formados por muitos movimentos), globalizados (formados por fluxos de mobilização internacional) e constituintes (o Fórum Social de Gênova, por exemplo, foi o embrião de novas mobilizações que vão emergindo em várias partes do mundo) (Cocco, op.cit., 13). Dentre esses vários, diferentes e múltiplos movimentos será trazido um deles: o zapatista - um pouco de sua história e funcionamento.

Sobre os movimentos ocorridos em nosso país nos anos 60 e $70-$ em que fui contemporânea ativa - e seus processos de subjetivação serão apresentados algumas de suas facetas, muito em função da minha experiência enquanto militante naquele período.

Trazer um tempo vivido intensa e ativamente, de forma uma tanto frenética, pois tudo nos parecia urgente de ser realizado, sem cair numa espécie de saudosismo conservador, é um desafio. Desafio que me proponho correr ao tentar trazer alguns fragmentos de uma história que nunca será somente minha, mas a de uma geração que generosamente sonhou, ousou, correu riscos e, como "a peste, foi marcada, massacrada e exterminada. (Uma geração) que, nos anos 60 e 70, apaixonadamente tentou marcar suas vidas não pela 'mesmice', pelo instituído, pela naturalização, mas ao contrário, pela denúncia, pela desmistificação, pela criação de novos espaços" (Coimbra, 1995).
Esta história compõe-se, portanto, de muitas outras histórias: dos que sobreviveram, dos que sucumbiram e - por que não? - dos que, muitas vezes, aterrorizados assistiam e/ou passavam ao largo dessas mesmas histórias.

Trazer esses tempos de militância - descritos aqui, inicialmente, como um tanto eufóricos e mesmo despreocupados, pois, sem dúvida, acreditávamos e pensávamos poder mudar o mundo e, posteriormente, como tempos sofridos e dolorosos, quando recrudesceu o massacre, o extermínio - é caminhar num fio de navalha, numa "corda bamba". Ao final, rapidamente será apresentado um movimento atual de resistência que aponta para a possibilidade de criar outros mundos: o movimento zapatista.

Contar essas histórias é, sem dúvida, uma tentativa de navegar por outras histórias, diferentes da oficial que nos tem sido apresentada e afirmada como única e verdadeira.

Sabemos que o processo de estruturação da memória coletiva tem se caracterizado como um dos campos mais sensíveis às disputas e aos confrontos de diferentes grupos sociais. A história que nos tem sido imposta seleciona e ordena os fatos segundo alguns critérios e interesses construindo, com isso, zonas de sombras, silêncios, esquecimentos, repressões e negações. A memória histórica "oficial" tem sido, portanto, um lado perverso de nossa história, produzida pelas práticas dos chamados "vencedores" no sentido de apagar os vestígios que os subalternizados e os opositores em geral vão deixando ao longo de suas experiências de resistência e luta. Essa história "oficial" tem construído desconhecimento sobre os embates ocorridos em nosso mundo globalizado, como se os opositores não estivessem presentes no cenário político; tentam apagar, até mesmo, seus projetos e utopias.

Entretanto, apesar desse poderio, essa história não tem conseguido ocultar e mesmo eliminar a produção cotidiana dessas outras histórias. Apesar das estratégias de silenciamento e acobertamento, essas outras histórias vazam, escapam e, de vez em quando, reaparecem, invadindo muitos de nós. 


\section{Os anos 60 e 70 no Brasil}

Toda uma geração de jovens estudantes e intelectuais viveu intensamente o alegre e descontraído início da década de $60,{ }^{1}$ continuação do que ficou conhecido como os famosos "anos dourados" - os anos 50 da Bossa Nova, do bem-humorado e sorridente presidente JK. ${ }^{2}$ Aqueles tempos caracterizaram-se pela implementação de projetos das chamadas reformas de base e de desenvolvimento nacional, frente ao reordenamento monopolista do capitalismo internacional, o que gerou uma política populista dos governos daquele período. ${ }^{3}$

Foi naquele quadro que se fortaleceram diferentes movimentos sociais que se voltaram para a "conscientização popular", Sem dúvida, aqueles anos estiveram marcados pelos debates em torno do "engajamento" e da "eficácia revolucionária", onde a tônica era a formação de uma "vanguarda" e seu trabalho de "conscientizar as massas" para que pudessem participar do "processo revolucionário". A efervescência política, o intenso clima de mobilização e os avanços na modernização, industrialização e urbanização que configuravam aquele período traziam, necessariamente, as preocupações com a participação popular. ${ }^{4}$

Ressoavam muito próximos de nós os ecos da vitoriosa Revolução Cubana, que passou a embalar toda uma juventude e grande parte da intelectualidade latino-americana, como o sonho que poderia se tornar realidade.

Foi a época do Centro Popular de Cultura da UNE, dos Cadernos do Povo Brasileiro, de filmes como Cinco Vezes Favela e do então inacabado Cabra Marcado para Morrer. A finalidade era "educar o povão" através da arte. No nordeste, Francisco Julião e as Ligas Camponesas incendiavam com sonhos de liberdade e de reforma agrária os pequenos camponeses da Zona da Mata. Diferentes experiências com alfabetização de adultos eram realizadas, desde "Com Pés Descalços Também se Aprende a Ler", no Rio

\footnotetext{
${ }^{1}$ Sobre o assunto consultar Coimbra (1995). Hollanda (1978). Maciel (1987). Schwartz (1978). Bueno (1987), Ventura (1988). Reis Filho (1988), dentre outros.

${ }^{2}$ Juscelino Kubischeck governou de 1956 a 1961.

${ }^{3}$ Jânio Quadros em 1961 e João Goulart de 1961 a 1964.

${ }^{4}$ Hollanda (op.cit.)
}

Grande do Norte, passando pelo Movimento de Cultura Popular, em Pernambuco até o Programa Nacional de Alfabetização de Paulo Freire, em Pernambuco e Rio de Janeiro.

Tratava-se, sem dúvida, da produção de territórios singulares, ainda marcados, muitos deles, pela sisudez, rigidez e stalinismo vigentes no período e que foram radicalizados pela geração de 68. Provavam-se e aprovavam-se novos valores e padrões de comportamento, especialmente entre a juventude e a intelectualidade militante. A participação das mulheres passava a ser gradativamente valorizada, não somente em sua profissionalização, mas principalmente no seu engajamento político, apesar de todos os limites que ainda eram impostos pelos companheiros de militância. O casamento deixava aos poucos de ser para nós a única perspectiva honrada de independência familiar. Explorávamos novos caminhos onde se tornava fundamental a satisfação pessoal nos mais diferentes relacionamentos, desde a sexualidade até o trabalho. Este deixava de ser uma mera ocupação, por vezes provisória, para tornar-se uma via legítima de realização pessoal e afirmação da própria independência.

Queríamos mudar o mundo, era a nossa questão básica; mais: tínhamos a certeza de que isso ia acontecer (...) Não nos passava pela cabeça que o ser humano pudesse passar seu tempo de vida sobre a terra, alheio aos problemas sociais e políticos; esta era para nós a pior das alienações. Foi assim que, nos anos 60, produziu-se uma arte política, uma cultura voltada para a questão social. Muitos da geração comprometeram suas vidas com a política e seu modo específico de encarar a realidade (Maciel, 1987, p.7).

O pacto populista entre o governo de João Goulart e os setores populares, além de se fragilizar, começava a se tornar perigoso para a expansão monopolista do capital estrangeiro. Naquele quadro deu-se o golpe militar de 64, quando as forças armadas ocuparam o Estado para servir a tais interesses. Para isso, e como preparação de terreno, uma intensa campanha se desenvolveu desde os anos 50, por meio da qual se construía a figura do comunista como o traidor da pátria. $\mathrm{O}$ fantasma do comunismo ameaçava e rondava as famílias brasileiras; era necessário esconjurá-lo, estar sempre alerta para que a pátria, a família e a propriedade continuassem territórios sagrados e intocáveis por tal peste. Não foi por acaso que o golpe de 31 de março de 1964 teve o apoio de significativas 
parcelas das classes médias que denunciavam a comunização da sociedade brasileira e exigiam um governo forte.

E, apesar do golpe e da intensa propaganda anticomunista, das prisões, das cassações, dos primeiros desaparecimentos - em especial, entre operários, marinheiros e camponeses havia ainda uma grande difusão de toda aquela "postura participante e conscientizadora", no período que foi do golpe até 1968 .

Ali, naquele ano, deu-se o grande amordaçamento: o golpe dentro do golpe, o Ato Institucional $\mathrm{n}^{\mathrm{o}}$ 5, de 13 de dezembro de 1968, que encerrou a década de 60 e inaugurou os terríveis e dolorosos anos 70.

A partir daí, o regime militar consolidou a sua forma mais brutal de atuação através de uma série de medidas como o fortalecimento do aparato repressivo, com base na Doutrina de Segurança Nacional. Dessa forma, estava garantido o desenvolvimento econômico com a crescente internacionalização da economia brasileira e a devida eliminação das "oposições internas". Silenciava-se e massacrava-se toda e qualquer pessoa e/ou movimento que ousasse levantar a voz: era o terrorismo de Estado instalando-se; a ditadura sem disfarces.

A censura tornava-se a cada dia mais feroz e violenta, dificultando e impedindo qualquer circulação e manifestação de caráter um pouco mais crítico.

A televisão passou a ter um nível de eficiência e eficácia internacional, fabricando e sedimentando valores e padrões para "um país que vai pra frente" (Hollanda, 1978, p.125).

Muitos passaram a acreditar no "Brasil Grande", no "progresso", no "crescimento", na "modernização", na "grande potência" que iria ser esse país. Ao lado disso, havia um profundo conformismo político, em que a defesa da ordem, da hierarquia, da disciplina, da submissão eram enfatizados, e onde o medo às autoridades dominava a todos, indo desde questões mais amplas até problemas os mais aparentemente triviais do cotidiano (Velho, 1987).

Duas categorias passaram a ser produzidas e muito disseminadas naqueles anos 70, no Brasil: a do subversivo ou terrorista e a do drogado, ligadas à juventude da época (Velho, 1987). A primeira era apresentada com conotações de grande periculosidade e violência, visto ser uma ameaça política à ordem vigente; deveria ser identificada, controlada e, se necessário, exterminada. Tal categoria vinha acompanhada de outros adjetivos, como: criminoso, ateu, traidor, etc., trazendo fortes implicações morais. O subversivo ou terrorista não estava somente contra o regime político, mas contra a religião, a família, a pátria, a moral, a civilização, tornando-se, assim, um antissocial. Estava contaminado por "ideologias exóticas", por mandatários de fora. No drogado, o aspecto de doença já estava dado, visto ser um ser moralmente nocivo, com hábitos e costumes desviantes. Na época, as drogas foram associadas a um plano externo para minar a juventude, tornando-a presa fácil das "ideologias subversivas". Aí, juntavam-se drogado e subversivo, o que se tornava perigosíssimo.

Ao lado dessas táticas repressivas mais sutis, os órgãos diretamente vinculados à repressão se sofisticavam dia a dia. Em 1964 foi criado o Serviço Nacional de Informação, crescendo a tal ponto que se transformou na quarta força armada não uniformizada (Stephan, 1986). De 1967 a 1970 foram estruturados os centros de informações do Exército (CIE), da Aeronáutica (CISA) e da Marinha (CENIMAR), assim como "forças unificadas antiguerrilhas" que receberam financiamentos públicos e privados: os DOI-CODIs (Destacamento de Operações e Informações/ Centro de Operações e Defesa Interna) que, em cada região militar do país, ficavam sob a jurisdição do Comando Regional do Exército. Tais eram seus poderes que uma certa análise política apontava para a existência de um verdadeiro Estado dentro do Estado.

Falar daqueles tempos é falar de uma viagem ao inferno: o dos suplícios físicos e psíquicos, dos sentimentos de desamparo, solidão, medo, pânico, abandono, desespero; é falar da "separação entre corpo e mente" (Pellegrino, 1988, p.19).

A tortura não quer "fazer" falar, ela pretende calar e é justamente essa a terrível situação: através da dor, da humilhação e da degradação tentam transformar-nos em coisa, em objeto. Resistir a isso é um enorme e gigantesco esforço para não perdermos a lucidez, para "não permitir que o torturador penetre (em nossa) alma, (em nosso) espírito, (em nossa) inteligência" (Chauí, 1987, p.34). 
Parece que foi ontem... Esta e muitas outras histórias continuam em nós marcadas a ferro e fogo... Fazem parte de nossas vidas... Falar delas é ainda duro... Parece realmente que foi ontem, hoje, agora... Envolvemonos, desde então, direta e/ou indiretamente com a luta contra a ditadura. Foi, sem dúvida, a experiência — não só a da tortura, mas a da militância naqueles anos - mais visceral de toda a nossa vida e que nos marcou para sempre. Nós que atuamos — na vanguarda ou na retaguarda, não importa - naquele intenso e terrível período, derrubamos muitos tabus, vivemos visceralmente a presença assustadora da morte, a ousadia de desafiar e enfrentar um Estado de terror, a coragem de sonhar e querer transformar esse sonho em realidade. Acreditávamos... Sim, queríamos um outro mundo, outras relações, outras possibilidades... e queremos hoje...

\section{O movimento zapatista}

Em setembro de 2002, estivemos no México. Interessava-nos acompanhar de perto, ainda que por poucos dias, o momento atual do movimento zapatista. O imenso interesse por este movimento sempre esteve presente em nós, muito em função de nossa militância e implicação com os direitos humanos.

Nossa curiosidade e interesse por esse movimento explicava-se também pela forte presença nele do pensamento múltiplo, da utilização de diferentes ferramentas, da capacidade de criação e invenção, da afirmação das potências.

Interessavam-nos, mais que tudo, outras formas de pensar o mundo, de fazer política...

O movimento zapatista surge oficialmente diante do mundo, em $1^{\circ}$ de janeiro de 1994, e se posiciona a partir da luta pela autonomia, direitos e cultura indígenas. A luta por esses direitos existe, pelo menos, há 500 anos, na história do México.

De 1983 a 1990, os focos guerrilheiros presentes na selva Lacandona (estado de Chiapas, ao sul do México), participantes da cultura emancipatória revolucionária — ativistas influenciados pelo foquismo de Guevara, pela permanência e avanços da revolução cubana, pela tomada do poder pelos sandinistas, na Nicarágua — encontram-se com a cultura de resistência indígena.

Não é nossa pretensão aqui conceituar o movimento zapatista, colocando-o dentro de definições e modelos já existentes, o que seria empobrecê-lo. As múltiplas lutas de resistência presentes na história mexicana atravessam, se atualizam e têm potencializado este movimento.

Os encontros entre grupos indígenas, camponeses, igreja progressista e organizações de esquerda produzem transformações teórico - políticas nas concepções marxistas - leninistas, trotkistas, maoístas e guevaristas, dentre outras — apontadas, muitas vezes, pelos indígenas e camponeses como "palavras ocas". Vai-se construindo, um processo de ação política onde a herança mexicana de luta pela terra também se faz presente, através das insígnias "democracia, terra e liberdade".

Vão se criando novas formas de construção e exercício da política e da ética, incluindo e afirmando as diferenças através da efetiva participação de todos. Tal participação não é mera questão de retórica neoliberal, mas volta-se para a afirmação das diferenças em sua radicalidade e singularidade, onde $\mathrm{o}$ direito a essas diferenças aponta para a multiplicidade, quando a riqueza da diversidade se faz presente.

Um desafio trazido pelo zapatismo tem sido a referência de que é possível fazer política sem a tomada do poder de Estado. Segundo o subcomandante Marcos, este é um desafio fundamental: “... Queremos inverter o exercício do poder (...) Nos dizem que isso é impossível, que não existe em teoria política (...) que não se pode fazer uma revolução política, sem a tomada do poder (...)" (Montalbán 2001, p.256). E continua: "A tomada do poder? Não, apenas algo mais difícil: um mundo novo" (Huerta, 1994, p.53). Esta nova forma de fazer política, de construir uma outra ética, caracteriza-se por uma prática que "não busca o acesso ao poder governamental, mas o controle deste através da organização social" (Paredes, 2002, p.134).

Uma outra concepção que inova em relação aos movimentos de esquerda, diz respeito à luta armada, que é percebida diferentemente do sentido clássico presente nas guerrilhas então conhecidas: a luta armada como um só caminho, como única verdade, em torno da qual tudo se aglutina. Afirmam que "o zapatismo é um movimento social que, ante a 
possibilidade da luta armada, opta também pelo diálogo e negociação..." (Revista Proceso, 2001, p.13). Se entendermos os movimentos de resistência como afirmação de algo e não negação ou reação a algo — uma re-existência - essa proposição de luta armada, pode ser pensada como um dentre outros recursos possíveis ou provisórios. Para Alain Badiou, a luta armada utilizada pelos zapatistas tem um caráter protetor do movimento. ${ }^{5} \mathrm{O}$ subcomandante Marcos a isto se refere, dizendo:

Nós não podemos entregar as armas em troca de uma promessa outra vez. Podemos calá-las, guardá-las e dar oportunidade para que esta promessa se cumpra. Não podemos entregar o único que temos: não temos terra, nem teto, nem educação, nem saúde. Simplesmente temos uma arma (...) (Huerta, 1994, p.77)

Dentro dessa concepção, é afirmada a crítica ao militarismo:

Nos tornamos soldados, para que um dia não sejam necessários soldados. Escolhemos esse caminho, (...) o de uma profissão cujo objetivo é desaparecer. Soldados que são soldados, para que um dia ninguém tenha que ser soldado. Foi por essa bandeira que nos tornamos soldados (Huerta, 1994, p.64).

Os militantes zapatistas usam o rosto coberto pelo que chamam de "pasamontafias", toucas de lã utilizadas, inicialmente, devido às baixas temperaturas da selva Lacandona. Essas toucas logo se tornaram um símbolo de luta, de coletivo, de não individualização, de força que está com todos e não apenas com alguns, de presença de muitos exércitos zapatistas, de muitos marcos, de muitos comitês revolucionários clandestinos. É como afirma o subcomandante Marcos: "Se querem saber que rosto há por trás da máscara, é muito simples: peguem um espelho e se olhem" (Huerta, 1994, pp.15, 16).

As visitas e trocas, como as nossas e as de tantos outros, têm produzindo muitos efeitos. Um deles diz respeito à organização de encontros, como o ocorrido, em 1996, "contra o neoliberalismo em escala

\footnotetext{
${ }^{5}$ Pronunciamento no evento "Resistências", em novembro de 2002, ocorrido no Rio de Janeiro, quando o conferencista assinalava o caráter heterogêneo de alguns movimentos de resistência.
}

intergaláctica e pela humanidade" ${ }^{, 6}$ anunciado em um mural que vimos no acampamento que visitamos. Nesse encontro, os zapatistas e seus aliados denunciaram o neoliberalismo como produtor de morte em escala planetária. Vão sendo tecidas, assim, as redes internacionais de solidariedade, de comunicação e encontro. Sobre o tema, os zapatistas dizem que têm

resistido em formar uma Internacional Zapatista (...) (pois) não queremos ser vanguarda. As coisas se produzem melhor se as pessoas que participam vão construindo seus próprios aportes históricos, não criando uma proposta esquemática contra o neoliberalismo e apresentando o zapatismo como um novo modelo mundial. Acreditamos nas redes de comunicação (...) Nossa riqueza está na diversidade da resistência e há que se estabelecer uma rede de resistências e propostas. Não há um centro que articule um só movimento de resistência mundial, mas uma rede que vibra quando uma resistência atua ou é agredida... A vantagem que temos é que não temos um centro, nem um plano pré-concebido que trate de homogeneizar as partes dessa rede (Montalbán, 2001, pp.172-173, 228).

Transcendendo às questões indígenas, até hoje não resolvidas pelos sucessivos governos mexicanos, o movimento zapatista incorpora, portanto, problematizações acerca da política, da ética, das chamadas minorias e da globalização. Em Chiapas, seguem os trabalhos de organização e administração das comunidades, de capacitação em educação e saúde e outros, nos acampamentos.

As regiões ocupadas neste estado chegam a $1 / 3$ de seu território, constituídas pelos chamados municípios autônomos ou comunidades zapatistas, onde não encontramos uma pobreza resignada, mas uma outra que aposta na resistência e na luta, evidenciando-se um grande apoio da população ao movimento. Em todo o México há grupos civis, ${ }^{7}$ intelectuais, parlamentares, movimentos sociais que compõem uma rede de apoio e

${ }^{6}$ O Encontro Intercontinental pela Humanidade e Contra o Neoliberalismo, conhecido popularmente como Encontro Intergaláctico, em agosto de 1996, quando participaram mais de 3.000 pessoas de 54 países do mundo.

A mais conhecida organização civil mexicana de apoio ao zapatismo é a Frente Zapatista de Liberação Nacional- FZLN. 
afirmação ao zapatismo. No mundo, comitês de apoio e solidariedade se multiplicam. O apoio político tem sido dado de diferentes formas, inclusive através de parte do envio de recursos financeiros, materiais e humanos para os acampamentos. ${ }^{8}$

Apesar de toda essa rede de apoio e solidariedade, há constantes tensões em Chiapas, tanto nas comunidades indígenas e camponesas, como nos acampamentos: invasões, prisões, presença ostensiva de militares, voos rasantes de helicópteros por toda a região e uma série de outras provocações. Além dos assassinatos e do terrorismo presentes, as autoridades utilizam uma série de outras estratégias para isolar e fragilizar o movimento. É como afirma José Saramago:

Fomos a Chiapas. Recolhemos impressões, conhecimentos, emoções.. Assim como outros que foram antes e os que irão no futuro, sabemos que temos a obrigação de contar o que vimos... Chiapas não é uma notícia em um jornal, nem uma dose cotidiana de horror. Chiapas é um lugar de dignidade... Devemos continuar viajando a Chiapas e falando de Chiapas... Quando se esteve em Chiapas, de lá não se sai jamais. Por isto, hoje estamos todos em Chiapas.

\section{Referências}

Bueno, A. L. L. (1987). Pássaro de fogo no terceiro mundo. Tese de Doutorado, UFRJ, Rio de Janeiro.

Chauí, M. (1987). A Tortura. Eloiza, B. (Org.). I Seminário do Grupo Tortura Nunca Mais. Petrópolis: Vozes. pp.28-37.

Cocco, G. \& Hopstein, G. (Org.). (2002). As multidões e o Império. Rio de Janeiro: DP\&A.

\footnotetext{
${ }^{8}$ Não foi por acaso que o apoio internacional esteve presente na grande Caravana Zapatista, ocorrida em março de 2001, quando, durante 15 dias, multidões acompanharam as lideranças zapatistas desarmadas, atravessando 12 estados, até a concentração final, no Zócalo - praça central - da cidade do México. Esta marcha ocorreu com o objetivo de pressionar o governo Fox quanto às reivindicadas mudanças constitucionais. Presentes, mais de 50 internacionalistas europeus, como José Saramago, Danielle Mitterand, Alain Touraine, dentre outros.
}

Coimbra, C. (1995). Guardiões da Ordem - uma viagem pelas práticas psi no Brasil do "milagre". Rio de Janeiro: Oficina do Autor.

Hollanda, H. B. (1978). Impressões de viagem. Tese de Doutorado, UFRJ, Rio de Janeiro.

Huerta, M.D (1994). Yo, Marcos. México: Ediciones del Milenio.

Maciel, L. C. (1987). Anos 60. Porto Alegre: L\&PM.

Montalbán, M.V. (2001). Marcos: El senõr de los espejos. México: Grupo Santilana de Ediciones.

Paredes, R. R. J. (2002). Nunca mais sin rostros. México: Ediciones y Gráficos Eón.

Pellegrino, H. (1988) “A tortura política”. A burrice do Demônio. Rio de Janeiro: Rocco. pp.19-21.

Reis Filho, D. A. (1988). 1968: a utopia de uma paixão. Rio de Janeiro: Espaço e Tempo.

Revista Proceso. (2001, 11 mar.). México, 1271.

Schwarz, R. (1978). Cultura e política, 1964-1969. O Pai de Família e Outros Estudos. Rio de Janeiro: Paz e Terra. pp.42-89.

Stephan, A. (1986). Os militares: da abertura à Nova República. Rio de Janeiro: Paz e Terra.

Velho, G. (1987). Individualismo e Cultura: notas para uma antropologia da sociedade contemporânea. Rio de Janeiro: Jorge Zahar.

Ventura, Z. (1988). 1968: o ano que não terminou. Rio de Janeiro: Nova Fronteira. 


\section{Competência ética e estratégias de resistência}

Virgínia Kastrup

Há tempos venho trabalhando sobre o tema da invenção, na interface entre as ciências cognitivas e os estudos da produção da subjetividade. Neste percurso, venho pensando a cognição como invenção de si e do mundo (Kastrup, 1999). A invenção não é um processo cognitivo especial, como a percepção, a memória, o pensamento ou a aprendizagem. É um modo de colocação do problema da cognição. Colocar o problema da cognição como invenção é conceber uma inventividade que permeia todos os processos cognitivos. Significa um giro na colocação do problema e mesmo uma outra política da cognição. A partir daí, falamos numa percepção inventiva, numa memória inventiva, num pensamento inventivo, numa aprendizagem inventiva.

A invenção é definida como a potência que a cognição tem de diferir de si mesma. Não é marcada por leis e princípios invariantes, mas por esta potência de diferenciação de si. Não se trata de explicar a invenção pelo inventor. O sujeito não é a fonte do processo de invenção, é seu produto, um dos seus produtos - o outro é o próprio mundo. Nesta medida, é preciso começar pelo meio, pelo processo, pela ação de conhecer e não pelas extremidades, polos ou inventos. O importante é pensar a potência autopoiética (Maturana e Varela, 1980) que a cognição possui, ou melhor, potência de coengendramento, recíproca e indissociável, de si e do mundo. A noção de coengendramento indica a presença de uma circularidade, de um mecanismo circular, marcada por um ponto de indeterminação no seu interior. Uma espécie de incógnita habita o interior do círculo criador da cognição. Isto significa que a cognição, que definimos com Humberto Maturana e Francisco Varela (1990) como ação autopoiética - e não como representação - conduz a resultados que não podemos prever de antemão. Pois não há fundamentos. Nem o sujeito nem o mundo podem ser tomados como fundamentos da prática cognitiva.

Vou retomar os pontos que destaquei até agora. A cognição não consiste na representação de um mundo pré-existente, mas é invenção de si e do mundo. Por outro lado, a invenção não está nas nossas mãos, pois falamos de um processo sem inventor, sem centro de controle. Por fim, não sabemos previamente quais os inventos ou produtos emergirão deste processo, o que pode parecer pouco animador quando pensamos em que estratégias de resistência podemos estar propondo para a invenção do nosso mundo e do nosso presente. Diante da ausência de fundamentos, me parece oportuno falar aqui sobre o conceito de competência ética de Francisco Varela (1995) e por este caminho abordar a questão das estratégias de resistência e de invenção do presente. $\mathrm{O}$ que pretendo colocar é que o traçado das estratégias de resistência requer uma discussão sobre a ética e política da invenção. Ética e política que são imprescindíveis para evitar que o conceito de invenção não esconda e traga consigo uma posição relativista, ou mesmo niilista, presente na fórmula: tudo se equivale, pois tudo não passa de invenção.

A obra de Francisco Varela no campo das ciências da cognição possui uma grande ressonância com a de Gilles Deleuze e Félix Guattari no campo dos estudos da produção da subjetividade. O ponto comum é a colocação do problema do sujeito e do objeto, do si e do mundo, do ponto de vista da produção. A subjetividade e a objetividade, o si e o mundo, não são entidades pré-existentes, mas são produzidos. Suas obras são elas mesmas, trabalhos de resistência em relação a posições hegemônicas nas suas respectivas áreas e neste sentido, elas devem ser tomadas como contribuições, ao mesmo tempo, teóricas e políticas. No caso de Varela, o que se encontra colocado é em primeiro lugar uma recusa ao ambientalismo, à posição que busca explicar o conhecimento como representação de um mundo dado e a ação como adaptação a este mundo. Se prestarmos atenção a esta ideia, não podemos deixar de pensar o quanto esta cruzada epistemológica, ou seja, o combate à noção de mundo dado, é indissociável da experiência do governo Allende e depois da ditadura no Chile, na época em que a teoria da autopoiese foi formulada.

No caso de Deleuze e Guattari, o que se encontra na linha de mira é a noção de sujeito, que traz consigo posições individualistas e familiaristas (Guattari e Rolnik, 1989). O que está em causa é sem dúvida uma posição micropolítica, onde as minorias são entendidas em seus modos de vida singulares, sem serem considerados inferiores ou mesmo patológicos. A perspectiva subjetivista é então recusada em favor da de produção da subjetividade. Subjetividade irremediavelmente coletiva, comportando vetores heterogêneos - políticos, sociais, econômicos, tecnológicos, etc. 
Articulando Varela, Deleuze e Guattari, pode-se afirmar que a noção de sujeito é substituída pela de um agente coletivo e processual, pelo que temos chamado de cognição coletiva. Somos todos agentes, fazemos parte do processo de invenção. Mas não há uma entidade substancial, um piloto ou centro de condução deste processo. Estamos num processo sem sujeito.

Como a posição ambientalista e a posição subjetivista são hegemônicas e ainda arraigadas em nós, é a elas que temos, em primeiro lugar, que resistir. Quando falo na recusa a essas posições toco na noção de resistência em sentido negativo - resistir a alguma coisa é não aderir a ela. Resistir é então suspender o que se apresenta como uma atitude natural, bem como a ação que se realiza em conformidade com ela. Já a resistência em sentido positivo é criação de uma outra atitude, de um outro ponto de vista, de uma outra política, de uma maneira de conhecer e de viver que prepara e é condição para a criação de novos mundos, a serem forjados caso a caso, através de estratégias concretas de ação. A resistência é então afirmativa, é vontade de outra coisa, bifurcação em relação às formas atuais do mundo e das subjetividades. É neste segundo sentido que o conceito de competência ética se apresenta como um conceito de resistência.

Varela (1995) afirma que a competência ética revela-se por uma ação imediata, que não é intermediada por regras e representações. É a partir do conceito de enação que diz respeito a uma cognição encarnada, configurada ao mesmo tempo que o contexto no qual ela se realiza (Varela, Thompson e Rosch, 1993), é que o conceito de competência ética é formulado. Nos quadros da teoria da enação, a competência é desenvolvida como um savoir-faire corporificado e contextualizado. O conhecimento relativo à maioria das atividades da vida cotidiana não recorre a uma unidade central ou a regras abstratas, mas é distribuído por todo o corpo. O problema da ética não equivale à discussão dos códigos morais nem à questão do juízo moral. A ação ética não exige mediação, não é intermediada por uma razão abstrata, mas é ação corporificada, inscrita corporalmente a partir da prática cognitiva em contextos específicos e domínios de interesses concretos e marcados por valências (Varela e Depraz, s.d).

Tal formulação é bastante distinta da posição sustentada, por exemplo, por autores como Jean Piaget. Piaget (1932) considera que o desenvolvimento moral ocorre de forma paralela ao desenvolvimento cognitivo. Este consiste em estágios sucessivos e sequenciais, cuja hierarquia é caracterizada pela passagem de uma posição egocêntrica, que atesta a incapacidade de se colocar no ponto de vista do outro, para uma posição de descentramento, onde as condições para o conhecimento objetivo são então alcançadas. No domínio cognitivo, o desenvolvimento consiste em passar da inteligência sensório-motora ao pensamento, da ação à representação, do concreto e contextual ao abstrato e universal. No domínio moral, não é a ação moral e sim o julgamento moral que se encontra no topo da hierarquia. Este é fundado numa competência intelectual e a questão é a construção de um ponto de vista objetivo e imparcial para o julgamento moral. Nesta mesma direção, L. Kohlberg (1981) apresenta o desenvolvimento moral como a construção progressiva de uma habilidade para afastar-se de uma situação e então poder agir e também justificar sua ação em termos de princípios morais universais. Como em Piaget, o sentimento de engajamento ou pertencimento à situação concreta que está em questão atesta uma posição ética inferior e que deve ser superada em favor de uma posição descentrada, abstrata e formalizada. Já a posição de Hubert Dreyfus (s.d) se aproxima da de Varela. As posições de Piaget e Kohlberg, bem como a de J. Habermas, que se baseia na última, são criticadas por Dreyfus justamente por seus dois pontos principais: a consideração de que o problema do julgamento moral prevalece sobre o da ação ética e o fato da aquisição da competência e da perícia ética ser marcada por um caminho que vai do concreto ao abstrato, do contextual ao formal.

A noção de competência ética de Francisco Varela indica que a conduta ética exige um processo de aprendizagem. Aprendizagem inventiva, pois ela não se confunde aqui nem com um processo de solução de problemas nem com a adaptação a um mundo pré-existente (Kastrup, 1998). Ela inclui a invenção de problemas, a experiência de problematização e é ao mesmo tempo invenção de si e do mundo. Varela (1995) assinala a necessidade de não limitar a cognição a um processo de solução de problemas. Através do conceito de perturbação ou breakdown é introduzida uma espécie de rachadura no sistema cognitivo, que assegura a continuidade de sua autopoiese. Em termos de funcionamento do sistema cognitivo, é justo ver aí um elemento de "disfuncionamento" que não é exceção, mas a fonte da cognição viva. Tal consideração atesta uma abertura do sistema cognitivo para a diferença, que aparece formulada na ideia de um mecanismo circular e criador, sem fundamento ou ponto de 
partida, portando em seu interior um ponto de interrogação e que caracteriza os sistemas cognitivos em geral, vivos e sociais (Varela e Dupuy, 1995). É por portar esta abertura para a diferença que a aprendizagem inventiva é resistência e não adaptação. Resistência tanto no sentido negativo - pois a problematização implica numa experiência de estranhamento e tensão em relação ao saber anterior, que responde pela atitude natural quanto no sentido positivo - já que ela cria outras formas de existir e outros mundos. A formulação, até certo ponto paradoxal, é que é preciso a mediação de um processo de aprendizagem para atingir a ação imediata que é própria da competência ética. A ação imediata que está em causa aqui não é espontânea, natural, mecânica ou automática, mas envolve a aquisição de uma perícia ou competência.

A tese formulada por Varela $(1995$, p.68) é que a competência ética é o progressivo conhecimento da virtualidade do si-mesmo. A tese indica que a aprendizagem envolve uma relação consigo mesmo. Ela reconhece também que a competência ética resulta de um conhecimento não do simesmo constituído, mas de um si-mesmo virtual, que é o conjunto dos processos que oferecem as condições de emergência do si-mesmo e que restam como condição de sua transformação. Tomando como base esses dois pontos - a ética como ação imediata e a importância do conhecimento da virtualidade do si mesmo — parece justo concluir que a competência ética baseia-se numa relação consigo que orienta ações concretas, configurando um modo de relação com as pessoas e com o mundo. $O$ que parece importante destacar é que a relação com as pessoas, ou seja, a relação social, envolve uma transversalidade da diferença, uma comunicação num plano de virtualidade que atravessa diferentes subjetividades.

A ética surge como disposição para acolher a diferença e responder àquilo que surge não como representação, como forma reconhecida, mas como breakdown, como problema. Ela implica uma disposição para agir de maneira imediata, que não parte de um eu centralizado nem está baseada no atendimento a regras ou códigos morais. A competência ética é adquirida em contextos específicos, não sendo baseada numa razão universal. Ela requer também a manutenção da capacidade de ser afetado pela diferença e de problematizar sempre o saber acumulado.

O que me parece importante sublinhar é que, do ponto de vista da cognição inventiva, a competência ética não pode assumir uma posição relativista, mas aponta para a invenção de um mundo ao mesmo tempo comum e heterogêneo. A hipótese que eu proponho é que é no nível da invenção de problemas, onde se dá uma experiência afetiva ou emocional no curso do processo de aprendizagem, que ocorre a possibilidade de transversalização de subjetividades e mundos constituídos, abrindo para a aprendizagem da competência ética (Kastrup, 2002b). É neste ponto que eu gostaria de propor o traçado de estratégias de resistência, ou seja, estratégias concebidas sob a égide do que chamei de transversalização da diferença.

O trabalho de uma oficina de leitura - Projeto Livração realizada com crianças de um meio social desfavorecido servirá para ilustrar em que consiste um processo desta natureza (Kastrup, 2002a; 2003). As crianças eram habitantes do bairro de São Domingos, na cidade de Niterói, e moravam em cortiços ocupados por inúmeras famílias através de invasões. No bairro os cortiços são considerados lugares perigosos, em função de sua precariedade assustadora, da violência, da ocorrência de tráfico de drogas e de outras atividades ilegais. Seus habitantes vivem numa espécie de comunidade separada. As crianças que lá habitavam, embora não cometessem delitos, sofriam diversos tipos de preconceito, em função da sobreposição da imagem da pobreza e a da violência. A vizinhança evitava o contato e a convivência com elas, que se expressava numa situação de apartheid social. Neste contexto, a realização da oficina de leitura baseou-se na ideia da criação de um espaço de heterogeneidade, de encontros improváveis, de aproximação e convivência com as diferenças, através da atividade de leitura conjunta. Realizada por estagiários e estudantes da UFRJ e da UFF, constituiu uma iniciativa dentro de uma política de inclusão social e de criação de um mundo comum e heterogêneo.

A roda de leitura, proporcionando a experiência com a literatura em grupos heterogêneos, foi a estratégia escolhida. A roda reunia crianças da comunidade, estagiários e amigos, num conjunto bem diferenciado quanto ao nível sociocultural, idade, escolaridade e experiência prévia com a literatura. $\mathrm{O}$ elemento que reunia o grupo era o texto literário, com sua potência de acionar experiências de problematização, afetos e emoções diversas, vividas através de uma prática coletiva e regular que produzia o curioso efeito de desmanchar identidades. O uso da arte justificou-se pela possibilidade que ela possui de acionar experiências afetivas e emocionais 
inéditas e pré-subjetivas, que não estão sob o controle de um eu central, mas são movimentos de saída de si. Tais experiências trazem à cena subjetiva uma dimensão de alteridade e indicam um plano e um caminho para a transversalização entre diferentes subjetividades. Ao reunir crianças e estagiários numa atividade conjunta, consistiu numa experiência de mão dupla e marcada pela reciprocidade. A proposta não foi estabelecer uma relação unilateral com as crianças, através do ensino de regras éticas de convivência ou mesmo da transmissão de um saber. O objetivo foi promover uma aprendizagem recíproca, incluindo todos os integrantes da roda num processo de aquisição da competência ética, que incluía a reinvenção de si e do mundo.

A ideia de que a aprendizagem da competência ética pode ser desenvolvida através de práticas de uma oficina de leitura implica na transversalização em dois sentidos. No primeiro, trata-se de passar do campo da arte ao campo da ética; no segundo, de passar do acolhimento da alteridade em si ao acolhimento do outro. A arte funcionou como um disparador de experiências da virtualidade do si-mesmo e dos modos já estabelecidos de enquadramento das situações e das pessoas. O objetivo foi propor práticas concretas capazes de desenvolver o que sugiro denominar uma disposição de transversalização, que é um estilo de enquadramento ético comprometido com a configuração de um mundo comum e heterogêneo. Trata-se de uma maneira de ver e de pensar que se apresenta como uma disposição de abertura e acolhimento da diferença. Ela orienta ações de invenção que ultrapassam um mundo pessoal, configurando um mundo em que as diferenças são incluídas, coexistentes e compartilhadas.

$\mathrm{O}$ encontro com a arte em situação grupal surge como o evento precipitador de um movimento de saída de si, que prepara a ação imediata em jogo na competência ética. Nesta medida, o modo de enquadramento das situações deve abandonar o egocentrismo. Mas o modo egocêntrico não dá lugar a um modo de enquadramento descentrado e abstrato, baseado na possibilidade de se colocar no lugar do outro, como defendem autores como Piaget e Kohlberg. Também não se trata de se destacar das situações e assumir um ponto de vista de ninguém ou de lugar nenhum, para usar a expressão crítica de T. Nagel (1986). O que está em questão parece ser antes desenvolver e cultivar um ponto de vista pluricêntrico. É disto que se trata quando Varela (1992) fala de rencantamento do concreto.
Tanto a relação com a arte como a relação com as pessoas são privilegiadas para a emergência de experiências de problematização, como são os afetos e emoções (Depraz, 1999). Afetos e emoções são geradores, cada qual a sua maneira, de movimentos de saída de si e de acesso ao si mesmo-virtual. No caso do trabalho com o grupo de crianças da oficina de leitura, a arte surgiu como um mediador das relações pessoais. Teve ainda o intuito de potencializar a experiência da alteridade em seus participantes, condição da transformação de subjetividades e expansão de domínios de interesses. $\mathrm{O}$ uso da arte visou, sobretudo, sua distinção em relação a um trabalho comunitário filantrópico, que é normalmente pautado na transmissão de valores e normas de conduta, considerados necessários à solução dos problemas da comunidade atendida.

Como um trabalho de longa duração, a oficina Livração funcionou como um dispositivo de aprendizagem inventiva para todos os participantes, crianças e estagiários. Aprender é, neste sentido, colocar em questão o que somos, pensamos e sabemos. É então um movimento de saída de si, um abandono de uma parte de si em proveito de algo que não é nem familiar nem garantido de antemão. A literatura foi usada para despertar e também cultivar um conhecimento do si-mesmo virtual, daquilo que nos habita como um campo pré-reflexivo de forças. A arte foi não apenas um evento precipitador, mas experimentada em situações de aprendizagem continuada, para cultivar um savoir faire com a virtualidade de si. Em resumo o uso da literatura com grupos heterogêneos e em Situação de aprendizagem continuada, em mão dupla, constituiu a singularidade desse empreendimento.

É preciso insistir que não se teve em mira uma competência ética objetiva e abstrata, mas ao contrário, singular e marcada por um campo de valências, construída de modo contextualizado e corporificado. Parece-me que a habitação de um território marcado pela heterogeneidade e a prática concreta do acolhimento das diferenças através do uso da literatura constitui um dos caminhos para a invenção de um mundo comum e heterogêneo. Nos termos em que colocamos inicialmente o problema, esse tipo de prática suscitou uma disposição de transversalização de subjetividades e domínios de interesse, resultante da relação continuada com a arte, com as pessoas, e com o si-mesmo virtual. Este campo habitado de modo marcante pela 
alteridade, onde a saída de si é constantemente experimentada, parece propício ao desenvolvimento de um ethos transversal.

Varela (1995) afirma que se aprende a competência ética como qualquer competência. Acrescentamos que ela não precisa ter uma aprendizagem específica, mas é passível de aquisição em diversas situações, dentre as quais a experiência com a arte se revela especial sua potência de problematização e mobilização da dimensão virtual do simesmo. Passando pela aprendizagem da virtualidade de si, cria uma disposição de transversalização que se estende à virtualidade dos outros e do próprio mundo. Transversalização capaz de passar do campo da arte ao da ética, do acolhimento da alteridade em si para o acolhimento do outro. Mas os efeitos não são garantidos nem totalmente previsíveis. Tal tipo de estratégia envolve uma aposta, certa dose de risco e certamente nossa própria disposição de nos transformar a partir das relações com o grupo, potencializadas pelo solo comum da experiência literária.

Sugiro que a aprendizagem inventiva tende para uma competência ética, que se desdobra no que chamamos de uma ética do saber implicado, que é, ao mesmo tempo, uma ética da saída de si. Tal ética, que implica na adoção de um ponto de vista pluricêntrico a partir do conhecimento do simesmo virtual, não deve ser confundida com uma posição relativista, que ronda as abordagens construtivistas. $\mathrm{O}$ que parece importante ressaltar é que o relativismo supõe um mesmo objeto encarado de diferentes pontos de vista. Neste sentido, não coloca em questão o mundo preexistente, enquanto o que parece importante para nós é a invenção de um mundo comum e heterogêneo. Esta ideia é também defendida por Bruno Latour (2002), para quem devemos começar por tomar a sério a diversidade dos mundos, recusando uma posição de simples tolerância. Afirma: "o mundo comum é para ser composto progressivamente, não está já constituído. Ele não está atrás de nós, já feito, como a natureza, mas diante de nós, como uma tarefa imensa, que temos que realizar pouco a pouco" (p.73). A meu ver, tal construção requer uma disposição de transversalização e ações concretas. Daí porque a noção de competência ética porta inevitavelmente um saudável tom político, que evita uma indesejável psicologização da ética. Do ponto de vista dos efeitos de invenção de mundo é bastante diferente ter uma competência e colocá-la em operação. Não basta a relação consigo mesmo e o conhecimento de sua virtualidade, mas sua explicitação por ações concretas e imediatas. Só assim podemos vir a inventar um mundo comum e heterogêneo. Pois a ação concreta não é uma escolha entre possíveis, mas ponta de presente, invenção, risco e aprendizagem permanente.

\section{Referências}

Depraz. N. (1999). Delimitation de l'émotion - Approche d'une phénoménologie du coeur. Alter 7.

Dreyfus, H. (s.d). What is moral maturity? http//socrates.berkeley. edu/ dreyfus (consultado em maio de 2001).

Guattari, F. \& Rolnik, S. (1989). Micropolítica - cartografias do desejo. Petrópolis: Vozes.

Kastrup; V. (1999). A invenção de si e do mundo. Campinas-São Paulo: Papirus.

Kastrup, V. (1998). A cognição contemporânea e a aprendizagem inventiva. Arquivos Brasileiros de Psicologia, 49, 4.

Kastrup, V. (2002a). Cartografias Literárias. Revista do Departamento de Psicologia da UFF, 14, 2.

Kastrup, V. (2002b). A propos de l'apprentissage de la compétence éthique. Intellectica, 35.

Kastrup, V. (2003). Production de subjectivité dans un atelier de lecture au Brésil. Chimères, 49.

Kohlberg, L. (1981). The philosophy of moral development. São Francisco: Harper \& Row.

Latour, B. (2002). Guerres des mondes - offres de paix. In Ethnopsy, 4, Propositions de paix. Colloque de Ceresy. Paris: Les Empêcheurs de Penser en Ronde/Le Seuil.

Maturana, H. \& Varela, F. (1980). Autopoiesis and cognition. Boston/ London/Dordrecht: D. Reidel Publishing.

Maturana, H. \& Varela, F. (1990). El arbol del conocimiento. Madrid: Debate. 
Nagel. T. (1986). The view of nowhere. Oxford: University Press.

Piaget, J. (1932). Le jugement moral chez l'enfant. Paris: PUF.

Varela, F. (1992). The reenchantment of the concret. In J. Crary \& S. Kwinter (Orgs). Zone - lncorporations. MIT. 6.

Varela, F. (1995). Sobre a competência ética. Lisboa: Edições 70.

Varela, F.,Thompson, E. \& Rosch, E. (1993). L'inscription corporalle de l'esprit. Paris: Seuil.

Varela, F. \& Depraz, N. (s.d). At the source of time: valence and constitutional dynamics of affect. Retirado em mar. 2002, http://www.liane.net/arobase.

Varela, F. \& Dupuy, J. P.(1995). Círculos viciosos criativos: para compreensão das origens. In P. Watzlawick \& P. Krieg (Dir.). $O$ olhar do observador. Campinas: Editorial Psi II.

\section{SIMPÓSIO 4 - CULTURA, INDIVIDUALISMO E SOCIABILIDADE CONTEMPORÂNEA}

\section{Os devires da cidade-pandemônio}

Carmen S. de Oliveira

\author{
Olho Brasília como olho Roma: Brasília \\ começou com uma simplificação final de \\ ruínas. A hera ainda não cresceu.
}

(Clarice Lispector, 1992)

São visíveis os indícios de que a sociabilidade contemporânea se pauta, predominantemente, pelo individualismo. De um lado, situações como o retraimento do social, os investimentos massivos na autoimagem, a evitação de vínculos mais intensos que têm levado alguns autores ao diagnóstico de uma crise na dimensão coletiva. Para outros, estamos diante de uma nova socialização flexível, que socializa dessocializando (Lipovetsky, s.d.), na medida em que o sujeito existiria para si próprio, isolado em um deserto societário. Nesta perspectiva, tampouco se consideraria isto como disfuncional, já que o isolamento e a indiferença ao mundo seriam condições ideais ao funcionamento do capitalismo contemporâneo, como veremos adiante.

De qualquer maneira, trata-se de um estranho paradoxo: quanto mais amplo o universo de referências em tempos de globalização, mais sozinhas as pessoas se encontram. Diante deste cenário, seria pertinente tanto indagar quais as ciladas deste tipo de sociabilidade, quanto curvar a questão em outro sentido para identificar possíveis forças de resistência que poderiam ativar as subjetividades para além da cultura narcísica. São indagações com explícita inspiração guattariana: se o buraco negro é o que captura, como sair dele? Como emitir do fundo de um buraco negro? (Deleuze e Parnet, 1998).

Creio que a esquizoanálise pode contribuir para esta problematização, muito embora este campo seja, por vezes, alvo de críticas por se acreditar que seu arcabouço conceitual faz a apologia de um modo 
de subjetivação desterritorializado e, sendo assim, se estaria reforçando os sintomas contemporâneos de dispersão e descompromisso. Tal julgamento lembra as restrições dirigidas ao lacanismo nos anos 60 e 70 no Brasil e em países vizinhos, quando se imaginava que o lamento acerca do declínio da função paterna e o insistente pedido de corte poderiam estar favorecendo o status quo da ditadura latino-americana. Curiosamente, as possíveis semelhanças quanto a controvérsias produzidas por ambos discursos não impede que, com alguma frequência, estes dois referenciais sejam colocados em oposição quanto ao entendimento sobre as estratégias de construção do laço social.

Todavia, como não se trata de "fazer do esquizo um herói dos tempos pós-modernos", conforme alertou Guattari (1992), caberia indagar algumas questões: em que medida se pode atribuir à falta ou flexibilização das referências o fato de que as pessoas tendem a estar atomizadas? Em tempos desterritorializantes, ficamos condenados ao narcisismo e à solidão? Será que estamos fadados a se deixar levar, assim como o vento sopra sobre a água vindo a dispersá-la e dissolvê-la em espuma e vapor?

\section{Quando os fios da trama se desprendem}

Como já referido, há quem diga que corremos o risco de nos afundar em particularismos, atrofiando os contratos sociais, em contraste com outros tempos e até mesmo outras culturas em que existiriam mais partilha comunitária, exatamente porque os homens cultuavam a memória e comungavam signos. Basta lembrar que o meio mais empregado pelos grandes governantes foi unir os homens em torno da celebração de grandes festas de sacrifícios e ritos sagrados, que expressavam tanto a articulação social como a ligação existente entre a família e o Estado. Envolvidos na música sacra ou no esplendor das cerimônias, as pessoas eram mobilizadas em suas intensidades, superando as divergências e dissolvendo particularidades.

O problema é que, ao longo dos tempos, tal modo de socialização mal e mal disfarçou um pressuposto quase religioso de conversão, através do submetimento aos deuses, da veneração aos antepassados, da fidelidade aos mestres e, de certa forma, a uma imagem de si mesmo. Insulados em territórios existenciais reiteramente investidos, os sujeitos se tornaram um tanto tagarelas, reproduzindo a sacrossanta palavra do Pai, bastante fiéis ao que vinha antes. Nada de bifurcações, ultrapassagens ou exposição, muitas vezes perigosa, ao outro.

Cabe ressaltar que não estamos, contudo, nos referindo a uma modalidade grupal pré-moderna e que, portanto, estaria em declínio. Este é um apelo ainda muito presente, em especial porque diante de uma realidade em dilaceramento, como na vida contemporânea, somos muito tentados a nos refugiar no ventre da mãe ou na sombra oferecida pelo manto paterno. Assustados, mas agarrados, nem suspeitamos de que nossos corpos vão sendo agenciados para evitar qualquer distensão, qualquer vibração. Ensimesmados, somos corpos que já não se lançam, retraídos e apertados, fruto de um longo treinamento para evitar os deslizes e sobressaltos.

A tudo isto, por um bom tempo, temos chamado de corpos bem educados para a vida pública. Dito em outros termos, como Serres (s/d) propõe, constituímos "corpos aristocratas", excessivamente destros para agarrar garfo, mão, caneta, raquete, cinzel, enxada, mas também arco e flecha, florete, martelo, foice, granada, AR-15...

Treinados para sermos destros, é razoável supor o tamanho de nosso susto quando os fios da trama se desprendem e as marcações se perdem. Isto se faz ainda mais presente em um contexto em que a velocidade, acirrada pelas demandas do mercado e pelas novas tecnolog1as, produzem a transitoriedade de bens, signos e valores, diminuindo as distâncias, mas também encurtando a memória. Enfraquecidos os laços, os sujeitos se sentem à deriva e, com isto, aumentam suas chances de se deixar capturar cada vez mais pelos apelos sedutores da cultura narcísica e da mídia.

Por outro lado, com as fronteiras em constante deslocamento, em tempos globalizados, afirma-se a soberania do indivíduo e a livre disposição de si próprio. Já não se tornam necessárias as adesões e fidelidades tradicionais, o que pode ser interessante para a inconstância e experimentação capitalistas, que podem se realizar com menos resistência. Da mesma forma, a indiferença é um grande aliado porquanto o indiferente não se apega a nada e está preparado para tudo, até mesmo para as mudanças inesperadas em suas próprias convicções (Lipovetsky, s/d).

Ganhar este desprendimento emocional torna-se, então, uma aspiração nos dias de hoje, a fim de que o sujeito se sinta abrigado das suas 
paixões e da dos outros, ainda que às custas da interdição dos sentimentos. Neste contexto de apatia frívola, a performance passa a ser mais importante do que o vínculo, reforçando a ideia de que quanto mais a cidade desenvolve as possibilidades de encontros, mais sós se sentem os indivíduos.

Sendo assim, poderíamos pensar que quando tudo converge para o declínio do espaço público estamos fadados ao individualismo? Será que a sensação de desamparo é tanta que torna difícil e até conflitante a prática da solidariedade social, como afirmou Freire Costa (1986) em seu clássico estudo sobre a cultura da violência no Brasil?

Há muitos elementos na paisagem atual e, em particular, no caso brasileiro, que nos sugere responder afirmativamente. Afinal, somos um tanto predisponentes às vivências históricas de desamparo diante de uma árida e injusta realidade, que aumentam as chances de subjugação à vontade do outro, ou da busca do "deve ser" ou de algum objeto perdido de representação. Ou seja, em um país onde os cenários desabam a cada instante e malogram as esperanças em torno de um sonho de emancipação cívica, é compreensível que sejam reforçadas as estratégias narcísicas de sobrevivência, como a lógica do "salve-se quem puder" (Oliveira, 2001) Assim, sobram evidências desta modalidade na paisagem brasileira: maracutaias, mamatas, lobby, jabás, favores de padrinhos e "painhos", etc Ou seja, o tripé clientelismo-corrupção-impunidade se tornou recorrente em quase todas as esferas da vida pública, dilapidando um genérico paubrasil em benefício de poucos e em detrimento da maioria.

Contudo, podemos também pensar que, quando um barco atravessa uma correnteza, todos a bordo precisam se unir, trabalhando coordenadamente. $\mathrm{O}$ risco seria aqui não um fator de desagregação do coletivo, mas um agenciamento que funcionaria como um objetivo superior aos interesses individuais. Senão, vejamos...

\section{O poder da auto-organização}

Esta é uma das hipóteses centrais de Steven Johnson (2003), considerado um dos grandes pensadores do ciberespaço, na abordagem do tema da interconectividade inteligente. Sua argumentação central consiste em demonstrar a existência de sistemas auto-organizados, nos quais se dispensa a presença de um controle centralizado para haver ação. Buscando demonstrar esta ideia ele analisa contribuições de pensadores, desde o terreno da biologia, da biofísica, do urbanismo ou do design de modernos softwares.

A princípio, seus argumentos sobre o poder da auto-organização produzem uma certa estranheza ao leitor, pois a maior parte do mundo à nossa volta ainda é explicada em termos de hierarquias e sistemas de comando. Afinal, estamos acostumados a nos organizar de cima para baixo, como no exemplo que o autor traz sobre os estudos do comportamento de um fungo.

No caso, o discoideum é um fungo, que passa grande parte de sua vida como milhares de outras criaturas unicelulares, movendo-se separadamente das companheiras. Porém, sob determinadas condições, as células vão se aglomerando em único organismo maior, particularmente quando o ambiente é mais hostil. Durante algum tempo, a crença geral entre os pesquisadores era de que as agregações se formavam pelo comando de células líderes, que ordenavam que as outras células se reunissem. A hipótese que vigorava era de que as conexões eram um gigantesco jogo de telefone sem fio, enquanto apenas algumas células de elite faziam a chamada inicial.

Entretanto, durante anos nenhum pesquisador conseguia encontrar os tais líderes, até que dois pesquisadores se fizeram perguntas mais radicais: e se não houvesse lideranças? E se as células se organizassem em comunidade por si próprias? Foram necessários quase vinte anos para que fosse demonstrado que as células daquele fungo se organizavam de baixo para cima, como sistemas bottom-up e não top-down, como denomina o autor. Em outras palavras, ficou comprovada a existência de complexos sistemas adaptativos em torno do comportamento emergente.

Todavia, é no exemplo da colônia de formigas que tudo isto pode ficar mais claro. Embora rainha seja uma palavra que lembra hierarquia, no formigueiro ela não é uma figura de autoridade, pois sequer decide o que cada operária faz, mesmo porque ela está no fundo do buraco e seria fisicamente impossível dirigir dali a decisão da colônia. Contudo, as formigas operárias mudam suas tarefas, da construção de ninhos à 
forragem, com uma coordenação social surpreendente, onde nenhuma formiga é encarregada da operação global.

Uma das grandes pesquisadoras, Deborah Gordon, entrevistada por Steven, refere que estava buscando investigar, através das formigas, sistemas em que os indivíduos não tivessem acesso à situação global, mas mesmo assim trabalhassem juntos de forma coordenada, fazendo uso apenas da informação local.

Alguns ideólogos de plantão diriam que este tipo de pressuposto vem de encontro às linhas de produção da sociedade industrial da primeira fase do capitalismo. Cabe, então, explicitar que o local aqui tem outro sentido, uma vez que os agentes individuais prestam atenção a seus vizinhos mais próximos antes de ficarem esperando por ordens superiores. Dito de outra maneira, eles pensam e agem localmente, muito embora sua ação produza comportamento global.

Estamos diante do poder do enxame: num coletivo de formigas, não há visões panorâmicas da colônia, mas elas vão se comunicando pela segregação de um certo número de substâncias químicas produzidas por suas glândulas — os feromônios. É uma comunicação tátil direta. Por isto, perceber as graduações deixadas pelos feromônios é essencial para saber qual a tarefa, onde tem comida, perigo, as rotas mais curtas etc. O feedback local pode se revelar como o segredo do planejamento descentralizado do mundo das formigas. Por outro lado, sua simplicidade de linguagem não é um defeito, mas uma característica útil.

Não se trata, portanto, de sistema de comando, mas de uma avaliação permanente das probabilidades. Como a tomada de decisão se dilui por milhares de formigas, a margem de erro é desprezível. Para cada formiga que, por acaso, superestima o número de cortadeiras, há uma outra que o subestima. $\mathrm{O}$ que temos são interações aleatórias, de explorações de determinados espaços sem qualquer ordem predefinida, mas se as formigas não topassem umas com as outras, as colônias seriam certamente um conjunto sem sentido de organismos individuais. Um enxame sem coletivo.

Ora, alguns dirão que, no caso dos seres humanos, o caráter aleatório seria menos decisivo, pois nossos genes poderiam ser considerados ditadores secretos, distribuindo planos fixos de crescimento para os soldados de nossas células. Mas esta possível tirania do DNA não contraria os princípios da emergência, pois se sabe que as células fazem mais do que seguir as regras, na medida em que, como no caso das formigas, elas também aprendem com as vizinhas.

O que atualmente os biólogos moleculares estão afirmando é de que as células coletivas que se empenham, por exemplo, para criar um tímpano vão emergindo por expressão genética, através de sinais transmitidos pelas suas junções. Isto é, as células se baseiam no código genético, muito embora necessitem de um "sentido de lugar" para cumprir sua tarefa, uma façanha conseguida pela estratégia de prestar atenção à vizinhança.

Diante dos resultados destas pesquisas trazidas por Steven, resta uma indagação: existiriam chances dos coletivos humanos construírem formas de organização social segundo um sistema elaborado de aprendizagem a partir do nível mais baixo, onde a inteligência coletiva e a adaptabilidade adviriam do conhecimento local?

\section{A cidade-pandemônio: uma criação coletiva}

Buscando responder a esta questão, o autor problematiza a cidade. Para ele, ninguém discordaria de que a cidade opera segundo uma ordem complexa, cujo movimento não é uníssono, mas uma intricada coreografia em que os bailarinos fazem solos e os conjuntos têm papéis específicos, que, milagrosamente, se reforçam e compõem uma unidade ordenada. Além disto, a arte desta dança não estaria dada a priori, como no caso dos ritos tradicionais, calcados em uma memória recapituladora, o que pode favorecer uma imagem um tanto caótica do espaço urbano.

Ainda que as metrópoles sejam demarcadas pelos altos edifícios, a magia da cidade viria de baixo, uma vez que as pessoas constituem consensos porque vão se encontrando, votando com os pés. Ela é uma máquina de aprendizado, que não é construída pelo "grande homem" que tem um lampejo de inspiração no laboratório, na biblioteca ou no seu gabinete enquanto burocrata ou político. Ao contrário, as teorias do "grande homem", da "grande ideia" ou até mesmo da "grande assembleia" ignoram os esforços dispersos, comunitários, de um mundo in process da cidadepandemônio, com seus demônios de nível inferior gritando para os de nível acima, que gritam para os de nível ainda mais alto e assim por diante. 
Nesta perspectiva, as calçadas seriam espaços privilegiados de interação, uma vez que a intimidade do uso da calçada traz uma sucessão de olhos. A ideia é de que os vizinhos aprendem uns com os outros porque passam uns pelos outros. O passeio poderia ser considerado ato, política, experimentação (Parnet. 1998). Como refere Steven, "as calçadas são as junções da vida da cidade" e desprovidas delas as cidades seriam como formigas sem o sentido do olfato ou uma colônia com um número reduzido de operárias.

Entretanto, cabe retomar aqui a metáfora da calçada para indicar a distinção importante entre o formigueiro e a urbe. As formigas seguem leis elementares e nós somos seres desejantes, capazes de guardar e recuperar informação e, principalmente, produzir novos sentidos. Ou seja, fazemos uso de um processo mais complexo do que simplesmente reconhecer. Para a esquizoanálise, "nunca se aprende fazendo como alguém, mas fazendo com alguém". Portanto, em se tratando dos coletivos humanos, não seria imprescindível a memória, nem o tempo. Para Deleuze (1987), “o essencial não é lembrar-se, mas aprender; porque a memória só vale como uma faculdade capaz de interpretar certos signos e o tempo só vale como matéria".

Sendo assim, as pistas deixadas pelos "feromônios humanos" ou, melhor dizendo, os signos mundanos, teriam a potência de nos mostrar, a todo o instante, a mudança que estamos vivendo, nos remetendo a cartografias do tempo que se perdeu e também do tempo que passa, alterando tudo e anulando o que passou. São signos que nos obrigam a pensar no tempo perdido, isto é, na passagem do tempo. Afinal, como refere aquele filósofo, "rever pessoas que nos foram muito familiares é uma revelação, porque seus rostos, não sendo mais habituais para nós, trazem em estado puro os signos e os efeitos do tempo, que modificou determinados traços, alongando-os, tornando outros flácidos ou vincados".

Como este processo tem pouco a ver com a rememoração, existiriam menos chance do sujeito se deixar enredar pelos modelos ou pelas ciladas dos espelhos. Por outro lado, na medida em que este traçado parte sempre em adjacência, "entre os dois" (que não está nem em um nem em outro, como a grama entre as pedras do calçamento), também diminuiriam os riscos de autorreferenciamento. Conforme propõe Deleuze e Parnet (1998), produzir um encontro é muito mais do que uma justaposição ou reunião. Nada de rebatimento, mas proliferação e multiplicações dos lados, quebrando o círculo da arborescência com seus eixos de rotação em torno do centro.

Nesta definição, as trilhas são sempre experimentações, onde sempre se está no meio do caminho, no meio de alguma coisa e, desta forma, o aprendizado não se daria pela memória recapituladora. Não existiriam tampouco autores ou sujeitos de enunciação com seus scripts narcísicos, pois o que se delineia já não é mais de ninguém: está “entre” todos. É uma interconectividade entre fluxos nômades que, no entanto, tem pouco a ver com dispersão, mas com sua capacidade de abalar o modelo, fazer brotar sua grama, até mesmo localmente, até mesmo nas margens. Isto nos permite afirmar que não, necessariamente, a falta ou flexibilização das referências tende a levar as pessoas à atomização.

Como lembra Steven, quando são poucos os cérebros explorando determinado problema, as células permanecem desconectadas, serpenteando na tela como células isoladas, cada uma seguindo seu curso aleatório. Nas linhas de feromônio que evaporam rapidamente, as células não deixam traço de seu progresso - como um ensaio publicado em um jornal, mas que fica durante anos na prateleira de uma biblioteca sem ser lido. Contudo, diria o autor, "conecte o maior número de mentes ao sistema e forneça uma trilha maior, mais durável e os pedaços isolados e obsessões particulares se aglutinarão em um novo modo de ver o mundo, compartilhado por muitos mais indivíduos". À maneira deleuziana, poderíamos acrescentar que a duração aqui se refere mais ao plano intensivo do que extensivo e que os territórios vão se configurando mediante consistência e não, necessariamente, organização.

\section{Brasília: uma cidade artificial?}

Neste olhar sobre a cidade interconectada e geradora de encontros, é inevitável evocar imagens contrastantes da arquitetura de Brasília, com suas grandes avenidas sem calçadas e esquinas, além das superquadras programadas para funções pré-definidas e que constituem possíveis obstáculos para a produção de interações aleatórias no espaço urbano. Neste sentido, Clarice Lispector (1992) escreveu sobre esta cidade nos anos 60, descrevendo-a como "uma construção com espaço calculado para as nuvens", "cidade traçada no ar", "perfil imóvel de uma coisa", "uma 
quadra de tênis", "um aeroporto", "cidade que fica fora da cidade", "uma prisão ao ar livre".

Em tal cenário, será que a privação das pessoas ao convívio da calçada as tornaria embrulhadas em um fino véu, tão mais esquálidas quanto mais alheias ao burburinho da vida, tão mais distantes quanto mais velozes trafegam nas largas avenidas ou nos corredores dos palácios, tão mais encapsuladas como a formiga rainha alheia às interações sutis que se produzem na colônia? Estaríamos diante de uma cidade-pandemônio às avessas, com seus demônios de nível inferior vampirizados pelos de nível acima, que são sugados pelos de nível mais alto e assim por diante? Um enxame sem coletivo?

Para aquela escritora, a construção da capital brasileira foi mesmo inspirada em um Estado totalitário e, por isto, ali seria "um lugar onde os crimes gélidos têm espaço" e "a alma não faz sombra no chão". A par das influências em um projeto modernista, que foi credo de várias gerações de urbanistas, é óbvio que o centralismo do poder na capital brasileira, com seu perverso sistema top-down, não se deve apenas a questões arquitetônicas. Se é verdade que em Brasília "os pés não tocam na terra", "não existe cotidiano", "falta magia" e "os olhos dos habitantes são secos demais para chorar", pode-se dizer que isto não é propriamente uma prerrogativa desta cidade.

Se o que estamos debatendo é justamente as armadilhas narcísicas, talvez fosse prudente lembrar que, mesmo quando existem calçadas para circular livremente, andamos muito em volta de nossos quarteirões e caminhamos pouco em ruas transversais. Quando muito, visualizamos algumas calçadas paralelas àquelas em que nos encontramos. Às vezes, até somos bem esforçados e vamos muito longe, alargando os passos e as trilhas, mas produzimos poucos encontros, raramente multiplicamos. Andamos muito, ora buscando o olhar dos outros, ora voltados sobre nós mesmos, forçadamente narcísicos, onde o complemento é visto apenas como sombra, tornando-se referência morta, privada de uma ligação virtual ao outro sentido. Em tais circunstâncias, nossos caminhos se tornam linhas que não fazem amor entre si e engendram um "coito falhado", na expressão de Serres (s.d.), o que demonstra que a filiação nem sempre é um antídoto suficiente para estes tempos de um nomadismo generalizado, que nos deixa sempre no mesmo lugar.
Talvez seja um pouco isto que Clarice Lispector queria dizer quando referiu ser urgente povoar Brasília: "Se não for povoada, ou melhor, superpovoada, será tarde demais — não haverá lugar para pessoas. Elas se sentirão tacitamente expulsas". Necessitamos encontrar pessoas, movimentos, ideias, acontecimentos, entidades. Contudo, é prudente lembrar, com Deleuze e Parnet (1998), que embora povoados de tribos e ocupados em arrumar essas tribos, dispondo-as de outro modo, eliminando algumas delas e fazendo prosperar outras, é preciso também levar em conta que somos desertos e que em cada um de nós há como que uma "ascese", em parte dirigida contra nós mesmos. Trata-se da experimentação sobre si mesmo, nossa única identidade.

Em síntese, há indicativos de que nos dias de hoje se engendra uma sociabilidade narcísica, compatível com as demandas do capitalismo contemporâneo. Entretanto, visualizamos forças de resistências que podem ativar as subjetividades para a construção de novos laços sociais. E isto nos leva a pensar, como Guattari (1992), que a cidade não é apenas uma questão de espacialidade, mas meio de produção da subjetividade; e o fenômeno urbano não é mais um problema dentre outros, mas "o problema número um, o problema-cruzamento das questões econômicas, sociais e culturais". E, sendo assim, o espaço urbano não poderia ser deixado ao sabor do mercado imobiliário, dos planos tecnocráticos ou ao gosto médio de seus habitantes, mesmo que sob a aparência de participação popular...

Se uma ordem mutante nas cidades em termos de novos laços sociais poderá nascer deste cenário brasileiro, acreditamos que ainda é muito mais uma questão rizomática do que arborescente, mais contágio do que filiação, mais plano de consistência do que organização, mais calçada e menos palácio, mais Lula do que FHC, quem sabe?

\section{Referências}

Deleuze, G. (1987). Proust e os signos. Rio de Janeiro: Forense Universitária.

Deleuze, G. \& Parnet, C. (1998). Diálogos. São Paulo: Escuta.

Freire Costa, J. (1986). Violência e psicanálise. Rio de Janeiro: Graal. 
Guattari, F. (1992). Caosmose: um novo paradigma estético. Rio de Janeiro: Ed. 34.

Johnson, S. (2003). Emergência. Rio de Janeiro: Jorge Zahar.

Lipovetsky, Gi. (s.d.). A era do vazio: ensaio sobre o individualismo contemporâneo. Lisboa: Relógio d'Água.

Lispector, C. (1992). Para não esquecer. São Paulo: Siciliano.

Oliveira, C. S. de. (2001). Sobrevivendo no inferno: a violência juvenil na contemporaneidade. Porto Alegre: Sulina.

Parnet, Claire. (1998). Uma conversa, o que é, para que serve? In Deleuze, G. \& Parnet, C. Diálogos. São Paulo: Escuta.

Serres, M. (s.d.). O terceiro instruído. Lisboa: Instituto Piaget.

\section{O irredutível humano: Uma antologia da liberdade}

Bader Sawaia

A primeira ideia que pode ocorrer ao leitor é de que o tema da mesa: Cultura, Individualismo e Sociabilidade, que me coube discutir nesse Encontro Nacional da ABRAPSO, não é polêmico ou representa uma novidade no debate acadêmico. De um lado, porque há consenso em torno da ideia de que a cultura e a sociabilidade das sociedades contemporânea, dentre elas o Brasil, são marcadas pelo individualismo. De outro, porque não há necessidade de pesquisas ou profundas reflexões teóricas para demonstrar que o individualismo é modo de subjetividade dominante.

Todos nós sofremos no corpo e na mente os efeitos desse Zeitgeist, na forma de solidão, associativismo utilitarista, relações voláteis, liberdade solipsista do antes de tudo vem você, nas rupturas de laços comunitários e no enaltecimento do sufixo auto. ${ }^{1}$ Pesquisa, realizada, em 1997, pelo Jornal Folha de São Paulo, concluiu que 95\% dos brasileiros são felizes, no entanto, segundo análise feita por Janine Ribeiro (1997), ${ }^{2}$ o sentimento de felicidade ao qual a pesquisa se refere é exclusivamente individual, que não abre espaço ao outro e independe do bem-estar alheio, tanto que os entrevistados julgam que o resto da sociedade é infeliz e que o outro pode até ser feliz, mas esse fato não contribui para a deles.

Os dois palestrantes apresentaram com riqueza de detalhes as formas atuais de manifestação do individualismo, ressaltando a sua incrível capacidade para inovar-se e (re)apresentar-se a cada vez com mais sutileza e perversidade. Com essas reflexões, eles nos despertam da tranquila sensação de se estar em terreno conhecido. Quando pensamos conhecer seus sintomas, o individualismo nos surpreende com novas manifestações ou dimensões desconhecidas, como a citada pelo Prof. Francisco para afirmar a tese do predomínio da "ética da independência" e do "corpo esquizofrênico": as pessoas se relacionam para ter mais saúde, o que significa que a relação com o outro é apenas um meio e não mais um fim em si mesmo.

\footnotetext{
${ }^{1} \mathrm{O}$ individualismo é bem retratado no refrão da música que fez sucesso no final de 2003 :

"Tô nem aí, tô nem aí. Não vem falar de seus problemas que não vou ouvir".
}

${ }^{2}$ Renato Janine Ribeiro, Caderno Mais, Folha de São Paulo, 25/05/97. 
Eles também destacaram o desafio, que eu considero o mais importante que o tema da mesa contém, em torno do qual não há consenso:

Como romper a causação circular entre cultura, sociabilidade e individualismo? Ou na expressão usada pelos expositores: como escapar da "captura" do encontro bloqueado e fabricado com interesses individualistas?

Ambos concordam e eu concordo com eles de que, a par dos bloqueios, existem forças de resistência ou de escape. forças.

Aqui, começamos a nos diferenciar em relação ao estatuto dessas

Para enriquecer o debate tão bem alimentado pelos palestrantes passo a apresentar uma concepção que fui buscar na ontologia, um pressuposto fundamental das Ciências Humanas, porém negado, especialmente, nas teorias psicológicas por ser confundido com metafísica, conhecimento combatido pela ciência nas reflexões sobre o Homem.

Defendo que uma forma de quebrar a circularidade, alimentadora do individualismo e suas metamorfoses, é introduzir nela a ideia de irredutível humano, o que significa recuperar a ontologia na reflexão psicológica.

Porém, antes de iniciar tal reflexão, é importante ressaltar o perigo, embutido no conceito de cultura, à ideia de resistência e de escape da captura de nossa subjetividade. Trata-se do risco da naturalização e reificação da cultura como causa e explicação do fenômeno psicológico e como parâmetro da ética, o que significa adotar as variações culturais como o único princípio a orientar o que é justiça social, como se não houvesse nada além dela e o humano fosse uma construção que varia infinitamente, a depender da diversidade das manifestações culturais. A primeira forma pode ser denominada de culturalismo e a segunda de relativismo ético.

O medo (real) da concepção de natureza humana embutido na ideia de universal levou a Psicologia Social — um ramo da Psicologia que nasceu com a preocuparão de salientar a interação psiquismo e sociedade - a jogar a criança com a água do banho, isto é, a matar de diferentes formas o sujeito como força de expansão e ultrapassagem das determinações sociais e culturais, que põe finalidade à história, embora nem sempre a realize como deseja.
O combate necessário às explicações naturalizantes e cristalizadas eliminou das análises da relação homem/sociedade tudo que tem importância na definição da pessoa como potência de vida e criação, justamente a qualidade que quero ressaltar neste texto como potência de transformação social e que estou denominando de "irredutível humano". Paralelamente, com a eliminação da ideia de sujeito, deslocou-se a critica social e a prática transformadora dos esforços dos homens para perseverar na sua humanidade, direcionando-as, exclusivamente, às estruturas e aparatos construídos pelos homens, que, assim, reificam-se.

Falar em cultura não é novidade nas Ciências Humanas e na Psicologia Social, ela é introduzida, junto com a razão, no corpo teórico dessas ciências como conceito libertador do homem de seu aprisionamento às leis naturais e transcendentais (natureza $\mathrm{x}$ cultura), cujo ápice foi $\mathrm{o}$ Iluminismo. Cultura representava a vitória do homem sobre as calamidades naturais e sobre os seus impulsos irracionais, bem como uma crítica aos princípios éticos transcendentais.

Também foi ideia libertadora na denúncia ao colonialismo e imperialismo ideológico de nossas teorias, nos anos 60. Mais recentemente, nos anos 90, cultura readquire forca teórica na Psicologia Social, na forma de defesa do direito à diversidade e contra a imposição de modelos universais únicos — o paradigma do um.

Porém, paralelamente às oportunidades, como já dito, essa categoria analítica carrega riscos.

Lembro-me do entusiasmo libertador que me arrebatou ao deparar com as teorias culturalista e historicistas que demonstravam a influência da cultura e da história sobre o organismo e a psique humana. Não estávamos presos às leis naturais, nem mesmo às referentes às diferenças sexuais.

Porém, também me lembro de como fui despertada desse maravilhamento onipotente pelo debate entre os culturalistas e a teoria social marxista. Esta última tira a ingenuidade da cultura ao inseri-la na luta pelo poder e conflito de interesses. Com ela aprendi que a própria descoberta da determinação do meio sobre o homem é apropriada como estratégia de manipulação política, transformando-se em ideologia. Um exemplo é a teoria higienista, que procura intervir no corpo e nas mentes em programas de moralização adaptativa, outro, são as teorias racistas, que 
usam a concepção da determinação cultural da subjetividade do negro, no caso da escravidão, para justificar o racismo, pois, uma vez construído o homem, é necessário séculos e gerações para eliminar a influência cultural, nele interiorizada.

Moscovici, em entrevista recente, ${ }^{3}$ sintetiza a ambiguidade da construção cultural da subjetividade, ao afirmar que a descoberta da cultura é fundamental para nos livrar das leis da natureza, mas ela nos atrela às contingências e ao acaso.

$\mathrm{Na}$ falta de uma ontologia que defenda o principio da universalidade do humano, ao nos libertamos das leis naturais, somos aprisionados pela cultura, que se inscreve impiedosamente e definitivamente em nossa subjetividade e sociabilidades, como se fossemos tabula-rasa e a cultura se naturalizasse em nós.

Somos determinados culturalmente, sim, só que esta determinação não nos constrói a partir do zero.

Se não existe nada além da cultura e das redes de sociabilidade dominantes, onde está a liberdade? Se somos produtos da cultura e da sociabilidade, não há ontologia e tudo se desmancha na incomensurabilidade das contingências e dos acasos.

No culturalismo e no relativismo ético, a liberdade resume-se aos direitos humanos, culturalmente, definidos e o sujeito se confunde com eles ou com a ausência deles. Talvez, por isso, assiste-se, atualmente, a uma sobrevalorização do direito e uma desvalorização da ontologia, o que por sua vez, favorece a nossa submissão aos sentidos, culturalmente,

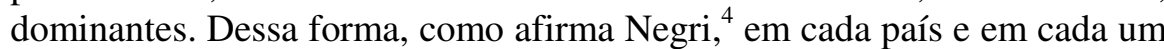
de nós há pretexto para que os direitos humanos não sejam respeitados em nome de outros valores considerados mais elevados.

Enfim, ao tentar superar a naturalização e a metafísica, pode-se cair no niilismo ou no inferno das diferenças que sustenta a retórica ética, na forma do relativismo ético e de uma de suas faces, sempre reavivada: a do colonialismo, que, atualmente, é exemplificada pela ética colonialista pós-

\footnotetext{
${ }^{3}$ Caderno Mais da Folha de São Paulo, set. 2003.

${ }^{4}$ Entrevista ao Caderno Mais do Jornal Folha de São Paulo. 12/11/2003.
}

moderna da política americana, que se arvora em arauto da democracia, responsável em levá-la aos países que não as tem, como se ele fosse o povo detentor do valor universal.

Essas duas propostas de ética na pós-modernidade, ao estilo colonialista e relativista, apesar das diferenças tem o mesmo efeito - a radicalização do particularismo e a lógica disjuntiva que é a base do fundamentalismo e do etnocentrismo dominante do pensamento ocidental, os quais separam a humanidade em identidade culturais, sociais, nacionais, grupais e individuais, impedindo-nos de compartilhar as riquezas gerais da universalidade humana, alerta. ${ }^{5}$

Dois eventos, ocorridos no segundo semestre de 2003, embora de ordem diferente, simbolizam iniciativas para dar um basta ao relativismo ético, que tolera o intolerável em nome da diversidade cultural. Um é a libertação de Amina, condenada a morte por apedrejamento na Somália, por ter sido acusada de infidelidade, contrariando a moral local. O outro, é a outorga do prêmio Nobel da Paz, a uma mulher muçulmana, a advogada iraniana Shirin Ebadi, que defende a liberdade da mulher muçulmana. O prêmio significa a retirada dos direitos das mulheres da chave da cultura e sua colocação na ordem universal, no irredutível humano, que atravessa o mundo islâmico e católico.

Em síntese, o grande perigo do culturalismo é o de eliminar, das análises e teorias psicossociais, o universal que, paradoxalmente, explica a singularidade e, assim, tornar-se uma outra forma de naturalização que elimina do homem a possibilidade de criação e singularidade.

Em nome da cultura, exclui o universal humano, o que pode redundar na indiferença ou intolerância para com o outro, caminho que leva ao individualismo e ao seu contraponto à segregação. Se não somos os mesmo em todos os lugares, não temos nada em comum, as diferenças se transformam em in-deferença. O outro é tão outro, quase de outra espécie, o que impede o compartilhar. O futuro é incerto, incomensurável e contingente, podendo ser a decadência sem a possibilidade de nova síntese,

\footnotetext{
${ }^{5}$ Tese defendida por Edward Said. Palestino, que foi prof. da Universidade de Columbia. NY, por 40 anos. Ver Said. E. W. (2003). Cultura e Política. São Paulo: Boitempo Editorial.
} 
ou um exercício de construção aleatória e infinita do homem, uma ameba que vai adquirindo as formas do que a afeta.

As Ciências Humanas sempre tiveram dificuldade de trabalhar estas questões. Sua história é atravessada pelo falso debate entre cultura e natureza (nurture $\mathrm{X}$ nature). Muitas de nossas teorias resolveram o problema, distribuindo porcentagens diferentes ou, salomonicamente, $50 \%$ a cada uma na constituição do homem.

Eu prefiro a estranha porcentagem defendida por Morin (2003) que define o homem como $100 \%$ cultura e $100 \%$ natureza ou a de Boaventura (1988), que afirma não haver natureza, uma vez que toda a natureza é humana, pois ambas superam a cisão entre natureza e cultura.

Mas só este postulado não é suficiente para responder à indagação comum aos expositores da mesa: "Como escapar da captura do individualismo?".

A minha resposta é de que é necessário uma ontologia positiva para recuperar a ideia de universal. Que contêm aquilo que é importante na concepção de homem como potência de criação e ação e que é indestrutível, a despeito de todo esforço despendido pela história e pela cultura. Essa potência é o que denomino de o "irredutível humano".

\section{O irredutivel humano e a determinação social}

Encontrei em Espinosa, filósofo monista do século XV, que se contrapunha ao dualismo cartesiano, uma ontologia que cicatriza a cisão clássica entre natureza e cultura, apresentando uma concepção de irredutível humano não essencialista.

Há uma frase dele na Ética que sintetiza tal postulado: “A essência é livre, mas a existência é determinada", o que significa que todo ser existe para perseverar na própria substância, adquirindo eficiência ou não para tanto, na existência, que é determinada historicamente. A tensão entre liberdade imanente e determinação existencial, explica as variações singulares do irredutível humano.
Para entender tal postulado é preciso completá-lo com: 1) a reflexão espinosana de sobrevivência, 2) o conceito de potência que ele usa para descrever tal processo e 3) a relação potência e afeto.

Sobreviver é mais que conservar-se vivo, é expandir-se, sendo que a expansão exige liberdade e criação. E o que é mais importante, essa força de expansão da vida é potência e não deiscência, o que significa que ela não é uma tendência natural que vai, inexoravelmente, amadurecer. Ao contrário, a potência de vida é aumentada ou diminuída nos encontros com outros corpos e mentes, sofrendo a ação das ideias, superstições e ações do outro, quer no sentido de maior autonomia, quer de heteronomia.

Daí a sua afirmação de que a essência tem a propriedade de ser, mas o quanto eu o serei, é estado existencial (Espinosa, 1957, p.7).

Quando sentimos que nossa potência de ser é aumentada, a emoção que nos afeta é de alegria, quando, ao contrário ela é diminuída, somos afetados por emoções tristes. As primeiras são mais fortes e favorecem ações emancipadoras, as segundas, colaboram com a servidão. $\mathrm{O}$ irredutível humano é essa potência vital de conservação e expansão, portanto, de liberdade e felicidade. Uma potencialidade em ato, que se realiza nos encontros, pois é da natureza do corpo e da alma ser afetado e afetar.

Tal ontologia é um antídoto ao individualismo, ao livre arbítrio e ao predomínio atual do prefixo auto: autoajuda, autoestima, que Espinosa qualificaria de superstição ou ideia inadequada, pois sem os outros não ocorrem encontros e a potencia do eu não se concretiza. A necessidade do outro, por sua vez, não significa colocar-se na dependência de outra pessoa ou objeto. Ao contrário, ele afirma que depositar a esperança de felicidade em pessoas ou forças fora de mim e acreditar que a felicidade está na obtenção de coisas perecíveis, como um grande amor ou a posse de um bem valioso, promovem o enfraquecimento da potência de ação, tornandose fonte de heteronomia.

Se fôssemos sintetizar a máxima espinosana, ela não seria igual ao de Hipócrates de que a virtude está antes de tudo no não fazer o mal, mas de que ela está na capacidade de afetar e ser afetado para aumentar a potência de liberdade e felicidade. 
"Somente as pessoas livres sã gratas uma às outras e procuram ligarse pelos fortes laços de amizade" (Espinosa, 1957, livro IV). As servis, quer as que usufruem e se submetem, ligam-se por recompensa, medo ou fúria e se submetem a fundamentalismos, mesmo que a experiência mostre que estão errados, perderam a capacidade de afetar a serem afetados, a maior virtude.

Ele qualificaria o bloqueio dos encontros como a principal estratégia de captura dos processos de subjetivação ao individualismo.

Professor Francisco apresentou, com muita riqueza de detalhes, a forma contemporânea de manifestação desse bloqueio, que ele denomina de "biossociabilidade", processo em que o corpo é valorizado, mas bloqueado ao encontro e dessa forma é afetado, não pelo outro, mas por cadeia imaginária de ideias que vão produzir nossos afetos.

Todos somos capazes de sentir no dia a dia que saímos diferente a cada encontro, quer seja com uma flor, com uma notícia, com um amigo, por exemplo. Saímos mais alegres ou mais tristes. Esta capacidade de afetar e ser afetado é condição do ser e existir e não estado psicológico ou constructo linguístico e explica a passagem da passividade à atividade, da autonomia à heteronomia.

Com essa análise, Espinosa apresenta a sua concepção de ética imanente aos afetos, a qual carrega importante implicação prática e teórica para a psicologia, a de que os princípios de constituição dos mesmos são ontológicos e não variáveis a serem controladas ou eliminadas por esforço do próprio homem ou da sociedade. Na filosofia espinosana, os afetos são éticos e políticos porque constituem o fio que costura a tessitura das relações democráticas ou servis, da autonomia e da heteronomia.

A afirmação de que há uma relação positiva entre o poder que tem um corpo de ser afetado e a sua potência de agir (Hardt, 1996, p. 98), eticamente, é uma das ideias mais ricas de Espinosa à práxis da Psicologia Social e à discussão dos direitos humanos, bem como a de que essa potência se realiza em atos, determinada pela história e pela cultura. Esse último postulado explica a passagem universal/particular/particular, ou seja, porque eu sou necessariamente humana e sou brasileira por contingências históricas e culturais. Sintese final: o irredutível humano e o confronto entre
individualidade e individualismo

Todos sabemos que liberdade é melhor que servidão. A dificuldade está em definir o que consiste a liberdade e quem deve merecê-la.

Para Espinosa esta dificuldade não existe, pois ele não defende princípios. No seu entendimento, eles são imanentes à substância humana, portanto, sem eles não há homem. Não há o bom e o mau. O bom é o que compõe como meu corpo e mente, potencializando a autonomia e o mau é o que favorece a heteronomia, ao enfraquecer o meu conatus. ${ }^{6}$

Portanto, potência é a dimensão irreprimível de luta pela emancipação.

Esta concepção impede que se criem critérios mirabolantes para definir quais ações, culturalmente delimitadas, são éticas, uma vez que ela não é contingente às determinações sociais, ao contrário, é imanente às afecções do corpo e da mente, o que significa que é imanente às necessidades de conservação e expansão da própria substância. Esta proposição fica bem clara na critica que Espinosa faz à ideia de livre arbítrio, qualificando-a de falsa, uma vez que a vontade não é livre, mas movido pela essência e a potência do ser. O livre arbítrio é, na verdade, a escolha entre possíveis colocados pelo exterior.

Dessa forma, Espinosa apresenta uma concepção de ética não contingente a retóricas e variações culturais, bem como não transcendente ao homem, mas imanente a ele, constituindo-se, portanto, em um irredutível humano. O fundamental dessa ontologia é a afirmação que ética, poder e afeto são coextensivos.

Neste momento, o leitor pode contra-argumentar que a ontologia do irredutível humano é metafísica e amarra a Psicologia às leis gerais.

Eu discordo e considero que tal argumento precisa ser discutido em duas perspectivas. Uma, de forma geral e outra, especifica a abordagem ${ }^{6}$ Conatus é conceito usado por Espinosa para se referir ao desejo de vida do corpo e da
alma, ao esforço para se conservar na existência. 
espinosana. A primeira refere-se ao valor negativo atribuído à metafísica nas ciências humanas, como se a afirmação de princípios universais fosse, necessariamente aprisionante. Com relação a esta questão, em vez de responder, lanço uma pergunta ao leitor, porque já foi bastante discutida no início: Afirmar que todos somos iguais por natureza não é pressuposto mais libertador do que o culturalismo que nos amarra ao destino social e cultural? Não é esta ontologia que sustenta, por exemplo, a luta pelos direitos iguais das mulheres, contra as diferentes versões culturais da inferioridade feminina?

A segunda perspectiva consiste em ressaltar a oportunidade que Espinosa oferece às ciências humanas e sociais de sair do impasse atual que designa como única saída possível à crise do universalismo, a incomensurabilidade, a fragmentação e o relativismo na forma de negação de qualquer princípio humano. Para ele, não há antagonismo, entre universal. singular e particular, pois particular representa o conjunto das experiências, socialmente determinadas, que medeiam a singularização em ato do universal.

Por isso, o estado existencial é mais amplo que a essência, podendo adquirir força de aprisionamento do homem à servidão, o que só pode ser combatido pela união de conatus.

Porque se, por exemplo, dois indivíduos inteiramente da mesma natureza se aliam, um ao outro, compõem um indivíduo duas vezes mais poderoso que cada um, separadamente. Nada, pois, existe, mais útil ao homem do que o homem; os homens, digo, não podem desejar coisa mais valiosa para a conservação de seu ser, do que conviverem todos em tudo, de maneira que as almas e os corpos de todos, componham, de certa maneira, uma só alma e um só corpo, esforçarem-se em conjunto por conservarem seu ser e procurarem todos reunidos a utilidade comum a todos... (Ética, livro IV, PXVIII).

Dessa forma, ele afirma a essência sem ser essencialista e afirma o universal sem atrelá-lo a leis, apresentando uma ontologia que nos igualiza, sem uma presunção epistemológica de agrupar todos os fenômenos deste mundo em torno de uma grande teoria.

A sua analise dos afetos e a sua doutrina que cada pessoa necessariamente se esforça por perseverar em seu ser, oferecem, junto com sua ontologia monista e sua teoria do conhecimento, a base para a explicação da possibilidade de fuga da captura tanto das leis da natureza, quanto das leis culturais. Desde que os seres humanos se esforçam, necessariamente para perseverar na existência de seu ser e também se esforçam para prevenir qualquer depressão no poder de agir e se esforçam para aumentar esse poder, todos eles serão motivados, segundo seu próprio poder permite, a perseguir o bem para esta força.

Aqui, cabe ressaltar que esta proposição espinosana tem sido interpretada, erroneamente, na minha opinião, como uma apologia do egoísmo. A ênfase na ideia de que cada coisa, necessariamente, se esforça por perseverar em seu ser e que o desejo é sempre dirigido ao próprio beneficio, é analisada por muitos como uma doutrina do necessário egoísmo individual psicológico, que atravessa toda a natureza (Garret, 1997, p.6).

O erro desta interpretação, no meu entender, consiste na incompreensão de que para Espinosa, o próprio benefício implica o beneficio ao outro. O conatus individual se fortalece nos encontro e é só neles que ocorre a transição dos afetos e, portanto, da passividade à atividade e vice-versa. Portanto, o desejo do comum é uma necessidade para aumentar o poder de ação.

A sua teoria política ${ }^{7}$ é exemplo desta proposição, pois reafirma que os homens se juntam para aumentar a potência para enfrentar as forças externas do estado de servidão e heteronomia, colocando a gênese da sociedade, não no desejo de evitar a dor ou controlar a maldade inata. Os homens criam a sociedade e as leis motivados pelo desejo de realizarem as necessidades imanentes à sua substância.

Aí reside nossa aventura comunitarista: a energia fundadora do laço social está no desejo de aumentar o conatus, a qual é capaz de explicar porque nenhum momento da história conseguiu anular a capacidade humana de criação de caminhos de fuga.

\footnotetext{
${ }^{7}$ Ele concordava e combatia Hobbes ao mesmo tempo. Sobre esta questão ver Almeida. M. da Conceição de. (2002. jun.). Borboletas. homens e rãs. In Margem. São Paulo. no 15.
} 
Sem esta ontologia do irredutível humano, as lutas e resistência viram voluntarismo, reificação, invenção de mitos e heróis.

\section{Referências}

Alves, J. L. (2001). A individualidade Moderna nos Grundrisse. In Ad Hominem (n. I, tomo IV). São Paulo: Estudos e Edições Ad Hominem.

Arendet, H. (1993). A condição humana, (6 ${ }^{\mathrm{a}}$ ed.). São Paulo: Forense.

Espinosa, B. (1670/1988). Tratado teológico-político. Lisboa: Imprensa Nacional-Casa da Moeda.

Espinosa, B. (1677/1957). Ética, (4 ${ }^{\mathrm{a}}$ ed.). São Paulo: Atenas.

Espinosa, B. (1677/1977). Tratado político, (2 a ed.). Lisboa: Editorial Estampa.

Della Rocca, M. (1997). Spinoza's ethical theory. In D. Garret (Ed.). The Cambridge Companion to Spinoza. New York: Cambridge University Press.

Garret, D. (Ed.). (1997). Introduction of Garret, D. The Cambridge Companion to Spinoza. New York: Cambridge University Press.

Hardt, G. (1996). Gilles Deleuze — um aprendizado em Filosofia. São Paulo: Ed. 34.

Souza Santos, B. de (1988). Um discurso sobre as ciências, (2 ${ }^{\mathrm{a}}$ ed.). Lisboa: Edições Afrontamento.

Morin, E. (2003, dez.). Revista Margem, Faculdade de Ciências Sociais da PUC-SP, 15.

Sawaia, B. B. (1998, jul./dez.). A crítica ético-epistemológica da Psicologia Social pela questão do sujeito. In Psicologia \& Sociedade, 10, 2.

Sawaia, B. B. (2003). Para não esquecer do irredutível humano: a subjetividade como ideia reguladora da reflexão sobre direitos humanos e exclusão/inclusão. Cadernos. Brasília: Conselho Federal de Psicologia.
SIMPÓSIO 5 - A CIDADE COMO TERRITÓRIO DE CRIAÇÃO

\section{Imagem e cidade: trilhas juvenis}

Glória Diógenes

Viemos de um caos onipotente, de um denso e indissolúvel abismo de luz e trevas. E pelejamos todos - plantas, animais, homens $e$ ideias - na brevíssima passagem de nossa vida individual, para ordenar o caos dentro de nós, para iluminar o abismo, para converter em luz, dentro de nossos corpos, toda a treva possivel.

(Nikos Kazantzakis)

Relatos da cidade e do bairro ou como seguir pistas de trajetos nômades

Aguço os ouvidos, planto balizas, farejo o vento (...) me arrastando, arquejando, mas ascendo. $\mathrm{O}$ grito ordena em mim a mobilização. ${ }^{1}$

Sigamos Lobão. Rapper, participante do movimento hip hop, da rádio comunitária do bairro, dançarino de break, ex-pichador, educador social do Centro Comunitário do Morro, mestre de briga de galos, soltador de arraia, ${ }^{2}$ integrante da banda Conscientes do Sistema e articulador comunitário da Ong Enxame. ${ }^{3}$ Lobão não pára. O morro do Lobão e o

\footnotetext{
${ }^{1}$ Adaptação do texto de Nikos Kazantzakis por Daniela Visco, Letícia Spiller e Jac Fagundes.

${ }^{2}$ Pipa no Ceará.

${ }^{3}$ O Enxame (apoiado pela Fundação MacArthur. UNICEF. BNDES. e Instituto Ayrton Senna), projeto coordenado por nós, tem como proposta trabalhar Artes Visuais com gangues e galeras de rua. O objetivo é canalizar a pulsão da violência para produção da arte e para campos de resignificação de valores e atitudes no âmbito da estética juvenil. Ele teve início em setembro de 2000 e conta com a participação, fixa, de 40 jovens. Todo o trabalho etnográfico apresentado a seguir, foi realizado com 8 (oito) participantes do Enxame em uma oficina denominada: "Diz por onde andas e dirás quem és". Ele foi desenvolvido em cinco momentos: a) Figurações do bairro e da cidade: lugares significantes (colagem e
} 
morro da Cidade de Fortaleza, situado no bairro do Mucuripe, projetam-se como mapas que parecem ter sofrido alterações nos seus limites, no traçado de suas vias, na disposição dos equipamentos e nos usos e desusos do espaço urbano. É bom lembrar, estamos em Fortaleza. De cima do Morro Santa Terezinha, podemos ver a orla onde se situam os principais hotéis, restaurantes, bares e os edifícios de mais alto valor especulativo no mercado imobiliário. Morro e Beira-mar parecem dar corpo à alma da cidade: lugar de nítidos contrastes e de linhas demarcatórias de uma visível segregação espacial.

Do Morro, Lobão sabe da Cidade, capta seus sentidos e parece perceber que é preciso refazer, continuamente, um lugar que tem pretensões de fixidez, de ordenamentos que atrelariam os indivíduos a trajetórias "oficiais"; casa/trabalho; casa/ igreja, casa/baile, dentre outros. Lobão parece traçar, a cada percurso, um ato de delinquência. Como diz De Certeau (1994, p.215) "onde o mapa demarca, o relato faz uma travessia". As linhas de passagem no Morro traçados por Lobão, como caso exemplar, mobilizam sentidos da cidade, signos silenciados, produzindo leituras e novos campos de apropriação urbana.

As imagens da cidade, embora visíveis, prescindem do olhar do observador, da relação que cada um mantém com o espaço, das suas usanças. $^{4}$ A exposição de imagens, aos olhos dos passantes, apenas atiça sentidos, mobiliza vontades de decifração se evocam registros de memória fincados no lugar-corpo. Como lembra Marc Augé (1994, p.81), "existem espaços onde o indivíduo se experimenta como espectador, sem que a natureza do espetáculo the importe realmente". Quando o percurso inspira

desenho); 2) Olhares sobre o lugar: registros visuais (fotografias do Bairro); 3) Foram realizados três percursos narrativos: Sede do Enxame-casa-Lobão; Sede-casa de Mira; Sederota de tráfico de Leo. Para o escopo dessa publicação; será narrado apenas o trajeto de Mira.

${ }^{4}$ Lucrecia Ferrara adverte que "Para o usuário, o uso é o modo de reconhecimento ambiental e a lembrança que dele conserva é, antes de tudo, uma predicação do ambiente. Esta predicação ambiental, lembrada pelo usuário, substitui o próprio espaço e confere ao uso um caráter de permanência cotidiana e rotineira. Esta continuidade nos permite substituir o termo uso por usança com um caráter de mediação entre o espaço ambiental e o usuário. Desse modo, hábito e uso se incorporam e se confundem, e a usança surge como verdadeiro signo de um hábito". O Olhar Periférico, 1993, p.21. relatos, o corpo do narrador faz emergir o topos cidade desenhado no campo de suas produções imaginárias. Os percursos incitam os sentidos e signos da cidade arquivados no corpo. É que a memória é topográfica, ela precisa fazer emergir o lugar para reconstruir as teias da experiência. ${ }^{5} \mathrm{O}$ corpo é mapa das lembranças.

O corpo de Lobão faz fervilhar imagens do bairro e da cidade. ${ }^{6}$ Realizar percursos no bairro, na vibração de um andante/narrador como Lobão, é mover-se através de marcos de experiência que já se encontram cartografados no seu corpo. É assim que a cada lugar Lobão assume nomeações diversas: ele é Def, palito, chuchu, Junior e, propriamente, Lobão. Interessante o relato acerca da mudança que se efetiva na forma de mover seu corpo, na composição de sua gestualidade nos seus vários espaços de nomeação.

Quando entro na minha rua já vou logo soltando o corpo. Fico todo ameninado, deixo esse meu jeito de líder do bairro, não dou conselho a ninguém. Sento na calçada e sei que ali eu sou o Chuchu. Brinco e grito igualas meus primos, meus amigos "das antiga". Ali, não sou modelo pra ninguém. Até meu olhar muda.

Os signos visuais que pontilham o bairro e mobilizam a leitura do narrador, têm como lugar de enunciação o corpo do passante. A comunicação urbana utiliza como suporte o corpo do narrador. "A narração não visa como a informação comunicar o puro-em-si do acontecido, mas o incorpora na vida do relator, para proporcioná-lo como experiência, aos que escutam. Assim, no narrado, fica a marca do narrador, como a impressão do oleiro sobre o pote de argila" (Benjamin, 1975, p.40). Os percursos realizados com Lobão e mais seis integrantes do Enxame fizeram emergir relatos que proporcionavam a nítida impressão de que as marcas, cicatrizes, as pichações, os becos, a rua-arquibancada, a torre; as

\footnotetext{
${ }^{5}$ Lembra Bachelard que "Por vezes acreditamos conhecer-nos no tempo, ao passo que se conhece apenas uma série de fixações nos espaços de estabilidade do ser, de um ser que ainda não quer se passar no tempo, que no próprio passado, quando sai em busca do tempo perdido, quer "suspender" o voo do tempo. Em seus mil alvéolos, os espaços retém o tempo comprimido. E essa a função do espaço", A Poética do Espaço, 1998, p.28.

${ }^{6}$ Uma alusão a afirmação de Lucrecia Ferrara que "a cidade é um império fervilhante de signos", Máscaras da cidade, 1990, p.3.
} 
sensações narradas como experiências significantes, fundiam a obra e mestre, o pote e oleiro, a cidade e o corpo.

A intenção do percurso realizado com integrantes do Enxame, que será detalhado a seguir, se propunha a garimpar, a fazer emergir, signos visuais que contam a história do bairro e da cidade e que assumem um lugar significativo no imaginário dos jovens que residem no Morro Santa Teresinha. Eu funcionava como guia teleguiada pelos itinerários e lugares percorridos e que faziam emergir a história do bairro e das experiências do grupo. Pode-se dizer que, obviamente, eu ali, me movia acionada pela vontade de percorrer mapas de sentidos do vivido de cada um, mas, essencialmente, animada por uma vontade de interpretação. Desse modo, adentrava uma outra cidade nos caminhos percorridos através dos olhares e percepções dos enxamistas. ${ }^{7}$ Em seus percursos, realizava um feixe de leituras acerca dos signos que passavam em exposição. Lembrava, nos trajetos, que "a leitura não-verbal é uma maneira peculiar de ler; visão/leitura, espécie de olhar tátil, multissensível, sinestésico" (Ferrara, 2000, p.26). Experimentava um pedaço da cidade. De algum modo, o compasso do meu trajeto era marcado pela ideia de "reconhecer que o visual, sua hierarquização como instância na representação icônica, não exige que desapareça a escrita, a linguagem verbal, mas implica numa função conquistada, a estética, que da palavra faz imagem" (Silva, 2001, p.8). De outro modo, da vontade de dizer, de praticar cidade, ${ }^{8}$ da imagem fazer emergir a palavra. A diferença é que nós nossos percursos a imagem não necessariamente se localizava no lugar-bairro, no lugar-cidade ela poderia projetar-se a partir de um signo registrado no corpo. José Gil (1995, p.212) nos faz lembrar, através de uma interlocução com a obra de Freud, da função significante do corpo. Segundo ele "convirá atribuir um importante papel ao corpo, a sua aptidão para emitir e receber signos, para inscrever em si mesmo, para os traduzir uns nos outros". Se não podemos pensar sem signos, ${ }^{9}$ se a cidade é um espaço de representação certamente, o significantecidade não estaria fincado nos seus marcos, nas suas ruas, praças e sim nos registros que habitam os lugares de memória no corpo do narrador.

\footnotetext{
${ }^{7}$ É como os jovens que fazem parte do Enxame se autodenominam

${ }^{8}$ Michell de Certeau, A Invenção do Cotidiano, 1994.

${ }^{9}$ Lucrecia Ferrara, Leituras sem Palavras, p.7.
}

A diferença do Lobão pro Chuchu é porque o Lobão, as pessoas veem com muito respeito, né, e vê como um artista, e aqui não; eu me sinto à vontade de não tá tendo que se preocupar com o que eu tô falando, com a postura, tá passando informação, aqui eu não tenho que passar nada. Aqui eu sou, eu sou um nada, sou o Chuchu, simplesmente Chuchu, sem compromisso com nada e aí quando eu quero, quando eu tô estressado, que eu quero fugir de tudo, eu pego, tranco aqui a sede e vou lá pra rua e sento no meio da rua

O significante nada parece desnudar Lobão da ordem dos papéis e atribuições sociais compactuadas no bairro. Em um momento da caminhada, quando adentramos a rua e alguém gritou, Chuchu, Lobão parecia ter deixado para trás os signos da consciência, do corpo como suporte de uma moral tanto referida nos seus raps. Ali, ele voltava à infância, era menino. Na rua da família, um outro corpo pôde emergir.

Caminhamos pelo bairro sabedores de que para os Jovens da periferia, que praticam cidade ela se desvelaria, se animaria, com o fluxo das narrações. "Praticar espaço é, portanto repetir a experiência jubilatória e silenciosa da infância. É, no lugar, ser outro e passar ao outro" (De Certeau, 1994,p.191). Assim atravessamos o lugar do Def, as antigas inscrições de Palito, a rua do Chuchu, a casa do Junior e o bairro de Lobão:

A rua que eu moro, né, outro mundo, porque lá não existe Lobão não (...) lá não existe consciência, lá não existe projeto Enxame, lá é Chuchu. Chuchu é meu apelido. Meu apelido. Meus primo ligam pra mim, não precisa nem dizer quem é, diz chuchu, já sei que é da minha família. Essa rua aqui por incrível que pareça, toda ela é da minha família e não é pequena não. Toda, dum lado e outro. Primo, tia, irmão, (Sonic - Já fui lá na tua casa lá) pois é tudo gente da minha família. Que é que acontece ... Ah, aqui é que eu descubro tudo, quem morreu, a doidinha que tá buchuda, quem "comeu", a outra que virou sapatão, isso aqui, ó, a galera tudinho quando eu tô lá, vem me dizer: ó, cumpade, fica ligado, aquela doidinha que é só massa, agora não é sapatão? Diz aí doido que deram uma furada no teu ex-cunhado, viche, o cara quase morre, dava pra entrar era uma mão. Joãozinho bora lá, pra tu vê como é que tá, não sei quê e tal. Isso aqui é a rua, quando eu chego lá, é outro mundo.

Caminhar é um modo de fazer o corpo atravessar os acontecimentos do bairro, de localizar nomeações públicas, posses afetivas do espaço. 
Todas as nossas caminhadas pareciam fazer acordar uma energia inquieta, com um sentido de aventura, de ousadia, de brincadeira; como quem realiza algo não permitido, ou não coadunado com a nossa condição presente. como uma não consciência. Estar de bobeira, numa manhã ensolarada de um dia de quarta-feira, na rua de Lobão parecia contrariar os ritos costumeiros da Cidade. Caminhar tinha uma cadencia de festa, de celebração, de uma comunicação que flui direta, colada à lógica do acontecimento. Tentando decifrar essa alegria, esse outro mundo, que parecia mobilizar o corpo de Lobão e de quem o escutava nos trajetos, percebi, que andávamos sem finalidade específica, pura fruição do corpo no tempo. Como diz Duvignaud (1983. p.66) "a festa não implica em qualquer finalidade senão ela mesma". Além disso, seguir trajetos pessoais, rotas de histórias de vida significa pontilhar trilhas, provavelmente, descontínuas. "Produzir descontinuidade é desfazer linearidade e ler por saltos revelando o imprevisto recorte inovador que permite que se aproxime duas ou mais imagens, antes desconexas" (Ferrara, 2000, p.126). A rua do Chuchu efetua um salto na lógica disciplinar dos espaços da metrópole. A rua do Chuchu, despadroniza a conduta pública, instiga a projeção de um inusitado personagem urbano e, paradoxalmente, possibilita e movimenta a existência de Lobão.

Nesses trajetos, produzem-se desvelamentos, exibições, encontros fortuitos, aparições dos lugares que já são outros, nos lugares da memória; caminhar faz acordar os corpos artífices da cidade, corpos que movimentam cidades. Caminhar pode significar transmudar a lógica rotineira do deslocamento para itinerários de delinquência. "Se o delinquente só existe deslocando-se, se tem por especificidade viver não à margem, mas, nos interstícios dos códigos que desmancha e desloca, se ele se caracteriza pelo privilégio do "percurso" sobre o "estado", o relato é delinquente" (De Certeau, 1994, p.216). Que nuances possibilitariam identificar diferenciações entre a prática do deslocamento e os ritos da caminhada? Isso porque, deslocar-se significa percorrer pontos rotineiros, linhas que unificam marcos de chegada e de partida pré-traçados, rotas oficiais.

Ela deveria evocar um movimento temporal no espaço, isto é, a unidade de "sucessão" diacrônica de pontos percorridos, e não a "figura" que esses pontos formam num lugar supostamente sincrônico ou anacrônico (...) um gráfico toma o lugar de uma operação (De Certeau, 1994).
Uma linha que integra pontos parece tecer a lógica dos deslocamentos. "Mas o nômade só vai de um ponto a outro, ainda que este ponto seja incerto, imprevisto ou mal localizado" (Deleuze e Guatarri, 1997, p.51). Onde se perfura, se torna lisa e de múltiplos contornos os atalhos que possibilitam realizar e rastrear práticas de delinquência? Que pistas nos conduziriam a becos, ruas, praças capazes de fazer emergir corpos e personagens em estado de latência?

(...) pode-se de antemão dizer que, em matéria de espaço, essa delinquência começa com a inscrição do corpo no texto da ordem. A opacidade do corpo em movimento, gesticulando, andando, gozando, é que organiza indefinidamente um "aqui” em relação a um "alhures", uma "familiaridade" em confronto com uma "estranheza" (Deleuze e Guatarri, 1997, p.217).

Os relatos de caminhada permitem inscrever o corpo em lugares "invisíveis", fundamentalmente, para os passantes que se deslocam movidos pela pressa da chegada, pela simples necessidade do deslocamento. Sennett (2001, p.214) nos seus estudos sobre "O Corpo e a Cidade na civilização Ocidental”, assinala que a circulação urbana criou uma ética da indiferença: "Hoje, como o desejo de livre locomoção triunfou sobre os clamores sensoriais do espaço através do qual o corpo se move, o indivíduo moderno sofre uma espécie de crise táctil: deslocar-se ajuda a dessensibilizar o corpo". As estratégias de ordenamento urbano, de uso e ocupação do solo, tentam eliminar o risco de pontos de contato e segundo Sennett, todas essas questões começam na carne. Isso nos faz retomar a ideia, discutida anteriormente, acerca da interligação entre a caminhada e a festa. Na festa, assim como nos jogos, "os gestos realizados à nossa frente são signos que terminamos por absorver, porque a nossa própria percepção se transmuda em apropriação" (Duvignaud, 1983, p.62). Para que isso ocorra, torna-se necessário um encontro de corpos, uma aproximação que estabeleça uma relação extra-oral, especialmente ritmada pelos movimentos, gestualidades e expressões múltiplas dos corpos no espaço. Isso se faz e se alimenta de energia, da disposição dos corpos, de sua ação táctil e muscular. Por isso o movimento do nomadismo juvenil opera mudanças no espaço da Cidade:

O espaço sedentário é estriado, por muros, cercados e caminhos entre os cercados, enquanto o espaço nômade é liso, marcado apenas 
por traços que se apagam e se deslocam com o trajeto (Deleuze e Guatarri, 1997, p.52).

É por isso que Lobão muda de nome a cada lugar do trajeto, e que cada traço-nome fincado no espaço do bairro se apaga e se acende com a sua presença. A caminhada é da ordem das intensidades, a caminhada é um rizoma mobilizado pela vontade do movimento. "O rizoma é feito somente de linhas: linhas de segmentaridade, de estratificação, como dimensões, mas também linha de fuga ou de desterritorialização como dimensão máxima segundo a qual, em seguindo-a, a multiplicidade se metamorfoseia, mudando de natureza" (De1euze, 1995, p.32). Daí o caráter errático da caminhada, nomadizador, rizomático; é que ela restabelece os lugares de contato, de produção de energia, de expansão de si, de expansão do espaço liso. Se como Sennett (2001, p.19) acreditamos que "hoje em dia, ordem significa falta de contato", a caminhada conecta sentidos, promove percursos dissidentes, faz emergir personagens sem consciência, possibilita que se sobreviva, em algumas circunstâncias, no nada.

Através das pistas de Lobão, da esquina de Mira ${ }^{10}$ e dos fragmentos de cidade e do bairro projetados através de figurações e narrações, realizadas na sede do Enxame, rastrearemos os caminhos dos corpos na produção de trilhas urbanas. Certamente, eles nos conduzirão a espaços fora do epicentro de visibilidade, de tráfego e de concentração de usos, equipamentos e serviços urbanos da metrópole de Fortaleza. Trilhas de uma cidade que nos conduz a uma curiosa estética urbana; onde falar sobre algo, significa morar em algo. ${ }^{11}$ Onde são geradas as palavras, que percursos instauram, que corpos animam, que histórias e cidades fazem emergir?

\footnotetext{
${ }^{10}$ Afora Lobão, todos os outros nomes são fictícios. Tendo em vista que o rapper Lobão, atualmente, como integrante do movimento hip hop, faz da sua história um relato público, não alteramos sua identificação.

${ }^{11}$ Juliano Pessanha, A Província da Escritura.
}

A cidade dos limites: a esquina, o muro e o corpo de mira fora calçadão

Toda a minha luta periga a cada instante, toda a minha luta periga a cada corpo. Avanço aos tropeços pela carne como um viajante surpreendido pela noite. ${ }^{12}$

Mira tem apenas 14 anos. Ela é participante "fundadora" do Enxame. É raro encontrar na cidade de Fortaleza uma negra como Mira, de cor bem escura e traços marcados. Ela se move com a determinação dos que se assumiram e parecem ter orgulho de sua diferença, numa cidade marcada pelos contrastes e por espaços bem delimitados da pobreza e da riqueza. Um dos jovens, de cor negra participante, também, do Enxame, dizia, que frequentemente, era chamado de macaco pelos policiais. Ela sabe que a sua cor se projeta como fronteira social. Mira aproximou-se do movimento hip hop,$^{13}$ tornou-se compositora de raps e frequenta rodas de break. Os outros jovens integrantes do projeto dizem sobre ela: "A Mira tem atitude". Seguir os passos de Mira foi como adentrar espaços de resistência. Iniciemos o trajeto.

A "cidade" de Mira sabe que o seu espaço de liberdade é limitado; nos seus relatos a cidade se esquiva, se contrai, delimitada por muros, cercas e espaços de segregação. É no relato de Mira que a cidade aparece confinada: "Tô sentindo que esses prédios tão prendendo muito a gente, tá tirando as periferias para fazer prédio agora". Ela sabe que os espaços de movimentação da periferia, os lugares-marco de amizade, os campos de brincadeiras ganham novas apropriações. Mira fala do "declínio dos espaços públicos" ${ }^{\prime 14}$ :

\footnotetext{
${ }^{12}$ Adaptação de texto de Nikos Kazantazakis, autoria referida na nota 1.

${ }^{13} \mathrm{O}$ movimento hip hop trabalha três elementos: o grafite, o break e rap. Ele surge, historicamente, nos guetos negros de Chicago e nos movimentos de resistência e protesto à morte de jovens na guerra do Vietnã. Tem um forte componente político, essencialmente no que tange aos aspectos de discriminação racial, de classe (força da periferia) e da cultura de massa. Para entender mais sobre o Hip Hop ver Herschmann. Michael e Diógenes. Glória. Cartografias da Cultura e da Violência. São Paulo. Annablume, 1998.

${ }^{14}$ Uma alusão à obra de Richard Sennett, O Declínio do Homem Público,1988.
} 
Deixa eu contar aqui, uma história aqui. O prédio prende assim, porque tipo assim, no beco que eu moro tem um muro, dos antigos mesmo assim, todos os pivetes ali do beco sempre brincou dentro daquele muro, aí agora não brinca mais, ninguém não pode nem passar para o outro lado, quando cai uma bola lá dentro é muito difícil você ir pegar a bola lá dentro, porque? Por causa do prédio: ali era um campo de futebol, menino, rolou muita coisa ali dentro, conta muita história, tá aqui uma pra te dar a história daquele muro ali, uma queda que eu levei lá dentro.

GD - Essa cicatriz?

Lila - É uma história daquele muro, essa cicatriz aqui foi uma queda que eu levei dentro daquele muro e eu acho que isso aqui vai, é uma parte né, do muro que ficou em mim, pra mim é assim, aí os prédios, esses caras que fazem prédios, fábricas, tão tirando a alegria da favela pra dar abrigo pros "play".

A ameaça da perda da alegria na favela fala de um tempo em transição, um tempo onde o contato, as redes de encontro se produziam como bases do convívio social.

O próprio medo da impessoalidade, que governa a sociedade moderna, prepara as pessoas para verem a comunidade numa escala cada vez mais restrita. Se o eu ficara reduzido a intenções, o compartilhar desse eu fica também reduzido a excluir aqueles que são muito diferentes em termos de classe, de política, ou de estilo. Interesse pela motivação e pelo bairrismo: eis as estruturas de uma cultura construída sobre as crises do passado. Elas organizam a família, a escola, a vizinhança; elas desorganizam a cidade e 0 Estado (Richard Sennett, 1988, p.322)

É assim que Mira pressente que os play ${ }^{15}$ estão ocupando o espaço da alegria, estão cerceando lugares que possibilitavam aos moradores da favela, construir, consumir e compartilhar signos de cidade. "Consumir o signo é integrá-lo ao ventre, ao ser que se é, é digeri-lo em uma exaltação comum, muitas vezes alegre, certamente animada" (Duvignaud, 1983, p.62). Os deslocamentos realizados nos percursos rotineiros, o retraimento dos encontros para esferas restritas de sociabilidade, cerceia a possibilidade

\footnotetext{
${ }^{15}$ Play é uma alusão construída pelos jovens de periferia aos jovens de classe média, aos tradicionalmente denominados burguesia.
}

de uma exaltação comum e alegre dos signos da cidade. A individualização das formas de percepção urbana barra a construção de uma memória sedimentada nas experiências coletivas: "todos os pivetes ali do beco sempre brincaram dentro daquele muro, aí agora não brinca mais, ninguém não pode nem passar para o outro lado”. A produção de lados, de espaços segmentarizados, compartimentados provoca no narrador ondas de nostalgia, de tristeza, de solidão:

A alegria é a liberdade que nós tinha, né, porque ali por perto de casa, ali perto do beco, o único canto que tinha pros pivetes sair pra brincar era aquele campo ali, porque o outro campo que tem na outra rua, não podia ir porque passava carro e lá não, era só pular o muro e você já tava dentro do campo jogando bola e lá foi onde meus dois irmãos aprenderam a jogar bola, pra mim é assim, eu também joguei muita bola dentro desse muro né, que tinha um campo lá, que a gente mesmo fizemos o campo. Acontece muita tristeza na periferia, ao mesmo tempo muita alegria, é a liberdade de você poder brincar e que hoje em dia tão tirando, né, da gente.

A cidade que Mira sente ser comprimida, murada tem como referente à cidade que pode ser percebida, "conhecida pelo tato: corresponde àquela polisensorialidade, cujo estalar de um graveto seco, os ruídos na volta de uma esquina, o odor, agradável ou desagradável correspondem a uma série de associações que, incorporadas, montadas produzem a inteligibilidade da cidade" (Ferrara, 2000, p.84). Essa cidade, conhecida através da experiência sensível, constrói suas teias de memória através das vivências que parecem fundir topografias: corpo e espaço. É desse modo, numa fértil interlocução com Walter Benjamin que Willi Bolle (1994, p.336) destaca a memória afetiva enquanto memória topográfica. A bola, o muro, o jogo em si compõem "lugares, objetos (que) enquanto sinais topográficos, tornam-se vasos recipientes de uma história de percepção, da sensibilidade, da formação de emoções. Os signos-cidade extravasam a leitura dos espaços geográficos, dos mapas imaginários, eles se fincam como marcos afetivos e concretos no lugar-corpo: "essa cicatriz aqui foi uma queda que eu levei dentro daquele muro e eu acho que isso aqui vai, é uma parte né, do muro que ficou em mim”. É nessa perspectiva que podemos pensar, através dos muros que moram em nós, dos becos, das ruas da infância, que a cidade pratica-se através de signos registrados no corpo. Retornemos a função significante do corpo, aludida no tópico 
anterior. "É o fenômeno emotivo que faz viver os códigos. Não basta um sistema de signos para que haja sentido, estes signos precisam de um decodificador" (Gil, 1995, p.217). A cicatriz de Mira e tudo que ela faz emergir na memória da narradora decodifica a vida do bairro dentro daquele muro. Desenha, de forma invisível, um campo sem muros no corpo-significante de Mira.

Essa experiência de praticar cidade, microbiana como bem afirma De Certeau (1994), revela modos de apropriação, de percepção e múltiplas possibilidades de produção de sentidos, revela cidades. Se como afirma, Calvino (1990) a cidade se repete para se fixar na memória, no caso das experiências tácteis, sensoriais; a cidade se multiplica, se metamorfoseia, se expande em cada lugar de vivência. É nesse esteio de configurações acerca dos lados, dos muros, das segmentações que Mira produz a imagem que considera mais significativa da cidade de Fortaleza qual seja, fora do seu bairro. ${ }^{16}$

Mira desenha a avenida Beira-mar, local de intensa afluência dos jovens que moram no Morro Santa Terezinha. O "calçadão" da Beira-mar também congrega vendedores ambulantes, boêmios, prostitutas, turistas, praticantes de cooper e ciclismo, pedintes, skatistas, artesões, dentre outros. A Beira-mar, embora se projete como espaço de múltiplas sociabilidades, de diferentes segmentos de classe, se configura para Mira como outro espaço murado, produtor de apartações:

Essa aqui é a beira mar, quando eu não tenho, ai às vezes quando, por que a maioria das meninas estuda de noite e quando e assim umas sete, oito horas, ai não tem muita gente, tem mais e pouca, ai eu vou lá Pra beira mar, eu fico lá na beira da praia andando ou então na calçada. Às vezes eu vou sozinha, às vezes eu chamo uma piveta pra ir mais eu, que ela gosta de andar de bicicleta ai. Eu me sinto bem lá, eu me sinto bem, assim quando eu to aqui na beira da praia que eu não to escutando zoada, eu fico só no meu pensamento, só a zoada do mar sim, só no meu pensamento mesmo, eu me sinto

\footnotetext{
${ }^{16}$ Vale salientar que foi pedido a cada participante dessa oficina, um desenho ou ma colagem acerca dos lugares mais significativos do seu bairro e da cidade de Fortaleza. Em cada lugar, deveria se desenhar, mostrar como em qual ponto desses cenários situava-se seu corpo.
}

bem, me sinto mais assim eu, me sinto mais eu. Me sinto bem lá na beira da praia, aqui no calçadão não me sinto bem não. Por que lá tem muito play, sei lá.

O calçadão, lugar de intenso fluxo de pedestres, de uma dinâmica de ocupação do espaço ritualizada pelas atividades de lazer, ocasiona em Mira a mesma sensação do lugar-campo de sua infância, hoje, cercado por muros. É como se a paisagem da orla estivesse marcada, apropriada pelos play que parecem erigir limites imaginários para o seu uso. Vale salientar que é na Beira-mar que acontece o Fortal, a micareta, o carnaval murado da Cidade. A Beira-mar é para Mira um espaço de reclusão, de reflexão, lugar só do pensamento. "Se eu tivesse no calçadão eu taria sentada só observando, como os outros jazem comigo. Que o pessoal gosta muito de observar a gente, do jeito que a gente se veste, essas coisas assim". Pular $o$ muro entregar-se aos pensamentos em um lugar que desfila corpos e performances públicas, parece contrariar a tendência assinalada por Sennett:

O comportamento público era um problema de observação passiva, um certo tipo de "voyeurismo". Balzac chamava-o gastronomia dos olhos; a pessoa está aberta para tudo e nada rejeita a prior i de sua esfera de ação, contanto que não tenha que se tornar um participante ou envolver-se numa cena (1988, p.43).

Para Mira, a Beira-mar não se projeta apenas como um outro lugar, particular, de sociabilidade, ela se configura como espaço de vivência de uma outra dimensão de temporalidade, como um outro exercício do olhar; se ver e poder entrever a forma como todos se olham. Para Mira, sair do calçadão, recusar ver e ser vista numa ampliada gastronomia dos olhos, se esboça como prática de fazer cidade nos marcos de uma espacialidade e de uma temporalidade própria, como uma fusão entre carne e pedra (Sennet, 2001).

Quando o lugar é só no meu pensamento, quando nele me sinto mais $e u$, a forma de fruição do tempo no espaço inscreve a lógica do meu pensamento na paisagem. É que "o lugar na cidade está permeado pelo tempo do espaço social que contracena com a cidade como espaço físico" (Ferrara, 2000, p.124). O campo é o tempo do jogo, a Beira-mar é tempo do pensamento e, como veremos a seguir a esquina para Mira é o tempo da amizade/falsidade: 
Do bairro eu botei a esquina, que é o único canto que eu fico mais fora quando eu não venho para cá pro projeto, eu sempre to na esquina, é muito difícil. É desse jeito. Desse jeito mesmo aqui, aqui e os banquinho que fica lá, as calçada onde fica eu e as meninas lá sentada (risos) tesourando, a gente fica conversando não só sobre, porque o pessoal que pensa que se ver um bocado de mulher junta, pronto já ta falando da vida dos outros, mas não só da dos outros, da gente também. Fica mais mulher, às vezes aparece algum amigo da gente, aí senta lá aí começa a conversar, não o Juca, o Israel, os meninos tudinho chega lá pra conversar, tem dia que tem mais homem do mulher, as vezes aí na esquina. A esquina é mais da gente, e daí até uma vez que era altas horas da noite e a gente tava tudo sentada lá e os homens tava botando todo mundo pra dentro, aí teve uma cumade, teve uma cumade que disse assim, da nossa esquina ele não tira a gente não e não tirou não. Os policiais que tem mania de ficar botando os outros pra dentro de casa, não tem o que fazer aí bota. Nós não saímos por que é nosso lugar, é um lugar nosso, o bairro é um lugar nosso, não deles.

As cercas e os muros que circundam os lugares de encontro no bairro e na cidade não são fixos nem visíveis. Eles se projetam a cada momento em que se conspiram e se enraízam apropriações não-oficiais do espaço, apropriações fora dos corredores de adensamento previstos nos planos diretores de ocupação da Cidade. A esquina de Mira projeta-se como um lugar de apropriação particular do espaço público, um lugar de amizade, de falsidade, um lugar de intensidade física.

É melhor que contar a história da esquina, que é tipo assim, lá todo, uma considera a outra, mas é assim: Eu tô sentada aqui conversando com as 'cumade', tamo tudo conversando aqui numa boa, aí por exemplo: uma sai aí fica 'ela aí fez e tal, tal coisa', a história que eu tenho pra contar é essa da esquina. Na esquina existe muita amizade, mas muita falsidade também. Todos se consideram, mas se uma sai assim, aí começa a cortar, a outra sai aí vai começa a cortar, chega as 'cumade' já diz assim, quando vai sair: Ei gente, peraí, deixa eu chegar pelo menos lá na parada de ônibus pra vocês começarem a me cortar. (risos)

No território-esquina, no caso de Mira, um lugar reapropriado pelo gênero feminino, de visitação do masculino, vive-se tessituras do mundo social, com plena expressão dos sentimentos. A esfera pública ganha conotações morais com o desenvolvimento das grandes metrópoles modernas. "O público como um domínio imoral significava coisas um tanto diferentes para homens e mulheres. Para as mulheres, era onde se corria o risco de se perder a virtude, enxovalhar-se (...) o público e a ideia de desgraça estavam intimamente ligados" (Sennett, 1983, p.39). Foi na esquina que os homens tava botando todo mundo pra dentro, como forma de demarcação dos comportamentos de natureza pública e privada, como regulação dos modos de apropriação e de percepção do espaço urbano.

Não é por acaso que Mira se queixa de solidão, que dribla, como Lobão, os limites de padronização de condutas, da criação de uma só nomeação, de percursos costumeiros: "às vezes eu me sinto assim, tá todo mundo sentado, mas eu me sinto sozinha". "O pessoal conversando e pra mim eu to sozinha”. É que os códigos da Cidade, o estar em lugares específicos, provoca nomeações, rotações dos signos urbanos "oficiais". Na esquina ela é Liete, nome de batismo, fora do bairro ela é Mira. Diz ela: "A Mira é mais segura, a Liete não é. Eu acho a Lilá mais segura que a Liete. Talvez porque a Liete é uma pessoa mais na dela, assim, ela é mais agressiva que a Mira”. Mira é a expressão pública de Liete. A Mira é do Enxame, na qualidade de participante de uma Ong, ela já falou várias vezes na televisão e se projeta em outros bairros a partir dessa referência. É Liete que enfrenta "os homê" na esquina do bairro, que sabe que o lugar lhe pertence, que percebe que embora os muros se ergam os campos ali cerceados sobrevivem nas fendas do corpo. A Liete, assim como Chuchu é "indisciplinada, agressiva, foge de todas as regras". Porém, indagada o que fazer com a Liete, ela responde: "Queria conviver com ela nas horas que fosse preciso, porque se ela um dia morrer, eu vou precisar dela, por isso eu não quero que ela morra". A cidade não morre na dinâmica dos códigos de Chuchu e Liete.

$\mathrm{Na}$ fala de Mira, a cidade aparece como um todo "no qual nenhum desejo é desperdiçado e do qual você faz parte, e, uma vez que aqui tudo se goza, tudo que não se goza em outros lugares, não resta nada além de residir nesse desejo e satisfazer" (Calvino, 1990, p.16). Todos os interditos, muros, policiais, olhares devoradores da orla produzem em Mira vontade de estabelecer "linhas de fuga" (Deleuze, 1997), formas múltiplas de percepção e apropriação do espaço urbano. Desse modo, essas linguagens pontilhadas de signos (muro/esquina/orla) esboçadas por Mira, projetam novas cadeias 
semióticas. Tendo em vista que "a cadeia semiótica é um tubérculo que aglomera atos muito diversos, linguísticos, mas também perceptivos, mímicas, gestuais, cognitivos: não existe língua em si, nem universalidade de linguagem, mas um concurso de dialetos, de patoás, de gírias, de línguas especiais" (Deleuze, 1995, p.16). Não seria a Cidade de Mira uma combinação de estratégias e táticas (De Certeau, 1994) capazes de potencializar um uso delinquente da Cidade? Delinquente por saber dos sentidos diversos que fazem-cidade, por saber que os usos desvelam-se quando não resta nada além de residir nesse desejo e satisfazer? De que a cidade, seus muros, seus cercos policiais, suas passarelas são para serem re-inventadas, para serem vividos de acordo com os lugares de memória habitados no significante corpo? Se nada escapa ao corpo, se ele mora em cada lugar que fala cidade, Mira tem razão, o bairro é um lugar nosso e não deles.

\section{Referências}

Augé, M. (1994). Não lugares - Introdução a uma antropologia da supermodernidade. Campinas, SP: Papirus.

Bachelard, G. (1998). A poética do espaço. São Paulo: Martins Fontes.

Benjamin, W. (1975). A modernidade e os modernos. Rio de Janeiro: Tempo Brasileiro.

Bolle, W. (1994). Fisiognomia da metrópole moderna. São Paulo: Edusp.

Calvino, I. (1991). As cidades invisíveis. São Paulo: Companhia das Letras.

Canevacci, M. (1993). A cidade polifônica - ensaio sobre a antropologia da comunicação urbana. São Paulo: Studio Nobel.

Canevacci, M. (2001). Antropologia da comunicação visual. Rio de Janeiro: DP\&A.

Deleuze. G. \& Guatarri, F. (1995). Mil Platôs - Capitalismo e esquizofrenia (v. 1). São Paulo: Ed. 34.

Deleuze, G. \& Guatarri, F. (1997). Mil Platôs - Capitalismo e esquizofrenia (v. 5). São Paulo: Ed. 34.

De Certeau, M. et alii. (1994). A invenção do cotidiano - Artes de fazer, ( $2^{\mathrm{a}}$ ed.). Rio de Janeiro: Vozes.
De Certeau, M. et alii (1995). A cultura no plural. São Paulo: Papirus.

Diógenes, G. (1998). Cartografias da cultura e da violência - Gangues, galeras e o movimento hip hop. São Paulo: Annablume; Fortaleza: Secretaria da Cultura e do Desporto.

Duvignaud, J. (1983). Festas e civilizações. Fortaleza: Edições Universidade Federal do Ceará; Rio de Janeiro: Tempo Brasileiro.

Ferrara. L. D’A. (1993). Olhar periférico. São Paulo: Editora da Universidade de São Paulo.

Ferrara, L. D’A. (2000). Os significados urbanos. São Paulo: Edusp.

Gil, J. (1995). Corpo. In Enciclopédia - Soma/psique-corpo (v. 32). Lisboa: Imprensa Nacional.

Herschmann, M. (2000). O funk e o hip hop invadem a cena. Rio de Janeiro: Editora UFRJ.

Hillmann, J. (1993). Cidade \& alma. São Paulo: Studio Nobel.

Morin, E. (1990). Cultura de Massas no Século XX - Neurose. ( $8^{\mathrm{a}}$ ed.). Rio de Janeiro: Forense Universitária.

Sennett, R. (2001). Carne e pedra. O corpo e a cidade na civilização ocidental. São Paulo: Record.

Sennett, R. (1988). O declínio do homem público - As tiranias das intimidades. São Paulo: Companhia das Letras.

Silva, A. (2001). Imaginários urbanos. São Paulo: Perspectiva. 


\section{Combates urbanos: a cidade como território de criação}

Luis Antônio Baptista

Ele [o fascismo] vê sua salvação no fato de permitir às massas a expressão de sua natureza, mas certamente não a dos seus direitos. (...) $\mathrm{Na}$ época de Homero, a humanidade oferecia-se em espetáculo aos deuses olímpicos; agora, ela se transforma em espetáculo para si mesma. Sua autoalienação atingiu o ponto que lhe permite viver sua própria destruição como um prazer estético de primeira ordem. Eis a estetização da política, como a prática o fascismo. $O$ comunismo responde com a politização da arte.

(Walter Benjamim. A obra de arte na era de sua reprodutibilidade técnica)

A identidade alemã foi confeccionada como obra de arte: formas espetaculares desenharam o espírito da massa nos estádios esportivos, nas marchas militares, em canções patrióticas. A estética nazista indicou quem eram os alemães, o que deveriam ser, mas vetou a transfiguração da alma ariana. $\mathrm{O}$ povo vislumbrava o rosto coletivo, reconhecia-se nele, consumia-o, impossibilitado de violar a essência alemã, conspirar um outro destino. Arte e política fizeram a diferença brilhar, mas impediram-na de recusar a estética da sua irremediável natureza. Alemão só deveria beber cerveja alemã.

O que a estetização da política apontada por Walter Benjamim tem a nos dizer sobre a criatividade do capitalismo contemporâneo? Pode a cidade ser definida como zona de guerra, ${ }^{1}$ onde a vida se faça aliada? Salvam as cidades as coisas da sua crescente miséria? Mas qual miséria?

${ }^{1}$ Segundo James Holston: "Essa zona de guerra contemporânea compreende não só o terro dos esquadrões da morte e das gangues, mas também o terror das fortalezas corporativas e dos enclaves suburbanos. Os últimos são também formas insurgentes do social, subvertendo as proclamadas igualdades e princípios universais da cidadania nacional. (...) Tanto quanto o otimismo pode ser irradiado pelos movimentos sociais da cidade, essa ansiedade paira sobre sua zona de guerra, estruturando seus possíveis futuros" (Espaços de cidadania
A criatividade invade a cidade em mais um ato de indignação contra a insegurança. Na manhã chuvosa do Rio de Janeiro, a passeata atravessa a Avenida Vieira Souto clamando por paz. Homens, mulheres, crianças, políticos, representantes dos movimentos sociais, misturados aos atores da novela das oito, suplicam por uma cidade desarmada. Entre o mar e os prédios gradeados, a passeata criativa enuncia palavras de ordem nas músicas, nas coreografias das alas, desejando um mundo pacífico e seguro. Os rostos desta multidão procuram pelas câmaras, posam emocionados para as máquinas fotográficas, ansiosos em reconhecer, nas futuras imagens da mídia, dores coloridas, emoções familiares, em mais um espetáculo urbano onde tudo fenece rapidamente. Contudo, na manifestação pública, agruras singulares diferenciam-se tanto das que são representadas pelos atores da novela quanto das expressadas pelos manifestantes temerosos das balas perdidas. Nesta passeata do espetáculo, homens e mulheres exibindo cartazes com nomes e fotos de seus mortos, assassinados pela violência do Estado, desprezam as câmaras, ignoram o trajeto rumo a TV, portando cicatrizes que nenhum espetáculo urbano consegue dissipar. São cicatrizes narradoras de sofrimentos não privatizados, marcas da história do nosso país entrelaçada a outros lugares, apresentando a força da memória como arma combativa, em momentos de perigo que nos enfraquecem como protagonistas do nosso tempo. Essas marcas narradoras de histórias inacabadas sujam as imagens da multidão asséptica, que suplica por serenidade em seus condomínios gradeados, como se a cidade inexistisse. Quando as cicatrizes perdem o risco de macular a paisagem, inspiram compaixão e lágrimas efusivas, que logo se esvaem como um banal acontecimento neutralizado pelo excesso de emoções.

As cicatrizes com cheiro e textura dos parentes das vítimas da violência do Estado contrastam com a criatividade das ilhas de produção cinematográfica, editando aceleradamente o tempo dos acontecimentos a fenecer antes de finalizar o que tem a nos dizer. Atravessando a Avenida Vieira Souto, imagens coloridas, emocionadas, passam rapidamente sobre as calçadas, apresentando-nos mais um espetáculo a ser consumido durante o jantar. À noite, esta cena urbana é exibida aos pedaços, entre o comercial

insurgente. In Arantes, A. (Org). Revista do Patrimônio Histórico e Artístico Nacional, Rio de Janeiro, 24, 1996). 
do cartão de crédito e do sabão em pó, sugerindo ao cidadão-telespectador digerir mais um sedutor esquecimento. Durante o jantar, grãos de luzes em movimento na tela desmaterializam a memória, negando-a corpo ou fúria. Podem as cidades salvar as coisas de sua crescente miséria?

$\mathrm{Na}$ zona sul carioca, no bairro de Laranjeiras, jovens guerreiros correm pelas ruas. São militares do Batalhão de Operação Especiais, exercitando os músculos e o espírito da corporação. O exercício aeróbico é realizado todas as manhãs, de forma criativa, moderna, diferente do uso das tradicionais palavras de ordem usadas por velhos militares enaltecendo a pátria e o vigor dos soldados. Percorrem as ruas do bairro em movimentos cadenciados, utilizando o rap como inspiração. Na ginástica matinal para o fortalecimento dos músculos, do espírito coeso do grupo, cantam com a voz viril, guerreira, o ritmo nascido nas periferias urbanas. Correndo pelas calçadas com garbo e disciplina, jovens militares entoam os seguintes versos:

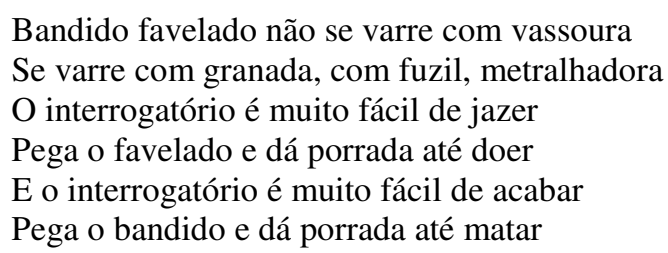

Vozes másculas, ritmadas, exibem para o Rio de Janeiro a força militar solicitada pela população que exige segurança paz. Jovens guerreiros apresentam-nos todas as manhãs o espetáculo musical, indicando-nos as origens das mazelas urbanas e o modo de combatê-las. Nesta música, vozes civis de donas de casa, aposentados, profissionais liberais, parlamentares participam de vários cantos estranhos à caserna, compondo o coro uníssono capaz, segundo eles, de enfrentar as sombras da cidade. Para esse coro polifônico, os males que ameaçam o Rio de Janeiro congelado em cartão-postal devem ser extirpados pela raiz. A cidade invisível dos caminhos inusitados, das bifurcações, encruzilhadas, que descongela o pensamento sugerindo-o a escapar de verdades criadas pelo medo e pela força, é ofuscada pela estética bélica da segurança pública. Pode a criação gerada dos territórios urbanos salvar as coisas da sua crescente miséria? Mas qual miséria?

A mulher negra de quarenta e poucos anos acorda assustada, procurando o cobertor. Olha para o lado e não encontra a caixa de papelão com seus pertences. Desesperada, constata pessoas estranhas pressionandoa para entrar no carro. Ela, atônita, não entende a inusitada situação. São seis horas da manhã na calçada da rua Visconde de Pirajá, em Ipanema. A moradora de Mesquita, na Baixada Fluminense, vendedora de balas no sinal de trânsito, que dorme na rua para economizar o dinheiro da passagem, desperta do sono, assustada, e descobre o desaparecimento dos seus objetos. Na caixa de papelão guardava caneca, carteira de identidade, roupas íntimas, batom, oração de São Jorge, o endereço da comadre, casaco para a chuva, fotos dos filhos vivos e mortos embrulhadas no papel do pão. A funcionária da prefeitura, com voz doce, informa que uma vida melhor a espera. O rapaz de voz firme confirma a informação, e lhe diz que não precisa mais da caixa; no abrigo, terá roupa lavada, cama, alimentos, e a proteção da prefeitura. A operação "Cata Tralha" limpa as calçadas do Rio de Janeiro, retirando das suas ruas qualquer impureza que possa sujar a paisagem urbana. Consternada, a vendedora de balas constata que a caixa de papelão com objetos da sua história foi para o depósito municipal. Os seus pertences, contando coisas dela entrelaçadas a muitas outras, viraram mais uma tralha incômoda à cidade.

A mulher chega à triagem da Secretaria de Desenvolvimento Social do Município ainda assustada, e descobre que o que lhe foi prometido inexiste. Toma banho, segue com a mesma roupa, é submetida a uma série de entrevistas, e à noite levam-na a dormir junto aos outros moradores das ruas. Ao seu lado, o homem com tuberculose reclama do desaparecimento do seu cachorro. No quarto abafado, dormem crianças, adolescentes, homens sem carteira de identidade, sem cachorro, sem oração de São Jorge, sem endereço da comadre, sem fotografias dos filhos vivos e mortos, à espera da vaga nos abrigos. Pela manhã, ela é dispensada e retorna sem nada à rua. A operação "Cata Tralha" lhe recomenda não se fixar no mesmo posto. Tralhas humanas ou inumanas são proibidas de parar; devem se deslocar, circular pela cidade como imagens em aceleração, para não interferir na paisagem congelada em cartão-postal. Desmaterializados, mudos, despossuídos dos objetos da memória, recomeçam a nova vida circulando atados ao presente eterno que lhes oferta somente a sobrevivência. $\mathrm{O}$ ontem e o amanhã destas tralhas humanas ocupam o

\footnotetext{
${ }^{2}$ Nome utilizado pelos técnicos da Secretaria Municipal de Desenvolvimento Social
} 
depósito municipal. O tempo virou lixo; a história deles, e a da cidade invisível provocando o pensamento a se desacomodar, contagiado pelas minúsculas astúcias do cotidiano, também.

No Rio de Janeiro do final dos oitocentos, vagabundos, loucos, criminosos, miseráveis, eram retirados do espaço público e alocados nos devidos lugares para a correção dos males entranhados em suas almas. Essas criaturas "perigosas" necessitavam da força da lei e da ciência para a higienização do espaço urbano. Nas cidades do mundo do espetáculo do capitalismo fluido, leve, onde tudo fenece rapidamente, os abrigos são inoperantes. Nesses lugares, estrategicamente precários devido à lipoaspiração do Estado enxugando gastos, a lógica contemporânea do capital não os retém, e sim os expele, ou os acolhe provisoriamente, antes de mais uma incessante circulação. Somente nas delegacias, presídios, campos de concentração, depósitos municipais, desprovidos de qualquer sonho regenerador, tralhas humanas se amontoam cada vez mais, para que a cidade tenha segurança e serenidade. Podem as cidades salvar as coisas da sua crescente miséria? A cidade como território de criação combate o quê? Qual criação? Qual combate?

A vendedora de balas, moradora de Mesquita, entra nas Casas Bahia e pede uma caixa de papelão. A vizinha lhe dá o cobertor puído, usado para passar roupa. Na igreja ela ganha uma outra oração de São Jorge. Da venda das balas, compra o batom. A irmã descobre uma foto antiga do sobrinho assassinado pela polícia. Pouco a pouco, a caixa de papelão é ocupada por novos objetos. Ela repete tudo de novo para não ser destruída mais uma vez. Na caixa, um mundo em frangalhos, puído, é recriado por experiências usadas, recompondo em inesgotáveis sentidos crônicas do cotidiano supostamente exauridas. Ela enfrenta o tempo asséptico, utilizando como arma a fúria da memória.

Na passeata de Ipanema, manifestantes desatentos às câmaras da TV repetem há muitos anos o nome de seus familiares assassinados pelo Estado. Mulheres argentinas, mexicanas, palestinas, também insistem em repetir palavras de ordem no espaço público, desprivatizando suas dores, tornando-as civis, recusando o fardo da autoria. Essa gente anônima se apropria da cidade como zona de guerra. Ao contrário da concepção dos guerreiros do rap, fundada no medo e no genocídio, esta guerra tem a vida como aliada. A cidade como zona de guerra é a ferramenta utilizada para o embate à crescente miséria produzida pelo capitalismo contemporâneo. Essa miséria se materializa no desencanto paralisante decretando o esgotamento de experiências que ficaram na metade do caminho, na espreita de parcerias contemporâneas em momentos de perigo; essa miséria se concretiza na impossibilidade de recusarmos aquilo que nos define para todo o sempre e sufoca a força criativa da revolta privatizando-a, tornandoa tola, ressentida. Para o desencanto celebrado pelo capitalismo contemporâneo, só nos restam carências intermináveis, nunca saciadas no mundo sedutor, criativo, empurrando-nos para a ávida procura do novo que fenece rapidamente antes de afirmar a força da sua presença. É o mundo da política convertido em estética, do fomento à criatividade que não leva a lugar nenhum, a não ser ao vazio e voraz individualismo fincado na incerteza. Da miséria ganhamos o desprezo ou a indiferença a tudo que ultrapasse os territórios gradeados fixando-nos na falta. Da falta ganhamos apenas o irremediável destino de um eu solitário em permanente desmanche.

Nas cidades usadas como zona de guerra, nada está concluído ou perdido definitivamente. A paz não é bem vinda, porque a alteridade, em sua radicalidade tensa, desacomoda, perturba, à semelhança da politização da arte criadora de intensidades inesgotáveis de sentidos, diluindo compactas e irrefutáveis formas de eu e nós. Nas cidades como campo de combate, podemos fazer da insurgência um ato criativo, à semelhança da teimosa caixa de papelão das Casas Bahia, prenhe de artes da existência contando histórias intermináveis. Nessas cidades, a vida não nos dá sossego. Nada está em paz, concluído, definitivamente perdido. No desassossego, virtualidades de resistências podem enfrentar o mórbido desencanto. 


\section{SIMPÓSIO 6 - VIOLÊNCIA E DIREITOS HUMANOS: ADOLESCENTES EM CONFLITO COM A LEI}

\section{A FEBEM e suas propostas socioeducativas baseadas na "Tropa de Choque" e no "Choquinho"}

\section{Rosalina Carvalho da Silva}

Ninguém será submetido à tortura, nem a tratamentos ou punições cruéis, desumanas ou degradantes.

Inicio este texto trazendo trechos extraídos de um recente Relatório sobre fatos que ocorreram em uma Unidade de Internação para jovens que entram em conflito com a lei. Lembrando que são inúmeros os relatórios de órgãos nacionais e internacionais que trazem as mais graves denúncias de violação de direitos.

Os trechos destacados aqui fazem parte do Relatório sobre as intervenções ocorridas nas unidades da FEBEM de Ribeirão Preto em julho e agosto de 2003.

Em face da notícia de espancamentos ocorridos nas unidades locais da FEBEM (Fundação para o Bem Estar do Menor do estado de SP) diante do que fora constatado nas primeiras visitas no local, formou-se Comissão Interinstitucional. ${ }^{2} \mathrm{O}$ Ministério Público, pelo promotor de justiça da infância e juventude, instaurou o inquérito civil $n^{\circ} 433 / 2003$ para a apuração dos fatos. Membros da Comissão acompanharam as

\footnotetext{
${ }^{1}$ Artigo V da Declaração Universal dos Direitos Humanos de 10 de dezembro de 1948.

${ }^{2}$ Promotoria de Justiça da Infância e da Juventude; Ordem dos Advogados do Brasil Subsecção de Ribeirão Preto; Conselho Municipal de Direitos da Criança e do Adolescente de Ribeirão Preto; Conselhos Tutelares I, II e III de Ribeirão Preto; Comissão de Direitos Humanos da Câmara Municipal de Vereadores de Ribeirão Preto; Conselho Regional de Psicologia; Conselho Regional de Serviço Social; Conselho Regional de Enfermagem; Pastoral do Menor; CEDHEP — Centro de Direitos Humanos e Educação Popular; ADUSP - Associação dos Docentes da Universidade de São Paulo (USP); Associação Ecológica Pau Brasil; Cindedi (USP)
}

investigações. Provas orais, periciais e documentais foram produzidas. $\mathrm{O}$ inquérito foi concluído.

Destaco partes desse relatório que pode ser encontrado em sua íntegra no site do Grupo de trabalho pelo Fechamento da FEBEM $^{3}$.

Em 30 de julho de 2003, os adolescentes em cumprimento de medida sócio-educativa de internação ocupavam os Pavilhões 3,6 e 7 da Unidade de Internação Ribeirão (...) tentaram fugir através do telhado. Frustrada a fuga e após negociações com funcionários (...) da Unidade, os adolescentes retornaram para as alas dos quartos dos respectivos pavilhões (...) A Tropa de Choque da Polícia Militar foi acionada pelo então diretor, chegou à Unidade por volta das $7 \mathrm{~h} 00$ (...) Por volta das 8h30, a Presidência da FEBEM e a Secretaria de Estado da Segurança Pública autorizaram a entrada da Tropa de Choque nos Pavilhões. Objetivo: apoiar a ação dos funcionários na contagem dos adolescentes, revista interna, verificação de danos ao patrimônio e redistribuição dos adolescentes nos Pavilhões. A ação foi acompanhada por funcionários da FEBEM, pelo Juiz da Infância e da Juventude e por dois Comandantes da Polícia Militar (de Área e do Batalhão) (...) No Pavilhão 6, os funcionários tomaram a frente e, na ala dos quartos, ao iniciarem a comunicação, aos adolescentes, do que ocorreria, a Tropa de Choque já começou a intervir. O funcionários, então, deixaram o local. Os policiais militares, acompanhados de cães e aos gritos, acordaram os adolescentes que ainda estavam a dormir e determinaram que todos "descascassem", ou seja, tirassem a roupa, e ficassem apenas de cueca ("coruja", no linguajar dos adolescentes). Atendendo às determinações dos policiais militares, os adolescentes formaram fila, colocaram as mãos para trás do corpo e baixaram a cabeça. Assim formados, foram encaminhados para a ala do pátio. No trajeto percorrido entre a ala dos quartos e o pátio, especialmente no trecho da escada, os adolescentes passaram por uma espécie de corredor formado pelos policiais militares, que os agrediram com tapas, socos, pontapés e golpes desferidos com cassetetes. Alguns policiais militare deixaram os cães saltarem na direção dos adolescentes, como se fossem mordê-los, puxando, em seguida, os animais pela guia, antes que a mordida se consumasse (...) encaminhados para o Pavilhão 4

\footnotetext{
http://www.geocities.com/fecharfebem
} 
(...) ao subirem a escada que liga o pátio à ala dos quartos, os adolescentes passaram por um "corredor polonês" formado por policiais militares e, ali, foram agredidos com "borrachadas".

Noutros pavilhões seguiram-se os mesmos tratamentos:

(...) No pátio, os adolescentes (só de cuecas) foram obrigados a sentar no chão, de cabeça baixa e mãos sob as nádegas, virados para a parede e de costas para uma fila de policiais militares com cães. Os cães pulavam e latiam muito e os policiais também produziam muito barulho, para pressionar psicologicamente os adolescentes (...) Sob o comando desnecessariamente agressivo dos policiais, cada adolescente, ao pegar a muda de roupa, dirigia-se à área contígua à parede oposta da qual provinha, tirava a cueca e, completamente nu, "pagava canguru" (fazia flexões, agachando com as mãos postas sobre a nuca) (...)

As ações da tropa de choque estenderam-se por outros pavilhões. É necessário ressaltar que a motivação para a fuga estava relacionada com um clima de tensão existente na unidade desde o início de 2003, pela falta de estrutura para o atendimento e ausência de programa pedagógico e de atividades sócio-educativas adequadas. Os jovens reclamavam também da falta de critérios claros para a progressão da medida sócio-educativa e para a liberação. Vale lembrar que, há algum tempo, a FEBEM de Ribeirão Preto dispunha de trabalhos universitários de extensão e a comunicação dos jovens com o Juiz da Infância e Adolescência se dava de maneira mais clara. Os jovens sabiam o que os esperava em termos de progressão nas medidas. Não que se possa dizer que em algum momento alguma unidade de internação da FEBEM tenha oferecido tratamento e proposta socioeducativa adequada como prevê o Estatuto da Criança e do Adolescente ECA (Brasil, 1990).

\section{O “choquinho” e as medidas de humilhação dos jovens internos}

Enquanto a polícia militar com sua tropa de choque entra na instituição para supostas revistas, a instituição forma entre seus quadros de funcionários o famoso "choquinho". Ressalte-se que alguns desses funcionários, contratados teoricamente como monitores ou educadores, recebem trajes e instrumentos semelhantes aos da tropa de choque da polícia militar para "colocar ordem na casa". Algumas destas ações estão destacadas nos trechos a seguir, ainda segundo o mesmo relatório.

Na manhã de 7 de agosto de 2003, alguns adolescentes, em clima de tensão por descontentamento com os tratamentos empregados pela instituição, recusaram-se a entrar em sala de aula e depois do almoço, alguns deles jogaram pedaços de carteiras escolares e pedras por cima de uma muralha. $\mathrm{O}$ diretor chamou um grupo de funcionários estranhos àquela Unidade, conhecido como "Grupo de Intervenção" ou "Choquinho", para que procedessem à intervenção. Grupo integrado por funcionários de outras unidades do Estado de São Paulo. Esses funcionários...

munidos com pedaços de pau e gritando muito alto, entraram no Módulo 2, correndo atrás dos adolescentes e os espancando. Após a primeira sessão de espancamento e sob o comando dos funcionários, os adolescentes ficaram nus. Trajando apenas cueca, sentaram no chão do pátio, "encaixados"'(um atrás do outro, presos pelas pernas), com as cabeças baixas e as mãos sobre as nucas. Os funcionários agrediram, com safanões, os adolescentes que não suportavam ficar por muito tempo com a cabeça baixa, utilizando a seguinte expressão: "Ei vagabundo! Abaixa essa cabeça, ladrão!” (...) Alguns adolescentes foram "destacados" do grupo que estava sentado no pátio e levados para trás o prédio onde se situam os quartos. Ali, os funcionários desferiram tapas, socos, pontapés e pauladas nos adolescentes.

Funcionários daquela Unidade colaboraram com o "Grupo de Intervenção", agredindo física e verbalmente os adolescentes, dentre eles, o diretor. Ainda segundo o relatório:

(...) Durante horas, os adolescentes do Módulo 2 foram submetidos a tratamento violento, desumano, vexatório, aterrorizante e constrangedor. Os funcionários cortaram os cabelos de todos os adolescentes, deixando-os com as cabeças raspadas. Como se as agressões físicas não fossem o bastante, os funcionários humilharam e ofenderam verbalmente os adolescentes. Os funcionários (...) protagonizaram as piores cenas de terror e humilhação. Por ordem deles, os adolescentes foram obrigados a dizer que eram "suínos" e "tangas soltas e atoladas" (expressão utilizada no sentido de homossexual) e que "amavam os funça" (corruptela da palavra funcionário) (...) o "Boca de Lata", dirigiu-se aos adolescentes, em voz alta, usando as seguintes palavras: "Vocês estão tomados pelo 
demônio e agora vocês encontraram Deus! Vocês serão libertos pelo "Exu Caibrada'. Aleluia!" (...) Um dos adolescentes chegou a vomitar e foi obrigado a sentar e a esfregar-se sobre o vômito. Outro adolescente urinou e foi obrigado a ficar de pé, expondo-se aos funcionários e aos demais adolescentes, com a cueca e as pernas molhadas. A agravar o tratamento vexatório, essa vítima teve de ouvir a seguinte manifestação de um dos funcionários: "Olha! Ele mijou na cueca". Outros, ainda, ao serem chamados para o corte de cabelo, levantaram-se do chão e se apresentaram com o pênis ereto. Os funcionários do "Grupo de Intervenção" dirigiram-se a eles usando a seguinte expressão: "Oh! Mocinha... fica de pé para todo mundo ver. Só porque você estava encostado nele ficou de pau duro!". Um adolescente negro foi agredido verbalmente por funcionário que usou a seguinte expressão: "Neguinho tem esse bico de tanto fumar maconha".

A intervenção no Módulo 2 terminou por volta das 22 horas. Em outros módulos, as intervenções além da ocorrência dos espancamentos os jovens foram, mediante socos, tapas, joelhadas e pontapés, obrigados a simular a brincadeira de "ciranda-cirandinha", enquanto eram chamados de "mariquinhas", e foram ainda forçados a imitar galinha e a desfilar e correr nus. Um dos funcionários passou um cabo de vassoura nas costas dos adolescentes, do pescoço até as nádegas.

O Relatório na íntegra, disponível no site citado anteriormente, traz os detalhes e nomes de todos os funcionários envolvidos, que se diga não eram só monitores, mas também integrantes de equipes técnicas. O relatório registra ainda a presença de um psicólogo, encarregado técnico de uma das unidades de internação, no acompanhamento dessas sessões.

A Comissão concluiu depois de analisar todos os fatos que o Governo do Estado de São Paulo, por intermédio de policiais militares, e a FEBEM, por intermédio dos seus funcionários, não observaram os direitos e garantias dos internos, violando o direito fundamental ao respeito e à dignidade em condutas que tipificam o crime de tortura, uma vez que os adolescentes que ali cumpriam medida socioeducativa de internação foram submetidos a intenso sofrimento físico e mental, com emprego de violência e grave ameaça. Com isto, o Ministério Público ajuizou ação civil pública, postulando a condenação do Governo do Estado de São Paulo e da FEBEM no pagamento de indenização por danos morais difusos, a ser recolhida ao fundo gerido pelo Conselho Municipal dos Direitos da Criança e do Adolescente de Ribeirão Preto. Os inúmeros casos apurados.

Os acontecimentos relatados fazem parte apenas de uma pequena amostra das violações de direitos de jovens pobres, que entram em conflito com a lei, em nosso país. Inúmeros relatórios, elaborados por organismos nacionais e internacionais, mostram também compilações de violações dos direitos existentes em nosso país. O mais recente deles elaborado por Asma Jahangir é relativo à sua recente missão no Brasil, que ocorreu entre 16 de setembro e 8 de outubro de 2003. Ela percorreu os Estados da Bahia, Pernambuco, Pará, Rio de Janeiro, Espírito Santo e São Paulo e Distrito Federal. Em São Paulo, a representante da ONU foi impedida de visitar e entrevistar jovens internados nas unidades da FEBEM da capital. Esse relatório, que inclui diversas provas de graves violações aos direitos humanos no país, será apresentado à Comissão de Direitos Humanos da ONU, que se reúne em março e abril de 2004 em Genebra.

O recente Mapeamento Nacional da Situação do Atendimento dos Adolescentes em Cumprimento de Medidas socioeducativas (IPEA; DCASEDH e UNICEF, 2003) verificou que, com relação às unidades, embora se registrem alguns progressos, com a construção de unidades mais compatíveis com o que se espera pelo ECA, e, em alguns estados já venha ocorrendo a descentralização das mesmas, ainda ocorrem inúmeros problemas, como instituições ainda concebidas nos padrões do antigo Sistema FEBEM, tais como: superlotação, maus tratos, tortura e falta de capacitação dos recursos humanos. Existem ainda casos extremos de violência em diversas unidades, culminando com rebeliões e mortes de adolescentes.

Um outro documento, o relatório de compilações das denúncias de violação de direitos nas unidades de internação de adolescentes em conflito com a lei (IPEA; DCA-SEDH e MNMMR, 2003) mostra que em todo Brasil são inúmeros os relatos de graves denúncias. Grande parte delas foram comprovadas materialmente por laudos de exames de corpo delito, por testemunhos, arquivos de fotos e fitas de vídeo. Em resumo, são muitos os documentos produzidos, por diversas fontes idôneas sobre as violações dos direitos humanos da população jovem de nosso país, principalmente os que entram ou são suspeitos de entrar em conflito com a lei. 
Com tudo que se difunde sobre esses documentos sobre as graves denúncias de violações de direitos dos jovens, principalmente os que se encontram privados de liberdade, não seria de se esperar que mais setores da população brasileira, do que aqueles que cobram mudanças, viessem também a cobrá-las das autoridades competentes? Por que isto não ocorre? A quase inexistência de reação por parte da população pode ter inúmeras motivações baseadas em diferentes impressões ou em diferentes ideários. Impressões entendidas aqui como noções ou opiniões vagas, sem grandes fundamentos ou como modos de apreender os fatos em que prevalecem as sensações ou as emoções em detrimento das abordagens com bases mais racionais ou reflexivas. E, ideários compreendidos como conjuntos das ideias pertencentes a determinados tipos de doutrinas ou conjunto de aspirações de grupos sociais.

Dentre as impressões que podem estar contribuindo para que não haja uma indignação social que resulte em cobranças mais efetivas para as mudanças nos modos como são tratados os jovens, que entram em conflito com a lei, pode estar a ideia de que o problema seja de tal magnitude que nada, ou muito pouco, pode ser feito. E, isto pode estar ocorrendo porque se pensa que o número de jovens privados de liberdade seja enorme e que estes sejam extremamente perigosos e que, portanto não haveria proposta sócio-educativa que pudesse dar conta da reintegração social dessa população. Mas, é necessário levar em conta também que por trás dessa insuficiente indignação podem estar os ideários ligados ao antigo código de menores e todos os preconceitos existentes ao longo da história do Brasil a respeito da infância e juventude das camadas populares.

A ideia de que nada pode ser feito: as impressões ou mitos que nos imobilizam

O papel dos meios de comunicação na criação e manutenção de imagens muito negativas em relação aos jovens infratores é sem dúvida muito importante. A esse respeito pode se ver o estudo de Njaine e Minayo (2002) intitulado "Análise do discurso da imprensa sobre rebeliões de jovens infratores em regime de privação de liberdade". Nesse estudo, realizado em relação às unidades de internação do estado do Rio de Janeiro, as autoras apontam para o papel da mídia no fortalecimento da visão negativa e incriminadora dos jovens, que pode contribuir com ações mais violentas contra esse grupo. Muito raramente revela as questões sociais, institucionais e de inadequação pedagógica que permeiam tais eventos (p.286).

A ANDI (Agência de Notícias dos Direitos da Infância) tem contribuído para a discussão dessa questão com a realização de pesquisas que têm apontado para os grandes problemas existentes na mídia na veiculação de versões negativas sobre a infância e adolescência marginalizadas. Os resultados e sugestões desses estudos têm sugerido importantes maneiras para correção desse rumo.

Segundo a ANDI (2002), entre os fatores que contribuem para pensarmos que não há o que fazer com essa população estão: o mito da impunidade que seria dada pelo Estatuto da Criança e Adolescente (ECA) ao jovem que entra em conflito com a lei; o hiperdimensionamento dessa população e o hiperdimensionamento da periculosidade dos atos infracionais dessa população.

É importante ressaltar que os meios de comunicação assim como têm contribuído para a construção de imagens, exacerbadamente negativas, também têm contribuído, ainda de maneira não totalmente adequada, para que se possa construir versões diferentes. Não podemos deixar de levar em conta que a mídia reflete os anseios da população no que diz respeito às possíveis apurações e explicações das causas das violências que tanto nos mobiliza emocionalmente.

\section{Os jovens em conflito com a lei ficam impunes?}

O mito da impunidade do jovem surge, sobretudo por conta da insuficiência de informação para o grande público, e até mesmo para algumas formações em nível universitário, sobre o sistema socioeducativo previsto pelo ECA. A impunidade é confundida com inimputabilidade dando a ideia errônea de que os jovens ficam impunes ou não são responsabilizados pelos seus atos. A visão de impunidade do jovem decorre de uma interpretação equivocada do ECA e do desconhecimento do que se passa no cotidiano. 
Inimputabilidade, todavia, não implica impunidade, uma vez que no ECA se estabelece medidas de responsabilização compatíveis com a fase peculiar de desenvolvimento em que se encontram os adolescentes. Isto quer dizer que não existe irresponsabilidade pessoal ou social (Volpi. 1997). O ECA sanciona medidas socioeducativas e medidas de proteção e reconhece a possibilidade de privação provisória de liberdade ao infrator, inclusive em caráter cautelar ao adolescente não sentenciado. Seguindo para isto, parâmetros semelhantes aos do Código de Processo Penal e oferece uma gama larga de alternativas de responsabilização, cuja mais grave impõe o internamento sem atividades externas.

O sistema socioeducativo proposto pelo ECA comporta um amplo conjunto de recursos para dar conta das questões relativas à criminalidade na juventude. As ações previstas se resumem, segundo o artigo 112 do ECA, nas seguintes: I. advertência; II. obrigação de reparar o dano; III. prestação de serviços à comunidade; IV. liberdade assistida; V. inserção em regime de semiliberdade; e VI. internação em estabelecimento educacional.

A medida de privação de liberdade, provisória ou por flagrante, exige que se julgue gravidade do ato infracional e sua repercussão social, para garantia da segurança do adolescente ou para manutenção da ordem pública, segundo o artigo 174 do ECA. O Estatuto prevê também, como a Constituição Federal todas as garantias processuais que são previstas para todo cidadão. Assim, o adolescente tem direito à identificação dos responsáveis pela sua apreensão, bem como deve ser informado dos seus direitos, que, no ato da apreensão, consistem em assegurar-lhe a assistência da família e do advogado. Em suma a legislação brasileira assegura ao adolescente os mesmos direitos dos imputáveis, inclusive o processo legal.

Entretanto, as práticas no cotidiano têm ido além das punições legais já que existem situações que podem ser consideradas como punições ilegais praticadas sob a tutela do Estado.

O relatório Final do Projeto do Centro de Defesa Técnico-Jurídica de Adolescentes de SP que analisou casos referentes às unidades da FEBEM da cidade de São Paulo, entre junho de 2002 e junho de 2003 (Sposato, 2003) faz uma descrição das inúmeras ilegalidades cometidas em relação aos processos jurídicos desses jovens. Embora os julgamentos dos atos infracionais sejam realizados em equiparação aos crimes previstos no código penal, as observações desse relatório mostram que vários passos do processo não são respeitados. $\mathrm{O}$ relatório conclui que existem irregularidades entre elas: a determinação de internação provisória, artigo 108 do ECA, realizadas inúmeras vezes sem demonstração de indícios suficientes de autoria e materialidade existindo assim muitas arbitrariedades. No caso de determinação de medida de internação, artigo 121 do ECA, não são respeitadas as reavaliações periódicas previstas para acompanhamento dos casos. Essas irregularidades ocorrem de diversas formas entre as quais: pelo não cumprimento dos prazos dos relatórios de avaliação que deveriam servir especialmente para discussão a respeito da eficácia do processo socioeducativo no regime de internação, realizados pelas equipes técnicas das unidades; pela má qualidade dos laudos que em sua grande maioria não são adequados ou conclusivos e que com isto podem aumentar o tempo para análise de progressão nas medidas; porque não são respeitados os prazos de 45 dias, no máximo, para as internações provisórias (artigo 108 do ECA) para que se julguem os casos e isto viola de forma evidente o princípio da presunção de inocência. Também, não são respeitados os prazos nas situações de internação em unidades para análise da internação provisória, as chamadas UIPs criadas pela Portaria Administrativa $\mathrm{n}^{\circ} 351 / 96$ para cumprir o disposto no artigo 175 do ECA "Em casos de não liberação, a autoridade policial encaminhará, desde logo, adolescente ao representante do Ministério Público, juntamente com cópia dos autos de apreensão, ou boletim de ocorrência. § $1^{\circ}$ Sendo impossível a apresentação imediata, a autoridade policial encaminhará o adolescente a entidade de atendimento, que fará a apresentação ao representante do Ministério Público no prazo de 24 horas"; entre tantas outras.

Além do não cumprimento dos prazos legais, o grupo apurou situações em que unidades projetadas para receber 62 adolescentes, na época do trabalho, comportavam 474 adolescentes divididos em 3 alas: Ala A (210 adolescentes), Ala B (110), Ala C (104) e Refeitório (50) nas quais os adolescentes eram obrigados a ficar sentados no chão o dia todo, com os braços sobre as pernas, assistindo na televisão a filmes, geralmente do gênero policial e com bastante violência; não podiam conversar nada com ninguém, nem mudar de posição pois, se uma dessas determinações fosse descumprida por algum adolescente, estes recebiam socos no estômago, na 
cabeça, ou onde o funcionário achasse que deveria bater; entre tantas outras irregularidades e ilegalidades.

No relatório são apontadas várias outras situações nas quais os adolescentes que sequer receberam julgamento, além de não saberem quando isto iria ocorrer e como isto iria ocorrer, eram obrigados a permanecer em situações de extremos sofrimentos tais como: a divisão de um só colchão por três adolescentes em condições de higiene e salubridade amplamente insatisfatórias; permanência em ambientes escuros, sem ventilação expondo-os ao contágio de inúmeras doenças como sarna e outras doenças de pele.

Além disso, o relatório apurou que estes jovens quando iam a julgamento não eram cumpridos todos os requisitos legais. O relatório, de mais de 50 páginas, traz relatos de ilegalidades, comprovados pelos conselhos tutelares de algumas unidades da capital de SP. Mas, exemplificam o que ocorre e com muita frequência, em todo estado e em muitos outros estados brasileiros.

No estudo de Assis et al. (2002) "Perspectiva de Jovens do Rio de Janeiro e seus Familiares", que tinha como objetivo compreender como os adolescentes em conflito com a lei e seus familiares vivenciam o período de restrição de liberdade e como pensam o futuro do jovem após o término do cumprimento da medida socioeducativa, a associação à ideia de "cadeia", entre os jovens, revela a falha sistemática em relação à proposta socioeducativa. E, as falas dos jovens, se repetem nos depoimentos dos familiares. Estas falas refletem, de um lado, a realidade com que são tratados durante a passagem pelo sistema; de outro, a visão punitiva cristalizada na sociedade e exercida por um segmento de funcionários das unidades. As autoras observam ainda o que vários estudos brasileiros também constatam: todas as imagens que as famílias apresentam estão imersas em expressões utilizadas no universo prisional. Esse trabalho foi desenvolvido em cinco unidades de cumprimento de medida socioeducativa de privação de liberdade, existentes no Estado do Rio de Janeiro, pertencentes ao Departamento Geral de Ações Sócio-Educativas DEGASE.
A ideia de cadeia associada às unidades de internação é extremamente comum às unidades de internação de outros estados brasileiros.

A esse respeito Paiva (2003) quando se refere ao Ambiente Físico das unidades de internação em todo Brasil, aponta para o fato de que 71 por cento delas não são consideradas adequadas às necessidades de propostas pedagógicas. As inadequações variam desde a inexistência de espaços para atividades esportivas e de convivência até as péssimas condições de manutenção e limpeza. Salienta ainda que, dentre aquelas consideradas adequadas, algumas o são mais para a manutenção da segurança do que para o desenvolvimento de uma proposta verdadeiramente socioeducativa, visto que muitas unidades mantêm características tipicamente prisionais.

Assim, podemos dizer que, além das punições que os adolescentes recebem, previstas no ECA, eles passam por castigos e humilhações de muitos tipos e intensidades muitas vezes apenas por um simples furto. Com o que foi exposto podemos alegar que o jovem em conflito com a lei não só é punido como castigado, muito frequentemente de forma cruel.

O contingente de jovens em privação de liberdade é enorme? A Maioria deles é extremamente perigosa?

O mito do hiperdimensionamento do tamanho da população de jovens que entra em conflito com a lei, decorre da descontextualizarão das notícias veiculadas nos meios de comunicação. Tais notícias não são dimensionadas em relação ao conjunto da criminalidade em geral. Se assim o fosse, ainda segundo a ANDI (2002) se veria que essas infrações praticadas por jovens não alcançam $10 \%$ do total de delitos registrados em geral. Dos atos infracionais praticados por jovens no Brasil, cerca de 60 por cento deles ocorrem sem ameaça de violência à pessoa, porque a maior parte dos delitos cometidos e registrados é classificada como furto.

O mito da periculosidade dos jovens infratores é formatado pela ênfase dada pela imprensa aos atos infracionais praticados com violência à pessoa. $\mathrm{O}$ que se enfatiza na mídia não são os atos mais frequentes, furtos, mas sim os mais graves e ainda, sem o devido dimensionamento social. 
As notícias sobre os tipos de atos graves e violentos são as que de fato chegam à mídia. Contribui-se assim, para a formação de uma imagem de alta periculosidade em geral.

\section{Para a ANDI (2002, p.9):}

A mídia brasileira não atinge o alvo da boa cobertura, ferindo o direito do leitor por uma informação propositiva e de qualidade sobre a violência que envolve crianças e adolescentes.

Silva e Gueresi (2003) discutindo a pesquisa denominada Mapeamento da Situação das Unidades de Execução de Medida Socioeducativa de Privação de Liberdade ao Adolescente em Conflito com a Lei, em todo Brasil, realizada conjuntamente pelo IPEA e pelo Departamento da Criança e do Adolescente (DCA), da Secretaria dos Direitos Humanos, do Ministério da Justiça, no último semestre de 2002 nos mostram uma situação que pode mudar a impressão de que os problemas são tão grandes que praticamente não podem ser resolvidos. $\mathrm{O}$ hiperdimensionamento do tamanho da população que é encaminhada para internação cai por terra quando observamos os números de internos em instituições em relação à população geral do país da mesma faixa etária.

A partir das informações levantadas pelo mapeamento sobre o perfil dos adolescentes privados de liberdade no Brasil, obtém-se o seguinte quadro síntese. Entre os meses de setembro e outubro de 2003, o número total de jovens, no país, que se encontravam privados de liberdade por terem praticado atos infracionais era de 9.555, ou seja, menos de $10 \mathrm{mil}$ adolescentes. Esse número é muito pequeno quando comparado ao total de adolescentes na idade de 12 a 21 anos existentes no Brasil (em torno de 33 milhões). Isso significa que para cada 10 mil adolescentes brasileiros, existem menos de três adolescentes privados de liberdade.

As principais características da população que se encontrava em privação de liberdade, segundo a mesma pesquisa, são: 90 por cento dos jovens são do sexo masculino; 76 por cento com idade entre 16 e 18 anos; mais de 60 por cento são considerados não brancos; 51 por cento não frequentavam a escola na época da Internação; 49 por cento não trabalhavam na época da internação; e 81 por cento viviam com a família quando praticaram o delito pelo qual foram presos.
A grande maioria dos internos não havia concluído o ensino fundamental, quase 90 por cento deles. Os principais delitos praticados por esses adolescentes foram: roubo (29,5 por cento); homicídio (18,6 por cento); furto ( 14,8 por cento); e tráfico de drogas ( 78,7 por cento). É necessário lembrar que a distribuição dessas proporções varia conforme características dos estados, regiões e municípios.

Esses 9.555 internos em unidades de privação de liberdade e de internação provisória encontravam-se assim distribuídos pelas regiões e Estados do Brasil entre setembro-outubro de 2002 (Estados; n ${ }^{\circ}$ de adolescentes; e proporção entre $\mathrm{o} \mathrm{n}^{\circ}$ de internos para cada 10 mil adolescentes do Estado):

NORTE - número total de internos: 469 [Acre $61(7,4)$; Amapá 65 $(8,4)$; Amazonas $116(2,2)$; Pará $142(1,4)$; Rondônia $37(1,8)$; Roraima 32 $(5,3)$; Tocantins $16(0,6)]$.

CENTRO-OESTE - número total de internos: 626 [Distrito Federal $247(6,0)$; Goiás $118(1,3)$; Mato Grosso $96(1,8)$; Mato Grosso do Sul 165 $(3,9)]$.

SUDESTE - número total de internos: 5.460 [São Paulo 4.429 (6,3); Minas Gerais 333 (0,9); Espírito Santo 46 (7,4); Rio de Janeiro 652 $(2,7)]$.

NORDESTE — número total de internos: 1.696 [Alagoas $39(0,6)$; Bahia 343 (1,2); Ceará 373 (2,4); Maranhão 89 (0,6); Paraíba 219 (2,9); Pernambuco 450 (2,0); Piauí 85 (1,4); Rio Grande do Norte $55(0,9)$; Sergipe $43(1,1)]$.

SUL - número total de internos: 1.304 [Paraná $341(1,9)$; Santa Catarina $119(1,2)$; Rio Grande do Sul $844(4,6)]$.

Nessa mesma pesquisa são mostradas as características da população geral no Brasil, dessa mesma faixa etária, que evidenciam um quadro de profundas desigualdades sociais, destacando-se as diferenças no rendimento escolar em função da raça/cor do adolescente, em que os jovens negros são mais pobres que os jovens de cor branca, e a existência de um grande contingente, de meninos e meninas entre 12 a 18 anos, que se encontra excluído da escola e do mercado de trabalho. 
Como podemos observar, por esses dados, a maior parte dos jovens em internação encontra-se no sudeste. Mais especificamente em São Paulo. Mesmo assim, a proporção populacional não é grande em termos de número de jovens em relação a cada 10.000 jovens da mesma faixa etária.

Em suma: no Brasil, pelo último levantamento existiam menos de 10 mil jovens privados de liberdade. Não é possível que não se tenha a possibilidade de implementar propostas socioeducativas adequadas para uma população que relativamente ao Brasil é pequena. Sobretudo, quando se levam em conta as médias altíssimas de custos mensais, por jovem internado, existentes em muitas unidades de internação em todo país, também mostradas no mesmo estudo.

\section{O ideário do SAM e do antigo código de menores permanecem}

O Estado de São Paulo é o único a continuar com a sigla FEBEM. Todos os demais estados brasileiros já mudaram pelo menos a nomenclatura de seu sistema socioeducativo.

$\mathrm{O}$ antigo sistema das unidades da FUNABEN que fazia parte da Política Nacional de Bem-Estar do Menor (PNBEM) e era ligada diretamente à Presidência da República e foi considerada um fracasso em relação à melhoria da atenção direta ao adolescente porque suas unidades mantiveram o mesmo padrão correcional e repressivo herdado do SAM Serviço de Assistência ao Menor. Este por sua vez, teve sua existência entre os anos de 1942-1964 e adotava o modelo de atendimento do tipo correcional-repressivo. Alguns dos apelidos das unidades de reclusão do SAM eram: "universidade do crime", "sucursal do inferno", entre outros (Costa, 1998).

Para Sposato (2002) a FUNABEM surge como instrumento político e de propaganda da ditadura militar. Inaugurada no dia $1^{\circ}$ de dezembro de 1964, com a atribuição de coordenar uma Política Nacional de Bem-Estar do Menor, inicia e consolida o que se convencionou chamar de "conhecimento biopsicossocial". Como parte das políticas militares, a FUNABEM foi incorporada como um objetivo nacional, constando do manual da Escola Superior de Guerra. As ramificações estaduais e municipais deram origem às FEBENS, e é assim que em 1976 é criada a FEBEM/SP, vinculada à FUNABEM.
O que se observa hoje é que a FEBEM e muitas outras unidades de outros estados funcionam ainda com as "mentalidades" existentes desde a época do SAM. Não é coincidência o fato de receberem o mesmo tipo de avaliação. Em São Paulo criou-se um Grupo de Trabalho pelo Fechamento da FEBEM que mantém um site mencionado anteriormente $<$ http://www.geocities.com/fecharfebem>. Nesse endereço encontram-se disponíveis um grande número de relatórios com as compilações de denúncias relativas à violação de direitos humanos, nacionais e internacionais. Além disso, há no site vários questionamentos a respeito dos motivos da manutenção de instituições como a FEBEM que segundo os coordenadores do site, constituem-se em campos de torturas, maustratos e tratamentos desumanos. Os coordenadores do site denominam a FEBEM como "Torturabem - A Universidade Paulista do Crime".

As diversas compilações de maus tratos e torturas que são dirigidas aos jovens privados de liberdade, além de afrontar o mínimo da dignidade humana e o atual estágio democrático em que pensamos viver, afronta de forma direta a ordem jurídica vigente no país. Diversos dispositivos normativos são violados quando se permite que um jovem cumpra medida, supostamente, socioeducativa de internação em unidades prisionais semelhantes a masmorras. Muitos desses jovens cumprem medida de internação sem que esta seja de fato a melhor alternativa para o seu processo de desenvolvimento e para a própria sociedade que não conseguirá dar a eles a oportunidade de resignificar seus projetos de vida. É necessário lembrar, só para dar um exemplo de inadequação e injustiça da medida de internação, que em muitos estados brasileiros, jovens pobres são internados por tráfico de entorpecentes, simplesmente por correspondência ao código penal que considera este crime como hediondo. São eles os chamados "aviõezinhos" que portam e entregam drogas sem ter, muitas vezes, cometido nenhum ato violento que justificasse medida de internação. Poderiam ser encaminhados para programas que lhes dessem a possibilidade de mudar substancialmente os rumos de suas vidas. No entanto, são encaminhados a instituições totais na qual ficam sujeitos à cultura prisional perversa existente no país. São submetidos como afirma Dejours (1998) “a processos de dessocialização progressivo que sabidamente afetam os alicerces da identidade". Enquanto isto acontece, muitas vezes, jovens das camadas médias que tenham cometido atos violentos de atentado à vida respondem os seus processos em liberdade. 
No Brasil existem várias experiências consideradas como "boas práticas" no que diz respeito a programas socioeducativos relativos a: prestação de serviços à comunidade; liberdade assistida; inserção em regime de semiliberdade; e internação em estabelecimento educacional. Seria necessário, portanto, reforçá-las para que estas, ao invés de quase morrerem à míngua, por falta de repasses de verbas públicas, substituam as instituições que ferem profundamente os direitos de crianças e adolescentes.

Vivemos uma situação muito ambígua. Se por um lado, as leis brasileiras são avançadas, no sentido de dar bases conceituais à Proteção Integral à Infância e à Adolescência através de Políticas Públicas, por outro, as práticas institucionais encontram-se ainda, muito aquém do proposto e aceito eticamente. Se levarmos em conta que esses jovens: não formam um contingente tão grande quanto pode parecer à primeira vista; que as periculosidades a eles atribuídas fazem muito mais parte de nossas impressões do que de produto da apuração de fatos; e que além de punições legais estes jovens sofrem inúmeras punições ilícitas; e, se considerarmos ainda que existem propostas socioeducativas capazes de oferecer alternativas dignas e eficazes, não há como continuar a tolerar a situação que encontramos no tratamento dos jovens que entram em conflito com a lei em nosso país.

Não podemos aceitar a rotinização dos massacres, das torturas e das humilhações por mecanismos que, como afirma Dejours (1998) produzam a banalização do mal. Não podemos deixar que nossos sentimentos de insegurança nos coloquem numa cultura do medo que segundo Glassner (2003) desloca nossa atenção fazendo com que os problemas mais sérios continuem amplamente ignorados. Neste caso, há ausência quase que por completa de políticas públicas de atenção e proteção para a infância e juventude brasileiras.

\section{Referências}

ANDI - Agência de Notícias dos Direitos da Infância. (2002). Balas perdidas. Brasília, DF. <http://www.andi.org.br>

Assis, S. G., Minayo, M. C. S. \& Constantino, P. (2002). Relatório de Pesquisa: Cumprindo medida socioeducativa de restrição de liberdade: Perspectiva de Jovens do Rio de Janeiro e seus familiares. Rio de Janeiro.

BRASIL. Ministério da Justiça. (1990). Lei n ${ }^{\circ} 8.069 / 90$ - Estatuto da Criança e do Adolescente. Brasília.

Costa, A. C. G. (1998). Um histórico do Atendimento socioeducativo aos Adolescentes Autores de Ato Infracional no Brasil: Mediação entre o Conceitual e o Operacional. In Políticas públicas e estratégias de atendimento sócio-educativo ao adolescente em conflito com a lei. Brasília, DF: Ministério da Justiça - Secretaria Nacional dos Direitos Humanos - Departamento da Criança e do Adolescente (DCA).

Dejours, C. (1999). A banalização da injustiça social. Rio de Janeiro: Editora Fundação Getulio Vargas.

Glassner, B. (2003). Cultura do medo. São Paulo: Francis Editora.

IPEA/MJ-DCA. (2002). Mapeamento Nacional da Situação das Unidades de Execução de Medida de Privação de Liberdade (setembrooutubro de 2002).

IPEA, DCA-SEDH \& UNICEF. (2003). Mapeamento Nacional da Situação do Atendimento dos Adolescentes em Cumprimento de Medidas Sócio-Educativas. Brasília, DF.

IPEA; DCA-SEDH \& MNMMR. (2003). Relatório de compilações das denúncias de violação de direitos nas unidades de internação de adolescentes em conflito com a lei. Brasília, DF.

Njaine, K., Minayo \& M. C. S. (2002). Análise do discurso da imprensa sobre rebeliões de jovens infratores em regime de privação de liberdade. Ciência \& Saúde Coletiva, 7, 2, pp.285-297.

Paiva, D. M. F. (2003). Sumário executivo: IPENMJ-DCA. Mapeamento Nacional da Situação das Unidades de Execução de Medida de Privação de Liberdade.

Silva, E. R. A. \& Gueresi, S. (2003). Adolescentes em conflito com a lei: situação do atendimento institucional no Brasil. Brasília: IPEA. (Texto para discussão 979). 
Sposato, K. B. (2003). Relatório final do Projeto do Centro de Defesa Técnico-Jurídica de Adolescentes em SP - 2003.

Volpi, M. (1997). O adolescente e o ato infracional. São Paulo: Cortez Editora.

\section{SIMPÓSIO 7 - PSICOLOGIA E POLÍTICAS PÚBLICAS: A FUNÇÃO SOCIAL DO ESTADO}

\section{O drama da invisibilidade}

Luiz Eduardo Soares

Um menino pobre caminha invisível pelas ruas das grandes cidades brasileiras. Esse menino, que quase sempre é negro, transita imperceptível pelas calçadas sujas das metrópoles, em que muitas vezes se abriga, expulso de casa pela violência doméstica, esquecido pelo poder público, ignorado pela comunidade, excluído da cidadania. Sem perspectivas e esperança, sem vínculos afetivos e simbólicos com a ordem social, sem pontos de conexão identitária com a cultura dominante, o menino permanece invisível, enquanto perambula pelas esquinas. ${ }^{1} \mathrm{~A}$ invisibilidade pode ser produzida pela indiferença pública à sua presença - que nunca é somente física; é sempre também social - ou pela projeção sobre ele de estigmas, os quais dissolvem os aspectos singulares que o distinguem como pessoa humana. $\mathrm{O}$ estigma estampa sobre o corpo discriminado a imagem preconcebida, que corresponde à projeção de quem porta o preconceito, anulando a individualidade de quem é observado.

$\mathrm{O}$ menino carrega consigo, pelas ruas da cidade, as dificuldades comuns da adolescência, acrescidas dos dramas da pobreza, no contexto da imensa desigualdade brasileira. Sabemos que a adolescência é uma criação histórico-cultural recente, mas também sabemos como pode ser desafiadora, do ponto de vista psicológico, com seu rosário de ambiguidades, cobranças, promessas e frustrações. Quando sobre o adolescente pobre desce o véu escuro da invisibilidade social, seu corpo físico passa a suportar um espírito esmagado, subtraído das condições que lhe infundiriam autoestima.

${ }^{1}$ É claro que esta descrição é simplificadora e cumpre apenas o propósito de oferecer as referências para a interpretação que seguirá. Ninguém é inteiramente invisível, não o é para todos, nem vivencia do mesmo modo suas implicações. 
Quando um traficante lhe dá uma arma, nosso personagem invisível recebe muito mais do que um instrumento que lhe proporcionará vantagens materiais, ganhos econômicos e acesso ao consumo; o menino recebe um passaporte para a existência social, porque, com a arma, será capaz de produzir em cada um de nós, em cada esquina, um sentimento: o medo, que é negativo, mas é um sentimento. Provocando no outro um sentimento, o menino reconquista presença, visibilidade e existência social. Recorrendo à arma, portanto, o menino invisível restaura as condições mínimas para a edificação da autoestima, do reconhecimento e da construção de uma identidade.

Nós seres humanos só existimos pela mediação do olhar generoso do outro, que nos reconhece como tais, nos devolvendo nossa imagem ungida de humanidade, isto é, qualificada, valorizada. Através do uso da arma, o menino errante estabelece uma interação, na qual se torna possível sua reconstrução subjetiva, na qual se torna viável o projeto - soi disant estético — de sua autoinvenção. Trata-se de uma dialética perversa, em que o menino afirma seu protagonismo e se estrutura como sujeito, sujeitando-se a um engajamento trágico com uma cadeia de relações e práticas que o condenarão, muito provavelmente, a um desfecho letal, cruel e precoce, antes dos 25 anos. Além disso, sendo o medo um sentimento negativo, sua autoafirmação trará consigo o peso da culpa que corresponde à magnitude dos ressentimentos e juízos críticos sobre o ato violento pelo qual se responsabiliza. Trata-se, portanto, de uma espécie de pacto fáustico, em que o menino troca sua alma, seu futuro, seu destino, por um momento de glória, por uma experiência efêmera de hipertrofia do protagonismo, em que as relações cotidianas de indiferença se invertem: o desdém superior do outro converte-se em subalternidade humilhante, temor e obediência à autoridade armada do menino.

Como se observa, a arma nas mãos de nosso jovem personagem é muito mais que um meio a serviço de estratégias econômicas de sobrevivência. Há uma fome anterior à fome física; mais funda, mais radical e mais exigente que a fome física: a fome de existir, a necessidade imperiosa de ser reconhecido, valorizado, acolhido. Por isso, pelo menos tão importante quanto as vantagens econômicas, na cena da violência, destaca-se a relevância dos benefícios simbólicos, afetivos, psicológicos, inter-subjetivos.
Quando o menino tem acesso à arma, frequentemente, no Brasil, tem acesso também ao convívio com grupos de traficantes varejistas de drogas e armas, que se instalam nas vilas, favelas e periferias das cidades. Esse convívio proporciona um segundo benefício valioso para os jovens: a gratificação do pertencimento, a qual é tão mais intensa quão mais coeso for o grupo. Por outro lado, a coesão é diretamente proporcional ao grau de antagonismo vivenciado pelo grupo, em suas relações com os outros grupos com os quais se relacione, coletivamente. Essa é a lógica segmentar que os antropólogos conhecem, sobretudo a partir das obras de Evans Pritchard e Lévi-Strauss e que os sociólogos já haviam codificado, desde Georg Simmel. Por isso, é tão importante para meninos e meninas experimentar as emoções reconfortantes do pertencimento, aderindo a grupos segmentares, os quais tornarão a vivência do pertencimento tão mais forte quão mais violentamente confrontarem os grupos rivais. As gangues do tráfico encenam, com resultados trágicos, as regras inconscientes da vida social, na ausência de alternativas construtivas, capazes de sublimar a violência, simbolizando-a e a transferindo para outras linguagens, como a dos esportes, por exemplo.

Como os municípios, no Brasil, não têm polícias (apenas Guardas Civis, em geral limitadas à proteção do patrimônio público), só poderiam enfrentar a violência criminal com políticas preventivas de natureza nãopolicial, ainda que sempre contando com a colaboração das polícias estaduais (a militar e a civil). Mas a limitação pode converter-se em virtude, se houver criatividade. Seria necessário instituir fontes alternativas de atração ou recrutamento dos jovens, capazes de competir com o tráfico, oferecendo pelo menos as mesmas vantagens proporcionadas pelo tráfico. Em outras palavras, para competir, para disputar menino a menino, menina a menina com a fonte de sedução criminosa, o poder público municipal teria de proporcionar benefícios materiais, como emprego e renda e, simbólicoafetivos, como valorização, acolhimento e pertencimento, restituindo visibilidade e autoestima, o que, por sua vez, exigiria uma espécie de "customização" das políticas públicas, focalizando seus destinatários como indivíduos em grupo, não como massa amorfa ou mero segmento popular. Para valorizar cada jovem é preciso aplicar políticas públicas que criem oportunidades de exercício de suas virtudes e potencialidades criativas e expressivas. Mas isso ainda não basta. É necessário criar também as 
condições para que as virtudes expressas sejam identificadas e reconhecidas, o que requer estruturas dialógicas intra e intergrupais.

O grande desafio está em combinar geração de emprego e renda com a sensibilidade para o imaginário jovem, para suas linguagens culturais específicas. Os jovens pobres das periferias e favelas não querem uma integração subalterna no mercado de trabalho. Não desejam ser engraxates dos nossos sapatos, mecânicos dos nossos carros ou pintores de nossas paredes. Não querem repetir a trajetória de fracassos de seus pais. Não pretendem reproduzir o itinerário de derrotas da geração precedente. Os jovens pobres desejam o mesmo que nossos filhos: internet, tecnologia de ponta, arte, música, cinema, teatro, TV, mídia, cultura, esporte. Desejam espaços para expressão de sua potencialidade crítica e criativa; espaços e oportunidades para sua afirmação pessoal; chances para alcançar reconhecimento e valorização, escapando ao manto aniquilador da invisibilidade social discriminatória. Há um grau de narcisismo que é saudável, indispensável, construtivo, como pré-condição da autoconstrução do sujeito, enquanto ser social cooperativo, solidário, disposto a jogar o jogo pacífico da sociabilidade. Portanto, as novas políticas públicas, voltadas para a disputa com o tráfico e para a sedução da juventude, teria de instituir-se em sintonia com os desejos e as fantasias que circulam nas linguagens culturais da juventude, combinando políticas de emprego e renda, capacitação e complementação educacional, com o desejo pelos temas e as práticas cujos eixos são arte, música, cultura e mídia.

No plano municipal, há muito a fazer, mesmo sem as polícias. Nesse nível. a intervenção efetivamente capaz de prevenir a violência e a criminalidade é aquela que visa alterar as condições propiciatórias imediatas, isto é, as condições diretamente ligadas às práticas que se deseja eliminar; não é a ação voltada para mudanças estruturais, cujos efeitos somente exerceriam algum impacto desacelerador sobre as dinâmicas criminais em um futuro distante - o que, evidentemente, não significa que essas mudanças, de tipo estrutural, não devam ser realizadas. Claro que elas são necessárias e urgentes, e em grande extensão, por suas virtudes intrínsecas, para melhorar o Brasil e para transformar as condições que favorecem a violência. Mas não são suficientes, nem substituem as intervenções tópicas, via políticas sociais indutivas, nas dinâmicas imediatamente geradoras da violência. Um exemplo: com frequência, territórios limitados concentram as práticas criminais, que tendem à reiteração, conformando padrões e permitindo tanto a previsão quanto a antecipação. Esse quadro constitui fenômeno amplamente reconhecido pela criminologia internacional. Sendo assim, antes mesmo que as eventuais reformas das estruturas socioeconômicas produzam seus efeitos, iniciativas tópicas bem focalizadas, que incidam de modo adequado e eficiente sobre as condições e circunstâncias imediatamente ligadas à dinâmica criminal, podem alcançar resultados excelentes. É preciso interceptar as dinâmicas imediatamente geradoras dos fenômenos, o que exige diagnósticos sensíveis às complexidades dos contextos sociais e devem ser complementados por planejamento qualificado e por avaliações sistemáticas, que propiciem permanente monitoramento de todo o processo de intervenção pública, mesmo quando se dá em parceria com iniciativas da sociedade civil.

Creio que demonstrei a possibilidade de que os municípios colaborem para a redução da violência criminal, mesmo sem dispor de instituições policiais. Cumpre, agora, considerar os dados gerais do problema da violência criminal, no Brasil, incorporando as questões que envolvem diretamente as instituições estaduais, particularmente as polícias.

Nosso problema mais dramático, no Brasil, na área da segurança, é o verdadeiro genocídio a que vem sendo submetida a juventude brasileira, especialmente a juventude pobre do sexo masculino e, em particular, os jovens negros. Em 1999, na cidade do Rio de Janeiro, por exemplo, em cada grupo de cem mil habitantes, 239 jovens do sexo masculino, com idades entre 15 e 29 anos, foram vítimas de homicídios dolosos. Em 2000, no estado do Rio, 2.816 adolescentes morreram assassinados (107,6 por cem mil adolescentes - a média brasileira era de 52,1, no ano 2000, tendo sido de 30, em 1980). O estado do Rio de Janeiro só era superado, nessa contabilidade mórbida, pelo estado de Pernambuco. Já a cidade do Rio de Janeiro ficava atrás de outras três capitais: Recife, Vitória e São Paulo, nesta ordem. Em 1991, os homicídios dolosos no estado do Rio, nessa mesma faixa etária, correspondiam a 76,2 por cem mil jovens. Enquanto as mortes por homicídio não ultrapassam $4 \%$ do conjunto das mortes, no universo da população brasileira, entre os jovens, o número se elevava a $39 \%$. Os dados vêm se tornando cada vez mais drásticos. Em 2002, quase 45 mil pessoas foram vítimas de homicídios dolosos, no Brasil. A taxa de 
homicídios dolosos por 100 mil habitantes elevou-se para 27. Segundo a pesquisa mais recente divulgada pelo IEGE em abril de 2004, quando se consideram apenas os homicídios dolosos que atingem a população masculina, a taxa alcança 49,7 (por 100 mil habitantes). Circunscrevendose o universo masculino jovem brasileiro (entre 15 e 24 anos), obtém-se a espantosa taxa de 95,6. Tomando-se a mesma população (masculina jovem), mas restringindo a observação ao estado do Rio de Janeiro, a taxa ainda mais assustadora: 205 por 100 mil (jovens do sexo masculino). No estado do Rio, houve 42,9 homicídios dolosos por 100 mil habitantes, em 1999 e 44,5 em 2002. Registre-se que os dados seriam mais alarmantes se incluíssemos todos os crimes letais, como os latrocínios (ou roubos seguidos de morte) e os autos de resistência (mortes provocadas por ações policiais, muitas das quais são ilegais e caracterizam extermínio). No estado do Rio, os autos de resistência cresceram 236,6\% nos últimos seis anos: foram 355, em 1998 e caíram para 289 em 1999 - ano em que implementamos um conjunto de reformas nas polícias fluminenses, orientadas para a modernização, a moralização e a participação social, visando reduzir a corrupção e a brutalidade policiais (duas faces da mesma moeda) e ampliar a eficiência, nos marcos do respeito às leis e aos direitos humanos. Em 2000, o número de autos de resistência subiu para 441. As mortes provocadas pelas polícias alcançaram patamar mais elevado, em 2001: 592 casos. A situação agravou-se, em 2002, quando o número de casos saltou para 900. A tendência ascendente foi mantida em 2003, quando houve 1.195 casos. O ano em curso, 2004, prenuncia elevação ainda mais trágica.

Voltando a focalizar os homicídios dolosos, assinale-se que o mais extraordinário e paradoxal é a natureza autofágica desse genocídio: são, sobretudo, jovens pobres (entre 18 e 24 ou 29 anos, conforme o critério aplicado) que matam jovens pobres. Eles estão dos dois lados desse processo fratricida, como vítimas e perpetradores. A magnitude do problema é tal, que suas consequências já são perceptíveis na estrutura demográfica brasileira. A estratificação etária da população apresenta um déficit de jovens do sexo masculino apenas comparável ao que se verifica nas sociedades que se encontram em guerra.

Para que se compreenda a dinâmica em que tantas vidas estão sendo prematura e violentamente sacrificadas, é preciso reunir os seguintes ingredientes: (a) acolhimento familiar, comunitário e escolar deficientes; (b) falta de perspectivas de integração social plena; (c) ausência do Estado, nos territórios urbanos pauperizados; (d) constituição, nas periferias, vilas e favelas, do varejo do tráfico de armas e drogas como fonte de recrutamento para atividades ilegais; (e) desdobramento do tráfico em ampla variedade de práticas criminais, graças à disponibilidade de armas. Esses fatores combinados, afetando segmentos da juventude pobre, fazem com que determinados grupos - certamente, uma minoria - sejam atraídos pela sedução do tráfico e se liguem à organização criminosa. Com triste frequência, essa ligação condenará parte significativa desses jovens a um itinerário de delinquência e à morte precoce e violenta.

As vantagens oferecidas pelo tráfico, materiais e simbólico-afetivas, como vimos, em certa medida e com consequências perversas, compensam a carência de autoestima, a invisibilidade social (provocada pelos estigmas ou pela indiferença), a falta de vínculos identitários fortes com a comunidade, a escola ou a família, a falta da gratificação proporcionada pelo lazer e o esporte e a precariedade de perspectivas de integração plena no mercado, em um contexto no qual a sociedade parece só valorizar o status que brilha no consumo ostentatório.

Juventude pobre recrutada por unidades locais do tráfico de armas e drogas, responsável pelo varejo desse comércio ilegal: aí está o centro de uma de nossas maiores tragédias nacionais, o nervo do processo autofágico e genocida. Os crimes que têm essa origem não são apenas os homicídios que decorrem das rivalidades entre os grupos varejistas. Os roubos à mão armada, os roubos seguidos de morte, os sequestros, em todas as suas variações, os roubos a residências, bancos e ônibus, os roubos e furtos de veículos, os roubos de cargas, todas essas práticas são estimuladas e, em muitos casos, viabilizadas pela disponibilidade de armas, traficadas por iniciativa e financiamento dos mercadores de drogas. $\mathrm{O}$ tráfico coopta um exército de reserva para a indústria do crime e determina um nível intenso de atividade criminosa, em função da conveniência econômica de preencher a capacidade ociosa do armamento. Nesse mercado clandestino, por analogia com a lógica da economia formal, a produtividade perversa do crime tende a ser elevada até alcançar a plena utilização da capacidade produtiva instalada — o armamento - empregando a mão de obra mobilizável, nesse caso os recrutas seduzidos principalmente no varejo das drogas. 
A racionalidade do mercado do crime, quando estruturado em torno do tráfico de armas, induz à expansão da intensidade e da variedade das atividades criminosas, o que implica não apenas que a tendência seja o crescimento do número de crimes, mas também que a tendência seja o aumento do grau de risco e violência, porque mais comumente são utilizadas armas de fogo. Evidentemente, essa lógica não se afirma em ambiente vazio de determinações circunstanciais. Sua aplicação depende da taxa de impunidade ou da taxa de risco com a qual se opera o tráfico de armas e drogas e se praticam as diversas modalidades de crime, assim como é função do repertório de alternativas legais e ilegais, isto é, das vantagens ou desvantagens relativas das estratégias de sobrevivência, afirmação pessoal, acumulação econômica, exercício de poder e acesso ao consumo. O grau de promiscuidade das polícias com as organizações criminosas constitui também variável decisiva nesse quadro. Observe-se que o excesso de armas não é apenas um indutor do crime; é também uma razão pela qual conflitos fúteis acabam tendo desfecho trágico: pequenos desentendimentos em um bar, regados a álcool, convertem-se em crimes letais, apenas porque há uma arma disponível.

Portanto, aos empreendedores do mercado criminal interessa a existência de contingentes cada vez mais numerosos de jovens sem esperança de integração à cidadania plena, porque esse fenômeno amplia a oferta, isto é, as chances de recrutamento de força de trabalho descartável (e disposta a servir a propósitos ilegais) e reduz seu preço - restringindo o custo de produção do crime e, consequentemente, ampliando a expectativa de lucro.

Por outro lado, se a cena mais dramática é a do teatro de guerra os espaços urbanos abandonados pelo poder público, onde se instala o varejo do tráfico e ocorrem os confrontos entre grupos rivais - a cena decisiva, da qual emana o roteiro da tragédia, onde atuam seus verdadeiros protagonistas, os agenciadores últimos da violência, esta se situa bem longe dali. Seus atores são os operadores do atacado do tráfico de armas e drogas, que moram bem, falam línguas estrangeiras, têm acesso a informações privilegiadas, acionam recursos sofisticados de comunicação, administração e lavagem de dinheiro. São os "criminosos de colarinho branco", que estão longe de ser filhos da pobreza, mas se alimentam dela, como abutres. A cena com tiros e sangue chama a atenção da cidade e mobiliza a polícia, mas os capítulos principais, nos quais a ação decisiva transcorre, são invisíveis e raramente despertam o interesse policial. Nessa esfera, a promiscuidade entre a criminalidade e as instituições apresenta riscos ainda mais graves do que aqueles que derivam dos acordos locais entre policiais e traficantes, operadores do varejo — acordos já por si extremamente perigosos e degradantes.

Já seria bastante: jovens morrendo, numa dinâmica que os recruta, submete-os a confrontos bélicos constantes e os distribui em atividades ligadas a múltiplas formas de criminalidade, enquanto os operadores do atacado permanecem intocados. Mas o fenômeno é ainda mais complexo e grave. Ultrapassa as fronteiras da questão criminal e lança a violência a um patamar político, de profundas implicações sociais. O que se passa, hoje, no Brasil, em muitas áreas urbanas empobrecidas e negligenciadas pelo poder público, é um ultraje à democracia, uma demonstração da incompletude do processo de transição, que nos legou a Constituição de 1988. Algumas comunidades locais são submetidas à dupla tirania, exercida por traficantes armados e policiais corruptos (segmentos minoritários mas significativos das polícias). Esse poder paralelo as subtrai da esfera de abrangência do Estado democrático de direito. Sob esse duplo despotismo, são suprimidas as liberdades elementares, como os direitos de ir e vir, de expressão, participação e organização. Comunidades inteiras vivem, hoje, em algumas grandes cidades brasileiras, sob um regime de terror e impotência, imposto pelos códigos arrogantes do tráfico e o arbítrio da polícia (personagens que frequentemente se associam), enquanto o conjunto da sociedade parece tolerar o convívio com o horror e começa a naturalizá-lo. A banalização da violência é o preâmbulo da barbárie.

Essa reflexão conduz a uma conclusão: os atores sociais verdadeiramente comprometidos com a democracia e a justiça, em seus sentidos mais profundos e radicais, todos aqueles para os quais direitos humanos são mais que peça retórica ou referência remota e abstrata, todos os empenhados na construção de um país menos iníquo e hipócrita, racista e preconceituoso, misógino, homofóbico e violento, em um mundo pacífico e plural, devemos levar a sério o desafio de implementar políticas de segurança sintonizadas com estes valores, sensíveis à complexidade multidimensional dos fenômenos pertinentes e traduzidas, portanto, em programas pluridisciplinares e intersetoriais - os quais, por sua vez, 
exigiriam novos sujeitos da gestão pública e, portanto, uma reforma do Estado distinta daquela operada pelo neoliberalismo. Nada disso é trivial ou incontroverso: persistem, nas esquerdas, as resistências ao tema segurança pública, em sua especificidade; perduram as dificuldades em reconhecer a importância do papel das instituições policiais nas sociedades democráticas, continuam fortes as crenças segundo as quais políticas que reduzem violência são apenas aquelas de longo curso, que revertam o quadro macroestrutural das iniquidades socioeconômicas. Sem descurar da evidente importância das políticas de longo curso voltadas para reverter as macroestruturas injustas e opressivas, urge reconhecer a necessidade imperiosa de políticas preventivas tópicas emergenciais, factíveis e baratas, que não mudam estruturas, mas salvam vidas - necessidade sobretudo para os que mais sofrem seus efeitos: os mais pobres, jovens e negros. Segurança não é questão conservadora, de conservadores e dos abastados. É problemática de interesse universal, mas cuja carga mais dramática se concentra nos que, supostamente, seriam defendidos e representados pelas esquerdas, exatamente aqueles segmentos políticos que mais se furtam a enfrentar este desafio, em toda sua complexidade. Complexidade na qual se inscrevem o presente imediato e as urgências da vida dos subalternos e excluídos. Está obsoleto o discurso marxista ortodoxo, que pensa a ordem pública como mera preservação do status quo explorador, condição para a simples exação da mais-valia. Esta perspectiva traz como contrapartida e fundamento teórico a concepção leninista do Estado e de seus aparelhos, como instrumentos de dominação de classe, independentemente de suas formas, regimes e formatos institucionais ou legais. Nós brasileiros aprendemos no lombo, sobretudo os defensores das camadas populares, quais as diferenças entre democracia e ditadura. A perempta indistinção leninista não resistiu à experiência histórica do século XX. A ordem pública assentada no pacto constitucional democrático é processo dinâmico, aberto a redefinições progressivas e representa, em suas limitações e contradições, a pré-condição para a realização dos projetos inspirados na equidade e na liberdade. A tradução prática desta ordem, expressiva do pacto democrático, na vida cotidiana das massas populares, na periferia, é a defesa da vida e do exercício dos direitos políticos mais elementares, conquistados em 1988, fixados na Carta Magna e jamais estendidos às maiorias. Segurança é, para todos, um direito; direito que, no "andar de baixo" de nossa sociedade, converteu-se em garantia absolutamente prioritária e condição de realização civilizatória. Ou os democratas compreenderão o que isso significa ou haverá o risco de que o retrocesso autoritário prospere no rastro dos aventureiros de plantão predadores políticos, que se alimentam do medo. 


\section{PALESTRAS}

\section{Emergencia de las concepciones sociales en el movimiento cultural} argentino de principios del siglo $\mathrm{XX}$

Cristina Di Doménico

Situarse a principios del siglo XX para dar cuenta de la emergencia de las concepciones sociales en el movimiento cultural de la Argentina es, sin duda, y como toda periodización, una arbitrariedad. Para salvarla, se impone una muy breve mirada retrospectiva al siglo precedente, y en especial a esa transición temporal que define al intersiglo, tanto en el júbilo que expresa haber transitado una centuria más, como en la lamentación por todo aquello que en los cien años dejados atrás ha quedado sin remediar.

Los años 1800 transcurrieron en Argentina dramáticamente, como en la mayoría de los países latinoamericanos que se debatían en sus luchas independentarias (con la excepción de Brasil). Pero las conquistas armadas no bastaron para proseguir el camino hacia la organización nacional; los años que siguieron a 1810 fueron cruda expresión del debate interior encarnado en los distintos grupos de poder que representaron posiciones extremas. Unitarios o federales exhibieron, a veces ambiguamente, las distintas face tas de la tensión entre lo rural y lo urbano, entre la centralización y la descentralización del poder político, entre la dependencia y la independencia económica, entre lo criollo y lo extranjero, entre lo popular y lo oligárquico ...

Como se ha señalado (Jitrik, 1970) el proceso de integración de la economía argentina al concierto mundial no fue pensada por los hombres de Mayo (el grupo ilustrado que gestó la revolución) en términos de dependencia. Ellos aspiraron a desembarazar a la naciente argentina del monopolio español, pensado no solo económicamente sino también política y culturalmente. Para la denominada "generación del 37" (la de J. B. Alberdi, D. F. Sarmiento, E. Echeverría), el libre comercio con países como Francia e Inglaterra, implicaba acceder a los bienes de la "civilización" a cambio de las vernáculas materias primas. Dos cosas lo impidieron: el país estaba ocupado en sus propias luchas intestinas y no centraba su interés en la producción; y no existía ninguna condición para garantizar la reciprocidad en el intercambio.

Definido el modelo económico como agroexportador y dependiente, hacia fines, del siglo XIX ni la modernización del campo ni el desarrollo urbano contrariaron un ideario oficial, de clase dominante, que solo se preocupaba por mejorar los sistemas colonizados de intercambio para preservar sus propios ingresos. Los verdaderos planificadores del modelo seguían siendo extranjeros, los terratenientes seguían enrique-ciéndose y la enorme multitud trabajaba sin esperanzas, bajo condiciones laborales indignas y con legislaciones abusivas.

Hacia fines del siglo XIX la generación del 80 había elaborado un proyecto de transformación basado en una economía liberal, dentro de cuya concepción el positivismo se constituía como eje vertebrador. Tal ideología permeó la política, las instituciones, la educación, la moral... y a la vez, viabilizó interpretaciones sobre el "carácter nacional" o la "mente colectiva" en el necesario contexto de organización de regímenes organizativos compartidos Como afirma el autor que ha estudiado la emergencia de una psicología social en nuestro país (Vilanova, 2000), la personalidad colectiva argentina era principal preocupación de la época ya que se la entendía como la base de la constitución de una identidad nacional; y esa comprensión “... está incidida por ciertas formas prepsicológicas de pensamiento, particularmente los idearios de Juan Bautista Alberdi, Faustino Sarmiento y otros organizadores de la nación" (p.7). En ello se alude a la influencia, en ideario e ideología, que la Generación del 80 recibe de la Generación del 37.

Vale recordar que los hombres del 37, reactivos al gobierno de Rosas, nacidos en la etapa revolucionaria de Mayo y educados en las instituciones laicas creadas por Rivadavia, conformaron la primera elite intelectual nacional, que tenía por objetivo llevar los principios revolucionarios hasta la constitución y organización del Estado Nacional. Esos objetivos se perfilaron desde mediados del siglo XIX y a partir de la sanción de la Constitución Nacional en 1853. Estos hombres, alentados de patriótico espíritu, en el trazado de su proyecto identification tres obstáculos: el desierto montonero, la debilidad étnica de gauchos, aborígenes y mestizos, y la herencia española, entendida como una moral de corruptela y dejadez. 
Un concepto rector para esta generación fue el de nacionalismo, en el intento de determinar las concepciones singulares de nuestra historia y, a partir de allí, la estructura institucional que había de tipificarnos como nación (De la Camara, 1956). El mismo autor afirma, asimismo, que:

el concepto de nacionalismo, que deriva del romanticismo ideológico social, es el ángulo de mayor riesgo en las ideas contemporáneas. Casi podría decirse que es el rincón de vidrio de nuestra civilización (p.61).

Los ideales románticos del siglo XIX recuperaron al individuo socializado, al hombre social. Ese es el hombre que vive en comunidad, y que puede ser llamado ciudadano.

La dignidad de la condición humana que trajo el Humanismo, se resuelve ahora en condición de la dignidad humana para el ejercicio de la convivencia armoniosa ... (Di Filippo, 1957, p.8).

Estos mismos ideales, a la luz de una nueva concepción sobre el hombre y la sociedad, animaron los proyectos de solución de la generación del 80: liberalismo económico, inmigración y educación.

La inmigración, que por su importancia e impacto permitió la definición de "la Argentina aluvial", alteró profundamente la vida criolla, sin que ello pareciera ser advertido por sus ideólogos. Pronto los inmigrantes fueron mayoría ciudadana, y por su número y por su eficacia práctica, comenzaron a perfilar otro país, divergente en expectativas y demandas al pergeñado en el seno del programa del liberalismo conservador. La clase en el poder nada hizo para radicar a estos nuevos componentes sociales que ellos mismos habían convocado, tal vez esperando su natural absorción en la tradición criolla (Romero, 1994).

Mas, como bien se ha señalado, acoger no es asimilar borrando las marcas de la diferencia, sino abrir espacios de habla y significación donde la cultura del otro se exprese, se de a conocer; es decir, acoger es estar dispuesto a aceptar una "cultura plural" (Certeau, 1995).

Esta imposibilidad de interpretar política y socialmente lo que la inmigración representaba, en términos de clases medias y proletariado, puede pensarse como un fracaso histórico de la generación del 80, que contribuyó a que el nuevo complejo social conservara su naturaleza inestable y ajena a los problemas colectivos (Romero, 1994). Esta dificultad para interpretar en un proceso complejo uno de sus aportes mas significativos - como era la inmigración en el proceso de modernización, y una falta de voluntad o voluntad deliberada - de clases gobernantes no dispuestas a ceder privilegios, dejó abierta una problemática que ninguno de los actores concurrió decisivamente a cerrar (Halperin Donghi, 1998).

En este marco referencial, tomaremos algunas expresiones culturales argentinas de este tránsito de intersiglos con el objetivo de indagar las repercusiones sociopolíticas y sus manifestaciones en este campo. Los movimientos literarios del siglo XIX, hasta el epílogo modernista finisecular, no llegaron a explicitar la diversidad de elementos del romanticismo que se había desplegado en la centuria (Ghiano, 1978). El mismo autor advierte sobre la falta de análisis sobre la realidad hispanoamericana, que llevó a grupos minoritarios a desatender urgencias sociales y aceptar acríticamente lo que arribaba como novedoso. El debate respecto a la dependencia, en este caso cultural, permanece abierto y a él concurrieron posiciones muy diversas: desde la no preocupación por la imitación e importación ya que ello no impide el logro de lo autóctono (Giusti, 1954), transitando la concepción del "adoptar-adaptar" hasta la conciencia o la necesidad de la conciencia de la dependencia (Roig, 1994).

El romanticismo, de la mano de su mayor docente E. Echeverría, vino a proclamar la recuperación de una poesía con acentos propios, y expresiva de ideas, sentimientos y pasiones generados en los propios intereses sociales. Este programa originalmente se inscribe en la resistencia al regimen rosista llevada a cabo por una generación de intelectuales en la que también se gestaron las expresiones costumbristas de la vida en el campo (Santos Vega, Fausto) y la documental protesta del Martín Fierro. Este último texto, distintivamente, analiza los diferentes componentes sociales sin caer en la antinomia civilización - barbarie planteada por la proto-sociología nacional. También esta obra clausura una etapa del romanticismo literario de intensidad social, ya que en las dos últimas décadas del siglo XIX adviene un romanticismo más preocupado por el equilibrio expresivo, marcando la transición hacia el modernismo y su empecinada búsqueda del esteticismo (vale recordar que en 1893 llega R. Darío a Buenos Aires).

Van a ser recién los años de post guerra en el principio del siglo XX los que inspiren aires de renovación y de condena a un modernismo 
entendido como resabio del europeismo. El estilo del verso libre y de la imagen prepara el advenimiento del ultraísmo de los narradores y poetas cultos de Florida, a los que se opuso una corriente de narradores y poetas populares.

\section{Florida y Boedo}

En la década de los 20 se identifica a los poetas con dos barrios: uno céntrico elegante (Florida) y otro del suburbio criollo- inmigrante (Boedo).

En el grupo de Florida militaban Borges, Marechal, Girondo, Mastronardi, Lange, entre otros; y escribían en sus propias publicaciones: Proa, Prisma, Inicial, Martín Fierro. Jóvenes al epilogar la primera guerra mundial, representantes del ultraísmo, su audacia se acunaba en el todavía vigente espejismo del progreso, de la estabilidad y de la bonanza económica para su clase.

Seleccionamos aquí algunas de las peculiaridades que se han definido para ese grupo (Anderson Imbert 1954):

- Cosmopolitismo: ya no como el europeismo idealizado del modernismo, sino como un europeismo irreverente que permite el acceso a los colores locales americanos.

- Actitud en la literatura: la literatura era un juego, hablar por hablar, el arte por el arte; la realidad era el campo donde probar el ingenio, la fantasía.

- Sentimiento: el arte debía deshumanizarse, librarse de todo sentimiento; el yo era destruido, el lirismo de la materia sustituía a la psicología del hombre.

- Temas literarios: las cosas inanimadas son protagonistas; los paisajes, telones de fondo.

- Imaginismo: a contrapelo del ritmo y la rima de los modernistas, redujeron la poesía a metáforas puras (la imagen por la imagen).

El otro grupo, el que llegaba del suburbio, del barrio de Boedo, se caracterizaba por contar con personajes revolucionarios que crearon, a partir del arte social, una literatura que ahondaba en la indagación de los problemas que se planteaban en el seno del modelo del liberalismo económico sus fórmulas incluyeron mucho de lo aprendido en la Revolución Rusa. En Boedo militaban Cesar Tiempo, Nicolás Olivari, Alvaro Yunque, Raúl Gonzalez Tuñón entre otros, y su publicación distintiva era "Claridad". Si bien Gonzalez Tuñón ha tenido afinidad con ambos grupos, debe incluírselo entre los Boedistas en razón de que "es el poeta más valioso de la literatura social y política en la Argentina a traces de una obra que desde 1930 se continúa en la atualidad" (Giordano, 1968a; 1968b).

Los boedistas, esencialmente preocupados por la justicia social, aportaron un elemento vigorizante y vitalista. La literatura como juego había de dar lugar a la literatura como expresión y testimonio de anhelos...las fábricas, los crecientes conventillos, ofrecieron otras realidades, menos poéticas, pero mas inmediatamente perceptibles que, golpeando la sensibilidad de los escritores en ciernes, los comprometían con su entorno sociocultural (Isaacson y Urquía, 1963).

Si se puede definir un epílogo para Boedo-Florida, puede puntuarse en la revolución militar de 1930 que hizo tomar partido a sus integrantes tanto en el bando (popular u oligárquico) como en las ideologías (liberales, socialistas o fascistas). Esto terminó de romper los grupos literarios restringiendo los objetivos que habían tendido a conformarlos.

\section{La cuestión social en la novela semanal}

La novela semanal pertenece al rubro de los folletines que, entre 1915 y 1930, alcanzaron tirajes que revelaron el amplio consumo de este producto que nace en el seno de las estrategias comerciales de los periódicos.

En la Novela Semanal, editada todos los lunes, la cuestión social aludía al movimiento obrero y sus formas de organización; a la metodología de protesta común en la época - la huelga - a las repercusiones de la Revolución Rusa, las respuestas de los sectores nacionalistas...

Se han analizado (Godio, 1987; 1988) los primeros referentes ideológicos del movimiento obrero argentino proviniendo del anarquismo 
y del socialismo de raíz marxista, a los que luego se sumó la tendencia del sindicalismo revolucionario. Los primeros mantuvieron disputas internas acerca de si era viable una organización en sindicatos; los socialistas, en cambio, abogaron por la constitución del propio partido político, a través del cual tomar el poder y abolir la diferencia de clases. El sindicalismo, enfrentado al parlamentarismo socialista que era decodificado como conciliador, se oponía al partido político como estrategia y reivindicaba la acción directa (huelga general) para combatir al capitalismo.

Los movimientos huelguísticos, presentes en las dos últimas décadas del XIX, intensificados con la crisis de 1890 y con la concentración de obreros en las fábricas hacia el 1900, posibilitaron la organización de las primeras agrupaciones obreras en el país.

Hitos trágicos en Argentina dieron cuenta del enfrentamiento entre la clase dominante, autora de un proyecto de exclusión social, y de la clase trabajadora. Como ejemplo pueden mencionarse: la primera huelga general nacional de 1902, iniciada por los estibadores del puerto y que promovió una escalada represiva que incluyó la sanción de la ley de estado de sitio y de Residencia; la Semana Roja a partir de los sucesos del 1 de mayo de 1909; la Semana Trágica de 1918 en los talleres metalúrgicos de Vasena; las huelgas patagónicas de los peones de estancia de Santa Cruz en 1921; las huelgas del quebracho en la década de los 20 en el noreste argentino ... Como puede notarse, todo ello en un escenario político amplio al que ya había accedido la Ley Saenz Pena (de voto obligatorio y secreto), la Reforma Universitaria del 18, los gobiernos reformistas radicales...

En el contexto de una heterogénea composición inmigratoria, el internacionalismo esgrimido por el movimiento obrero viabilizaba una integración que superaba las diferencias de nacionalidad; era la posibilidad de una identificación que no estuviera fragmentada en la referencia al país de origen (Lobato y Zuriano, 2000).

La Novela Semanal formó parte del importante número de publicaciones que llevaron a la Argentina, a fines de los anos 20, al primer puesto en ediciones escritas en los países hispanoparlantes. Como expresión literaria ("estéticamente... enrolada en el realismo y el naturalismo decimonónicos") la Novela Semanal portaba las opiniones políticas de sus autores y tiene el valor de que sus narraciones pueden ser leídas, aunque ficciones, “como una escenificación del debate político de la época” (Minguzzi, 1999, p.6).

\section{El ensayo de interpretación}

Surgido en gran parte como respuesta a un positivismo finisecular en crisis, eurocéntrico y de mira ya visualizada como estrecha, la ensayística de interpretación argentina, con todas sus contradicciones, propuso desentrañar el significado de nuestra identidad y, por si ello fuera poco, proponer además programas de acción que pudieran promover la anhelada meta de nuestra misión histórica (Rivera, 1993).

Un texto precursor de este estilo es de 1888, "La tradición nacional" de J. V. Gonzalez. Si bien cronológicamente pertenece a la generación del 80, no lo es así ideológicamente, ya que anticipa la crítica al europeísmo y a la confianza transculturadora de esa generación; expresando también el reclamo por un modelo educativo autónomo que promueva la formación de una conciencia nacional.

En la década de 1930 tres obras muy representativas de este estilo son: "Radiografía de la pampa" de E. M. Estrada; "Historia de una pasión argentina" de Eduardo Mallea y "El hombre que está solo y espera" de Raul Scalabrini Ortiz.

Un breve comentario sobre esta última obra. "El hombre que esta solo y espera" es de 1931, cuando Scalabrini, que había apoyado el golpe del 30, se desencanta del gobierno de Uriburu. Este es un claro ejemplo de las vacilaciones y cambios de bando políticos de los hombres de aquella época, a menudo incomprensibles desde el presente. Así es que en 1932 se aleja del grupo de los Floridistas (Borges, Mallea, Girondo, Marechal, Macedonio Fernandez, etc.) para acercarse al de Boedo, al radicalismo, al Teatro del Pueblo.

El "espíritu de la tierra" que define en esta obra como un "arquetipo histórico, multitudinario, que asimiló una inmigración heterogénea", habla de un sujeto que ya no es el de la elite minoritaria, ni el intelectual dador de pautas de vida, ni es el hombre aislado. Es el hombre de la multitud, el hombre del pueblo, en el que se integra su pasado (en temporalidad, espacialidad y caracteres) y su fusión en el proceso inmigratorio. En una 
definición de humanismo particular, afirma que solo el pueblo tiene fe en el hombre. En esta obra aparece el reconocimiento del pueblo como sujeto, como protagonista de la historia (Scalabrini Ortiz, 1932). En su búsqueda (y retrato) del hombre de "Corrientes y Esmeralda" (típica esquina de Buenos Aires) analiza críticamente el dominante modelo económico de dependencia, siendo uno de sus más lúcidos detractores (sin obviar a autores como Roberto Arlt, quien a través de sus obras - como por ejemplo Lanzallamas - se coloca en el sitial de los escritores sociales más críticos de su época).

\section{Del sainete al grotesco}

El sainete se instala a fines del siglo XIX y comienzos del XX como un género "de manchas de barrio o arrabal, superficiales sátiras de amoríos y trifulcas en el patio, el altillo, la cortada, el atrio electoral..." (Spinelli. 1965, p.13). Esta expresión literaria, de origen azarzuelado, trabaja una narrativa costumbrista que permite leer ciertos consensos sobre las escenas sociales de la época. En tales escenas, el componente inmigratorio es protagonista. El sainete tiene una contracara en el grotesco. El proyecto liberal había formulado un llamamiento a todos los hombres del mundo bajo la promesa de la integración a partir de la propiedad de la tierra, promesa incumplida sin duda. Los efectos, marginación y fracaso, van a tener expresión en el género del grotesco que se caracteriza por el individualismo; es decir, la pérdida de la referencia social que era propia del sainete es trocada en ahondamiento psicológico en el grotesco.

En la evolución entre los dos géneros literarios se detecta un urbanismo temático progresivo, explicitando los fenómenos de aglomeración urbana, ya en generación de hijos de inmigrantes, sintetizando "el circuito estancia-chacra-arrabal-centro en su verificación de la tierra prometida y bloqueada" (Viñas, 1973, p.29). Ya en los gobiernos de Irigoyen, con su espectro político de corte nacional y popular (con las reservas que impone el reformismo a esta afirmación) y con la proliferación de una clase media resultante del mismo incumplimiento de la promesa al inmigrante, las producciones literarias y teatrales van a venir a polarizar los nacionalismos aristocráticos y esta nueva congregación social emergente.
Al decir de Viñas, la generación de esta legítima cultura comunitaria será obstaculizada por las elites tradicionales a partir de 1930 y se definirá en la imposibilidad de las nuevas clases para reivindicarla. Así, para este autor, "el grotesco simboliza al inmigrante congelado por el conjuro de la elite tradicional" (p.123).

Hemos querido presentar, sucintamente, ejemplificando en algunas manifestaciones del movimiento cultural argentino de principios del siglo $\mathrm{XX}$, la generación, presencia y aborto de concepciones psicosociales en Argentina. Son expresiones discursivas de esa inmensa mayoría que, en el proceso de constitución de una nación que le era ajena, intentó perfilar, desde su misma heterogeneidad, rasgos identitários que les fueran propios.

En tal empresa, el forjamiento de proyectos comunitarios, o si se quiere comunidades, halló sus obstáculos en el seno del mismo proyecto que originó los emprendimientos. Fracaso del proyecto o necesidad de pervivencia para la clase que lo ideó? se preguntará un autor (Viñas, 1973).

A mediados del siglo XIX el esfuerzo de la generación del 37 fue formular ciertas características del ser nacional, no solamente para explicar hechos históricos sino para dar cuenta de un sujeto colectivo, y la educación se pensaba al servicio de la formación de una conciencia nacional homogénea. El positivismo reformula la herencia histórica en razón de la herencia biológica, y propone al individuo en lugar del sujeto colectivo (Klappenbach y Pavesi, 1994).

Es este marco referencial positivista en el que se genera, a la vez, una psicología científica, centrada en el estudio del individuo, el que da contexto para seguir indagando acerca de si lo que permitió la emergencia de una psicología científica en Argentina, es a la vez lo que obturó la posibilidad de interpretación de lo psíquico en términos de lo social.

\section{Referências}

Anderson Imbert, E. (1954). Historia de la literatura hispanoamericana. México: FCE.

Certeau M. de (1995). La toma de la palabra y otros escritos políticos. México: Universidad Iberoamericana. 
De La Camara, H. (1956). Lo romántico y los románticos. São Paulo: Facultad de Filosofía, Ciencias y Letras Municipal de Sorocaba.

Di Filippo, L. (1957). La gran contienda del romanticismo. Chilenos y Argentinos disputan en Chile. Buenos Aires: Castellví.

Ghiano, J. C. (1978). Relecturas argentinas. De Jose Hernandez a Alberto Girri. Buenos Aires: Ediciones del Mar de Solís.

Ghiano, J. C. (1960). 26 poetas argentinos (1810-1920). Buenos Aires: EUDEBA.

Giordano, C. (1968a). Los poetas sociales. Buenos Aires: CEAL.

Giordano, C. (1968b). Los escritores de Boedo. Buenos Aires: CEAL.

Giusti, R. (1954). Momentos y aspectos de la cultura argentina. Buenos Aires: Raigal.

Godio, J. (1987). El movimiento obrero (1870-1910). Buenos Aires: Legasa.

Godio, J. (1988). El movimiento obrero argentino (1910-1930), socialismo, sindicalismo y comunismo. Buenos Aires: Legasa.

Halperin Donghi. T. (1998). El espejo de la Historia. Problemas argentinos y perspectivas latinoamericanas. Buenos Aires: Sudamericana.

Isaacson, J. \& Urquía, C. (1963). 40 anos de poesía argentina. Buenos Aires: Aldaba.

Jitrik, N. (1970). La Revolución del 90. Buenos Aires: La Historia Popular, CEAL.

Klappenbach, H. \& Pavesi. P. (1994). Una historia de la psicología en Latinoamérica. Revista Latinoamericana de Psicología, 26, 3, pp.445-482.

Lobato, M. \& Zuriano, J. (2000). Los trabajadores en la era del progreso. In Nueva Historia Argentina. Buenos Aires: Sudemericana.

Minguzzi. A. (Comp.). (1999). La novela semanal (1917-1926). Buenos Aires: La Página.
Rivera, J. (Camp.). (1993). El ensayo de interpretación (1910-1930). Buenos Aires: CEAL.

Roig. A. (1994). El pensamiento latinoamericano y su aventura. Buenos Aires: CEAL.

Romero, J. L. (1994). Las ideologías de la cultura nacional y otros ensayos. Buenos Aires: CEAL.

Scalabrini Ortiz, R. (1932). El hombre que esta solo y espera. Buenos Aires: Anaconda.

Spinelll. S. (Comp.). (1965). Las de Barranco. Buenos Aires: Huemul.

Vilanova, A. (2002). El carácter argentino. Los primeros diagnósticos. Mar del Plata: UNMP.

Viñas. D. (1973). Grotesco, inmigración y fracaso. Buenos Aires: Corregidor. 


\section{“Ter" ou "fazer" o gênero: $O$ dilema das opções epistemológicas em Psicologia Social}

\section{Maria da Conceição Nogueira}

A categoria Gênero criada em meados dos anos 70 nas ciências sociais, tendo sido pensada no sentido da substituição do determinismo biológico associado ao termo sexo, cujos efeitos eram considerados nefastos para o conhecimento relativo $a$, para e com as mulheres, acabou, contudo, por não alterar substancialmente o "estatuto" das mulheres na psicologia e nas ciências sociais em geral, sendo inclusive considerada por muitas cientistas feministas, uma das categorias mais opressivas em psicologia (Nogueira, 2001a; 2001b).

A epistemologia experimental positivista tem sido considerada como uma das causas da manutenção de um conhecimento psicológico que, sob a aparência de uma pretensa neutralidade científica mantém a ordem estabelecida e por isso o estatuto menorizado das mulheres. Daí que o enquadramento teórico neste trabalho é essencialmente relativo às opções epistemológicas que condicionam as alternativas na psicologia, e na psicologia social.

As diferentes perspectivas teóricas críticas à psicologia tradicional, essencialmente positivista e realista, são frequentemente consideradas como pós-modernas, e apesar de haver alguma ambiguidade nesta designação, para efeitos práticos assim serão consideradas aqui. Também para a construção de uma psicologia diferente é necessário um referente epistemológico distinto. O pós-modernismo em geral, e as perspectivas construcionistas sociais e discursivas, da psicologia crítica e especificamente para este assunto em particular, da psicologia feminista crítica são fundamentais e apresentam se como epistemologicamente alternativas, devido à sua concepção acerca do que é o conhecimento.

Os debates iniciados pelo pós-modernismo, e as diferentes perspectivas que na psicologia são agora consideradas, têm implicações fundamentais para a forma como se conceptualiza o gênero. Depois de sistematizados os pressupostos destas perspectivas e apresentada a emergência de novas realidades e recursos de ação, analisar-se-á como o gênero pode ser concebido nestas novas abordagens, fazendo-se uma breve reflexão sobre a problemática do relativismo nestas perspectivas. Apresentar-se-á uma perspectiva pós-moderna (não radical), antiessencialista, construcionista social e discursiva do gênero: o gênero como uma construção social, um sistema de significados que se constrói, se organiza nas interações, e que governa o acesso ao poder e aos recursos. Terminamos apresentando as alternativas e estratégias necessárias a uma psicologia feminista, que tem pela frente um conjunto de questões que representam desafios estimulantes para o debate que urge continuar.

Existem diferentes argumentos a favor e contra a teorização pósmoderna feminista, mas o que é interessante notar é que o que está frequentemente em causa e em jogo nesses argumentos é o próprio estatuto do conhecimento, o que nós atribuímos acerca do ser humano ou mais especificamente ao que é ser "humano" e ser "mulher". Estas são implicações epistemológicas e estes debates epistemológicos têm implicações para a prática de uma psicologia feminista (Hepbur, 2003).

Ter ou fazer gênero são por isso duas possibilidades antagônicas que pressupõem posicionamentos epistemológicos distintos e por isso, duas formas de compreender o mundo.

Falar de conhecimento e assumi-la como algo de pertença individual tem sido a marca das ciências sociais e da psicologia desde os seus primórdios. No entanto, existem no presente, maneiras diferentes e antagônicas de considerar o conhecimento. O relativismo e as teorias pósmodernas do conhecimento veem desafiar o positivismo e o realismo enquanto posições epistemológicas para as ciências sociais (Hepburn, 2003). Na psicologia social o início deste movimento para posições alternativas relativas ao conhecimento começou com a designada "crise da psicologia social" nos anos 60 (Gergen, 1985; Jesuíno, 1993; Soczka, 1993), especificamente ao processo de descontentamento com o programa empiricista positivista da acumulação de conhecimento (Gergen, 1994). Crise ao nível epistemológico devido à pressuposição epistemológica de que o "indivíduo está no centro de todas as coisas" e por isso deve ser a principal unidade de pesquisa e análise (Augoustinos \& Walker, 1995; Pepitone, 1981). Esta individualização da psicologia social é largamente atribuída à junção das forças da experimentação e do positivismo que acabaram por dominar a disciplina, mascarando-a de uma respeitabilidade científica. Segundo Farr (1989), foram essas forças que levaram também à 
diminuição do interesse pelos fenômenos coletivos que tinham interessado os primeiros psicólogos como Wundt e Ross. ${ }^{1}$ Mas este desencanto, mais de epistemologia do que de confiança (Augoustinos \& Walker, 1995) terá tido poucos frutos, já que segundo Gergen (1994) os psicólogos sociais rapidamente saíram do descontentamento e voltaram ao quotidiano, continuando a fazer as suas pesquisas habituais, de forma que o conteúdo das questões nunca foi devidamente debatido.

No entanto, nas duas últimas décadas, começou a surgir uma segunda cultura acadêmica, variada nas origens mas unida no cepticismo face ao projeto empiricista para as ciências sociais e humanas. Especificamente na psicologia a visão do conhecimento como algo de pertença individual. é colocada em questão por formas alternativas de concepção do conhecimento (Hepburn, 2003), sendo o pós-modernismo, o movimento intelectual impulsionador desse criticismo face à modernidade (Burr, 2003).

O pós-modernismo, enquanto movimento intelectual geral, coloca desafios sem fim, rejeita suposições epistemológicas, refuta convenções metodológicas, resiste às pretensões do conhecimento, obscurece todas as formas de verdade. Tem versões mais radicais e outras mais moderadas, mas quer umas quer outras, representam um grande desafio para o conhecimento estabelecido no século XX (Rosenau, 1992). Como diz Jane Flax (1990) "algo se está a passar", já que um conjunto de alterações cultural tem mudado significativamente as nossas condições de vida, mudanças que necessitam ser nomeadas, descritas e compreendidas.

De uma forma geral, e independentemente da psicologia enquanto ciência, o pós-modernismo representa o questionar e a rejeição dos pressupostos fundamentais do modernismo, o movimento intelectual que o precedeu, tendo incorporado muitas das ideias intelectuais e artísticas que tinham surgido de forma desconexa desde o tempo do Iluminismo² (Burr,

${ }^{1}$ Esses psicólogos acreditavam que fenômenos culturais como a linguagem, os mitos, a religião e o nacionalismo, por exemplo, não podiam ser reduzidos a um nível de análise individual. Wundt acreditava mesmo que esses fenômenos não podiam ser adequadamente estudados pela tradição experimental.

${ }_{2} \mathrm{O}$ projeto Iluminista procurava a verdade, a compreensão da verdadeira natureza da realidade através da aplicação correta da razão e da racionalidade, sendo a ciência e os
1995). Rejeita as ideias de verdade última, de estruturalismo (a ideia de que o mundo como o vemos é o resultado de estruturas escondidas), de que o mundo possa ser compreendido em termos de grandes teorias ou metanarrativas (Lyotard, 1989) e ao mesmo tempo enfatiza a coexistência de uma multiplicidade e variedade de formas de vida dependentes das situações, muitas vezes referindo-se a pluralismo (Smart, 1993). Rejeita também a noção de que, através da aplicação de uma grande teoria ou metanarrativa, a mudança social dependa da descoberta, e posterior alteração, das estruturas subjacentes da vida social. A própria palavra "descobrir" pressupõe uma realidade estável e existente que pode ser revelada através da observação e da análise (Burr, 1995).

Para Ibañez (1994) na psicologia é o Construcionismo Social a escola que melhor se adequa ao pensamento pós-moderno. Pode considerarse o Construcionismo Social um uma orientação teórica resultante dos posicionamentos alternativos críticos e radicais desenvolvidos essencialmente nos EUA e na Inglaterra nos últimos 20 anos e que pode incluir perspectivas como a "Psicologia Crítica", a "Psicologia Discursiva", a "Análise do Discurso" ou o "Pós-estruturalismo" (Burr, 2003).

Segundo Parker (1998) assiste-se a um interesse crescente nas perspectivas construcionistas sociais de uma forma geral e nas abordagens que localizam os fenômenos psicológicos no discurso, de uma forma particular (Gergen, 1985; Harré \& Gillett, 1994; Parker, 1992; Potter \& Wetherell, 1987). Este interesse parece representar um movimento reflexivo e crítico da psicologia social tradicional positivista, no sentido de uma valorização da construção social, histórica, cultural e politicamente comprometida da experiência humana. A atratividade destas novas perspectivas reside essencialmente nas suas promessas libertadoras, dado o seu criticismo face ao positivismo exacerbado da disciplina com o assumir do essencialismo psicológico (Burr, 1995; 1998b). Assumir a construção social dos fatos psicológicos através de meios humanos torna possível imaginar uma reconstrução dos mesmos de formas mais atrativas e

indivíduos (em vez de Deus) o foco das questões da verdade e da moralidade. Esta procura da verdade baseava-se frequentemente na ideia da existência de regras ou estruturas profundas e enraizadas, que um método rigoroso e "correto" possibilitaria descobrir (Burr, 2003). 
libertadoras, e a um nível social amplo (Burr, 1998b). Esta ideia não implica assumir uma possibilidade ilimitada de alternativas, nem uma simplificação na decisão de dispensar discursos opressores. Contudo, parece tornar possível pensar, não só em indivíduos que reconstroem aspectos de si próprios, mas também no repensar de um conjunto das categorias sociais como o gênero, a sexualidade, a raça, a deficiência ou a doença (idem, 1998b).

O Construcionismo Social oferece também uma leitura crítica da própria psicologia (Burr, 1998b), que se tem esforçado arduamente por se proclamar como apolítica (Rose, 1990). Esta proclamação de neutralidade política é em si mesma altamente comprometedora do ponto de vista ideológico e político, precisamente porque acaba por legitimar as práticas socais que poderiam ser questionáveis, porque as representa como derivando de fatos psicológicos ou sociais livres de valor (value-free). $\mathrm{O}$ Construcionismo Social questiona radicalmente esta ideia de fatos objetivos, ao mesmo tempo que caracteriza a disciplina e a prática psicológica como parciais, dominadas por valores e movidas por direitos adquiridos implícitos.

Apesar do próprio Construcionismo Social ter sido influenciado por outras disciplinas como a filosofia, a sociologia e a linguística sendo por isso multidisciplinar, é um termo quase exclusivo da psicologia. Como refere Danziger (1997) o Construcionismo Social é uma das áreas atuais da psicologia onde os autores se misturam: psicólogos associam-se a sociólogos, antropólogos, filósofos, etc. Existem ligações claras em algumas partes, mas será difícil que dois pesquisadores partilhem exatamente o mesmo conjunto de preocupações e de assunções básicas. Ás vezes as ligações são mesmo muito superficiais já que existem autores que utilizam os mesmos termos de formas divergentes.

No entanto, apesar de não existir uma única definição de Construcionismo Social adequada para todos os autores, poder-se-á assumir que existem características partilhadas, algo em comum, ligandoos uma espécie de "parecença familiar" (Burr, 1995). Assim, pode-se livremente classificar de construcionista social qualquer abordagem que tenha na base um, ou mais, dos pressupostos fundamentais para uma ciência construcionista social (Burr, 1995; 2003; Nogueira, 2001a; 2001d).
Posição crítica face ao conhecimento fornecido como "verdade"

O Construcionismo Social insiste que se tenha uma posição crítica face ao conhecimento disponível, às observações objetivas do mundo como sendo de "natureza" individual e não enviesadas. Surge como oposição ao positivismo e ao empiricismo nas ciências sociais tradicionais, a suposição de que a natureza do mundo pode ser revelada através da observação, e que aquilo que "existe" é aquilo que se percebe que existe.

Sugere que as categorias com as quais se apreende o mundo não se referem necessariamente a divisões "reais". Um exemplo radical desta questão diz respeito ao gênero e ao sexo. As observações do mundo sugerem que existem duas categorias de seres humanos - homens e mulheres. Gergen (1992) questiona a necessidade de distinção entre masculinidade e feminilidade por não refletirem nenhuma realidade palpável e independente. Embora se tenha bem claro que existem diferenças nos órgãos de reprodução que estão presentes em muitas espécies, deve-se questionar o porquê dessa distinção ter sido sempre tão importante, para que o conjunto das categorias da personalidade se baseasse nela (homem e mulher) (Burr, 1995). Para além disso, tornamonos cada vez mais conscientes do caráter "sombrio" destas categorias, quando se presencia cada vez mais, práticas de cirurgias para mudança de sexo e o debate acerca de como classificar (sem ambiguidade) as pessoas em homens e mulheres (Burr, 2003). A masculinidade e feminilidade numa dada cultura, categorias aparentemente "naturais" estão inevitavelmente ligadas ao gênero, de modo que o que representa ser homem ou mulher está construído sobre essa prescrição. ${ }^{3}$

\section{Especificidade histórica e cultural}

Os termos e as formas pelas quais se consegue compreender o mundo e cada um individualmente são artefatos sociais, produtos de interrelações entre as pessoas, com especificidade histórica e cultural.

\footnotetext{
${ }^{3}$ De forma absurda poderíamos igualmente dividir os seres humanos em altos ou baixos, por exemplo, e esta ser uma categoria tão central para as nossas vidas como é a categoria de sexo.
} 
Para os construcionistas, as descrições e explicações não são nem motivadas pelo mundo como ele é, nem o resultado inabalável, firme ou estável de propensões estruturais genéticas dentro do indivíduo. Pelo contrário, elas são o resultado de uma ação humana coordenada. As palavras apenas possuem significado dentro de um contexto relacional. Elas são o resultado não da ação e reação individual, mas de ação conjunta, da coação (Shotter, 1993; Shotter \& Gergen, 1989). Se, e como diz Bakhtin (1981. Cito Gergen, 1994), as palavras são inerentemente interindividuais, isto quer dizer que para conseguir inteligibilidade é necessário participar num padrão-relacional reiterativo ou, se suficientemente expandido, numa tradição.

Segundo o Construcionismo Social as formas como se compreende normalmente o mundo, as categorias e os conceitos que se utilizam são específicos de um tempo histórico e cultural (Burr, 1995; Gergen, 1985). Quer se compreenda o mundo em termos de homem ou mulher, vida urbana ou vida rural, passado ou futuro, tudo isso depende do "onde" e do "quando" do mundo em que se vive. ${ }^{4} \mathrm{O}$ conhecimento é relativo e dependente do tempo e da cultura, isto é, não só é específico a culturas particulares e períodos da história, como também é produto dessa cultura e história e dependente dos arranjos prevalecentes quer econômicos, quer sociais (Burr, 1995; 2003). As formas particulares de conhecimento que abundam numa determinada cultura são artefatos dela e não se deve assumir que determinadas formas de compreensão são necessariamente melhores (em termos de estarem mais próximas da verdade) do que outras.

\section{O conhecimento é sustentado/mantido por processos sociais}

Determinada descrição do mundo ou do self é sustentada ao longo do tempo, não por validade objetiva, mas devido às vicissitudes do processo social.

\footnotetext{
${ }^{4}$ Por exemplo, a noção de infância teve mudanças importantes ao longo dos séculos. O que se considera hoje "natural" que uma criança faça mudou muito, assim como mudou aquilo que os pais esperam dela. Só muito recentemente as crianças deixaram de ser consideradas como adultos pequenos. A autora refere que não é necessário recuar muito (basta até Dickens) para nos apercebermos que a ideia de uma criança inocente e a precisar de proteção do adulto é realmente uma noção nova.
}

O conhecimento do mundo e as formas comuns de o compreender não derivam da natureza do próprio mundo em si mesmo (Burr, 1995). O conhecimento do mundo não provindo da natureza dele próprio, provém das construções das pessoas acerca dele (Burr, 2003). É através das interações diárias entre as pessoas no decurso da vida social que as nossas versões do conhecimento são fabricadas. Por isso, todo o tipo de interação social e particularmente, a linguagem, é de grande interesse para os construcionistas sociais (Burr, 1995). Os acontecimentos/acasos entre as pessoas no decurso da sua vida de todos os dias, são encarados como práticas durante as quais as versões partilhadas de conhecimento são construídas. O que se pensa ser a "verdade" (que varia quer histórica, quer culturalmente), isto é, as ideias correntes e aceites de compreensão do mundo, são apenas um produto, não da observação objetiva do mundo, mas do processo social e das interações nas quais as pessoas estão constantemente envolvidas.

Como o conhecimento e a ação social "caminham" juntos, o entendimento "negociado" do mundo pode tomar uma grande variedade de formas, e por isso pode-se falar de numerosas e possíveis "construções sociais", onde cada construção pode convidar a uma determinada ação.

\section{O significado da linguagem deriva do seu modo de funcionamento dentro dos padrões de relacionamento}

A linguagem é algo de único nos seres humanos. Os animais comunicam entre si através de sons, marcas, gestos e posturas para assinalar perigo, ocupação do território, paradas sexuais, etc. Apesar desses comportamentos terem um significado que suscita respostas dos outros animais (luta, fuga, cópula, etc.), este significado é sempre fixo e estável e esta é a principal diferença em relação à linguagem humana (Burr, 1995).

$O$ papel que a linguagem desempenha na perspectiva do Construcionismo Social é radicalmente diferente do que é assumido pela psicologia tradicional. A psicologia tradicional assume que a linguagem representa uma expressão fácil de compreensão do pensamento e não que aquela é uma pré-condição deste. Pensa-se na linguagem como um conjunto de "etiquetas" que podem ser escolhidas de forma a melhor descrever os estados internos (pensamentos e sentimentos). Naquela 
perspectiva, a natureza da pessoa surge em primeiro lugar, sendo o papel da linguagem o de encontrar a forma de expressar essa natureza, ou seja, as pessoas usam a linguagem para dar expressão a algo já existente em si mesmas ou no mundo.

A ideia tradicional e assumida pelo senso comum da "linguagem como transparência" é questionada pelo Construcionismo Social, que não considera a linguagem um meio claro e puro através do qual os pensamentos e sentimentos se podem tornar acessíveis aos outros, ou uma espécie de "janela sem irregularidades no vidro" que possam distorcer a visão através dela. O uso da linguagem é uma forma de ação tendo por isso um caráter "performativo". Quando as pessoas falam umas com as outras, o mundo é construído e por isso a linguagem não é apenas um veículo passivo para os pensamentos e emoções (Burr, 1995). A pedra base do Construcionismo Social é a insistência sobre a natureza partilhada dos códigos da linguagem, em constante mudança e variando nos seus significados em função dos contextos.

Se a forma de compreender o mundo não provém de nenhuma realidade objetiva, (antes das pessoas passadas ou presentes), isso representa que os indivíduos nascem num mundo onde já existem os campos conceptuais e as categorias usadas pelas pessoas numa dada cultura. As pessoas adquirem esses conceitos e essas categorias pelo uso da linguagem, que todos os dias se reproduz na cultura. Isto é, a forma como as pessoas pensam, os conceitos e as categorias que lhes permitem um campo de significados são fornecidos pela sua linguagem.

Para Hoffman (1992) os teóricos construcionistas sociais acreditam que as ideias, os conceitos e as memórias surgem do intercâmbio social e são midiatizadas pela linguagem. Todo o conhecimento desenvolve-se entre as pessoas, no mundo quotidiano.

\section{Conhecimento e ação social caminham em paralelo}

Avaliar as formas de discurso existentes é ao mesmo tempo avaliar padrões de vida social e cultural. Estes conhecimentos ou entendimentos negociados entre as pessoas podem tomar uma variedade de formas e podemos por isso falar de possíveis e numerosas construções sociais do mundo. Mas cada construção pode convidar a uma forma particular de ação
(Burr, 2003). Por exemplo, ver o alcoolismo como algo da inteira responsabilidade individual implicaria o aprisionamento das pessoas que sob o seu efeito provocassem problemas. Vê-lo (ao alcoolismo) como uma forma de doença implica tratamento médico porque se pensa que as pessoas sob o efeito do álcool não são responsáveis pelas suas ações. A ação social apropriada para compreender o alcoolismo desta forma é oferecer tratamento médico e psicológico e não prisão. Descrições ou construções do mundo sustentam assim padrões da ação social e excluem outros. As nossas construções do mundo são por isso ligadas às relações de poder porque têm implicações para aquilo que é considerado permitido para determinadas pessoas fazerem e para fazerem umas com as outras.

Concluindo, o Construcionismo Social pretende sintetizar de várias formas todas as críticas já apresentadas, e mover-se para além da crítica, no sentido de uma descrição mais positiva do potencial científico. Sendo o conhecimento não o que se tem, mas o que se faz junto com outras pessoas, o objetivo da pesquisa construcionista desloca-se da natureza das pessoas ou da sociedade para as interações e para as práticas sociais daí resultantes (Gergen, 1994). Segundo Burr (1995), é essencialmente o seu caráter antiessencialista, antirrealista, a pressuposição da linguagem como précondição para o pensamento e como forma de ação social e, o seu foco na interação e nas práticas sociais aliada à perspectiva do conhecimento como especificamente histórico e cultural, que o diferencia da abordagem da psicologia mais tradicional.

Questionando os pressupostos do essencialismo e do humanismo a teoria construcionista social moveu o centro da atenção da pessoa para o domínio social. A psicologia nesta perspectiva torna-se o estudo do ser socialmente construído, o produto de discursos historicamente e culturalmente contingentes, discursos que trazem consigo uma rede complexa de relações de poder. A pessoa fica como que "encaixada" num sistema histórico, social e político do qual não pode ser retirada e estudada de forma independente.

Esta "viragem para a linguagem" representada pela Psicologia Discursiva (Potter e Wetherell, 1987) e pela Analise Foucaultiana do Discurso (Parker, 1998), com o foco de atenção no discurso, tem facilitado uma descrição histórica do conhecimento psicológico (a forma como a psicologia está construída na cultura), uma crítica à prática psicológica 
desafiando as suas proclamações de verdade, assim como uma transformação nas perspectivas metodológicas.

A popularidade da Análise do Discurso também lhe advém da possibilidade dos seus utensílios de pesquisa poderem ser usados para moldar uma prática política. A Análise do Discurso é usada para comentar os processos sociais que participam na manutenção das estruturas de opressão. Na psicologia, esta abordagem tem sido utilizada, por exemplo, para trabalhar o discurso racista (Potter e Wetherell, 1992), as práticas da maternidade (Llombart, 1995; Fidalgo, 2000), o discurso de mulheres em posições de poder (Nogueira, 1997) e todas as questões associadas ao feminismo (Wilkinson e Kitzinger, 1995).

É cada vez mais necessária a introdução da dimensão política numa disciplina que, como a psicologia social, deve responder ao pedido de relevância que provém dos sectores afetados pelas contradições existentes na ordem social (Oill, 1995; Llombart, 1995). Não sendo a única via, a Análise do Discurso pode servir este objetivo. A Análise do Discurso ao permitir um aprofundamento da compreensão das estratégias discursivas que moldam as formas distintas de construção do meio social, ao colocá-las abertamente sob crítica, acaba por facilitar os processos de transformação, não os reproduzindo.

Avaliar os efeitos de um determinado discurso (de entre uma pluralidade de efeitos possíveis) constitui uma responsabilidade éticopolítica. ${ }^{5}$ Esta posição pode apenas ser exercida se se tiver um compromisso de crítica face à ordem social dominante e não apenas numa crítica metodológica. Enfatizar as discussões e argumentações meramente metodológicas, sem um mínimo de crítica social diminui a possível repercussão pragmática dessa análise, acabando por manter apenas a ordem já estabelecida (Gill, 1995).

A viragem para perspectivas construcionistas e discursivas parece indicar, segundo Ibañez (1996), que a psicologia começa finalmente a abandonar algumas das "ingenuidades" herdadas da modernidade,

\footnotetext{
${ }^{5}$ Por exemplo, o poder político e o status quo são sustentados pela natureza contraditória e retórica dos discursos ideológicos .A força de uma posição ou perspectiva política não tem que ver com a coerência interna (Hepbur, 2003).
}

nomeadamente a crença na existência de uma "realidade" independente do nosso modo de acesso a ela e acreditar que a objetividade constitui um modo privilegiado de "ver a realidade tal como é". Como consequência destas ingenuidades e essencialmente da adesão acrítica ao mito da objetividade, a psicologia enquanto ciência acaba por se restringir ao papel de simples cronista da realidade, desvinculando-se de toda a responsabilidade e compromisso. Acreditando na existência de uma realidade face à qual podem existir modos privilegiados de acesso, a psicologia acabou por aderir a uma ideologia que confere à razão cientifica um estatuto a-histórico, afirmando-se como uma potente retórica da verdade. "No entanto, Ibañez não propõe que vivamos num mundo sem verdades; sugere apenas que elas são sempre específicas e construídas a partir de convenções pautadas por critérios de coerência, utilidade, inteligibilidade, moralidade, o que quer dizer que são adequadas às finalidades que coletivamente são designadas como relevantes" (Spink e Freeza, 1999, pp.29, 30).

No entanto, depois dos primeiros anos de entusiasmo geral pelas perspectivas construcionistas e discursivas, começou progressivamente a assistir-se ao tomar de posições por vezes distintas, dentro destas novas abordagens, que justificam debate e esclarecimentos (Burr, 2003; Parker, 1998). Apesar de existirem várias possibilidades de pequenas diferenças e vários debates, parece-nos que uma diferença fundamental diz respeito às opções entre visões discursivas distintas (Burr, 2003), o grande debate se refere à problemática do relativismo (Burr, 1998b; Gill, 1995; Parker, 1998), mas uma asserção basilar é principalmente o anti-essencialismo.

\section{Uma diferença: micro e macro construcionismo social}

Disse-se anteriormente que o Construcionismo Social abarcava em si perspectivas comuns do ponto de vista epistemológico, mas distintas parcialmente em termos teóricos e metodológicos. Era o caso da Psicologia Discursiva versus Análise Foucaultiana do Discurso (frequentemente também designado por Análise Crítica do Discurso (Wetherell, Taylor e Yates, 2001; Wood e Kroeger, 2000), o que equivale a versões mais light e dark (Danzinger, 1997) ou micro e macro (Burr, 2003) Construcionismo Social. 
A preocupação da Psicologia Discursiva consiste em estudar como as pessoas usam a linguagem nas suas interações quotidianas, os seus "discursos" uns com os outros e como são eficazes ao usar as suas competências linguísticas para construir versões de acontecimentos que por sua vez têm implicações poderosas para quem interage com elas. Tem a ver com as funções performativas da linguagem. Muito abreviadamente poderse-á dizer que o Micro Construcionismo Social focaliza a força construtiva na interação entre as pessoas, enfatizando o processo de contínua construção do significado no diálogo quotidiano, não privilegiando particularmente as questões de poder. A construção social faz-se no discurso de todos os dias entre as pessoas em interação. As múltiplas versões do mundo estão potencialmente disponíveis através deste trabalho discursivo e construtivo e não há nenhuma possibilidade de alguém dizer que umas são mais reais que outras. A única realidade a que temos acesso é a esse texto e não temos possibilidade de reclamar um mundo real que existe para além dele. Assim, todas as proclamações de verdade são indeterminadas, promovem um cepticismo relativo ao conhecimento dado como verdade. Se as questões de poder são aqui referidas, são encaradas como um efeito do discurso, um efeito do fato de se ter "autorização a ter voz" nas interações (Gergen, 1994). Nos EUA, os autores mais conhecidos nesta perspectiva são o próprio Kenneth Gergen e John Shotter. Gergen focaliza-se na força construtiva da interação, enfatizando como o pensamento individual e a ação individual são atravessados pela força relacional. Shotter (1995) focaliza-se na análise conversacional, enfatizando o processo interpessoal e de caracter dinâmico da construção. a que chama de joint action. Os autores ingleses como Potter, Edwards, Ahsmore, Wetherell, Harré, frequentemente denominadas como o grupo de Loughborough, são os mais próximos desta perspectiva.

A Análise Foucaultiana do Discurso enfatiza o trabalho construtivo que as pessoas realizam para construir versões dos acontecimentos. Baseiase essencialmente no trabalho do filósofo pós-estruturalista francês Michel Foucault. Preocupa se como os sujeitos, vistos individualmente, se constroem através das estruturas da linguagem e através da ideologia. usando discursos (escrito, imagem visual, oral) que estão disponíveis para ser lidos, vistos ou ouvidos. O significado de um discurso é algo sempre indeterminado, em aberto e interacional. A "desconstrução. sendo a análise critica dos discursos existentes" (Denzin, 1995. p.52) preocupa-se em identificar os efeitos ideológicos e o poder dos discursos. Foucault argumenta que a maneira como as pessoas falam e pensam acerca das coisas - a maneira como estas são extensamente representadas na sociedade - trazem implicações para a maneira como as pessoas são tratadas. As nossas representações trazem consigo formas particulares de relações de poder. As nossas maneiras de falar e de representar o mundo através de textos escritos ou de imagens, por exemplo, constituem os discursos através dos quais experienciamos o mundo. Esta perspectiva enfatiza o poder construtivo da linguagem, mas vê-a derivada de, ou pelo menos relacionada, com estruturas sociais e materiais, relações sociais e práticas institucionalizadas. A concepção de poder é central — representa o cerne desta perspectiva.

Esta abordagem, influenciada por Foucault, influencia o trabalho de Parker (1998) e de Willig (1998) na Inglaterra e de Rose (1990) nos EUA, este último, por exemplo, tem mostrado como noções de ciência ou de indivíduo são socialmente construídas. Esta abordagem também tem sido usada por pesquisadoras feministas como Hollway (1984, 1989), Kitzinger (1987. 1989). Burman (1990) e Ussher (2000). Como o foco desta abordagem reside nas questões de poder, o Construcionismo Social Macro está especialmente interessado em analisar várias formas de desigualdades sociais, tais como o gênero, a raça e a etnicidade, deficiência ou doença mental, com a perspectiva de transformar a pesquisa e as práticas.

Enquanto a autora Viven Burr (2003) pensa que a visão Macro e Micro não deveriam ser vistas como mutuamente exclusivas, Danzinger (1997) sugere que é precisamente neste ponto que é necessária mais reflexão. A autora Wetherell (1998) também apela a uma síntese das duas versões da Análise do Discurso, argumentando que temos de ter em conta, quer a natureza situada e localizada dos eventos assim como as práticas institucionalizadas e as estruturas sociais dentro das quais esses eventos são construídos.

\section{Um debate: realismo versus relativismo}

À primeira vista e analisados os princípios construcionistas sociais, este deveria ser um debate ultrapassado. Enquanto o realismo supõe um mundo externo que existe independente das nossas representações sobre 
ele e passível de ser conhecido, o relativismo, pelo contrário, argumenta que, mesmo que essa realidade exista, ela não nos está acessível. As únicas "coisas" às quais temos acesso são as nossas várias representações do mundo e essas não podem ser julgadas para avaliar da "realidade" ou da "exatidão" ou da "verdade".

Todo o conhecimento deriva do fato de se olhar o mundo de uma ou outra perspectiva e em função de uns interesses em detrimento de outros. E é nesta questão que residem as questões que suscitam o debate. O fato de muitos autores assumirem um relativismo radical sinônimo de "tudo igual", "tudo o mesmo", implica de imediato que qualquer posicionamento, envolvimento político ou ação (Willig, 1999a) podem ficar comprometidas e, consequentemente, todo o potencial de uma psicologia crítica emancipadora (Parker, 1998). Em face a este dilema alguns autores advogam o assumir de um realismo crítico (Bhaskar, 1986, cit. in Parker, 1992), enquanto outros preferem falar de relativismo crítico (Parker, 1998), isto é, criticando o realismo, mas não assumindo um relativismo radical, possibilita-se a construção de alternativas emancipadoras.

Este debate tão atual entre realismo/relativismo parece ser a manifestação de uma dicotomia construída que está a ser possivelmente mais limitativa que interessante (Burr, 1998a). Muitos dos mal entendidos e do conflito desgastante à volta desta dicotomia tem a ver provavelmente com algumas ambiguidades relativas àquilo que se considera a realidade e as suas diferentes dimensões. Uma forma de ultrapassar o problema poderá ser assumir que as coisas são construídas socialmente e ao mesmo tempo "reais" (Brown, Pujol e Curt, 1998). Apesar do aparente simplismo e pragmatismo, perigo maior será o Construcionismo Social e a Análise do Discurso, receosos de reificar determinadas construções sobre outras, acabarem por ficar meros "observadores e comentadores" deixando a ação para outros (Burr, 1998a).

Segundo Willig (1998) a psicologia enquanto disciplina não pode dizer que não age, já que tudo está em constante movimento e a inatividade é, em si mesma, uma forma de ação. Apenas podemos estar a favor ou contra, aceitar ou resistir às posições que os discursos nos oferecem, não nos podemos abster; nessa situação, por defeito, estamos de acordo com o status quo, legitimando-o. Esta autora enfatiza o poder da Análise Crítica do Discurso, precisamente pela possibilidade de mostrar que tudo pode ser diferente. Burr (1998), na mesma linha de Willig, reafirma a responsabilidade de fazer recomendações para a ação, baseada em valores, mas usando de grande reflexividade e crítica. Esta perspectiva será defendida precisamente quando da apresentação destas abordagens para as questões do gênero.

Um posicionamento relativista crítico (apesar da coexistência de algumas divergências entre autores) poderá permitir uma abordagem mais reflexiva na psicologia, mais próxima das pesquisas radicais que pretendem situar os debates críticos no contexto mais amplo das ciências humanas (Parker, 1998).

\section{Uma asserção basilar: o anti-essencialismo}

Se o mundo social, incluindo a nós como pessoas, somos o produto dos processos sociais, então não existe nada "dado naturalmente" ou "determinado" quer no mundo quer nas pessoas. Não existem essências dentro das coisas ou das pessoas que as tornem no que são ou responsáveis por aquilo que são. Apesar do behaviorismo inserido na perspectiva de psicologia mais tradicional, possa concordar com tal, a Teoria dos Traços ou a Psicanálise, baseadas na ideia de algum conteúdo pré-determinado dentro das pessoas, é absolutamente antagônica. Daí que esta é uma asserção muito importante e radical. Frequentemente as pessoas pensam que o Construcionismo Social significa que o que nos envolve tem impacto na nossa psicologia ou mesmo que a nossa natureza é um produto de fatores ambientais incluindo sociais e não biológicos (perspectiva da socialização). Ambas estas perspectivas são essencialistas, já que veem as pessoas como tendo alguma natureza passível de definição e de descoberta, seja ela proveniente da biologia ou do meio ambiente. O essencialismo encurrala as pessoas dentro de personalidades e identidades que são limitadas e frequentemente patologizadas, o que por sua vez torna a psicologia uma prática ainda mais opressiva. 


\section{Abordagem construcionista social/discursiva crítica do gênero ${ }^{6}$}

Segundo Lígia Amâncio (1999) "apesar da já longa existência do conceito de gênero, as ciências sociais têm tido dificuldade em construir um modelo de análise teórico e consistente das relações entre os sexos que corresponda a uma verdadeira descentração epistemológica do dualismo associado ao sexo biológico" (p.2). Podemos questionar-nos como esta situação é possível passados mais de 30 anos desde que as cientistas sociais identificaram o gênero como uma dimensão de análise importante (Howard e Hollander, 1997; Wilkinson, 1997a; 1997b), com toda a produção científica consequente. Esta situação dá origem ao debate atual entre feministas relativamente ao que se pode compreender como verdade ou realidade acerca do gênero (Gergen e Davis, 1997). Frequentemente os estudantes têm dificuldade em aceitar o feminismo e muito menos, uma Psicologia Feminista (Hepburn, 2003). Contudo, ficam perplexos quando confrontados com as desigualdades e discriminações existentes há 20 ou 30 anos. E, provavelmente, daqui a trinta anos, novos estudantes admirar-seão com as desigualdades presentes, mesmo no mundo ocidental.

Mas assumindo, como assumimos, desigualdades de gênero na vida de todos os dias e frequentem ente de formas invisíveis, como as podemos estudar? E por que falar de uma Psicologia Feminista?

A psicologia tradicional tem funcionado frequentem ente ao longo dos tempos mais como domínio científico opressivo para as mulheres do que de libertação ou de criação de bem estar. A ausência das mulheres da ciência psicológica, a sua visão como desviantes da norma universal masculina, a construção de teorias que as vitimizam (a teoria do medo do sucesso, por exemplo), o grande aparato das diferenças sexuais, faz com que seja necessário a colocação de delimitação de um domínio que se dedique às desmistificações e à desconstrução das categorias opressivas como o gênero. Isto é, urge desconstruir a feminilidade e a masculinidade como categorias fundamentais (Wilkinson, 1997a; 1997b) que governam a vida social e psicológica, promovendo discursos alternativos.

${ }^{6}$ Algumas das ideias fundamentais apresentadas nesta parte do trabalho estão enunciadas no trabalho referenciado como Nogueira (2001b).
A distinção relativa a diferentes posicionamentos feministas nos estudos de gênero proposta por Sandra Harding, em 1986, surge como imprescindível para a compreensão desta ligação das teorias feministas a uma psicologia feminista (Nogueira, 200 I a; 200 I b). Esta autora descreve três tipos de posturas ou programas feministas: a perspectiva empiricista, a de "standpoint" feminista e a perspectiva pós-moderna.

O padrão tradicional, ainda predominante na Psicologia é o padrão empiricista (Gergen e Davis, 1997). Neste tipo de abordagem, as cientistas procuram estudar os acontecimentos, procurando recolher informação de forma objetiva e fiável, apresentando os resultados objetivamente. Apesar das psicólogas feministas nesta perspectiva terem demonstrado que, de todos os trabalhos relacionados com as diferenças sexuais, poucos podem ser considerados válidos já que parecem existir mais semelhanças entre os sexos do que diferenças, elas afirmam que só dentro do paradigma poderão demonstrar o contrário (Eagly, 1994; Halpern, 1994). Nesse sentido, advogam a continuação da cruzada empiricista, provando que não há diferenças, onde outros as encontram. Esta perspectiva é cada vez mais questionada, já que colocar as questões em termos de diferenças, mesmo partindo da premissa de que possivelmente não se encontrarão, implica assumir que se acredita que existem dois grupos distintos (homens e mulheres) que podem ser estudados como categorias universais e diferenciadas.

Uma alternativa importante à abordagem empiricista é identificada como uma posição de "standpoint feminista". Esta posição enfatiza o aumento do conhecimento como uma atividade pessoal onde pesquisador e sujeito estão em interação contínua, sendo indissociáveis das suas próprias experiências. Esta abordagem distancia-se da ênfase de procura de objetividade e neutralidade característica da abordagem empiricista (Kitzinger, 1990; Harding, 1986). Centralizam os estudos nas próprias mulheres, produzindo conhecimento que consideram verdadeiramente feminino porque exclusivamente centrado nas experiências particulares (Rose, 1990). Nos Estados Unidos o bem divulgado trabalho de Carol Gilligan é o expoente máximo característico desta posição. No seu livro clássico In a Different Voice (1982), a autora enfatiza a capacidade das mulheres de falarem sobre as suas próprias experiências, apresentando uma teoria alternativa do desenvolvimento moral. Muitas psicólogas aderentes 
desta perspectiva, ao estudarem as experiências individuais, como uma forma de enriquecer a Psicologia das mulheres, pretendiam indiretamente desafiar a validade tradicional dos métodos científicos. No entanto, ao rejeitarem a negatividade associada aos estereótipos sobre as mulheres, estas cientistas acabaram frequentemente por celebrar a natureza especial das mulheres e, por isso, enfatizar mais do que negar importantes diferenças entre os sexos (Hartsock, 1990).

Antes de se apresentar a terceira abordagem no estudo do gênero que Sandra Harding designa por pós-moderna e que na psicologia é protagonizada pelo Construcionismo Social (Análise do Discurso ou mesmo Psicologia Crítica em função de diferences nuances dentro de mesma postura epistemológica), pareceu-nos importante discutir em primeiro lugar o modo como se pode conceber um feminismo pós-moderno e em segundo lugar, as críticas às duas abordagens anteriores. Estas breves apresentações constituem o pano de fundo para a compreensão da terceira e última abordagem enfatizada neste artigo.

A teoria pós-moderna feminista deve pressupor múltiplas categorias, imbuídas de temporalidade, não-universalistas (Flax, 1990; Fraser e Nicholson, 1990; Haraway, 1990). Os métodos devem ser mais comparativos, atentos às mudanças e aos contrastes, em vez de procurarem leis; devem evitar o conforto metafísico de um único método feminista ou de uma epistemologia feminista. Finalmente, a teoria pós-moderna feminista deve substituir as noções unitárias de mulher e de identidade de gênero feminina, por concepções construídas, complexas e plurais de identidade social, tratando o gênero como algo relevante e importante entre outras coisas, atendendo também à etnicidade, à idade e à orientação sexual (Haraway, 1990).

A grande vantagem deste tipo de teoria reside na sua utilidade para a prática política feminista contemporânea, já que esta é cada vez mais uma questão de alianças, e não uma unidade à volta da universalidade partilhada de interesses ou identidade. Reconhecer a diversidade das necessidades e experiências das mulheres significa não aceitar soluções únicas e universais. Nenhuma solução para questões como o cuidar das crianças, a segurança social etc., pode ser simples e única, adequada a todas as circunstâncias, já que nem todas as mulheres partilham dos mesmos interesses e enfrentam os mesmos "inimigos". Neste sentido, pode-se falar do termo "plural" como prática de feminismo (Fraser e Nicholson, 1990; Kappeli, 1991). Segundo Flax (1990), o feminismo pós-moderno pode contribuir para uma perspectiva pluralista, já que o modelo monolítico de racionalidade, autenticidade e verdade foi sempre baseado numa forma (masculina) de conhecimento.

Como referido atrás, para melhor se compreender o gênero numa perspectiva construcionista social (aquela que se insere na perspectiva pósmoderna apresentada por Sandra Harding) é importante ter presente as críticas fundamentais às duas abordagens anteriores (empiricista e de 'standpoint' feminista), já que esta se apresenta como radicalmente distinta.

Segundo Bohan (1997) e Howard e Hollander (1997) as duas perspectivas são principalmente essencialistas, isto é concetualizam o gênero como característica permanente e estável nos indivíduos (Nogueira, 200 Ia; 2001 b). O essencialismo não implica necessariamente num determinismo biológico ou numa ênfase do biológico para a explicação das especificidades do gênero (embora historicamente o determinismo biológico tenha sido uma forma de essencialismo referente ao gênero). É o fato de se assumir a existência de qualidades ou características de e nos indivíduos e não as suas origens (biológicas ou sociais) que define o essencialismo (Crawford, 1995). Os modelos essencialistas assumem o gênero em termos de atributos internos e persistentes, mas separados das experiências de interação que se vão sucedendo nos contextos diários, sociopolíticos da vida (idem, 1995). Como refere Hare-Mustin e Marecek (1990a; 1990d), a reafirmação de qualidades essenciais negligencia a complexidade e o dinamismo do comportamento que se estabelece durante as relações sociais, reificando um jogo de diferenças que estão sempre em mudança, em dualismos estáticos exagerados (idem, 1990).

A distinção entre os termos sexo e gênero, sugerida e desenvolvida durante a segunda vaga do feminismo, foi uma tentativa (significativa) de separar o sexo - biológico, do social o gênero (Amâncio, 1994) e deste modo possibilitar a crítica social (Crawford, 1995). No entanto, a força cultural do essencialismo acabou por manter a distinção, dando lugar à confusão, inconsistência e problemas de terminologia. Isto é, novas diferenças sexuais, virtualmente idênticas às publicadas décadas atrás, começaram e são etiquetadas como diferenças de gênero. Estas novas diferenças são iguais às antigas, mas "vestidas" de outro modo, isto é, 
continuam a situar-se dentro dos indivíduos, descontextualizadas socialmente e rapidamente biologizadas. Ironicamente, uma pretensão feminista que visava teorizar a construção social da masculinidade e da feminilidade, é agora a mesma estratégia que a obscurece (idem, 1995).

A própria noção de Psicologia da Mulher é essencialista porque sugere que as mulheres (como grupo unitário) partilham uma psicologia (um conjunto de qualidades, traços e capacidades, inatas ou adquiridas) que, presumivelmente, lhes condiciona o comportamento (Hare-Mustin e Marecek, 1990d). Outra consequência importante é que quando os traços estão localizados nos indivíduos a responsabilidade da mudança fíca colocada nas pessoas e não na sociedade (Bohan, 1997).

$\mathrm{Na}$ psicologia, a perspectiva construcionista social do gênero pode assumir-se como aquela que se insere nas abordagens pós-modernas assumidas por Sandra Harding. Em contraste com uma perspectiva essencialista, o Construcionismo Social assume o gênero como uma construção social, um sistema de significados que se constrói e se organiza nas interações e que governa o acesso ao poder e aos recursos (Crawford, 1995; Denzin, 1995). Não é por isso um atributo individual, mas uma forma de dar sentido às transações: ele não existe nas pessoas, mas sim nas relações sociais.

Os processos relacionados com o gênero influenciam o comportamento, os pensamentos e os sentimentos dos indivíduos, afetam as interações sociais e ajudam a determinar a estrutura das instituições sociais (Crawford, 1995). Como o gênero é uma ideologia dentro da qual as diferentes narrativas são criadas, as distinções de gênero ocorrem disseminadamente na sociedade. $O$ discurso do gênero envolve a construção da masculinidade e da feminilidade como polos opostos e a essencialização das diferenças daí resultantes.

O Construcionismo Social (Gergen, 1982, 1994a), assim como a filosofia de tendência pós-modernista (Flax, 1990) reconhece a contradição como parte fundamental da realidade social e isso é consistente com a argumentação de que categorias importantes como o sexo e o gênero podem funcionar com definições distintas e em simultâneo numa situação particular. Diferentes participantes, ou mesmo e apenas um só indivíduo, podem, no decorrer de uma interação social, afirmar diferentes perspectivas de gênero, dependendo dos aspectos salientes das categorias no momento (Hare-Mustin \& Marecek, 1990a).

Nesta perspectiva, as pessoas desenvolvem os seus sentidos de self, nos e através dos discursos disponíveis à sua volta (Burr, 1995; Shotter e Gergen, 1989), como acontece com o discurso do gênero. Sendo o conhecimento aquilo que concordamos ser considerado verdade num determinado contexto de relações sociais, é precisamente nesse processo de acordo que é criada a realidade de determinado fenômeno. $\mathrm{O}$ gênero não é um fenômeno que existe dentro dos indivíduos, pronto a ser descoberto e medido pelos cientistas sociais. Pelo contrário, o gênero é um acordo que existe nas interações sociais: é precisamente aquilo que concordamos que seja (Hare-Mustin e Marecek, 1990; Unger, 1990). Em maior ou menor grau, tanto homens como mulheres, acabam por aceitar as distinções de gênero visíveis a nível estrutural e que se estabelecem ao nível interpessoal, tornando-se tipificados do ponto de vista do gênero, ao assumirem para si próprias, os traços de comportamento generizados e papéis normativos para as pessoas do seu sexo, na sua cultura (Crawford, 1995). Para além desta internalização de traços, comportamentos e papéis, as mulheres internalizam também a sua desvalorização e subordinação (idem, 1995).

O gênero é deste modo, uma invenção das sociedades humanas, uma "peça de imaginação" com facetas múltiplas: construir adultos (homens e mulheres desde a infância), construir os "arranjos sociais" que sustêm as diferenças nas consciências de homens e mulheres (divisão das esferas da vida privada/pública, por exemplo) e a criação de significado, em resumo, criar as estruturas linguísticas que modelam e disciplinam a nossa imaginação (Hare-Mustin e Marecek, 1990a).

Através da interação, negociamos interpretações particulares; isto é, criamos significados. Através da linguagem, através da participação nos rituais da interação social, através do nosso envolvimento ativo com os símbolos e as realidades materiais da vida de todos os dias, nós literalmente criamos aquilo que reconhecemos como real. Um mínimo de compreensão das regras partilhadas e das realidades é necessário para sustentar a comunicação humana e a interação e em última instância as sociedades (Howard e Hollander, 1997, p.35). 
Conforme os autores referem, o gênero é "performativo", podendo dizer-se: "fazer" o gênero (2001b).

O gênero nesta perspectiva é o significado que concordamos imputar a determinada classe de transações entre indivíduos e contextos ambientais. Os fatores que definem uma transação particular como feminina ou masculina não são os sexos dos atores, mas sim os parâmetros situacionais nos quais determinada "performance" ocorre. Ninguém pode ser considerado muito, pouco ou nada, feminino ou masculino; em contextos particulares, as pessoas fazem feminino e noutros possivelmente masculino (West e Zimmerman, 1987). Esta perspectiva pode ser compreendida se pensarmos nas investigações que mostram, por exemplo, mulheres em posições de liderança serem consideradas "masculinas" (Nogueira e Amâncio, 1996), ou pais (homens) sozinhos comportarem-se de forma mais "feminina" que pais casados (Risman, 1987). A disjunção entre sexo e gênero evidenciada nestes dois exemplos ilustra como o gênero não é um traço inerente aos indivíduos, mas sim que, qualidades usualmente vistas como relacionadas com o sexo dos atores, são de fato determinadas pelos contextos. Desta maneira o gênero pode ser concebido apenas como o termo dado a um conjunto de interações comportamento-meio envolvente, que concordamos caracterizar para os membros de um sexo.

Assumindo esta perspectiva podemos questionar como certas interações são consideradas femininas ou masculinas. Segundo Lott (1990) a resposta encontra-se nos contextos diferenciais das experiências. A exposição seletiva de homens e mulheres a contextos generizados elicita comportamentos onde o sexo é compatível com o gênero, reforçando desse modo a percepção que o gênero é sexualmente diferenciado e sexualmente definido. Assim, o processo contínuo de fazer gênero, recria a construção desse mesmo gênero. As mulheres são diferentes, por virtude de serem mulheres, mas paradoxalmente isso não é porque sejam mulheres. As exigências dos contextos sociais constituem os primeiros determinantes do comportamento de forma generizada (idem, 1990) sendo que este processo torna-se tão familiar que acaba por ser experienciado como uma parte da maneira de ser: as pessoas percebem-se como intrinsecamente generizadas porque o gênero inunda completamente as experiências. Esta identificação com a compreensão socialmente construída de gênero guia o comportamento, dirigindo as pessoas a conformar-se com as expectativas generizadas e deste modo a fazer o gênero de uma forma compatível com a sua construção num determinado contexto social. Além disto, a experiência do gênero como um aspecto da identidade interna e como uma qualidade 'natural' das pessoas, corrobora à construção social do gênero como um traço intrapsíquico relacionado com o sexo.

Nesta perspectiva o gênero é também e essencialmente uma questão de poder, sendo possível reconhecer o seu papel na construção social desse mesmo gênero, na sua ativação e na sua autossustentação reprodutiva (Hare-Mustin e Marecek, 1990; Kitzinger, 1994).

Conforme referimos no fim do ponto anterior, as abordagens construcionistas sociais e discursivas enfrentam no momento o debate entre a problemática do assumir de posições realistas ou relativistas, sendo que as grandes críticas apontam para a possibilidade da assunção de um relativismo extremo. Esta mesma situação torna-se de extrema importância quando nos referimos à construção social do gênero, já que este traz consigo a possibilidade (ou impossibilidade) de políticas ativistas feministas. Será que assumir a inexistência de categorias universais impossibilita a defesa da igualdade entre "mulheres" e "homens"? Como defender o feminismo em face a uma pluralidade de identidades?

Tentando refletir sobre esta problemática relativamente ao gênero, Gill (1995) oferece uma alternativa que nos parece ser, de momento, a mais útil aos propósitos de uma psicologia que não se quer convencional nem empiricista e de um feminismo que se pretende emancipatório. Como refere, os cépticos acabaram por reinstalar, paradoxalmente, em vez de desafiar, a noção de pesquisa livre de valores ou neutra, já que uma pesquisa desinteressada (ideal regulador dos relativistas) não parece ser muito distinta dos ideais dos pesquisadores positivistas. Uma posição relativista radical é extremamente problemática para as feministas e para todos aqueles interessados na transformação social, essencialmente porque nega os compromissos políticos na pesquisa (Nogueira, 2001 d). No entanto, a solução não passa por renegar o relativismo e abraçar novamente o realismo, acreditando que é possível obter conhecimento "correto" acerca do mundo social; deve-se evitar que as escolhas recaiam numa polarização entre relativismo e realismo. Segundo a autora é possível levar a cabo uma pesquisa "não neutra" que represente uma espécie de princípio fundador das perspectivas construcionistas e discursivas, uma espécie de relativismo 
sem vergonha de ser político, através do qual as feministas possam fazer das transformações sociais as preocupações explícitas do seu trabalho. Para isso será necessário reinventar um novo vocabulário de valores, com o qual se possam fazer intervenções políticas e sem o qual as feministas ficarão teórica e politicamente paralisadas perante as desigualdades, a injustiça e a opressão.

Para o estabelecimento de uma posição de princípio que represente um novo vocabulário de valores, é necessário por um lado, ter uma atitude relativamente cínica face ao abandono das "meta-narrativas emancipatórias" (como é sugerido pelo movimento pós-modernista em geral e por Lyotard em particular) isto é, evitar cair no impasse que isso acarretaria. A solução parece estar numa articulação entre as ideias pósestruturalistas e pós-modernistas e um projeto político emancipatório, que envolva construir uma posição, partindo das vantagens de ambos os projetos. Para isso, Gill (1995) propõe a reflexividade, como uma posição que o(a) analista deve adotar relativamente às suas posições e interpretações, que por sua vez devem ser explícitas, reconhecidas e reveladas, sendo desta forma o(a) responsável claro pelas suas análises. Com esta proposta pretende-se criticar a aparente reflexividade dos(as) relativistas que, não colocando a perspectiva de valor, a qualidade e possibilidade de qualquer interpretação, acabam por proteger os seus argumentos do criticismo (Nogueira, 2001d). Embora esta forma possa ser adequada por exemplo na literatura, nas ciências sociais essa posição pode ser perigosa, dando crédito a qualquer posição social e qualquer ideologia.

Em síntese, o que é necessário é uma espécie de relativismo ou cepticismo epistemológico que não evite ou faça desaparecer a questão dos valores. Os valores devem ser explicitados e colocados numa arena onde possam ser discutidos, o que implica que haja um repensar da noção de reflexividade. As perspectivas construcionistas sociais e discursivas devem adotar uma reflexibilidade que enfatize a necessidade do(a) analista reconhecer os seus próprios compromissos e de refletir criticamente sobre eles. Procurando explicar e justificar a base para as suas leituras ou análises, a Análise do Discurso torna-se responsável pelas suas interpretações e pelas suas consequências sociais e políticas (Gill, 1995).

Parece-nos que Parker (1992) faz uma leitura interessante desta problemática, quando assume relativamente à Análise do Discurso que o fato desta ter se associado ao "quebrar" das ideias acerca da psicologia moderna implicou tornar-se ao mesmo tempo uma análise problemática, mas igualmente curiosa, útil, perigosa, libertadora e radical.

Do mesmo modo, uma política de articulação feminista implica traçar ou delinear as dinâmicas do poder de diferentes discursos de feminilidade, de investigar as maneiras como a comunidade das mulheres tem sido construída em diferentes contextos, de questionar abertamente a formulação de discursos dominantes sobre as mulheres e evidenciar as alternativas até aí subordinadas (Wetherell, 1995).

No entanto, é vital trabalhar com a ambiguidade e com a ambivalência, reconhecendo que a feminilidade é uma categoria negociável, que toma uma forma particular de identidade dentro de discursos contrastantes e num determinado contexto histórico e cultural. Ao aceitar que não existe "algo" a ser descoberto, a feminilidade deve ser encarada como um método de descrição, não um atributo psicológico. Envolve viver com o conhecimento desconfortável (para alguns), de que os discursos têm múltiplos usos e significados (Potter e Wetherell, 1987), viver com o fato de que nada é simples nem existe um significado inerente, tudo é ambíguo.

A psicologia, como o feminismo, não é unitária, mas representa uma variedade de pontos de vista, métodos e áreas de estudo (Phoenix, 1990). A pesquisa conduzida pelas feministas tem muito a dar à disciplina da psicologia, apesar de não existir uma metodologia feminista que todas as feministas subscrevam. As feministas são distintas e têm diferentes perspectivas do feminismo. Esta diversidade afeta a pesquisa que elas escolhem fazer e os métodos que usam, existindo, no entanto, grandes temas com os quais as feministas parecem concordar (Phoenix, 1990; Wilkinson, 1986) e que normalmente implicam uma avaliação crítica do processo de pesquisa em si mesmo.

Pensamos como Kitzinger (1990) que assume que ser feminista significa ser responsável em face de outras feministas pela psicologia que faz e, como psicóloga, ser responsável face à psicologia pelo seu feminismo. Identificando-se com os dois grupos, pretende oferecer algo de positivo a cada um. Ao feminismo oferecer as análises acerca dos perigos da psicologização que invade o movimento feminista, os criticismos e os conhecimentos (por dentro) de uma disciplina; à psicologia, oferecer as 
análises acerca do papel da retórica dentro das ciências sociais, o assumir de uma perspectiva construcionista crítica como uma alternativa às abordagens positivistas-empiricistas e o conhecimento (por dentro) do feminismo. Apesar de considerar a etiqueta de psicologia feminista como uma contradição nos termos (no sentido de uma ciência neutra e objetiva) ela considera-se "apaixonada" pelo comprometimento quer com o feminismo quer com a psicologia e, a excitação intelectual e o impacto prático da pesquisa, acabam por se situar no espaço criado pela própria contradição.

\section{Conclusão}

O nosso posicionamento situa-se claramente no contexto conceptual e de pesquisa metodológica crítica, na psicologia e nos estudos de gênero em particular. Nesta perspectiva, questionam-se os fatos apresentados pela disciplina como dados adquiridos e evidentes, assumindo-os como construí dos dentro de narrativas especificamente culturais, regimes de verdade, padrões de poder ou formas de ideologia. Apesar de poder haver algum desacordo quanto aos melhores termos a usar e alguma ambiguidade quanto àquilo que uns referem como narrativas e outros como ideologia, os debates têm em si mesmos potencial suficiente para encetar a crítica à reificação (o risco do realismo), à neutralidade relativa aos valores (o risco do relativismo) na psicologia tradicional.

Todos os que partilham de uma forma geral destas abordagens compreendem como a psicologia reproduz, por exemplo, as noções de individualidade e de natureza humana, procurando desconstruir esses discursos e transformá-los, isto é, construir socialmente algo diferente e libertador. Temos a responsabilidade social de proclamar o conhecimento que queremos produzir: de um tipo não opressivo nem regulador, logo que se afaste dos mecanismos de dominação societais (Ibañez, 1996) e que promova a resistência das pessoas contra a dominação. Deve-se promover uma mudança radical; mas, para fazer da Psicologia uma prática libertadora é necessário começar a construí-la em oposição aos pressupostos que fazem dela uma arma de dominação.

Seguindo a sugestão de Potter (2000) parece importante que seja o que for que o novo século implique, a psicologia deve começar por estudar o que as pessoas fazem, isto é, deve-se pesquisar as práticas localizadas das pessoas humanas (Nogueira, 2001 b). Situando-nos numa perspectiva de Psicologia Feminista, concordamos com o autor quando assume que o excitante nestas perspectivas é perceber que, apesar da quantidade de pesquisa psicológica já produzida, virtualmente todo o trabalho está ainda por fazer...

\section{Referências}

Amâncio, L. (1994). Masculino e Feminino. A construção social da diferença. Porto: Edições Afrontamento.

Amâncio, L. (1999). Sexo e Gênero: para uma teoria psicossociológica da relação de dominação entre os sexos. Lição de síntese para efeitos de provas de Agregação. Lisboa: Instituo Superior de Ciência do Trabalho e da Empresa.

Augoustinos, M. \& Walker. I.(1995). Social cognition. An integrated introduction. London: Sage.

Bohan. J. (I 997). Regarding gender. Essencialism, constructionism and feminist psychology. In G. Mary \& S. Davis (Eds.). Toward a new psychology of gender. New York: Routledge.

Brown. S., Pujol. J. \& Curto B. (1998). As one in a Web? Discourse. materiality and the place of ethics. In I. Parker (Ed). Social constructionism, discourse and realism (pp.75-90). London: Sage Publications.

Burman. E. (1990). Differing with deconstruction: a feminist critique. In L Parker \& J. Shotter (Eds.). Deconstructing social psychology. London: Routledge.

Burr. V. (1995). An introduction to social constructionism. London: Routledge.

Burr. V. (1998b). Overview: realism, relativism, social constructionism and discourse. In I. Parker (Ed). Social constructionism, discourse and realism (pp.13-27). London: Sage Publications.

Burr. V. (1998a). Gender and social psychology. London: Routledge.

Burr. V. (2003). Social constructionism. London: Routledge. 
Crawford. M. (1995). Talking difference. On gender and language. London: Sage.

Danziger(1997). The varieties of social construction. Theory and psychology. 7.3. 399-416.

Denzin. N. K. (1995). Symbolic Interactionism. In J. A. Smith, R. Harré \& L. Van Langenhove (Eds.). Rethinking Psychology. London: Sage.

Eagly. A. H. (1994). On comparing women and men. Feminism and Psychology, 4. 4. 513-522.

Farr. R. (1989). The social and collective nature of representations. In J. Forgas \& J. M. Innes (Eds.). Recent advances in social psychology: an international perspective (pp.157-166). North Holland: Elsevier.

Fidalgo, Lurdes (2000). (Re)Construir a maternidade numa perspectiva discursiva. Tese de Doutorado. ISBAS. Universidade do Porto.

Flax, J. (1990). Thinking fragments: psychoanalysis, feminism and postmodernism in the contemporary west. Berkeley: University of California Press.

Foucault. M. (1972). The archaeology of knowledge. London: Tavistock.

Foucault. M. (1979). The history of sexuality. London: Allen Lane.

Fraser, N. \& Nicholson, N. (1990). Social criticism without philosophy: an encounter between feminism and postmodernism. In L. Nicholson (Ed.). Feminism/postmodernism. New York: Routledge.

Gergen, K. J. (1982). Toward transformation in social knowledge. London: Sage.

Gergen, K. J. (1985). The social constructionist movement in modern psychology. American Psychologist, 40, 266-275.

Gergen, K. J. (1992). Lo yo saturado. Barcelona: Paidós.

Gergen, K. J. (1994). Realities and relationships. Soundings in Social construction. Cambridge: Harvard University Press.

Gergen, K. J. (1994a). Exploring the pos-modern. Perils or potencials? American Psychologist, 49, 5, 412-416.
Gergen, M. \& Davis, S. (1997). Toward a new psychology of gender. New York: Routledge.

Gill, R. (1995). Relativism, reflexivity and politics: interrogating discourse analysis from a feminist perspective. In S. Wilkinson \& C. Kitzinger (Eds.). Feminism and discourse: psychological perspectives. London: Sage.

Gilligan, C. (1982). In a different voice. Psychological theory and women's development. Harvard: Harvard University Press.

Halpern, D. F. (1994). Stereotypes, science, censorship and the study of sex differences. Feminism and Psychology, 4, 4, 523-530.

Haraway, D. (1990). A manifesto for Cyborgs: science, technology, and socialist feminism in the 1980. In L.J. Nicholson (Ed.). Feminism/postmodernism. London: Routledge.

Harding, S. (1986). The science question in Feminism. Ithaca and London: Cornell University Press.

Hare-Mustin, R. \& Marecek, J. (1990a). Making difference. Psychology and the construction of gender. New Haven, CT: Yale University Press.

Hare-Mustin, R. \& Marecek, J. (1990b). Gender and the meaning of difference: postmodernism and psychology. In R. Hare-Mustin \& J. Marecek (Eds.). Making difference. Psychology and the construction of gender. New Haven, CT: Yale University Press.

Harré, R. \& Gillet, G. (1994). The discursive mind. London: Sage.

Harré, R. (1995). Discursive psychology. In J. A. Smith, R. Harré \& L. Van Langenhove (Eds.). Rethinking Psychology. London: Sage.

Hartsock, N. (1990). Foucault on Power: a theory for women? In L.Nicholson (Ed.). Feminism/postmodernism. New York: Routledge.

Hepbum, Alexa (2003). An introduction to critical social psychology. London: Sage Publications.

Hoffman, L. (1992). Una postura reflexiva para la terapia familiar. In S. McNamee \& K.J. Gergen (Eds.). La terapia como construcción social (pp.25-44). Barcelona: Paidós. 
Hollway, W. (1984). Gender difference and the production of subjectivity. In J. Henriques, W. Hollway, C. Urwin, C. Venn \& V. Walkerdine (Eds.). Changing the subject: psychology, social regulation and subjectivity. London: Sage.

Hollway, W. (1989). Subjectivity and method inpsychology: gender. meaning and science. London: Sage.

Howard, J. \& Hollander, J. (1997). Gendered situations, gendered selves. London: Sage Publications.

Ibanez, T. (1994). Constructing a representation or representing a construction? Theory and Psychology. 4, 363-381.

Ibanez, T. (1996). Construcionismo social. In Psicologia, discursos e poder. Barcelona: Paidós.

Jesuíno, J. C. (1993). A psicologia social européia. In: Jorge Vale \& M. B. Monteiro (Eds.). A Psicologia Social. Lisboa: Fundação Calouste Gulbenkian.

Kappeli, A. M. (1991). Cenas feministas. In G. Duby \& M. Perrot (Eds.). História das mulheres (v. 4). Porto: Edições Afrontamento.

Kitzinger, C. (1987). The social construction of lesbianism. London: Sage.

Kitzinger, C. (1989). The regulation of lesbian identities: liberal humanism as an ideology of social control. In J. Shotter \& K. J. Gergen (Eds.). Texts of identity. London: Sage.

Kitzinger, C. (1990). The rhetoric of pseudoscience. In I. Parker \& J. Shotter (Eds.). Deconstructing Social Psychology. London: Routledge.

Kitzinger, C. (1994). Sex differences: feminist perspectives. Feminism and Psychology. 4, 4, 501-506.

Lombart, M. (1995). Discurso, orden social y relaciones de poder: una propuesta y su ejemplificación en el discurso sobre la maternidade. Revista de Psicologia Social Aplicada. 5, 1/2, 165-184.

Lott, B. (1990). Dual natures or learned behavior: the challenge to feminist psychology. In R. T. Hare-Mustin \& J. Marecek (Eds.). Making a difference: psychology and the construction of gender (pp.65-101). New Haven, CT: Vale University Press

Lyotard, J. F. (1989). A condição pós-moderna. Viseu: Gradiva.

Nicolson, P.(1995). Feminism and Psychology. In J. A. Smith. R. Harré \& L. Van Langenhove (Eds.). Rethinking psychology. London: Sage.

Nogueira, C. \& Amâncio, L. (1996). Gender and management. Stereotypes and attributions for a successful career. Psicologia. XI. 1, 79-88.

Nogueira, C. (1997). Um novo olhar sobre as relações sociais de Gênero. Perspectiva feminista crítica na Psicologia Social. Tese de Doutorado, Universidade do Minho, Braga.

Nogueira, C. (2001a) Contribuições do construcionismo social a uma nova psicologia do gênero. Cadernos de Pesquisa, 112, 137-154.

Nogueira, C. (2001b). Construcionismo social, discurso e gênero. Psicologia, XV. 1. 43-65.

Nogueira, C. (2001c). Feminismo e discurso do gênero na Psicologia Social. Psicologia \& Sociedade, 13. 1. 107-128.

Nogueira, C. (2001d). Um novo olhar sobre as relações sociais de gênero. Perspectiva feminista crítica na Psicologia Social. Lisboa: Fundação Calouste Gulbenkian.

Parker, I. (1992). Discourse dynamics: critical analysis for social and individual psychology. London: Routledge.

Parker, I. (1998). Social constructionism, discourse and realismo. London: Sage Publications.

Pepitone, A. (1981). Lessons from the history of social psichology. American Psychologist. 36.9, 972-985.

Phoenix, A. (1990). Social research in the context of feminist psychology. In E. Burman (Eds.). Feminists and psychological practice (pp.89103). London: Sage Publications.

Potter, J. \& Wetherell, M. (1987). Discourse and Social Psychology. London: Sage Publications. 
Potter, J. \& Wetherell, M. (1992). Mapping the language of racism. Discourse and legitimation of explotation. London: Harvester Wheatsheap.

Potter, J. (2000). Post-cognitive psychology. Theory \& Psychology, 1, 10, 31-38.

Riger. S. (1992). Epistemological debates, feminist voices: science, social values, and the study of women. American Psychologist, 47, 6, 730740 .

Risman, B. J. (1987). Intimate relationships from a microstructural perspective: men who mother. Gender and Society, 1, 6-32.

Rose, N. (1990). Psychology as a "social" science. In I. Parker \& J. Shotter (Eds.). Deconstructing social psychology. London: Routledge.

Rosenau. P. M. (1992). Post-modernism and the social sciences. Insights, inroads and intrusions. New Jersey: Princeton University Press.

Shotter, J. \& Gergen, K. J. (1989). Texts of identity. London: Sage.

Shotter, J. (1993). Conversational realities. London: Sage.

Shotter, J. (1995). Dialogical psychology. In J. A. Smith, R. Harré \& L. Van Langenhove (Eds.). Rethinking psychology. London: Sage.

Smart, B. (1993). A pós-modernidade. Lisboa: Publicações Europa América.

Soczka, L. (1993). Para uma perspectiva ecológica em Psicologia Social. In J. Vale \& M. B. Monteiro (Eds.). A Psicologia Social. Lisboa: Fundação Calouste Gulbenkian.

Spink, M. J. \& Frezza, R. M. (1999). Práticas discursivas e produção de sentidos: a perspectiva da psicologia social. In M. J. Spink (Org.) Práticas discursivas e produção de sentidos no cotidiano. Aproximações teóricas e metodológicas. São Paulo: Cortez Editora.

Unger, R. K. (1990). Imperfect reflections of reality: psychology constructs gender. In R. Hare-Mustin \& J. Marecek (Eds.). Making difference. Psychology and the construction of gender. New Haven, CT: Yale University Press.
Ussher. J. (2000). Women's madness. In D. Fee (Ed.). Pathology and the postmodern. London: Sage.

West. C. \& Zimmerman, D. H. (1987). Doing gender. Gender and Society. $1,125-151$.

Wetherell, M. (1995). Romantic Discourse and feminist analysis: interrogating investment, power and desire. In S. Wilkinson \& C. Kitzinger (Eds.). Feminism and discourse: psychological perspectives. London: Sage.

Wetherell, M. (1998). Positioning and interpretative repertoires: conversation analysis and post-struturalism in dialogue. Discourse and Society. 9, 3. 387-413.

Wetherell, M. Taylor. S. \& Yates. J. S. (2001). Discourse theory and practice. London: Sage.

Wilkinson S. \& Kitzinger. C. (1995). Feminism and discourse: psychological perspectives. London: Sage.

Wilkinson S. (1986). Sighting possibilities: diversity and commonality in feminist research. In S. Wilkinson (Ed.). Feminist Social Psychology: developing theory and practice. Milton Keynes: Open University Press.

Wilkinson S. (1997). Feminist Psychology. In D. Fox \& L Prilleltensky (Eds.). Critical psychology. An introduction. London: Sage.

Wilkinson S. (1997). Prioritizing the political: feminist psychology. In T. Ibanez \& L. lñiguez (Eds.). Critical social psychology (pp.179-185). London: Sage.

Willig, C. (1998). Social constructionism and revolutionary socialism: a contradiction in terms? In L Parker (Ed.). Social constructionism. discourse and realism (pp.91-104). London: Sage.

Wood. L. A. \& Kroeger, R. O. (2000). Doing Discourse Analysis: Methods for Studying Action in talk and text. London: Sage. 


\section{SOBRE OS AUTORES}

André Parente é pesquisador e professor na Escola de Comunicação da Universidade Federal do Rio de Janeiro, onde criou e coordenou o Núcleo de Tecnologia da Imagem (N-Imagem, 1991) e a Central de Produção Multimídia (CPM, 1998). E-mail: aparente@ acd.ufrj.br

Carmen S. Oliveira é professora titular do Departamento de Psicologia e do Programa de Pós-Graduação da Universidade do Vale do Rio dos Sinos - UNI SINOS — RS. E-mail: carmenoliveira@terra.com.br

Cecília Coimbra é psicóloga, professora adjunta da UFF, pósdoutora em Ciência Política pela USP Fundadora e atual vice-presidente do Grupo Tortura Nunca Mais/RJ. E-mail: gtnm@alternex.com.br

Cristina Di Doménico é professora na Universidad Nacional de Mar del Pia ta, Buenos Aires — Argentina. E-mail: mcdidome@mdp.edu.ar

Glória Diógenes é professora do Programa de Pós-Graduação em Sociologia, pesquisadora do CNPq e coordenadora do Projeto Enxame fazendo arte com galeras de rua. E-mail: gdiogine@ufc.br

Luiz Eduardo Soares é professor da Universidade do Estado do Rio de Janeiro, diretor da MGS-Consultores Associados, ex-Coordenador de Segurança, Justiça e Cidadania do Estado do Rio de Janeiro e ex-Secretário Nacional de Segurança Pública.

Luis Antônio Baptista é professor titular do Departamento de Psicologia e do Programa de Pós-Graduação em Educação da Universidade Federal de Fortaleza - UFF. E-mail: baptista509@ hotmail.com

Lupicínio Iñiguez é professor do Departament de Psicología de la Salut i de Psicología Social da Universitat Autónoma de Barcelona Edifici B 08193 Belaterra (Barcelona). E-mail: lupicinio.iniguez@uab.es. Site: http://antalya.uab.es/liniguez/

Margareth Axt é professora titular da Faculdade de Educação, UFRGS, pesquisadora nos programas de pós-graduação em Educação (PPGEDU) e em Informática na Educação (PPGIE), coordenadora do Laboratório de Estudos em Linguagem Interação e Cognição (LELICIUFRGS).E-mail: maaxt@ufrgs.com.br
Maria da Conceição Nogueira é professora do Departamento de Psicologia, Instituto de Educação e Psicologia, Campus de Gualtar, Universidade do Minho, Portugal. E-mail: cnog@iep.uminho.pt

Maria da Graça Corrêa Jacques é psicóloga, professora do PósGraduação em Psicologia Social e Institucional da Universidade Federal do Rio Grande do Sul _ UFRGS. E-mail: fijacques@ @erra.com.br

Neuza Maria de Fátima Guareschi é professora do Programa de PósGraduação em Psicologia, Faculdade de Psicologia da Pontifícia Universidade Católica do Rio Grande do Sul - PUCRS. E-mail: nmguares@pucrs.br

Paulo Peixoto de Albuquerque é professor titular do Programa de Pós-Graduação em Ciências Sociais Aplicadas da Universidade do Vale do Rio dos Sinos dentro das linhas de pesquisa: Trabalho: transformações e alternativas e Associativismo e cooperativismo. E-mail: albuq@poa.unisinos.br

Pedrinho A. Guareschi é professor titular da PUCRS, pesquisador do CNPq no Programa de Pós-Graduação da Faculdade de Psicologia. E-mail: guareschi@pucrs.br

Peter Spink é membro do Núcleo de Organização e Ação Social da PUC-SP, Programa Gestão Pública e Cidadania FGV-EAESP. E-mail: spink@igvsp.br

Rosalina Carvalho da Silva é professora no Departamento de Psicologia e Educação da FFCL - Ribeirão Preto Campus da USP. Email: rcdsilva@ffclrp.usp.br

Virgínia Kastrop é doutora em Psicologia e professorado Programa de Pós-Graduação em Psicologia da Universidade Federal do Rio de Janeiro. E-mail: vkastrup@ar.microlink.com.br 